THE DEVELOPMENT OF AN INTEGRATED DECISION MODEL

FOR PUBLIC INVESTMENT PROJECTS IN THAILAND

Pintip Vajarothai 


\title{
THE DEVELOPMENT OF AN INTEGRATED DECISION MODEL
}

FOR PUBLIC INVESTMENT PROJECTS IN THAILAND

\section{DISSERTATION}

\author{
to obtain \\ the degree of doctor at the University of Twente, \\ on the authority of the rector magnificus, \\ prof.dr. T.T.M. Palstra,
}

on account of the decision of the graduation committee,

to be publicly defended

on Wednesday the $3^{\text {rd }}$ of July 2019 at 14.45 hours

by

\section{Pintip Vajarothai}

born on the 22 August 1979

in Bangkok, Thailand 
This dissertation has been approved by:

Promoter: prof. dr. ir. J.I.M. Halman

Co-promoter: dr. S.H.S. Al-jibouri

This research is supported by the Hydro-Informatics Institute under the Ministry of Science and Technology and the Royal Thai Government Scholarship.

Cover design and lay-out: Pintip Vajarothai Printed by: Ipskamp Printing ISBN: 978-90-365-4804-5 DOI: $10.3990 / 1.9789036548045$

Copyright () 2019 Enschede, The Netherlands.

All rights reserved. If one refers to the author, title and year of publication, every part of this thesis may be used for non-commercial purposes, free of charge and free of copy rights without the written permission of the author. For commercial purposes, written permission of the author is required. 


\section{GRADUATION COMMITTEE:}

\section{Chairman/secretary}

prof. dr. G.P.M.R. Dewult University of Twente

Promoter prof. dr. ir. J.I.M. Halman University of Twente

Co-promoter dr. S.H.S. Al-jibouri University of Twente

\section{Committee members}

prof. dr. K. Pfeffer

prof. dr. ir. L. Volker

prof. dr. R. Kabir

prof. dr. ir. M.J.C.M. Hertogh

dr. Chotchai Charoenngam
University of Twente

University of Twente

University of Twente

Delft University of Technology

Asian Institute of Technology 
"Nowadays, Thailand is full of resources, including natural resources and human resources, which can be used to strengthen the prosperity and stability of the country.

Most importantly, we need to know how to wisely use these resources.

This means the resources would not be wasted on useless spending or less important things, but carefully and prudently spent in a thoughtful way.

Therefore, we should consider principles and rationales with integrity which focus on the true benefits for the country presently and in the long term."

Royal Guidance of His Majesty the King Bhumibol Adulyadej (King Rama IX)

on 5 December 1986

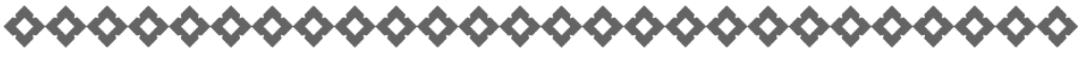

“ทุกวันนี้ ประเทศไทยยังมีทรัพยากรพร้อมบูล ทั้งทรัพยากรธรรมชาติและทรัพยากรบุดดล ซึ่งเราสามารกนำมาใช้เสริมสร้างดวามอุดมสมบูรณ์ และสสกียรกาพอันกาวรของบ้านเมืองได้เป็นอย่างดี ข้อสำดัญ เราต้องรู้วักไช้ทรัพยากรนั้นอย่างฉลาด ดือไม่นำมาทุ่บเทไช้ไห้เปลืองไปโดยไร้ประโยชน์ หรือได้ประโยชน์ไม่ดุ้มค่า

หากแต่การระมัดระวังใช้ด้วยดวามประหยัดรอบดอบ ประกอบด้วยดวามคิดพิจารณาตามหลักวิชา เหตุผล และดวามกูกต้องเหมาะสม โดยมุ่งกี่งประโยชน์แท้จริงที่จะเกิดแก่ประเทศชาติ ทั้งในปัจจุบันและอนาดตอันยีนยาว"

พธะราชดำรัส ของพระบาทสมเด็จพระเจ้าอยู่ห้วรัชกาลที่ $\propto$ ในการเสด็จออกมหาสมาดม

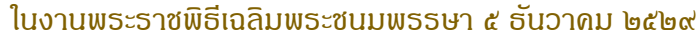




\section{Table of Contents}

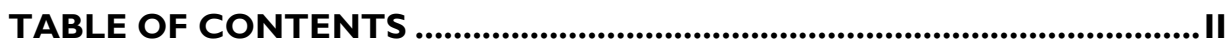

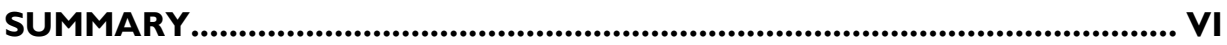

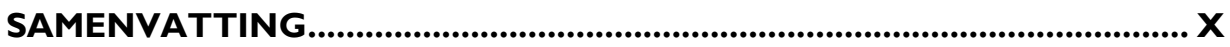

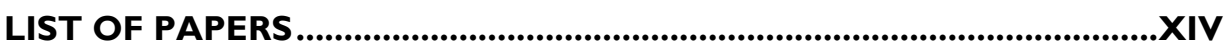

CHAPTER I

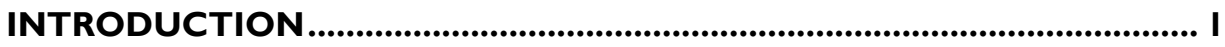

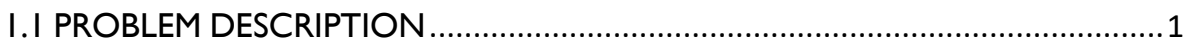

I.2 OBJECTIVES AND RESEARCH QUESTIONS .................................................. 4

I.3 RESEARCH DESIGN AND METHODOLOGY ..................................................

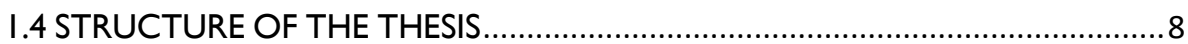

CHAPTER 2

THEORIES AND TECHNIQUES ON PROJECT EVALUATION .............. I 3

2.I FUNDAMENTALS OF PROJECT EVALUATION ........................................... 13

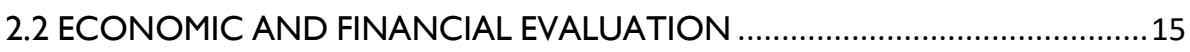

2.3 ECONOMIC EVALUATION METHODS ........................................................ 16

2.3.I Crude investment criteria......................................................................... 17

2.3.2 Discounted Cash Flow techniques (DCF) ....................................................20

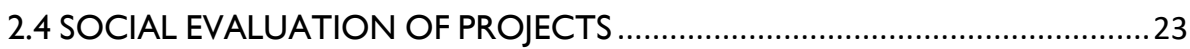

2.4.I Cost-benefit analysis and the social discount rate for projects .......................... 25

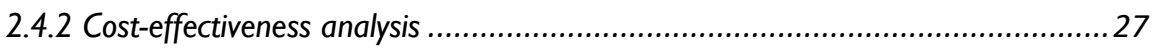

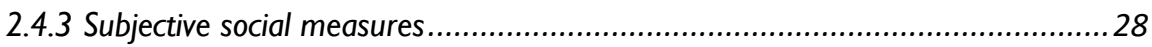

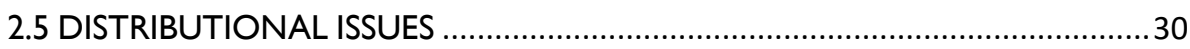

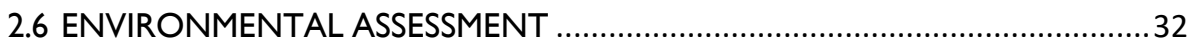

2.7 PUBLIC PARTICIPATION AND INVOLVEMENT ............................................ 33

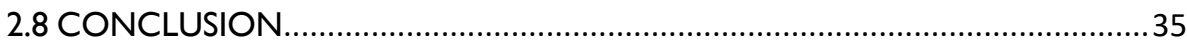

\section{CHAPTER 3}

THEORETICAL BACKGROUND ON DECISION-MAKING ...................... 39

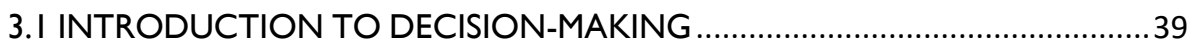

3.2 APPROACHES TO DECISION-MAKING ................................................... 41

3.2.I Behavioural decision-making .................................................................. 41

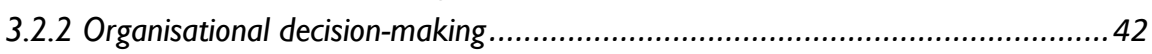

3.2.3 Multiple-criteria/attributes decision-making ............................................. 42

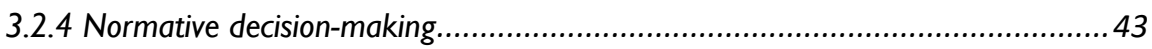

3.3DECISION-MAKING PROCESS ............................................................ 44 


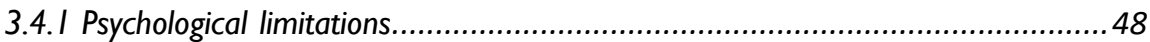

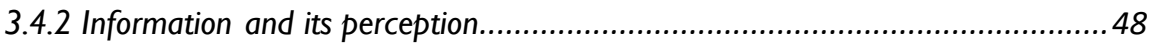

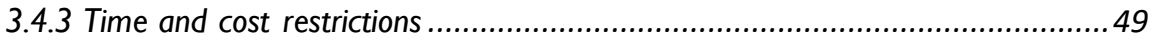

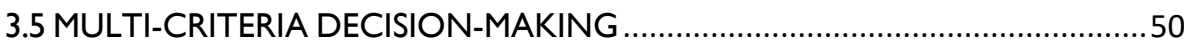

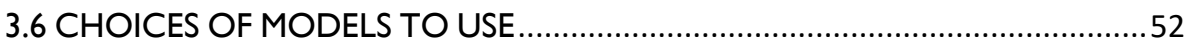

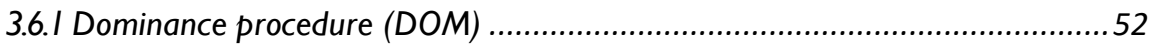

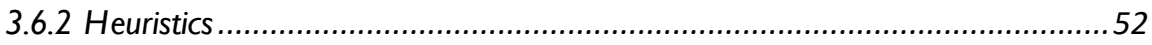

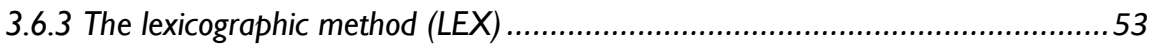

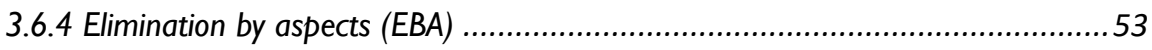

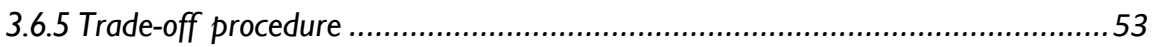

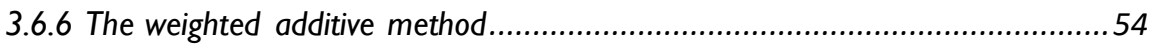

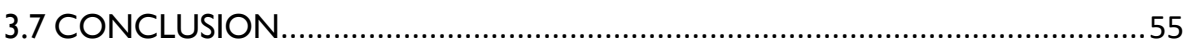

\section{CHAPTER 4}

PUBLIC INVESTMENT PROJECTS EVALUATION AND SELECTION IN

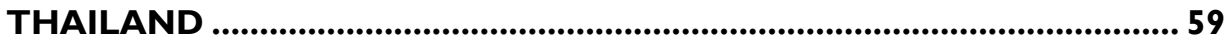

4.I SELECTION PROCESS FOR PUBLIC INVESTMENT PROJECTS IN

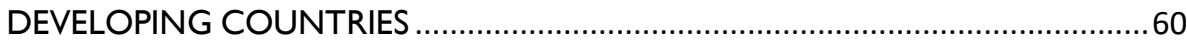

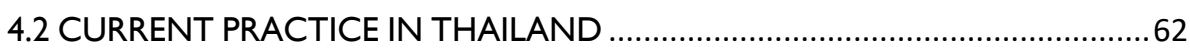

4.2.I Public investment project selection procedure ..............................................62

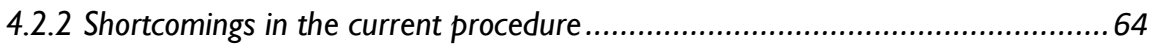

4.3 REQUIREMENTS FOR IMPORTANT CRITERIA ..............................................66

4.3.I Collection of criteria for public investment decision........................................68

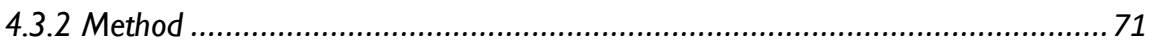

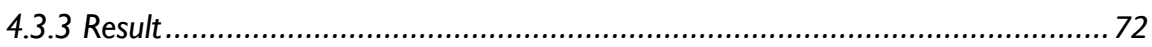

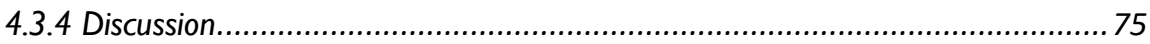

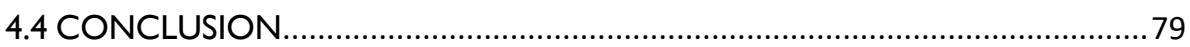

\section{CHAPTER 5}

AN INTEGRATED DECISION MODEL AND METHODOLOGY ........... 83

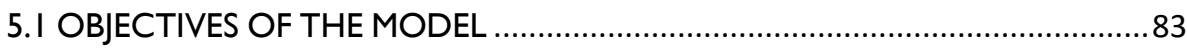

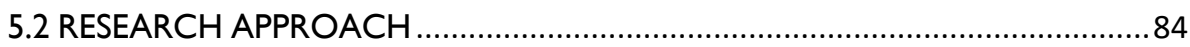

5.2.I Analysis of the problems and initial responses ............................................. 84

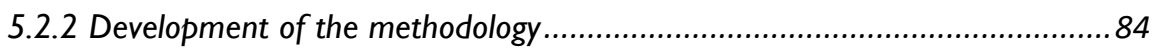

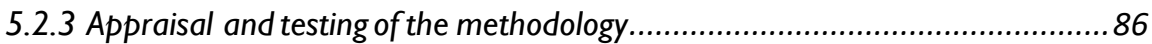

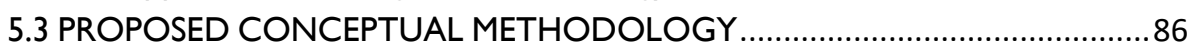

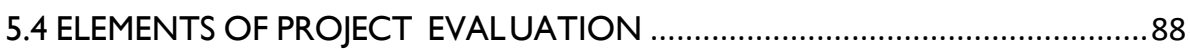

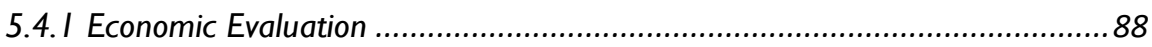

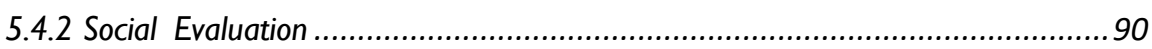

5.4.3 Environmental Impact Evaluation ........................................................... 94 
5.4.4 Project support .95

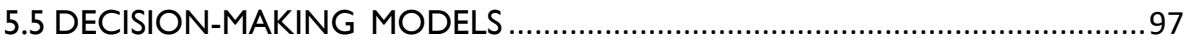

5.6 STRUCTURE OF THE METHODOLOGY ............................................... 102

5.7 REQUIRED MODEL INFORMATION ….................................................... 105

\section{CHAPTER 6}

APPLICATIONS OF THE METHODOLOGY AND DECISION MODEL

6.I CASE I: AN IRRIgAtion DEVELOPMENT PROJECT IN YOM River Basin, ThaILAND

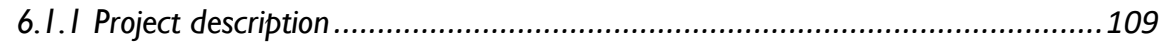

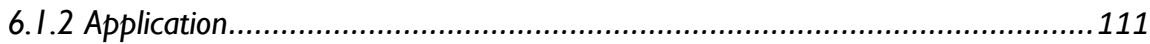

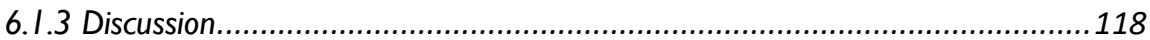

6.2 CASE 2: A Bypass RoAd PRoject IN Chachoengsao Province, ThaIland...121

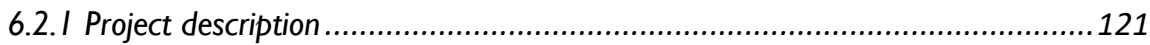

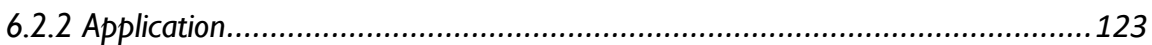

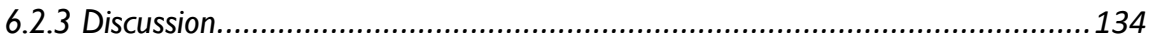

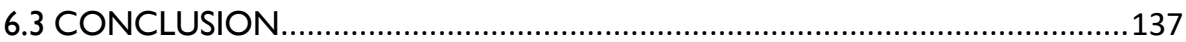

\section{CHAPTER 7}

ASSESSMENT AND TESTING ..................................................... I 43

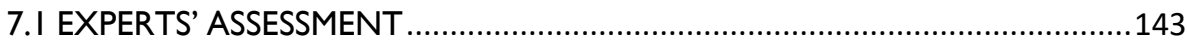

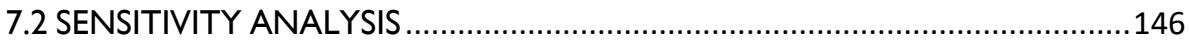

7.2.I Sensitivity analysis methodology ............................................................. 147

7.2.2 Testing case I: An Irrigation Development Project in Yom River Basin............. 148

7.2.3 Testing case 2: A Bypass Road Project in Chachoengsao Province ...................155

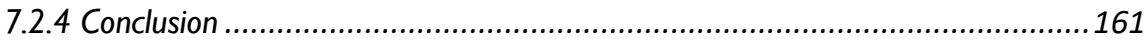

\section{CHAPTER 8}

DISCUSSION AND CONCLUSION.......................................................... I 65

8.I SUMMARY OF RESULTS AND GENERAL DISCUSSION .............................165

8.I.I Theoretical background on project evaluation and decision-making.................166

8.I.2 The current state and challenges of the evaluation and selection of public investment projects in Thailand......................................................................... 168

8.I.3 The development of an integrated decision model for evaluation and selection of public investment projects ........................................................................... 171

8.I.4 Effectiveness of the decision model and robustness of the selected choice....... 174

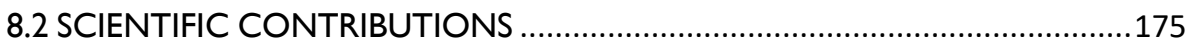

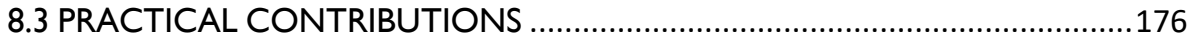

8.4 LIMITATIONS AND SUGGESTIONS FOR FUTURE RESEARCH ...................176

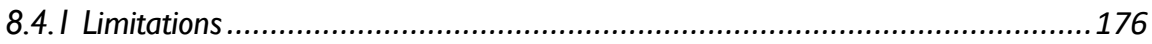

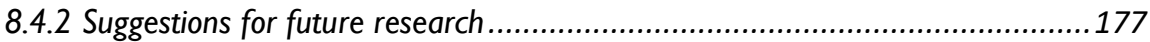


APPENDIX: A SCIENTIFIC JOURNAL PAPER ..................................... 181

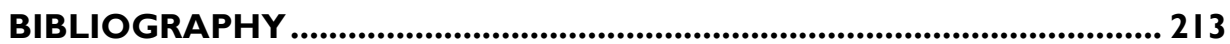

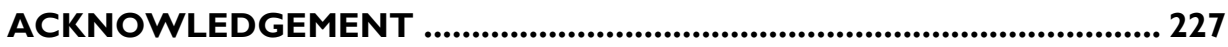

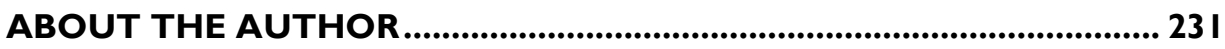




\section{Summary}

In many developing or low-income countries, governments initiate numerous investment projects to improve the conditions and the quality of life of their respective populations. However, despite all these efforts, no considerable improvements in local conditions or in the quality of life of the communities are achieved. Research shows, that in many cases, such failures are caused by the way public investment projects are evaluated and selected.

In this $\mathrm{PhD}$ thesis, Thailand is chosen as a representative case to study the evaluation and selection of public investment projects. Experiences in Thailand show that despite the numerous investments that are made in public projects, local communities often do not benefit from these investments. The comparison between investment projects in Thailand, is merely based on a one-sided economic measurement, ignoring other important aspects such as the societal and environmental impact of an investment project. Research also indicates that Thailand scores very low, even among middle and low-income countries, in terms of the transparency of the selection procedure of public investment projects. The main research question that has been formulated therefore for this $\mathrm{PhD}$ thesis is:

How to develop an integrated model that can be used to improve the evaluation and selection process for public investment projects?

To answer this main research question, the following four sub-questions were formulated:

I) What approaches and techniques are available in the field of project evaluation and decision-making in the public sector?

2) What is the current state of the public investment project selection process in Thailand?

3) How to incorporate the relevant concepts and techniques from different disciplines into one integrated model to improve project evaluation and selection processes?

4) How to validate and test the correctness, efficiency and adaptability of the developed model?

To answer these sub-research questions, the research project was divided into four steps. 
First, a literature review was conducted about project evaluation and decisionmaking approaches and techniques that can possibly be applied for evaluating and selecting public investment projects. With respect to economic methods, especially the discounted cash flow techniques (DCF), i.e. the NPV, IRR and B/C ratio techniques, seem popular when policy makers want to pursue their investment objectives. A considerable amount of work shows a trend of economic evaluations that seem to be shifting towards the NPV technique. However, in cases where benefits cannot be measured in a monetary unit, the CEA (cost-effectiveness analysis) is seen as a more appropriate economic technique to capture the overall benefits.

Besides economic methods, also non-economic approaches were reviewed. Non-economic methods are needed to measure the impact of an investment on society, environment and public participation. Although the attempt to include social, environmental and stakeholders and public participation aspects into project assessments has made significant progress over the last few decades, the expectations on how these aspects will influence the decision-making process are still causing a lot of debate. The review also shows that although the decision making processes in literature are well structured, organising the process of evaluation and selection can have its challenges in practice. Most public investment decisions are complex and the selection of investment projects often also involves conflicting values and criteria. Due to this inherent complexity, it will be difficult for a human's mind to deduce a rational way of analysis when the selection of individual projects is no longer based on a single criterion but depends on multiple criteria/attributes. The theoretical review and evidences in practice indicate the need, therefore, to use multiple criteria decision making/analysis methods (MCDM/MCDA). These methods have shown their usefulness in helping decision makers to improve the quality of their decision and to make the evaluation and selection process more explicit.

The literature review also reveals a lack of consensus about which methods and methodologies are best appropriated to be used for any decision situation. The selection of an appropriate evaluation and decision-making method is not an easy task. Moreover, there exists a lack of interaction and integration between methods from different disciplines. Different issues have different importance to experts in different areas. The literature review and the diagnosed problems in practice raised the question how to include, measure and integrate the required aspects and criteria by the use of appropriate economic and non- 
economic evaluation methods to improve the process of evaluation and selection of public investment projects in Thailand.

Second, a thorough analysis was conducted to investigate the main shortcomings and possible improvements in the current state of evaluating and selecting public investment projects in Thailand. One of the main findings is the absence of standard guidelines or a general applied methodology to evaluate the benefits of public investment projects. The findings also show that the comparison between alternative projects is one-sided based on economic measurements and overlooks important other investment impacts that investment projects may have on e.g. society and the environment. Moreover, in most cases, the impact assessment of a project is carried out without a meaningul public participation. The identified findings in the process of evaluation and selection of public investment projects in Thailand have led to a process to search for possible solutions to improve the process of evaluation and selection of public investment projects in Thailand. This search process resulted into the identification of eleven criteria in five aspects of public investment evaluation, selected by 52 evaluators and experts. Among those eleven criteria and five aspects, seven criteria and four aspects (i.e. economic, social, environmental and long term support) appeared to be suitable to be used in the evaluation and selection phase of public investment projects.

Third, the results of the literature review and the diagnosed shortcomings in evaluation and selection of public investment projects in Thailand and the input given by the 52 evaluators and experts formed the basis for the development of an Integrated Decision Model (IDM) for evaluation and selection of public investment projects. The IDM integrates various evaluation and decision-making techniques into one decision model which is suitable for addressing economic, social, environmental and long-term project support attributes. The entire methodology was tested on its adaptability and usefulness in two real project cases in Thailand. Based on the application of the IDM in these two real cases, the conclusion seems justified that the proposed methodology is not only appropriate to be applied in the process of evaluation and selection of public investment projects in Thailand, but also, that it provides a better understanding of the evaluation results of the projects.

Fourth, the developed IDM was assessed in terms of its ease of use, suitability and adaptability. IDM were presented to a total number of 40 experts from relevant organizations in Thailand. Also a questionnaire was sent by e-mail to 
these experts to request for feedback. $75 \%$ of the experts provided their feedback. The assessments by the experts indicate that the proposed methodology is easy to follow and apply. The experts further have unanimously indicated that the IDM covers all the important factors and variables required for evaluating and selecting public investment projects in Thailand. They also agreed that applying the proposed IDM represents a substantial improvement on the current procedure because it provides more insight on how the alternatives impact on social and environmental aspects. Hence IDM provides better information for a more informed decision for the most effective solution. A final step in the research process has been the conduction of a sensitivity analysis. The sensitivity analysis was conducted on the weights included in the IDM to test the robustness of a selected project choice. The testing indicates that the attributes' scores and weights effect the decision result. Small changes on some attribute' weights can change the final scores and the original ranking of alternatives. This provides a decision maker and evaluator a better insight about the robustness of the choices that are made. 


\section{Samenvatting}

In veel ontwikkelingslanden initiëren overheden allerlei investeringsprojecten om de leefbaarheid te verbeteren en de levensstandaard te verhogen. Ondanks al die inspanningen blijken de leefomstandigheden van lokale gemeenschappen echter nauwelijks te verbeteren. Onderzoek toont aan dat dat veelal wordt veroorzaakt door de wijze waarop publieke investeringsprojecten worden beoordeeld en geselecteerd.

Dit proefschrift gebruikt Thailand als een representatieve casestudie om de beoordeling en selectie van publieke investeringsprojecten te onderzoeken. Uit ervaringen in Thailand blijkt dat lokale gemeenschappen meestal niet profiteren van publieke investeringsprojecten, ondanks de veelvoud aan dat soort projecten. Afwegingen tussen verschillende investeringsprojecten in Thailand zijn meestal enkel gebaseerd op economische inschattingen en zien daarbij andere belangrijke aspecten over het hoofd, zoals de impact op de maatschappij of het milieu. Onderzoek laat verder zien dat Thailand erg laag scoort in termen van transparantie van het selectieproces voor publieke investeringsprojecten, zelfs onder de midden- en lage-inkomenslanden. De hoofdvraag van dit PhDonderzoek is daarom:

Hoe kan een geïntegreerd model worden ontwikkeld dat gebruikt kan worden om het beoordelings- en selectieproces voor publieke investeringsprojecten te verbeteren?

Om deze hoofdvraag te beantwoorden, zijn de volgende deelvragen geformuleerd:

I) Welke methoden en technieken zijn beschikbaar voor het beoordelen van projecten en de besluitvorming in de publieke sector?

2) Hoe is het huidige selectieproces voor publieke investeringsprojecten in Thailand vormgegeven?

3) Hoe kunnen relevante concepten en technieken van verschillende disciplines worden geïntegreerd in een model ter verbetering van beoordelings- en selectieprocessen van investeringsprojecten?

4) Hoe kan het ontwikkelde model worden gevalideerd en hoe kan de juistheid, efficiëntie en aanpasbaarheid worden getest?

Om deze vragen te beantwoorden, bestaat dit onderzoeksproject uit vier stappen. 
Ten eerste is er een literatuuronderzoek uitgevoerd naar methoden en technieken die gebruikt kunnen worden in de beoordelings- en besluitvormingsprocessen voor publieke investeringsprojecten. Voor wat betreft economische methoden, gebruiken beleidsmakers vooral de verdisconteerde geldstroom-technieken (discounted cash flow, DCF), zoals de Netto Contante Waarde (Net Present Value, NPV), interne-opbrengstvoet (internal rate of return, IRR) en kosten-batenverhouding (cost-benefit ratio). Een aanzienlijk aantal onderzoeken laat een toename zien in de toepassing van de NPV-techniek. Wanneer de te verwachte voordelen niet in geld kunnen worden uitgedrukt, wordt de kosteneffectiviteitsanalyse (cost-effectiveness analysis, CEA) echter als geschiktere techniek gezien om de algehele effecten te beoordelen.

Naast economische methoden zijn ook niet-economische methoden onderzocht. Niet-economische methoden zijn nodig om de impact van een investering te meten op de maatschappij, het milieu en publieke participatie. Hoewel in de afgelopen decennia grote vooruitgang is geboekt ten aanzien van de integratie van sociale, milieutechnische en participatie-aspecten bij projectbeoordelingen, is er nog veel onduidelijk over hoe die aspecten het besluitvormingsproces beïnvloeden. In de literatuur zijn besluitvormingsprocessen daarbij vaak systematisch gestructureerd, maar in de praktijk zijn er juist allerlei uitdagingen bij het organiseren van projectbeoordelingen en -selectie. De meeste besluiten over publieke investeringen zijn complex en bij de selectie van investeringsprojecten spelen vaak conflicterende belangen en criteria. Vanwege deze inherente complexiteit is het lastig voor het menselijk brein om een rationele analyse te maken wanneer de selectie van individuele projecten niet meer gebaseerd is op een enkel criterium maar afhankelijk is van meerdere criteria/attributen. De theorie en de praktijk wijzen dus op een noodzaak om methoden te gebruiken voor multicriteria-besluitvorming en -analyse (multiple criteria decision making/analysis, $M C D M / M C D A)$. Die methoden zijn bruikbaar gebleken bij het verbeteren van de kwaliteit van de besluiten die beleidsmakers maken en bij het explicieter maken van het beoordelings- en selectieproces.

Het literatuuronderzoek heeft ook een gebrek aan consensus blootgelegd over de methoden en methodologieën die het best kunnen worden toegepast in verschillende situaties waarin een besluit moet worden genomen. De keuze voor een geschikte beoordelings- en besluitvormingsmethode is geen eenvoudige taak. Er bestaat bovendien een gebrek aan interactie en integratie tussen de methoden die gebruikt worden door diverse disciplines. De mate van 
belangrijkheid van bepaalde issues wordt door experts van verschillende disciplines vaak op eveneens verschillende wijze beoordeeld. Het literatuuronderzoek en de gediagnosticeerde problemen in de praktijk roepen zo de vraag op hoe noodzakelijke aspecten en criteria kunnen worden meegenomen, gemeten en geïntegreerd in geschikte economische en nieteconomische methoden in de beoordelings- en selectieprocessen voor publieke investeringsprojecten in Thailand.

Ten tweede is er een diepgaande analyse uitgevoerd naar de tekortkomingen van en mogelijke verbeteringen voor het huidige beoordelings- en selectieproces voor publieke investeringsprojecten in Thailand. Een van de hoofdbevindingen is dat er geen standaard richtlijnen of algemeen toepasbare methodologieën zijn om de te verwachte voordelen van publieke investeringsprojecten te beoordelen. Het blijkt ook dat alternatieve projecten veelal enkel worden vergeleken met economische meetmethodes en dat daarbij andere mogelijk belangrijke effecten, bijvoorbeeld op de maatschappij of het milieu, over het hoofd worden gezien. In de meeste gevallen vindt de beoordeling van projecteffecten bovendien plaats zonder dat de bevolking daarbij wordt betrokken. Deze inzichten in het beoordelings- en selectieproces voor publieke investeringsprojecten in Thailand hebben vervolgens tot een zoektocht geleid naar mogelijkheden om dat proces te verbeteren. Die zoektocht heeft geresulteerd in de identificatie van elf criteria en vijf aspecten voor de beoordeling van publieke investeringsprojecten, welke geselecteerd zijn door 52 beoordelaars en experts. Van deze elf criteria en vijf aspecten bleken zeven criteria en vier aspecten (namelijk: economisch, sociaal, milieutechnisch en langetermijnondersteuning) geschikt voor gebruik in de beoordeling- en selectiefase voor publieke investeringsprojecten.

Ten derde bieden het literatuuronderzoek, de geïdentificeerde tekortkomingen van de manier van beoordeling en selectie van publieke investeringsprojecten in Thailand en de input van de 52 beoordelaars en experts een basis voor het ontwikkelen van een geïntegreerd besluitvormingsmodel (Integrated Decision Model, IDM) voor het beoordelen en selecteren van publieke investeringsprojecten. Het IDM integreert verscheidene beoordelings- en besluitvormingstechnieken in één besluitvormingsmodel geschikt voor economische, sociale, milieutechnische en langetermijnondersteuningsaspecten. Deze gehele methodologie is getest op aanpasbaarheid en geschiktheid in twee projectcases in Thailand. Op basis van de toepassing van het IDM in deze twee cases, lijkt het erop dat de conclusie wordt ondersteund 
dat de voorgestelde methodologie niet alleen geschikt is voor het beoordelingsen selectieproces voor publieke investeringsprojecten in Thailand, maar dat het ook een beter inzicht biedt in de beoordelingsresultaten van die projecten.

Ten vierde is het ontwikkelde IDM beoordeeld aan de hand van zijn bruikbaarheid, geschiktheid en aanpasbaarheid. Het IDM is gepresenteerd aan een totaal van 40 experts in relevante organisaties in Thailand. Ook is er een vragenlijst naar hen rondgestuurd per e-mail om naar hun feedback te vragen. $75 \%$ van de experts heeft zijn/haar feedback gegeven. Die feedback toont aan dat de ontwikkelde methodologie eenvoudig is te volgen en toe te passen. De experts hebben verder unaniem aangegeven dat het IDM alle belangrijke factoren en variabelen omvat voor het beoordelen en selecteren van publieke investeringsprojecten in Thailand. Zij zijn het er verder over eens dat het toepassen van het voorgestelde IDM een substantiële verbetering betekent ten opzichte van het huidige proces aangezien het meer inzicht biedt in hoe de verschillende alternatieven scoren op sociale en milieutechnische aspecten. Het IDM biedt dus betere informatie voor een beter onderbouwd besluit over de meest effectieve oplossing. Een laatste stap in het onderzoek is een gevoeligheidsanalyse geweest. Die analyse is uitgevoerd voor de relatieve gewichten van de criteria in het IDM om zo de robuustheid van het besluitvormingsproces te testen. Dat toonde aan dat de scores van attributen en gewichten de uitkomst van het besluit beïnvloeden. Kleine wijzigingen van sommige attributen en gewichten kunnen tot een wijziging in de uiteindelijke scores en de voorkeursrangorde van de projectalternatieven leiden. Dit biedt de besluitvormer en de beoordelaar een beter inzicht in de robuustheid van de keuzes die gemaakt zijn. 


\section{List of papers}

In addition to the content of this $\mathrm{PhD}$ thesis, an appendix is included with a paper that was submitted to an international double-blind reviewed scientific journal. This is:

Appendix: $\quad$ Vajarothai, Pintip, Al-jibouri, Saad and Halman, Johannes I.M. An integrated decision model for public investment project selection in developing countries: A case study in Thailand. Submitted for publication in Impact Assessment and Project Appraisal.

\section{Additional publications}

Vajarothai, P., Al-jibouri, S. \& Halman, J.I.M. (20I5). A conceptual decision model for an investment project appraisal and selection procedure. Presented in 13th International Conference on Science and Engineering Research, December 16-17, 2015, Bangkok, Thailand.

Vajarothai, P., Al-jibouri, S. \& Halman, J.I.M. (2017). Selection of social and sustainability criteria for public investment project evaluation in developing countries. In World Academy of Science, Engineering and Technology Conference Proceedings, Vol.19, 28-29 May, 2017, Tokyo, Japan. pp.4I56-4I63. 


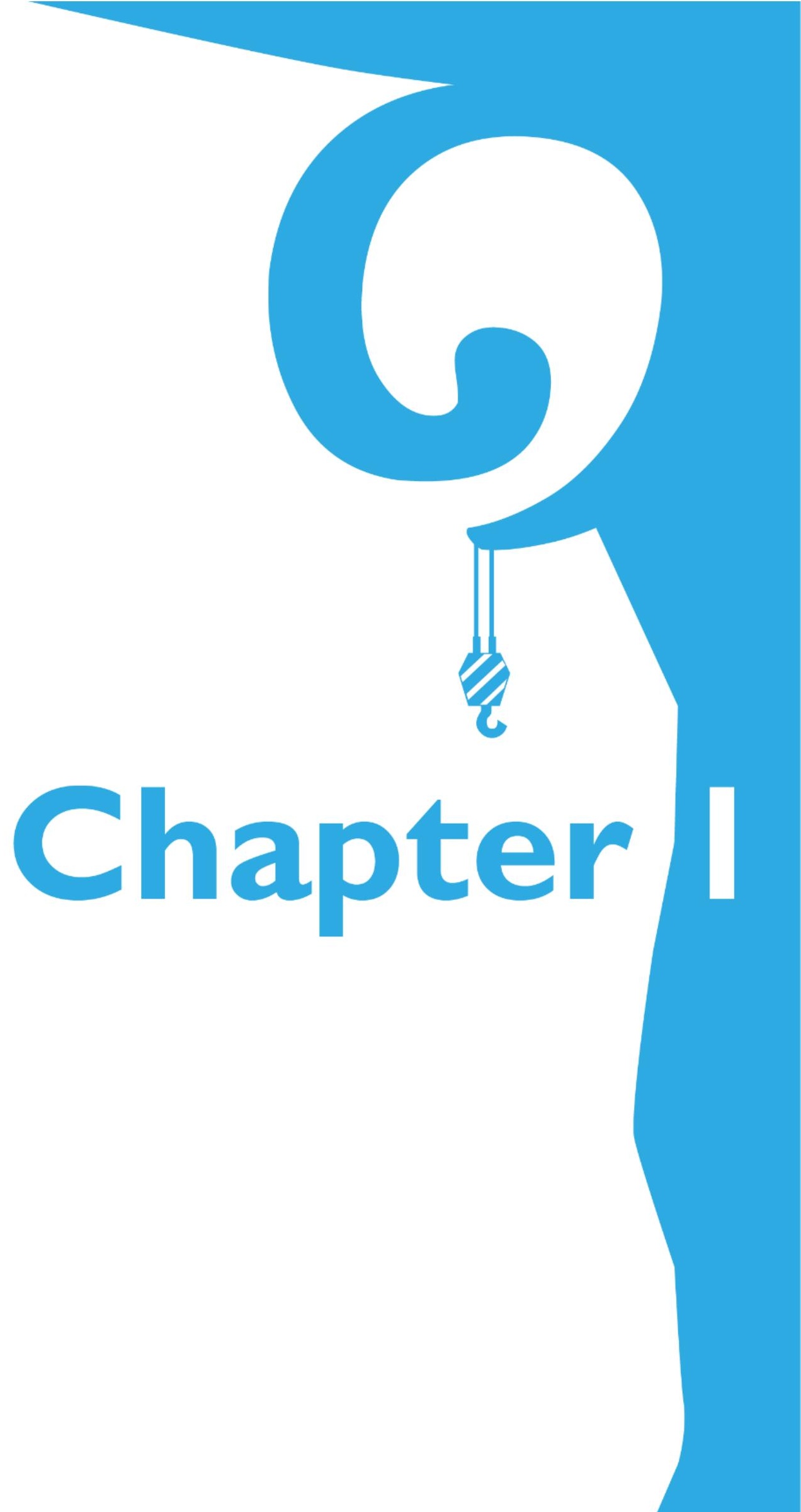




\section{INTRODUCTION}

This chapter provides an overview of the research work and how it was carried out throughout the several stages of the study. The following section first presents important problems related to investment decisions in public investment projects. The problems addressed in section I.I were the principal motivation to start this $\mathrm{PhD}$ thesis and gave rise to main objective of this study: developing an integrated model that can be used to improve the current evaluation and selection process for public investment projects in Thailand. Section 1.2. describes the main research question and corresponding subquestions and section 1.3. explains the research design and research approach followed. This chapter concludes by providing an overview of the various chapters included in this $\mathrm{PhD}$ thesis.

\section{I.I PROBLEM DESCRIPTION}

Public investment projects are often defined as solutions to allocate public resources in order to achieve economic growth and to help meet a country's social development goals (Jó \& Barry 2008). They involve investments in the construction of infrastructure (e.g. roads, reservoirs, energy supply and buildings) and the acquisition of equipment and technology (e.g. defence, information and communication technology). These projects usually go through a process of evaluation of alternatives to find the most suitable and effective solution to deal with the original investment problems and needs. Hence, the process also involves decision-making, an essential part of the whole investment process, to decide on the most suitable option among various alternatives. The disciplines of project evaluation and decision-making are evolving, with critical implications in many areas of study. Whereas many strides have been made towards the theoretical development of these disciplines, their more practical aspects remain unstructured and lack a strong foundation (Belton \& Stewart 2002). The process has many problems, especially in developing countries, as indicated in published work and practice. In many developing or low-income countries, plans are drawn up by the government and, accordingly, numerous investment projects are initiated every year to improve their population's conditions and quality of life. However, despite all these efforts, no considerable improvements in local conditions or in the quality of life of the communities are achieved (Fang \& Sakellariou 2013; Jó \& Barry 2008; Reardon \& Vosti 1995). In many cases, such failures are caused by the way in which public investment 
projects are evaluated and selected. A major challenge is related to how the evaluation and selection process, which is part of the decision-making process, is designed to guide the decision maker through the process. Research by Shiferaw et al. (2012) indicates that the process of selecting public investment projects in developing countries is often unstructured and inconsistent, and that, in most cases, there appears to be no system in place to identify the public's current needs and demands in order to prioritise projects. In these countries, the ultimate decision often ignores society's priorities and is identified without any clear degree of project prioritisation.

Most of the investment decisions of the past - and to a large extent of the present - are focused on selecting projects that produce the highest financial returns. It is believed that investment projects with a high financial rating will increase GDP (Gross Domestic Product per capita) and consequently improve the nation's overall future prosperity. Though this is true in every country, public investment projects in developing countries will, in most cases, have different characteristics than those in developed countries, where the gap between urban and rural communities is much smaller and where economic and political conditions are more stable (Mawdesley et al., 2005; Dabla-Norris et al., 2012). In many developing countries, the evaluation of investment projects is mainly based on the correlation between the funds invested in a project and the investment return in terms of monetary units or domestic economic growth. This is a macro-economic approach that provides a convenient and easy way to assess the outcomes of a project. However, it can also be inadequate and incomplete (Munda, 2004; Foley, 2006; Alkaraan \& Northcott, 2006). Real-world problems also include human dimensions of, for example, ecological changes, and social perceptions, which are intangible and difficult to identify or measure in terms of money, but which need to be considered regardless.

Costanza et al. (2014) argue that measuring an investment primarily on the basis of economic growth ignores social costs, environmental impact and income inequality, which are part of the well-being of a population. The situation is changing, and over recent decades the world has witnessed the growth of other important criteria, such as meeting community needs and complying with environmental regulations. It is therefore necessary to make sure that investing in projects will respond to these needs and will address them in ways that are both practical and in the best interests of society in the long run. In addition, it is important to select investment projects that will contribute to improving 
standards of living for and services provided to the communities affected by the projects, as well as ensuring that the environment is not harmed. Meeting these needs requires a multidisciplinary approach, because the solution should be geared more towards gaining an understanding of the multiple challenges involved, rather than towards generating the single best economic outcome. For this reason, besides a sound economic evaluation, the techniques for selecting investment projects also need to integrate other relevant aspects and incorporate them into the evaluation and decision-making process for public investment projects.

The current project evaluation and selection process in Thailand may be characterised as a top-down approach, concerned mainly with the country's broader development strategies (Srithongrung, 2009). Empirical studies have indicated that public investment projects in Thailand are typically proposed and selected based on strategic objectives that are not necessarily linked to the needs of local communities. Scientific evidence also shows that the decisions made at the national level do not correspond with the priorities of local communities, but are based instead on the priority of high-level perspectives (Besley \& Coate, 2003), (Shiferaw et al., 2012). The process used is a fundamentally centralised, top-down approach in which decisions are made by a central government, based on the notion that investing large sums of money in large-scale projects will bring more economic progress to the country (Besley \& Coate, 2003). This practice, however, has the potential to further weaken local agencies and communities if they do not have sufficient possibilities to influence proceedings or are withheld funds and initiatives (Lyons, 2009). This may lead to a lack of commitment to strategic projects by local communities. Not involving local communities and failing to incorporate their input into the process is considered an important problem, resulting in a lack of sustainability in public investment projects in developing countries (Shiferaw et al., 2012).

Thailand has been chosen as a representative case for further study because experiences in the country show that, despite the fact that the government invests in a large number of public investment projects to improve the situation in the country every year, local communities often do not experience many benefits from such investments. In addition, a publication by Dabla-Norris et al. (2012) highlights that Thailand scores very low, even among middle and lowincome countries, in terms of the transparency of its selection procedure. 
Based on the addressed problems with regard to project evaluation and decision-making processes in general, as well as the specific case of Thailand, this study arose from a wish to find effective solutions for those shortcomings and thus to improve the public investment project evaluation and selection process.

\section{I.2 OBJECTIVES AND RESEARCH QUESTIONS}

According to the previous section, the focus of this study is on the evaluation and selection of public investment projects in developing countries and specifically in Thailand, which will be used as a case study. The main goal of this study is to develop an integrated decision model that can be used to assist government authorities in selecting the most suitable alternatives and subsequently improve the quality of the evaluation and selection process for public investment projects.

Based on the main goal, the main research question therefore is: How to develop an integrated model that can be used to improve the evaluation and selection process for public investment projects? To find reliable evidence for ways in which to improve the current situation of project evaluation and selection in Thailand, I divided the main research question into the following four sub-questions:

- RQI: What approaches and techniques are available in the field of project evaluation and decision-making in the public sector?

I.I What possible evaluation techniques and concepts are available and what are their respective strengths and weaknesses?

I.2 What relevant decision-making approaches and techniques are available for public investment project decisions and what are their respective strengths and weaknesses?

- RQ2: What is the current state of the public investment project selection process in Thailand?

- RQ3: How to incorporate the relevant concepts and techniques from different disciplines into one integrated model to improve project evaluation and selection processes?

- RQ4: How to validate and test the correctness, efficiency and adaptability of the developed model?

Based on the research sub-questions, the research objectives can be summarised as follows. 
- To identify and integrate concepts and techniques from project evaluation and decision-making disciplines to deal with various issues in public interests.

- To investigate and analyse the current process of public investment project evaluation and selection and the criteria and constraints often used in general situations and in Thailand in particular.

- To develop a project evaluation and selection methodology and an integrated decision model as part of the methodology to improve the current process.

- To test the flexibility, adaptability and robustness of the developed methodology.

\section{I.3 RESEARCH DESIGN AND METHODOLOGY}

Research designs depend very much on the questions researchers are trying to answer. They include research strategies and specific stages, featuring several iterations of designing and investigating the problem-solving process, and span to detailed methods used to implement the design and analysis of the solution (Kabli, 2009), (Wieringa, 2014).

To answer the four research sub-questions (RQ) and achieve the objectives of this study, this section addresses the main four phases of the research methodology used here. The four phases were designed based on the design science research methodology (DSRM) developed by Peffers et al. (2008). The research design and methodology are illustrated in Figure I.I.

As shown in Figure I.I, the research steps are structured in a sequential order, but, in reality, the various steps overlap to some degree. Moreover, communication with stakeholders and users took place throughout the entire study. These parties were informed about the progress of the study and were asked to provide suggestions and information. The main four steps include I) Theoretical review and analysis; 2) In-depth problem investigation in practice; 3) Design and development; and 4) Testing and evaluation.

Theoretical review and analysis: The first phase of this study consisted of identifying general problems in literature about project evaluation and selection. Accordingly, this phase involved reviewing various approaches used in project evaluation and decision-making techniques available in the literature. To achieve these purposes, the relevant approaches and methods, in addition to their application in the infrastructure \& development project selection process, were 
reviewed and analysed in order to identify their advantages and disadvantages in the context of decision-making in Thailand. The results of this phase included an analysis of the selected evaluation and decision-making methods and the possibility of applying these methods with the aim of improving the current process.

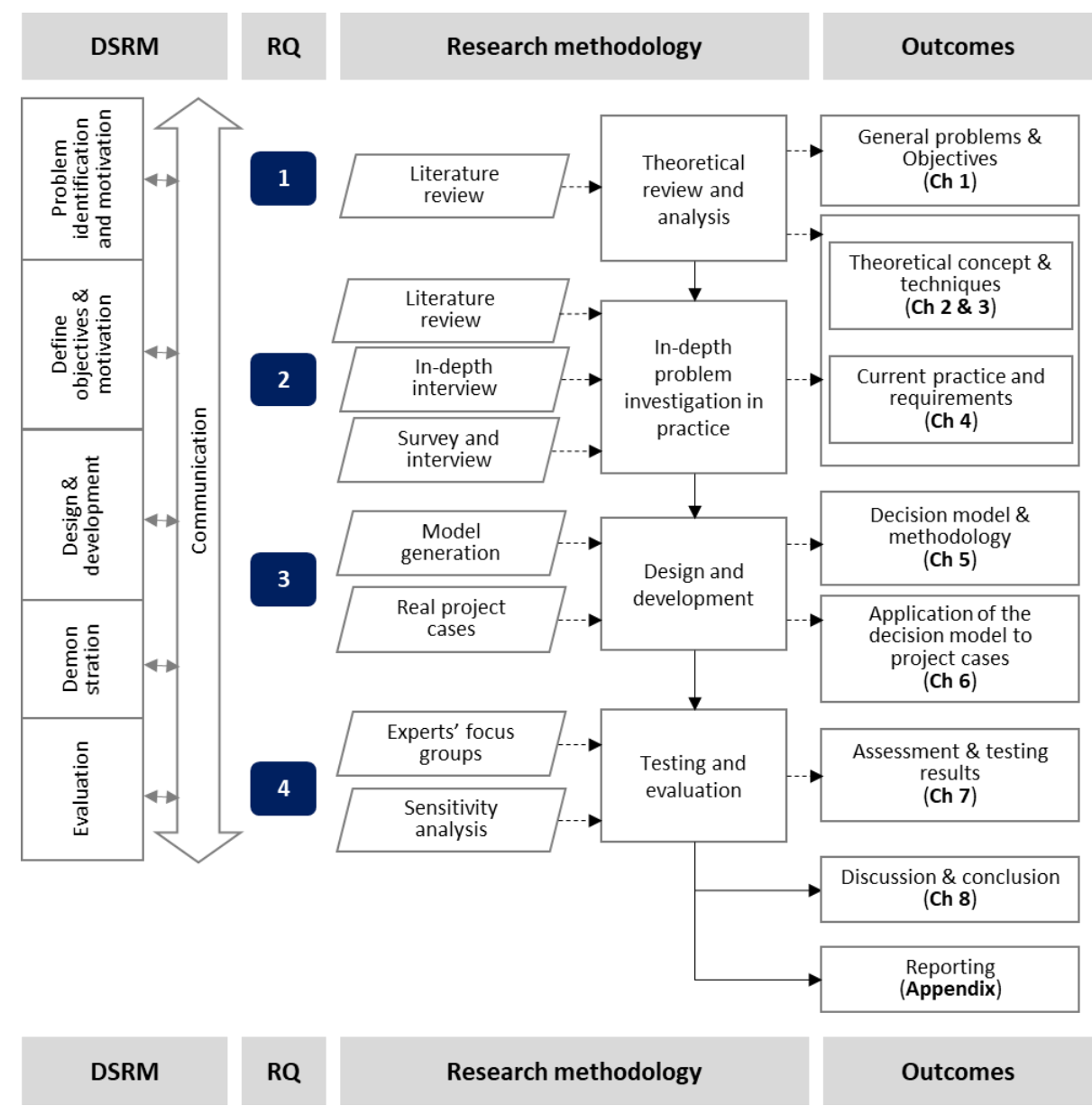

Figure I.I Research design and methodology

In-depth problem investigation: The objective of this phase is to answer the second research question. This phase served to come to an understanding and provide an in-depth description of the status quo concerning the public investment project evaluation and selection process in general, and in Thailand specifically, as well as the common problems in this process. The starting point of this phase 
was to review the general state of and problems with the decision-making process for public investment projects by conducting a literature review. Accordingly, information was collected about the typical course of project selection processes in order to identify the specific characteristics of the Thai system, including its current limitations and shortcomings. The data collection procedure included studying existing documents and regulations, as well as conducting in-depth interviews with public officials from various disciplines and agencies involved in the evaluation, selection and decision-making processes. Moreover, this phase also attempted to find a solution relevant to the characteristics of the current system and user requirements. These requirements were collected through a survey among experts involved in public project evaluation and selection. The in-depth interviews and the survey yielded much insightful information, including required criteria/attributes and key indicators, as well as the interest of local communities and the experiences of public agencies in investment projects. The results of this phase shed a light on gaps in the literature and gaps in practice, highlighting areas for further improvement.

Design and development: The starting point of this phase was based on the results of the previous phase. In this phase, a theory-based conceptual methodology was designed. The full development of the methodology was also carried out in this phase, in order to produce an integrated decision model by modelling not only a single set of attributes, but also including other important aspects and relevant evaluation methods. The entire methodology was designed together with the decision model to be adaptable to any type of investment project and to be flexible enough for any adjustments required in the future.

Testing and evaluation: This is the last phase and final step of the study: the methodology validation and testing process, included in order to ensure that the methodology produces correct and feasible results. This validation was carried out by the researcher to test all constrains, required variables and equations in the model before the full test. In fact, when deciding whether to adopt a decision model, the only real way of telling whether it is good or not is to implement it and wait for the effects to develop. For example, Blanchard \& Fabrycky (20II) state that "a real test constitutes the evaluation of a system deployed in an operational environment and subjected to actual conditions". Even though it would be ideal to wait until the proposed model is completely implemented before evaluating its efficiency and performance, it is not practical, as it may lead to substantial costs, while the model may fail to achieve its 
objectives. Instead, the testing and evaluation of the methodology proposed in this study were carried out in two ways. First, the methodology was assessed in terms of the practicality of the relevant variables used, ease of use, flexibility and adaptability. This was carried out by organising expert panels in various public agencies, which let the researcher obtain valuable feedback on and comments about the applicability of the methodology in their organisations and the current system. Secondly the decision model that makes up part of the methodology was applied to evaluate existing projects, after which the results were tested by means of a sensitivity analysis. Sensitivity analysis is used to provide insight into the robustness of model results when making decisions. The result of the last phase is the analysis of the results produced by the model and a discussion on the further implementation and practical implications of the methodology.

\section{I.4 STRUCTURE OF THE THESIS}

To achieve the research objectives as planned in the research design and methodology in the previous section, this thesis consists of 10 main chapters. Figure I.2 illustrates an overview of the structure of the thesis. Following the introduction chapter, chapter 2 contains relevant literature on project evaluation and various approaches towards measuring project benefits. Chapter 3 covers the literature on and background of decision-making and its various models.

Chapter 4 presents the current practice in public investment project evaluation and selection in developing countries in general and in Thailand specifically, discussing the main shortcomings of the current procedure and areas for improvement. The literature framework in chapters 2 and 3, as well as the problems in practice, lead to the solution to improve the situation in chapter 5.

Chapter 5 introduces an integrated decision model and a corresponding methodology for evaluating and selecting individual public investment projects to improve the current process. The decision model consists of two parts, an evaluation part and a selection part, which are described thoroughly in this chapter. Each part includes several steps and involves the application of various evaluation and selection methods to evaluate competing alternatives and finally assist a decision maker in selecting an appropriate option. Examples are also provided throughout the descriptions of the model. 


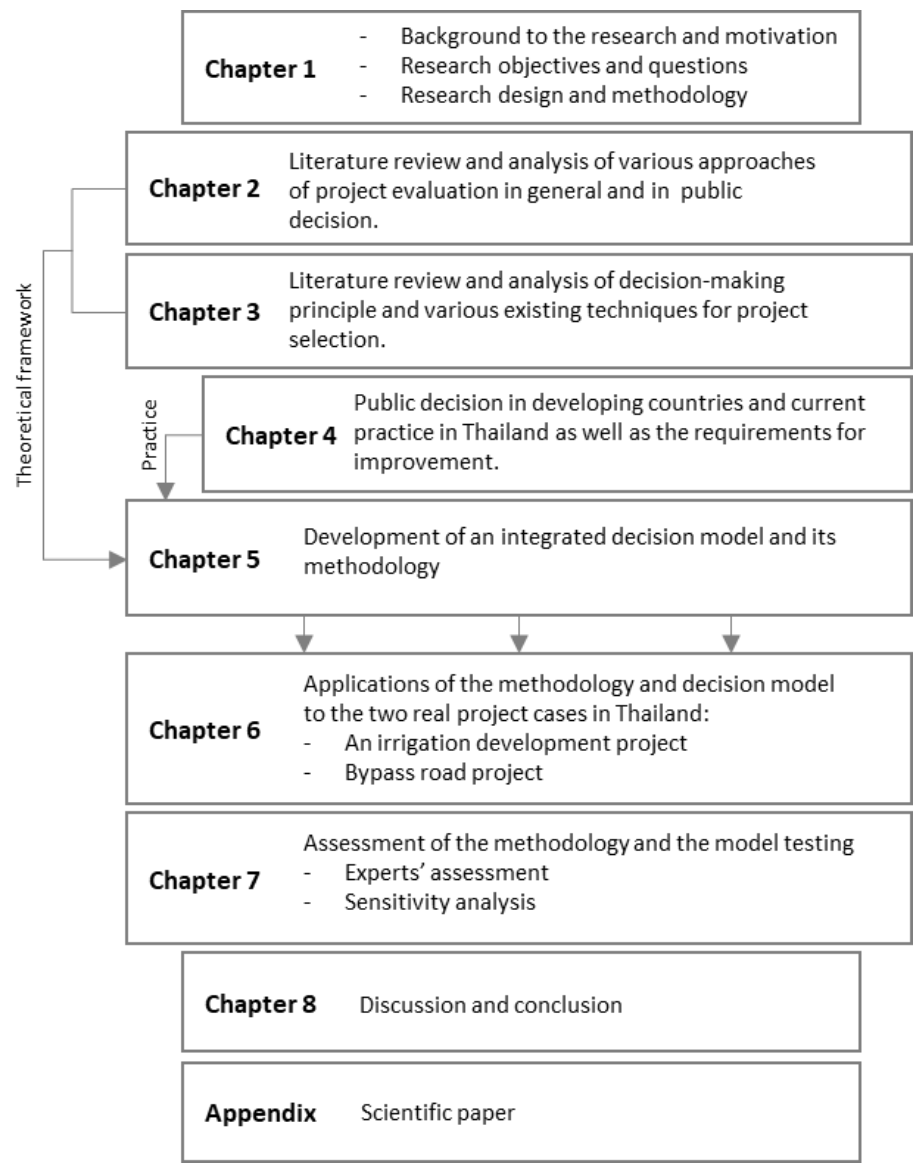

Figure I.2 Structure of the thesis

In chapter 6, the integrated decision model and its methodology are applied to two real public investment project cases: I) An irrigation development project and 2) A bypass road project. The applications of the developed model on the project cases demonstrate several steps of the methodology for evaluating and selecting public investment projects. Additionally, the applications show how the existing data, either quantitative or qualitative, can be translated and transformed into input for the model used to evaluate project benefits. The selection part of the model also presents the importance of decision maker preferences by using a set of important attribute weights assigned by the decision maker. The evaluation and selection results of each case produced by the proposed decision model are discussed at the end of this chapter. 
Chapter 7 describes how the methodology and decision model were assessed and tested. The first assessment was carried out by asking a focus group of experts in Thailand to consider the appropriateness of the decision model and its methodology in practice, based on its ease of use, the relevance of the factors used, and its adaptability and flexibility. The second assessment involved testing the robustness of the results produced by the proposed decision model by means of a sensitivity analysis. The results of two project cases are used for testing, with various sets of attribute weights. The cases show how alternative choices change when the decision maker's weighting preferences change. This provides insight that will help decision makers select an appropriate alternative.

Finally, chapter 8 presents a discussion and conclusions about the decision model and its methodology with research contributions and suggestions for future work and implementation.

In the Appendix, a scientific paper related to this PhD work which has been submitted to a double-blind reviewed scientific journals is included. 
Chapter

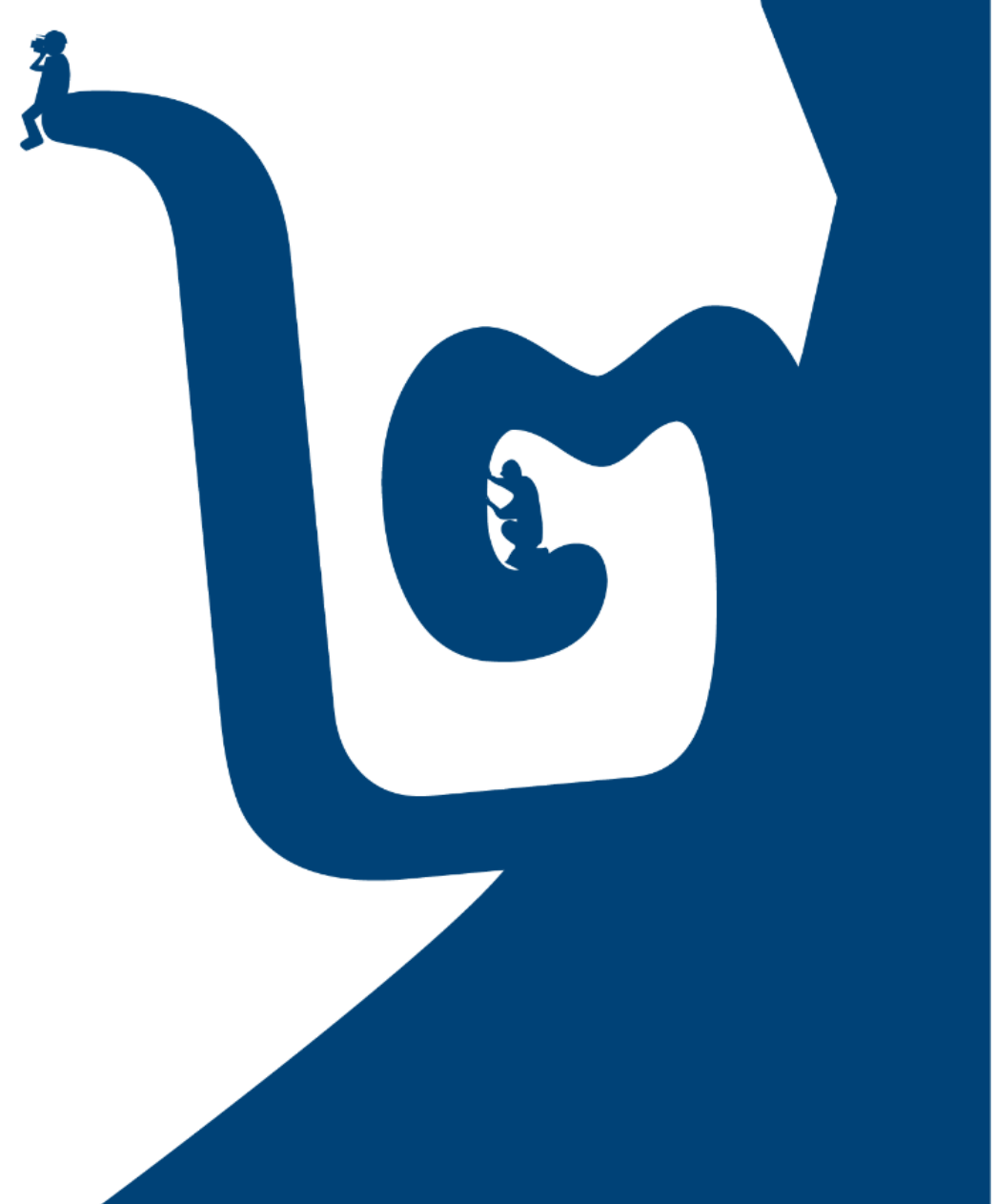




\section{THEORIES AND TECHNIQUES ON PROJECT EVALUATION}

\section{I FUNDAMENTALS OF PROJECT EVALUATION}

In general terms, Lech \& Sussman (20II) defined a project as a set of coordinated activities intended to achieve a specific outcome with a beginning and an end. For the purposes of this study, projects are considered coordinated activities for investing resources in order to satisfy a need or provide a solution to a problem of social and environmental nature.

The definition of a project given by the World Bank (1994) is broader and even includes project evaluation and selection:

A project, ideally, consists of an optimum set of investment-oriented actions, based on a comprehensive and coherent sector planning, by means of which a defined combination of human and material resources is expected to cause a determined amount of economic and social development. The components of a project must be precisely defined as to character, location, and time. Both the resources required - in the form of finance, materials, and manpower - and the generated benefits - such as cost savings, increased production, and institutional development - are estimated in advance. Costs and benefits are calculated in financial and economic terms or defined (if quantification is not possible) with sufficient precision to permit a reasoned judgement to be made as to the optimum set of actions.

In the past project evaluation mainly involved examining the profits and economic returns of public and private investments. Nowadays, the process must be considered from several different viewpoints. A decision on the size of a motorway or a dam cannot and should not be made by a person with limited knowledge and a narrow scope. The set of activities undertaken with an eye on determining the feasibility (i.e. technical, economic, social, etc.) of a project is called project evaluation.

Projects are evaluated for different purposes by people with different backgrounds. If the same proposal were given to two groups of evaluators with different backgrounds such as engineering and social science, the outcome of the evaluation might be completely different. Different aspects of the project would be given different degrees of importance, in accordance with the groups' beliefs and experience. The wide variety of available appraisal techniques with 
different criteria and scores would provide final facts and figures that could lead to the acceptance of the proposal by one group and its rejection by the other.

Most evaluation techniques used are based on Cost-Benefit Analysis (CBA) principles, regardless of what is being evaluated (i.e. social costs and benefits, environmental costs and benefits). CBA is usually considered and applied as a way to describe and quantify the advantages and disadvantages of a policy in terms of a common monetary unit, regardless of the fact that some aspects requiring evaluation are not easily quantifiable in monetary terms. Such practice reflects the general trend followed by planners and decision makers in the past, when money and economy were all that mattered.

In recent years, public and private organisations have started to look at CBA as a practical way of assessing the desirability of projects, not just financially, but also in terms of their wider impact in the future as well as the near future. Consequently, the scope of project evaluation has also changed and examples of broader and more careful estimation of non-economic factors are becoming more common. Unfortunately, many organisations are still reluctant to look at social and environmental issues as carefully as they look at financial matters.

Cost-Effectiveness Analysis (CEA) is suggested as a preferred alternative to CBA in cases where benefits and costs vary, but cannot be measured in monetary terms (Shaner, 1979). The fundamental difference between these approaches is that CBA estimates the economic costs and benefits resulting from a project, while CEA evaluates and compares alternative projects that do not produce traded goods but qualitative benefits (Sanders et al., 2016; Dawson, 2008). The important element in CEA is the use of procedures that minimise the monetary cost of a given level of activity, whilst the benefits are measured in physical units or simply stated as a policy objective, and the costs are expressed in monetary units. At the very least then, alternative means of achieving the same objective can be ranked in terms of the ratio of cost to effectiveness (C/E).

Both CBA and CEA have remained popular over the years in government decision-making. Most texts that discuss this aspect deal with them from the perspective of a government analysing public-benefit or development projects. However, projects are not exclusively a matter of economic development, and costs and benefits do not refer to monetary terms only. The concept of project 
evaluation has evolved and come to imply the analysis and appraisal of any sort of project, regardless of the type of organisation or the benefits involved.

\subsection{ECONOMIC AND FINANCIAL EVALUATION}

An investment decision is a decision to commit the organisation's financial and other resources to a particular course of action. The economic aspects of projects have always been considered a fundamental part of the process of evaluation and decision-making, probably due to the close relationship between economics and the massive allocation of monetary resources to projects.

A probable justification for the overwhelming importance given to economic matters while evaluating a project can be found in the words of Remer \& Nieto (1995), when they say that:

Profitable capital investment leads to the growth and prosperity of an economy. If profitability is low investment will shrink.

While the authors do have a point, several objections may also be raised against it. In the first place, if the growth and prosperity of an economy depend on profitable capital investment, social benefit projects would be excluded from all national accounts simply because they are not profitable. Additionally, if projects evaluation is seen from a private viewpoint, then the economy of a country or a region is not the most important issue when evaluating an investment option. A private company is generally more concerned with the future of the organisation than the prosperity of the society.

Scarcity of resources is oft-used argument in defence of the importance of economic aspects of project evaluation. Both private companies and government organisations have a limited amount of economic resources to invest and, therefore, a careful study of the allocation of financial resources and their returns is necessary (Meredith \& Mantel, 20I0).

An important element of economic evaluation is "the time value of money" aspect. Essentially, what is meant by the term is that a given sum of money has a different value depending upon the time at which it changes hands. The idea is not directly concerned with inflation or deflation (in order to achieve this, the assumption that price levels are stable through time must be made), but is 
connected to the fact that money can be invested so as to earn interest (Lumby, 1991).

According to Pike \& Neale (2006), there are at least four reasons why the value of money varies over time:

- Risk. $€ 100$ now is certain, whereas $€ 100$ receivable next year is less certain. This principle affects many aspects of financial management.

- Inflation. Under inflationary conditions, the value of money, expressed in terms of its purchasing power with regard to goods and services, declines.

- Personal Consumption Preference. Most people have a strong preference for immediate rather than delayed consumption.

- Investment opportunities. Even if the reasons above are ignored, the fact that remains is that money has a price. Given the choice of $€ 100$ now or the same amount in one year's time, it is always preferable to take the $€ I 00$ now because it could be invested over the next year at a specific interest rate.

The other important element which plays a very important role in the process of economic evaluation is interest rate. Interest rates are used to determine the value of money to a particular point in the future and discount rates are used for the opposite purpose. Virtually all modern texts on project evaluation such as (Park, et al., 2005; Topal, 2008; Biezma \& San Cristobal, 2006) seem to conclude that the preferred methods of evaluation are those that incorporate annual cash flow projections and that recognise the time value of money. Unfortunately, the literature on discounted cash flow (DCF) does not deal satisfactorily with the selection of discount rates for development projects, see for example (Miyao, 2000; French \& Gabrielli, 2005). In particular, texts fail to provide adequate methods for the estimation of discount rates for publicbenefit projects.

\subsection{ECONOMIC EVALUATION METHODS}

In order to describe what evaluation methods are about, it is important to clarify some of the concepts used in economic evaluation, such as costs and benefits.

There are different types of costs and benefits and their uses are also varied. In project evaluation, the most common concepts are gross benefits, net benefits, 
costs and cost of opportunity. These concepts fit into a simple equation that illustrates their differences. By subtracting costs from gross benefits, net benefits are obtained. Some authors in the field of social appraisal define net benefits as the remainder after subtracting [social] cost opportunities (i.e. the difference in worth of allocating capital to one option and not to another) from gross benefits (Shaner, 1979).

In the following section, a description of some common evaluation methods is presented. Some of these methods take into account the value of money described earlier and some others do not. Mishan \& Quah (2007) call the latter crude investment criteria for this reason. In this chapter this term is also adopted to classify the methods.

\subsection{Crude investment criteria}

Cut-off period. This criterion is mainly used in industries that develop new products. A suitable period is chosen over which any money invested must be fully recouped. This period is usually ten years or less in most first world countries. The reason for choosing this period is because it will not take more than ten years before the product has been equalled or improved by competing firms in the international market. Another reason for this period is that trying to keep the product in the market after that time would require incurring greater marketing and administrative costs. The method is used for innovation in products or methods that cannot be protected by patents and can be copied by other firms within two or three years. One of its strongest disadvantages is that outlays must be fully recouped within the first years in order to get a higher profitability or feasibility, despite some other options offering better revenue in the long term.

Pay-off period: Instead of an arbitrary cut-off period, the options are ranked according to the years necessary to recoup the initial outlay. An auxiliary tool used along with this criterion is the pay-off period rate of return, which yields a number by dividing 100 by the number of years in the pay-off period, based on which a decision can be made. This criterion is used under circumstances of imitation by competitors, rapid anticipated obsolescence or political uncertainty to guarantee safety.

Payback method and speed of payback: A slightly different view of these two methods is offered by Lumby (199I), who calls it the payback method. In this case, the method is used to determine how quickly the incremental benefits 
that accrue to a company from an investment project 'pay back' the initial capital invested, with the benefits normally defined in terms of after-tax cash flows. This method can be used as a guide to investment decision-making in two ways. When faced with a straight accept-or-reject decision, it can provide a rule where projects are only accepted if they pay back the initial outlay within a certain predetermined period (cut-off period). In addition, the payback method can provide a rule when comparison is required to the relative desirability of several mutually exclusive projects. In such cases, projects can be ranked in terms of 'speed of payback', with the project with the fastest payback rate being the most favourable option.

The example in Table 2.I illustrates the payback method used for both decision-making situations. For project $A$, assuming that the cut-off period for project acceptance is five years (maximum), it can be seen that the project should be accepted because it pays back the initial outlay of $€ \mathrm{I}, 500,000$ within this period.

Table 2.I Example of the payback period of a project (adapted from Bragg, 2018)

Project A

\begin{tabular}{|l|r|r|}
\hline Year & Cash flow $(€)$ & Net invested cash (€) \\
\hline 0 & & $-I, 500,000$ \\
\hline 1 & $+I 50,000$ & $-I, 350,000$ \\
\hline 2 & $+I 50,000$ & $-I, 200,000$ \\
\hline 3 & $+200,000$ & $-I, 000,000$ \\
\hline 4 & $+600,000$ & $-400,000$ \\
\hline $5>$ Payback period & $+400,000$ & 0 \\
\hline
\end{tabular}

Taking the same cash flow as project $A$ in Table 2.I, a comparison between 2 projects is shown in Table 2.2 which ranks project $B$ as having the fastest 'speed of payback', therefore making it the preferred investment.

Table 2.2 Project comparison with the payback method

\begin{tabular}{|l|l|l|l|}
\hline Year & Cash flow $(€)$ & Year & Cash flow $(€)$ \\
\hline 0 & $-1,500,000$ & 0 & $-1,700,000$ \\
\hline 1 & $+150,000$ & 1 & $+200,000$ \\
\hline 2 & $+150,000$ & 2 & $+300,000$ \\
\hline 3 & $+200,000$ & 3 & $+400,000$ \\
\hline 4 & $+600,000$ & 4 & $+800,000$ \\
\hline 5 & $+400,000$ & & \\
\hline & & 5 & $+400,000$ \\
\hline 6 & $+300,000$ & 6 & $+400,000$ \\
\hline & Project A & & Project B \\
\hline
\end{tabular}


Average rate of return: Obtain the algebraic sum of benefits plus costs for the first year and repeat the operation until the last year. Divide the sum by the number of years considered and divide the result by the original cost. If necessary, multiply by 100 to see the results in percentage form. This method favours projects that offer profits exceeding the original costs in the first years, but is suitable for projects with longer terms, which may offer better benefits in the long run. The method can be represented by the following equation:

$$
A R R=\frac{100}{n\left(I C^{-1}\right)} \sum_{t=1}^{n}(C+B)
$$

where:

$\begin{array}{ll}\text { ARR } & \text { is the Average rate of return (\%) } \\ n & \text { is the number of years } \\ C & \text { is the cost } \\ B & \text { is the benefits } \\ I C & \text { is the initial cost }\end{array}$

Net average rate of return: The procedure is similar to the gross average method, but includes subtracting the original outlay (cost) before dividing the total sum by the number of project years in order to obtain the project's net benefits. Disadvantages of this method can be that for short periods, a small net benefit in one of the years will bring down the final rate, and, perhaps more importantly, that the method is completely indifferent to the distribution of money over time, e.g. (- 100, I, I, I, 297) or (-100, 297, I, I, I).

While the non-discounting or crude investment methods are quite easy to use, especially as tools for assessing the viability of developed schemes, they suffer from many drawbacks, because the timing of the cash flows, the comparative magnitude of the investment, and differences in project lifespan are all ignored. Therefore, the methods that are regularly used in project appraisal and investment decisions are not always only non-discounting methods. More complicated Discounted Cash Flow techniques (DCF) are also found to be useful for investment decision-making, although the techniques used should preferably reflect the time value of money (Abdullah \& Nordin, 2008). 


\subsubsection{Discounted Cash Flow techniques (DCF)}

In order to consider the real value of money over time, the value of an investment is determined as the present value of a future cash flow, which is equal to the discounted value of all estimated future liabilities and benefits (French \& Gabrielli, 2005). In calculations that represent the future value of money, an interest rate $i$ is used, whereas in the opposite process, a discount rate is used instead. In the latter process, the value of money in the future is discounted to its equivalent value at the present and the cash flows are brought to $\mathrm{t}=0$ (discounted flows).

In general, the terminal or future value of an initial of €invested today at a compound rate of interest $i$ for $n$ years will be:

$$
F=I C(1+i)^{n}
$$

The present value works in the opposite direction. Taking the previous formula and dividing both sides by a compound rate of interest $i$ for $n$ years, the following formula is derived:

$$
P=\frac{F}{(1+i)^{n}}=F(1+i)^{-n}
$$

Usually, the discount rate for financial analysis is the interest rate at which bank loans are available or, if the company's own funds are used, the rate that banks would pay on the deposit of such funds, that is to say, their opportunity cost (Velnampy, 2005). However, an investor will always ask for benefits over the capital invested. In order to make this possible, one should consider that the minimum acceptable rate must, at least, equal inflation, thus keeping the value of money equal. As the investor is trading the certainty of his capital for the promise of better benefits in the future, a surplus rate has to be added for the risk of investing his money.

This does not apply in the case of projects for public benefit, where the aim of the investment is not short-term profit but long-term social welfare in the form of education, healthcare and basic services. The discount rate used in these projects can be lower than those in the business sector (Lopez, 2008). Another reason for this consideration is the fact that there are several international 
agencies that finance development projects and offer lower rates than the banks.

Discounting methods are widely used in corporations and trend shifts from one to another from time to time, as can be seen in the papers by Remer \& Nieto (1995) and Abdullah \& Nordin (2008). If a decision-maker understands clearly the meaning of the different techniques and the profit measures derived from them, there is no reason why he could not use all of them for the restrictive purposes for which they are appropriate.

Even though it is not an exhaustive catalogue, the most commonly used techniques and measures are described in the following paragraphs.

Net Present Value (NPV). This investment assessment method is a way of comparing the value of money now with the value of money in the future. A euro today is worth more than a euro in the future because inflation will erode its purchasing power, while money available today can be invested and grow. In order to do this, a discount rate is required to compare the benefits and costs distributed over the lifespan of the investment (Harberger, Jenkins \& Kuo, 1997; Mulder, 2006). In general terms, the NPV can be expressed as follows:

$$
\sum_{t=0}^{n} \frac{C_{t}}{(1+i)^{t}}=N P V
$$

Here, $C_{t}$ is the project's cash flow (either positive or negative) in time $t$ and $i$ is the discount rate.

The general rule is to take the project with the highest positive NPV for the following reasons:

- A negative NPV project is unacceptable because it indicates that the project makes a loss relative to a capital market investment (i.e. an opportunity loss).

- A negative NPV project produces a return less than that available for a similar level of risk on the capital market.

- A negative NPV project would not generate sufficient cash flow to repay the financial costs of undertaking it.

Benefit-Cost Ratio (B/C ratio). The Benefit-Cost Ratio may be defined as the ratio of the discounted benefits set against the discounted costs at a 
certain, identical point in time (i.e. the discounted benefits per unit of discounted costs). Sometimes it is referred to as the savings-to-investment ratio when the benefits are derived from the reduction of undesirable effects (Au \& Au, 1992). This measure can be used as an auxiliary to the NPV to differentiate between projects with large discounted benefits and high costs, as well as projects with a lesser profit but a better return for every unit invested.

The Internal Rate of Return (IRR). The IRR of a project can be defined as the discount rate which, when applied to the project's cash flows, produces an NPV of zero (Jenkins, Kuo \& Harberger, 20II). In general terms, the IRR is the value for $i$ that satisfies the expression:

$$
\sum_{t=0}^{n} \frac{A}{(1+i)^{t}}=0
$$

Analysis of the equation reveals some interesting features of the IRR method. From a mathematical point of view, the first idea that arises is that there is not one solution to the equation but several. The solution is unique when the cash flows have only one change in the sign, which, in real terms, either implies an initial outlay or a series of outlays followed by a series of incomes afterwards. In some cases, IRR may still have a single value even if there are two or more sign reversals in the cash flows. In general, the IRR equation relates to $n$ years and, therefore, has $n$ roots. However, with conventional cash flows (i.e. only one sign change) only one of the solutions is a real number and the rest are imaginary numbers. Some authors, such as Lumby (199I), consider the IRR to be nothing more than an arithmetic result of the NPV method rather than a method in and of itself. For cash flows with two or more sign reversals, the multiple values (i.e. solutions to the polynomial) do not have economic significance.

The most common ways of estimating the IRR are by means of trial and error or linear interpolation. The decision rule is that only projects with an IRR equal to or greater than some pre-specified cut-off rate should be accepted. The cut-off rate is usually the market rate of interest. (i.e. the discount rate that would have been used in the NPV analysis). 
Discounted Payback. Having examined the application of the simple payback (PB) method as a crude investment criterion, it is interesting to look at the discounted cash flow version. According to authors such as Levy \& Sarnat (1995) and Yard (2000), the simple PB has a major limitation because it does not take the value of money into account. What the discounted payback technique does is to see quickly a project pays back its costs in present value, rather than in undiscounted terms. Unfortunately, this technique, as well as its undiscounted counterpart, only works for typical projects that incur major costs in the beginning and recover afterwards. The reason for this is that payback methods only show the capital recovery period without looking at the characteristics of the cash flows in the remaining periods.

\subsection{SOCIAL EVALUATION OF PROJECTS}

When evaluating projects, decision-makers often tend to think about them as entities that exist only in the economic and financial world. In doing so, they ignore the fact that most investment projects, physical or otherwise, are ultimately undertaken to satisfy human needs and develop and improve services (Mishan, 1982). In many cases, investment and development projects create important links and relationships between society and the natural environment in its immediate vicinity and beyond (Mulder, 2006). An example of a public road construction project is a clear case which illustrates the inadequacy of the exclusive use of financial measures to evaluate projects, as well as the need to account for other type of benefits. The application of purely financial criteria for such a project would produce absurd results.

The road example provides a good opportunity to highlight some other social benefits that should be more important than revenue in road construction projects and others similar projects. Roads allow for communication and provide mobility to people; they promote commerce between distant regions; facilitate the provision of aid in case of emergency and have many other effects which cannot be expressed in terms of revenue.

When evaluating a project from a social point of view, economics do play an important role, but not in the same sense as in a financial appraisal. Social evaluation concentrates on aspects such as community development and welfare, satisfaction of basic needs and the economic effects of projects on society, as well (Todaro \& Smith, 20I5). Decision-makers act on behalf of the government and are supposed to defend the interests of the country or region. 
The use of economic criteria and measures in project evaluation implies that all benefits and costs can be expressed in monetary units. However, economists recognise the existence of non-monetary attributes or effects and have made some efforts to account for them in the form of shadow pricing (Harrison, 20I0).

According to Harrison (2010), a shadow price (or accounting price) is a price that is imputed as opposed to being taken directly from market transactions, either because no market price exists, or because the market price is considered inappropriate. Through shadow pricing, the non-monetary benefits to society (or efficiency effects) of a government project are calculated by assessing all project inputs and outputs for society and converting them into costs and benefits that reflect the social value of project inputs and outputs.

Shadow prices can be obtained by calculating or estimating the prices to be used in determining the true value of benefits and the real magnitude of cost (Todaro \& Smith, 2015). In certain cases, indirect valuation methods of a more or less satisfactory nature have been adopted for these intangible items. Some examples of these procedures include:

I) Highway improvement will reduce travel costs for individuals, and, as such, time saved is a way to measure the benefit obtained. The personal value of time, in turn, may be derived from observing the differential prices paid under systems of transportation involving differences in travel time.

2) A school programme aimed at reducing absenteeism will be reflected in reduced delinquency rates and thus save law enforcement costs. Other gains may be measured in terms of increased earnings due to improved education.

3) A medical program may result in reducing the death rate from a particular disease. The resulting benefit (or at least part thereof) may be measured by looking at the corresponding prevented loss of earnings.

4) The value of a noise abatement programme for aircraft may be measured by the observed increase in property values in areas adjacent to airports.

While these criteria seem to be a quite simple way of assigning monetary values (or shadow prices) to intangibles, it overlooks their real importance (Munda, 2004; Alkaraan \& Northcott, 2006). The examples described here do not 
provide complete satisfaction about the procedures to estimate equivalent measures. For example, in the case of higher earnings associated with improved training, there are several points to discuss. First of all, if planners follow this criterion, they will find themselves in the position where projects for higher education (i.e. universities) will always be ranked better than basic education projects (i.e. reducing illiteracy). The reason for this situation is that earnings associated with people with degrees are much higher than earnings of people who can only read. This raises another issue about the distribution of income. Wages are not the same in every region of a country, and therefore if the same agency was evaluating projects in two different zones, zones characterised by higher wages would be preferred to poorer zones (Todaro \& Smith, 2015). The overall picture shows that, by following this method, people could incorrectly conclude that higher education projects in zones with higher wages are better than literacy projects in poor regions.

Hence, this method must be applied with great care in order to avoid bias and misinterpretation of reality for the sake of obtaining a monetary equivalent.

Social-benefit projects require a clear definition of objectives and needs in order to allocate the government's limited resources efficiently and provide the correct social group with the benefits they require. These goals must be prioritised and the main beneficiary groups must be carefully identified.

\subsection{Cost-benefit analysis and the social discount rate for projects}

Cost and benefit estimates should involve a comprehensive and systematic evaluation of all the impacts of a project on all people in society (Boardman, et al., 2017): not just the immediate or direct effects, not just financial effects, and not just the consequences for one group. All effects of a policy proposal that are considered desirable by those affected are benefits, all undesirable effects are costs. Cost-benefit analysis (CBA) uses willingness to pay to measure benefits and opportunity cost to measure costs. The relevant costs and benefits are not limited to financial benefits but also include social benefits such as cultural, environmental and other non-market losses and gains (Harrison, 20I0). Sometimes, non-monetary benefits are difficult to identify and evaluate, but they should not be ignored.

The calculation of the discount rate is normally different and depends on the type of organisation evaluating the project or on the type of final benefits 
generated (Dobes, et al., 2016). One of the problems of choosing a discount rate for public-sector investments is that the alternative use of capital cannot be measured in standard terms. To illustrate this idea, consider a government trying to invest $€ I, 000,000$ in a project. The alternative use of that capital (and, therefore, its cost of opportunity) in theoretical terms should be the same risk-free investment as the one offered by banking institutions. The problem with this assumption is the fact that governments do not put their capital into banks and, therefore, that interest rate cannot be applied.

According to Harrison (2010), the efficiency-based approach to the social discount rate boils down to determining the opportunity cost of capital used in the project. This 'opportunity cost' is the appropriate discount rate to determine a project's capital value. Some label the efficiency-based social discount rate derived from opportunity cost as the descriptive approach, and instead argue for a prescriptive approach, especially when considering policies that affect future generations.

The prescriptive or normative approach directly specifies a discount rate that society 'should' use to discount future consumption flows, based on ethical principles (sometimes literally appealing to the ideas of philosophers). It mixes efficiency and equity considerations and is often advocated when projects affect future generations.

Specifying the rate at which society is willing to trade present for future consumption is bound to be controversial. 'Society' is not a decision-maker (not even the government controls the whole of society). Inevitably, analysts impose a specific discount rate (or the parameters that determine it), but economists have no particular expertise with regard to how one should account for the future .

Harrison (2010) also indicates that the issue is a complicated one and that theory is far ahead of our empirical knowledge on this subject. The reason is that the social discount rate depends on parameters that little is known about or that are difficult to estimate. While efficiency is an important goal of public policy and should be given due focus, it is only one consideration. It is therefore not surprising that there is little agreement about the most appropriate approach. What is ethical depends on value judgments and there is no way to reconcile the different value judgments that people may possess. Equity issues involve trading off the welfare of one group against another's (for example, the 
present generation's against future generations'), but there is no general consensus about the weight that should be attached to the welfare of different groups. The prescriptive approach makes the discount rate a matter of opinion and provides no basis for determining which opinion is correct.

There are several approaches to the estimation of the social discount rate. Not all of them are completely satisfactory, despite economists' efforts over the years. However, in a mixed economy with market imperfections, no single discount rate can be taken as a measure of both time preference and the productivity of capital. Two types of discount rates have been considered:

- the "social time preference" (STP)

- the "social opportunity cost" (SOC)

The social time preference rate is the rate of fall in the social value of consumption by the public, as opposed to public sector income. A social time preference function assigns current values to future consumptions; it is a normative function reflecting society's evaluation of the desirability of consumption at different points in time.

The social opportunity cost is a measure of the value to society of the next-best alternative use to which funds employed in the public sector might otherwise have been put.

Boardman et al. (2017) suggest that the STP and SOC can also be combined into a shadow price of capital as a ratio of SOC to STP and multiplying relevant costs and benefits to convert them to consumption equivalents that can then be discounted using the STP.

\subsubsection{Cost-effectiveness analysis}

Usually, CBA has been associated with industrial or privately funded projects for which it is reasonable and simple to put benefits and costs into monetary terms. If the government is the sponsor, project indicators are compared with alternative uses of available capital to determine whether the project is a good use of public funds. However, accurate estimation of benefits is the difficult part (Lech \& Sussman, 20II). Use of public funds imposes a need to analyse the effect on targeted beneficiaries, which is a function of services, income level and social status where most are achieved by means of intangible benefits.

For these reasons, Cost-Effectiveness Analysis (CEA) is often seen as a more appropriate economic technique than $\mathrm{CBA}$, as it quantifies benefit through one 
of the standard outcome measures that capture morality, quality of life or effects on overall well-being (Dawson, 2008). For CEA, the outputs or benefits can be stated in terms of the actual substantive outcomes rather than in monetary values.

One of the problems faced by decision-makers is that these outputs sometimes do not have "substantive outcomes" in measurable units, such reduced illiteracy or peacefulness, which means that subjective measurements have to be made. CEA attempts to identify either the least cost method of achieving an objective or the maximum output that can be attained at a given cost. Both the objective and the output are usually mono-dimensional (i.e. for a health service project, the decision variable could be the cost per case treated).

Unlike CBA, this technique fails to provide information about whether the objectives established for the project are met. A project can be cost-effective in the sense that it meets its goals at the least cost, but the value of the benefits achieved is not considered. It is for this reason that a parallel evaluation must be performed to consider these factors.

\subsubsection{Subjective social measures}

In the fields of social services, public policy-making often focuses on protecting and improving the quality of life (QoL) and well-being of populations, regardless of the financial benefits involved. The decision-makers and researchers working on social intervention projects in the past and present have sought a solution to measure the QoL and population well-being in an affected society. In a large section of social research on this matter, the general context of these social issues is a shared similar interest in what it means for different people to live well or badly in their environment (Camfield, 20I2). The links between and use of objective and subjective measurements have been explored by a number of studies that are used as social indicators. The concept of social indicators was first developed by Bauer (1966) who intended them to be instruments for assessing social change and therefore for aiding in policy decisions to evaluate specific projects and programmes (a set of projects) and their impact.

According to the review of social indicators by Casas (201 I), assessing QoL and social impact involves measuring material (such as money and property) and nonmaterial (such as values and feelings) characteristics of life in a large population. This means more and different types of data are necessary for measuring complex social realities. 
In developing or poorer countries, social indicators are related to income and poverty measures, especially in rural areas, and they seem more critical than in rich countries due in part to their relationship to basic needs and life satisfaction (Veenhoven, 199I), (Oishi, et al., 1999), (Alkire \& Santos, 20I I). While the rural areas have needs related to such as money and assets, and lack of work; the primary concern in urban areas is the living environment, with issues such as overcrowded, unsanitary housing, dangerous streets and violence, for instance (Brock, 1999). Based on the literature, there seems to be a high degree of social interest in satisfaction with income and life satisfaction for QoL and with wellbeing in developing countries.

In fact, describing real-life social situations is imprecise and these measurements could only provide approximations at best (Casas, 20II). Understanding and identifying the situation in a particular country requires a transparent, traceable procedure for tackling the problem. Many researchers were no longer interested only in the general well-being of populations, but also wanted to understand micro-social well-being in greater detail and with more precision. A study by The World Health Organisation (WHO) (The WHOQOL Group, 1995) developed a process to assess the QoL in several domains, including the physical domain, social relationships and religion. The exploration of QoL was constructed across cultures to investigate those QoL domains in different cultural settings and among different groups within the same cultural setting. Massam (1999) has suggested using a set of observation units to capture specific problems, such as regions, cities, census tracts or individuals. A set of indicators or criteria which characterise components of QoL and scores for all factors should be combined into a single score for each individual. The information required to tackle the problem must be also included, such as the importance of the factors involved, and the data types used to describe the scores.

The review of subjective social evaluation described above clearly explains how the evaluation aimed at tracking a project's impact on society is moving forward to measuring QoL and how people's perception of their situation may be influenced by an investment project or programme. There is no single solution that can be applied in all cultures or countries, but most studies have, regardless, made an attempt to determine which units or individuals benefit or suffer under policy decisions. 


\subsection{DISTRIBUTIONAL ISSUES}

A concern shared by all governments is dealing with the problem of sub-optimal distribution of income which affects equality and the overall well-being of a country. At the same time, redistribution through fiscal and macro-economic measures is not enough to optimise said distribution. A cost-effective alternative is using social-benefit projects in addition to general economic instruments to help achieve an optimal distribution of income. Relying on the concept of social welfare and optimal distribution, they all revolve around the priority given to various individuals and sub-groups as well as their differing income levels (Cowell \& Gardiner, 2000; Adler, 2016). The analysis should consider using distributional weights that can connect benefits to relevant social and ethical views and make it explicit (Fleurbaey, et al., 2013).

Consider the example of an industrial project which is going to generate 1,000 jobs, in which there are two alternative locations for the plant. Alternative $A$ locates the plant in an area where the wages for unskilled labour are relatively high and the costs of materials, capital and transportation are quite low. Alternative $B$ locates the plant in an area where labour wages are low and costs are average. In the absence of distributional considerations, alternative $A$ is the best option, since it has a higher cost-benefit ratio. However, if distributional weights are allowed for, alternative B would rank higher because it benefits lowwage earners.

According to Harrison (2010), the use of distributional weights for project evaluation depends very much on the particular circumstances of the case in question. Weights are bound to be different depending on the utility function of the organisation in charge of the project, regardless of whether it is private or public. It is interesting to mention that these considerations also apply in the case of public purchases in general. Whereas the general rule should be to invest where the cost is least, exceptions may be raised based on the use of distributional considerations.

People have realized that there are difficulties in the process of assigning distributional weights to the various attributes (costs and benefits) of projects. Moreover, the benefit mix can vary depending on how the project is designed, and the design may affect the way in which similar benefits are divided among various sectors of the economy or income groups.

Once net project benefits have been identified and allocated to beneficiary 
groups properly, the next step is to "weight" each group according to some generally agreed scheme. Some forms of income (i.e. that received by very poor people) might have a higher weight than the price of goods.

In 1974, Little \& Mirrlees developed a utility function. In this method, they consider that there will be some level of personal income at which an extra unit of income is estimated to yield the same social utility as an extra unit available for the government. More uses of distributional weights in a decision to mimic a concept of social welfare economics have been reviewed by Adler (2016). There are, however, many difficulties in establishing the values of all parameters used to provide an explicit set of distributional weights, since it is not always easy to identify beneficiaries and their social preferences (Scarborough \& Bennett, 2008).

Most texts describe several difficulties in the use of weights, but many of them are subjective and tend to put them aside for the simple reason that they imply more work for the people in charge of decisions. However, it is recognised by both authors and evaluators that there is no solid evidence that the use of weights is inadequate. It is hard to see how a method for project evaluation that treats all the beneficiaries equally can offer better results, in sociopolitical terms, than one that gives greater weights to the preferences and needs of the poor.

After analysing all the arguments presented against the use of distributional weights, the real difficulties can be summarised in two major ideas:

- The identification of the groups of direct beneficiaries and the income streams that accrue to these groups.

- Weights cannot be explicitly determined despite all the attempts that have been made previously to derive weights through past government decisions or other means. As a result, they are not globally accepted or used in a consistent way to evaluate projects.

A survey carried out among the project-evaluating staff at the World Bank (Narayan, 1996) showed that they are opposed to the use of weights for the following reasons:

- Subjectivity. The use of distributional weights requires judgment about the value of marginal increases in income to different members of society which staff were extremely reluctant to make, even though they recognised that the use of equal weights for everybody was itself 
a value judgement.

- Practicality. Many staff members held the view that the task of identifying who actually benefited from a project was overwhelming.

- Efficiency. While government should clearly be concerned about the distribution of income, project selection was not considered the most efficient instrument for pursuing this goal.

Without questioning the validity of the opinions expressed by the World Bank's staff, one cannot just ignore the fact that distributional weights try to balance somehow the inequality in the distribution of benefits arising from social projects.

\subsection{ENVIRONMENTAL ASSESSMENT}

Over decades, many studies and practices in many countries made significant progress towards sustainable development, and this has given more attention to environmental matters and the need to reduce the burden on the environment. There are many environmental issues to be assessed for a project, which vary depending on the specific impact and type of the project in question. Examples of relevant environmental issues include emissions, energy consumption, environmental fragility of the habitat, noise pollution, community disruption, tourism disturbance (Cadena \& Magro, 2015; Garmendia et al., 2010).

Most environmental studies have attempted to include a broad range of natural resources and social issues in evaluation methods in order to reflect the significance of the concept of project sustainability (Ding, 2008). Two widely accepted tools for assessing the environmental implication of a decision are the environmental impact assessment (EIA) and the strategic environmental assessment (SEA). The outcome of the EIA/SEA is a feasibility report which can materially affect investment decisions (Ramanathan, 200I; Ogola, 2007; O'Fairceallaigh, 2010). Due to the increasing concern for the people affected by projects and statutory environmental regulatory authorities, the EIA and most environmental assessments usually also include, besides environmental, cultural, social and economic considerations in order to identify the consequences for bio-geophysical, human health and welfare, and socio-economic impacts of a project's implementation (Foxon et al., 2002; Dey, 2006; Ramanathan, 200I; Ding, 2008; Garmendia et al., 2010). 
In many cases, however, the common environmental assessment is not entirely satisfactory for decision makers (Ramanathan, 200I). According to Lee Jr. (2000), environmental assessments that follow from statutory schemes are not a completed evaluation procedure. They simply do not shed much light on whether a project is good. This might be due to its complex multi-dimensional process and overwhelming descriptive information provided by the experts in the assessment results. Several studies have addressed the need to improve environmental assessment by including multi-criteria/attribute decision analysis (MCDA/MADA), see for example (Ramanathan, 200I), (Janssen, 200I), (Huang, et al., 20l I). The MCDA/MADA paradigms can address the inherent complexity of managing natural resources, particularly with respect to multiple criteria, multiple stakeholders, and a lack of information (Mendoza \& Martins, 2006). In public investment decisions, however, the application of MADA and other existing assessment methods is still limited. The inflexibility, complexity and indeterminate information are major obstacles to the acceptance of any environmental assessment method (Ding, 2008). The challenge is related to broad range of environmental issues and how to include them so that it can meaningfully present and be able to compare the impact of many alternatives on the environment in order to effectively make a selection.

\subsection{PUBLIC PARTICIPATION AND INVOLVEMENT}

In recent years, there has been increasing awareness for the need for public investment decisions to move towards incorporating stakeholder participation and involvement, as these elements have been demonstrated to ensure satisfaction with the planning project and long-term commitment among key stakeholders during the implementation (Shiferaw, et al., 20I2), (Liu, et al., 2008). Most governments and, to some extent, other projects relating to public services and policy have attempted to carry out the public participation process as part of its mandate in order to involve local communities and other parties into their social programmes. It has been widely accepted that the public participation process has the potential to enable transparent and socioecologically rational decisions in public investments (Bartlett, 1990; Zuhair \& Kurian, 2016). Whereas the benefits of public participation have been widely acknowledged in both theoretical and practical terms, the role and capacity of stakeholders and local communities involved in development activities to influence decisions remain doubtful (Bawole, 2013; Nadeem and Fischer, 20I I). Much evidence in literature and practice shows that the public participation 
process is often conducted as part of the EIA, see for example (Ding, 2008; Bawole, 2013; Zuhair \& Kurian, 2016). The common method used to ensure that stakeholders and local communities are involved in the evaluation and decision is a general public hearing. Government regulations require agencies to publish public notices, conduct a minimal number of public hearings, and provide open access to public information (Handley \& Howell-Moroney, 2010). Some form of direct or representative democracy is used to obtain a maximum number of participants to make a legitimate claim of public participation (Baber \& Bartlett, 2005). For example, adapting the interviews of key informants and documentary reviews to collect opinions and include them into legal assessment requirements (Bawole, 2013). However, there is no assurance that a new project will take into account their concerns and ideas (Choguill, 1996). Ample evidence in practice shows that even in projects that have already finalised legitimate public hearings, there is still some ambiguity from local communities against the project as to what the real impacts will be and how their lives will be improved. Most attempts to involve citizens and stakeholders through the form of democracy and public hearings are viewed as superficial and rhetoric with the view to meeting legal requirements rather than a purposeful interest in eliciting input from local stakeholders (Arnstein, 1969; Bawole, 2013). The results of these methods lead to a lack of long-term positive impact on project design (Nadeem \& Fischer, 201 I; Diduck \& Sinclair, 2002). The key issue for scholars and practitioners is still to find way of making public participation and local community involvement more effective. For the stakeholders to participate meaningfully, the process must be two-way and they must remain well informed about project implications (Reed, 2008; O'Faircheallaigh, 2010). Analysis of the implications of different forms and degrees of public participation for public decision-making is still growing and has been discussed to improve the project evaluation process. A well-known evaluation of participation in development projects is the ladder of citizen participation by Arnstein (1969). There are eight levels of participation on the rungs of Arnstein's ladder which define the extent of citizens' power in determining the end product of public policy in developed countries. To apply the participation in low-income or undeveloped countries that still need developments of adequate housing and infrastructures for the population, Choguill (1996) has suggested the term "community participation" instead of "citizen participation". As in Arnstein's, an eight-rung ladder was used, but community participation was not seen only as enabling the people to influence public decisions. It was also a means for the 
people to obtain their basic needs through mutual-help initiatives which would lead to the long-term project success in the area (Ali, 2017). The levels of involvement are composed of: Empowerment, Partnership, Conciliation, Dissimulation, Diplomacy, Informing, Conspiracy and Self-management.

To this end, it can be summarised that there are many ways of achieving meaningful participation to support a public decision. It is understood that only the common methods that are acceptable for the government might not be enough to ensure a full support and success of a project. Moreover, the legal requirements do not indicate how a project must address public concerns and the public have no way of ascertaining whether their concerns are addressed (Bawole, 2013). This enlightens us to consider the levels of participation and involvement in a project and how to include it for evaluation and selection.

\subsection{CONCLUSION}

This chapter presents a review of theories and techniques available in literature for a project evaluation which is intended to answer the first research question (I.I What possible evaluation techniques and their concepts are available and what are their strengths and weaknesses?). The available and possible evaluation methods to be used for an investment project appraisal are described. They include both economic and non-economic ways of evaluation as well as their advantages and limitations for use in general and in a public investment appraisal in particular. The economic methods, especially discounted cash flow techniques (DCF), seem popular when an organisation or a policy agency wants to pursue its investment objectives. Besides an economic evaluation, noneconomic benefits should also be considered in the case of public investment projects. These non-economic approaches and methods include the measurement of the impact of an investment on society, environment and public acceptance. The measurement of the potential non-economic benefits differs from the ones that are used in economic evaluation. A selection of appropriate evaluation methods is not an easy task and it depends very much on the specific objectives and the characteristics of an organisation or a country.

In the next chapter, more approaches and techniques used for making decision of an investment project are described to answer research question I.2. This chapter and the next chapter present a full literature review that is necessary for a development of public investment project evaluation and selection. 


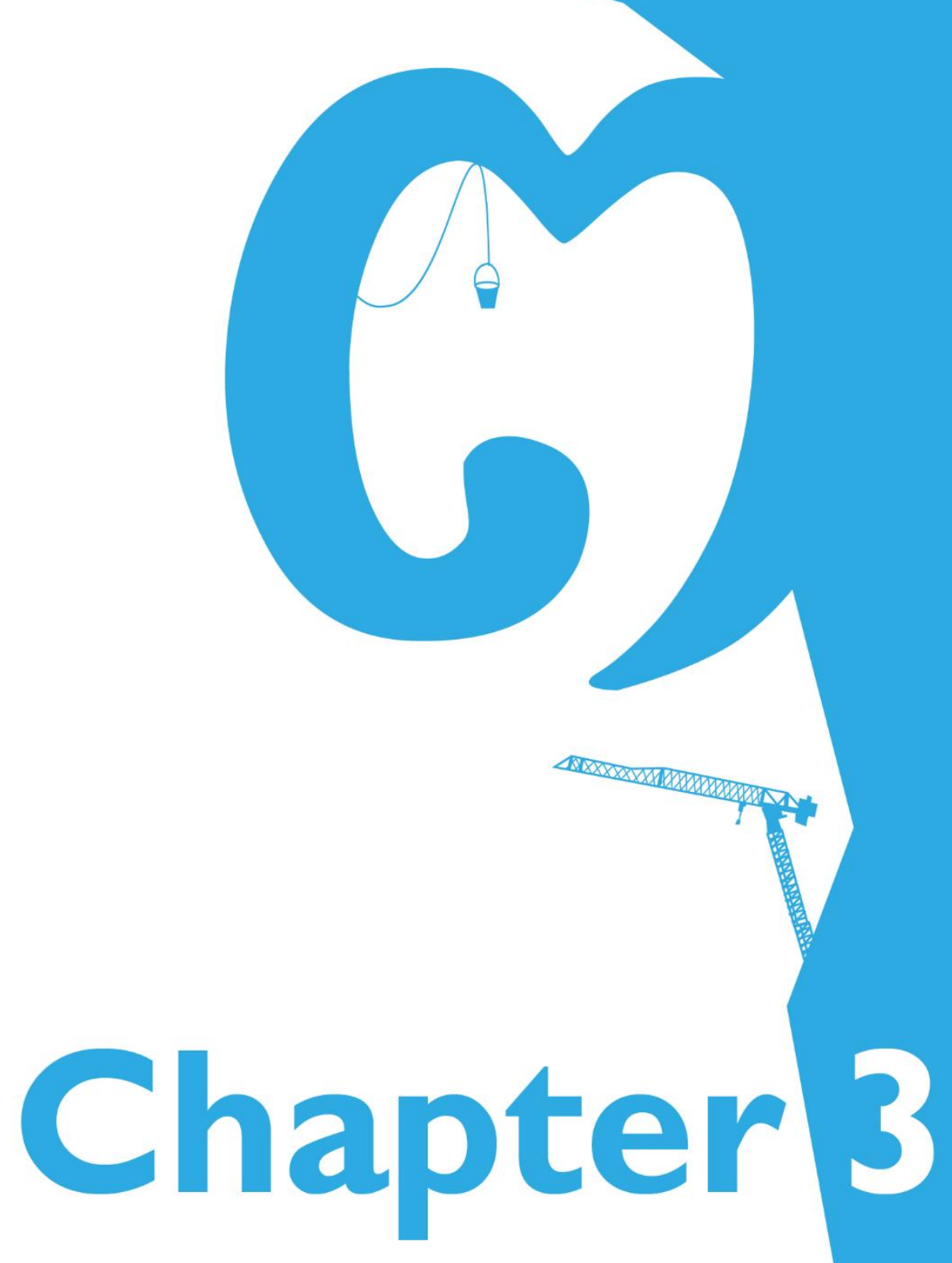




\section{THEORETICAL BACKGROUND ON DECISION-MAKING}

Decision-making is a discipline that covers a wide variety of fields of study and people have looked at it from different viewpoints. This chapter is presented to answer research question 1.2: "What relevant decision-making approaches and techniques are available for public investment project decisions and what are their respective strengths and weaknesses?". Relevant approaches and techniques that are used for making decisions about investment projects are described in this chapter. After introducing the general topic, a brief description of the main streams in decision-making is presented. In some cases, the differences between them are quite subtle and the concepts interrelate with each other. Besides providing an overview of the main streams in decision-making, some definitions are also presented to facilitate an understanding of the different approaches. The review of the different approaches to decision-making also includes a section that describes the difficulties faced by individuals and organisations in charge of making decisions.

In addition, this chapter contains a study of a decision theory known as Multiple-Criteria Decision-Making (MCDM). After the review of MCDM, some models commonly used by decision-makers are presented. These are models of choice and are not exclusive to any of the approaches of decision-making described in this chapter but used by all of them.

\section{I INTRODUCTION TO DECISION-MAKING}

Decisions are presented at every step of every thoughtful being on earth and making a decision is one of the fundamental cognitive processes of human beings (Wang \& Wang, 2004). According to Mintzberg et al. (1976), daily decisions that occur in an organisation can be called routine operating decisions which are often the routine work of the lower or middle levels in an organisation. Those decisions are more accessible to precise description and quantitative analysis than decisions at the strategic level. The complexity of the decisions grows, especially the ones involving serious consequences, as more and more criteria have to be satisfied and more constraints have to be complied with. For these complex decisions, better decision-making methods are needed. In the previous chapter, various normative evaluation techniques available in literature have been presented. However, besides techniques, more 
is needed to cope with the complexity in a decision-making process (Mintzberg, et al., 1976).

Before any further attempt to understand the process of making decisions, one must look at the variety of many of the earlier definitions of the term decision. Most researchers, such as Simon (1960); Doya \& Shadlen (2012); Holsapple (2008) state that a decision involves some kind of action to indicate a choice, a choice about a course of action, a choice leading to a certain desired objective. Harrison (1995) describes a decision as a moment, in an ongoing process of evaluating alternatives for meeting an objective, at which expectations about a particular course of action urge the decision-maker to select that course of action most likely to result in attaining the objective.

One might think that not all decisions are structured in the same way and require different rationales and levels of thought to be achieved. In this respect, Bunn (1984) categorises the process through which decisions are made as follows:

I) Intuitive decisions are those choices which individuals make almost instinctively. People just know what to do in certain situations.

2) Programmed decisions occur when a defined set of guidelines or instructions is present when making a decision.

3) Analytical decisions are those important ones about which one must think carefully.

A decision can move from one the three categories described in the paragraphs above to another if faced repeatedly by individuals or organisations. On the other hand, decisions can also develop backwards from analytical to intuitive decisions (Raftery, 1998). Complex problems encountered for the first time may call for an analytical decision. Once the decision-makers in the organisation develop experience with these type of problems, it may become feasible for the decision to be programmed on the basis of the previously constructed analytical framework. Ultimately, if sufficient experience is built up for the problem area, the decision may be made intuitively.

Elbing (1978) referred to the term decision-making as a total solving process which includes, but is not limited to the key act of choosing among alternatives. $\mathrm{He}$ used the term problem solving as a synonym for decision-making. $\mathrm{He}$ differentiates the two by stating that problem solving involves the process of 
thoughtfully and deliberately striving to overcome obstacles in the path toward a goal. He confines the term decision-making to the choice process, in which an alternative is selected from a set of options. With these definitions, Holsapple (2008) states that we can think of decision-making as a non-random activity culminating in the selection of one from among multiple alternative courses of action.

Decision-making and problem solving are not synonymous but somehow they imply each other. Decision-making often involves solving a problem and problem solving leads to making decisions. Such is the case of this study, in which the problem itself is concerned with the way decisions are made for investment alternatives. The process of selecting a particular course of action from a set of alternatives represents a problem itself and therefore, by providing a better system for making decisions, we are also providing a solution to the problem.

\subsection{APPROACHES TO DECISION-MAKING}

This section contains opinions and ideas about certain topics as seen from the viewpoint of the different approaches to decision-making. For this reason, it is considered appropriate to present some of these different approaches from the beginning.

\subsection{Behavioural decision-making}

At the most basic level of conscious decisions, every individual goes through different mental processes to reach conclusions and make decisions. It is the purpose of behavioural science in general and behavioural decision-making in particular to study and to try to understand human behaviour and its influence on the way decisions are made. One of the key points of interest is that human decision-making is mainly based on emotions on expected hedonic outcomes of the choice (Cabanac, 1992; Franken, et al., 2008). Emotions commonly influence behaviour and people unconsciously take into account their emotional reactions to possible outcomes when making decisions (Zeelenberg, 1999). Janis and Mann (1977) express the connection between emotions and behavioural decision-making by referring to our tendency to delay action and think about what might happen. Predictions and judgments always come together unconsciously in humans' minds especially when situations are unpredictable. People do not appear to follow a calculus of chance or a statistical theory of prediction. Instead, they rely on a limited number of 
heuristics which sometimes yield reasonable judgements and sometimes could lead to severe and systematic errors (Kahneman \& Tversky, 1972). Although many decision outcomes made on the basis of feelings and emotions could turn out badly, Kahneman \& Tversky (1973) maintain that these intuitive predictions make people more confident than when they follow their judgmental heuristic or the presentation of previous evidence.

\subsubsection{Organisational decision-making}

Decisions within organisations are carried out every day and, to a certain point, their study is an extension of behavioural decision-making. Behavioural science deals with individuals and small groups but its principles can also be applied to the total social system. Much of decision research concerns evaluating and developing ways for improving behaviour, in the sense of taking less time, making fewer errors and so on, thereby reflecting a strong engineering orientation (Einhorn \& Hogarth, 1988). Within organisations, people with different backgrounds have different approaches to the process of making decisions. Social scientists may find it easier to understand the reasons behind social behaviour and take it into account; whereas engineers may consider facts and figures to be the key issues of the process. They may even look at human behaviour as an obstacle that has to be sorted before solving any problem. Therefore, organisational decision-making in many cases displays many properties that are functionally similar to individual decision-making, but, at the same time, it also gives importance to facts, figures and the structure of the information so that other approaches may be used as well, such as numerical methods and mathematical models. This approach to the study of decisions has also been called managerial decision-making since "decision-making is an activity that lies at the heart of management" (Jennings \& Wattam, 1998). Decisionmaking is a vital activity of the organisation. All actions of an organisation are either explicitly or implicitly the result of management decision-making.

\subsubsection{Multiple-criteria/attributes decision-making}

A decision is naturally related to a comparison of different points of view, some in favour and some against a certain decision. This means that a decision is intrinsically related to a plurality of points of view, which can roughly be defined as criteria (Figueria et al., 2005). As a result of the decision's nature, decisionmakers often deal with problems that involve multiple, usually conflicting, criteria. These criteria can be expressed in terms of objectives or attributes. They are the parameters decision-makers use to make a choice. When the

\section{2 | Theoretical background on decision-making}


choice has to be made depending on the different characteristics of the available alternatives, multiple-criteria/attribute decision-making (MCDM/MADM) techniques are used. In contrast to MADM problems, multiple-objective decision-making (MODM) problems involve designing the best alternative given a set of conflicting objectives. MODM tends to be associated with mathematical programming, while MCDM/MDAM tend to be focused on the selection among a given set of discrete alternatives (Olson, 2008). The approach of MCDM/MDAM has been reviewed and implemented by many researchers to help them improve the quality of decisions by making the decision-making process more explicit, rational, and efficient (Lateef-Ur-Rehman, 2013). Their contributions to the approach are based on constructing numerical scores for each individual criterion to represent the degree to which one decision option may be preferred to another, so that consequently the best alternative can be selected (Mendoza \& Martins, 2006).

\subsubsection{Normative decision-making}

Analysts and experts in decision-making recognise that the study of decisions is divided into two areas for problems that involve practical applications. This division refers to decisions as they are made and decisions as they should be made, which is an issue covered by normative decision-making. Within organisations, procedures are established in an attempt to homogenise the process and aim at attaining the best results for the organisation. Normative procedures and models describe the right way to make decisions, rather than describing the way in which decisions are made (Fishburn, 1988). A normative decision-making model considers a decision to be an act of rational choice based on the organisation having a set of goals and all required information and therefore does not include the gathering of information or the implementation phase after the choice. It considers neither the person invested with the power to make the decision, with all their abilities and shortcomings, nor the context in which a decision has to be made (Zimmermann, 20I2).

Normative analysis has been regarded as unscientific by some due to its need to define values that establish a division between what should be done and what should not. Values may be regarded as the normative standards by which human beings are guided in their behaviour or in their choices among alternative courses of action. They are abstract ideals that are either positive or negative and are not tied to any particular situation or context that represents the person's beliefs. In order to establish the division mentioned 
previously, the decision-maker is forced to make value judgments about the correctness of the measures taken. The argument against this procedure is that decision-makers may be experts in their fields of study (i.e. economics, politics), but they have no expertise in making value judgments and therefore their judgment is not necessarily better than that of non-experts. The solution to this problem is presented in the next section, where the process of making decisions is discussed.

\subsection{DECISION-MAKING PROCESS}

As was outlined in section 3.I, making decisions is a process and not only a single moment in which people choose an alternative.

One of the classical decompositions of the decision-making process that is recognised in the literature as a widely accepted model has been formalised by Simon (1960). It consists of;

I) Information: data gathering to identify decision issue and set objectives;

2) Projection: identifying action alternatives and evaluating their consequences;

3) Choice: selecting the alternative that will be designated in order to act;

4) Implementation and evaluation of decision.

Elbing (1978) has suggested five steps that constitute a generic model of the total management decision-making process:

I) Perception of the environment or situation: observing and becoming sensitive to potential problem situations.

2) Diagnosis: attempting to understand what is happening in a particular problem situation.

3) Definition of the problem to be solved: identifying and stating a problem with relation to organisational and personal goals.

4) Determination of alternative methods and solutions and choice of the best solution: selecting a course of action from a series of alternatives.

5) Implementation of the chosen solution: the entire process of actualising the chosen solution.

The suggested process by Elbing (1978) is quite similar to the process suggested by Witte et al. (1972) with only one difference. Witte assumed the problem to be already evident once the decision-maker undertakes it. 
In a normative decision-making process, the first task to be accomplished is the definition of values or goals, as explained in section 3.2.4. If a normative theory specifies values or goals, then there may be no experts, as Kassouf (1970) has stated, since values are not subject to scientific analysis and therefore there is no way of telling whether they are right or wrong. Considering the importance of values, Keeney $(1992,1996)$ developed the procedure of value-focused thinking. This concept is intended for structuring decision problems, identifying opportunities and articulating and using decision-makers' fundamental values to guide and integrate their decision-making activities.

Within the decision-making process, the accepted values and goals are given to the decision- maker. Sets of goals and objectives exist within organisations so that their direction is established and, therefore, all efforts and actions are focused on the attainment of these objectives. The goals and objectives of the organisation can be developed to provide criteria (Jennings \& Wattam, 1998), or clear definitions of how the objectives are to be measured so that the organisation can assess its progress towards the achievement of its objectives.

Within the context of organisations, Harrison (1995) defined the process of normative decision-making as a cycle that includes verification and correction throughout the process by means of obtaining feedback from its agents. $\mathrm{He}$ called the components of the process functions that are defined as a group of related actions contributing to a larger action. If the process is looked at in isolation it will be perceived that it is not a cycle in the strict sense of the word, since it has a beginning and an end. However, organisations are constantly faced by the necessity to make decisions in order to survive and hence, the process is constant and never-ending. In isolation from the organisational context, the decision-making process is a cycle of refinement of the chosen actions which are carried out until they attain the objectives set in the first place. On these grounds, the functions of decision-making are:

- Setting managerial objectives. This phase requires setting the objectives to be accomplished and should be finished once these are reached.

- Searching for alternatives. This involves scanning the internal and external environments of the organisation for information.

- Comparing and evaluating alternatives. The alternatives are compared against each other by formal or informal means.

- The act of choice. The moment in which the decision-maker chooses a given course of action. 
- Implementation of decision. The actions recommended by the decision are carried out.

- Follow up and control. This function is intended to ensure that the implemented decision results in an outcome that attains the objective set initially.

This cycle can be illustrated by means of the following figure, in which the relationships between functions can be properly seen.

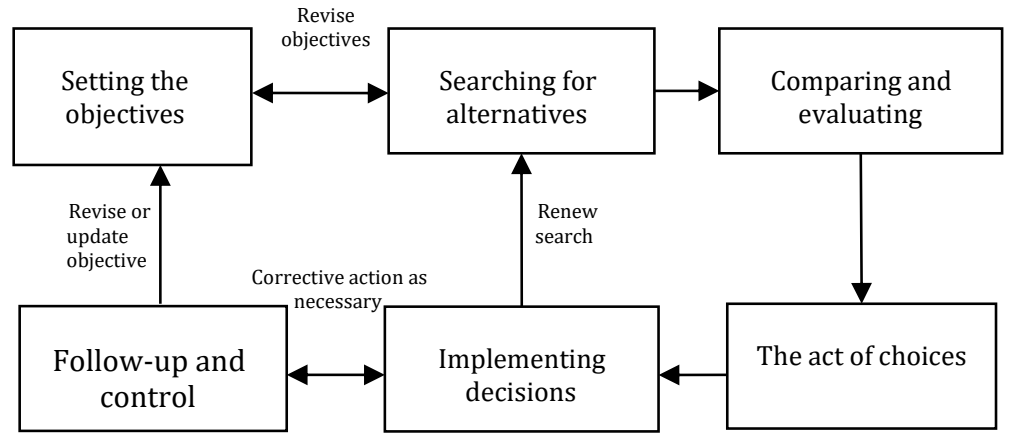

Figure 3.I The decision-making cycle (Harrison, 1995)

The relationships between the different functions are also important, since they are responsible for the recursive nature of the process. They act as a controlling device that enables the decision-maker to correct mistakes and rectify the direction of the process over its different phases.

After the objectives are set, the search for alternatives begins and, according to Mintzberg et al. (1976), three routines can occur:

- Screening. This is used first to reduce a large number of alternatives to a few feasible ones.

- Evaluation-choice. This is the opposite case to the previous one. When there are very few alternatives available, the alternatives are carefully and objectively investigated and evaluated on their factual consequences. The end-result is to select a course of action.

- Authorisation. This is used to ratify the chosen course of action, which must follow a tiered route of approval up the hierarchy before its implementation.

The process continues smoothly until it reaches the stage of implementing decisions. Up to this point, the process takes place only on paper and no 
physical action is required. At this point, the process is transferred onto the real world, where actions are required. It is now that people inside and outside of the organisation begin to notice something is happening and some difficulties and constraints may surface.

Supposing no major obstacles are faced during the implementation of actions, it is the duty of the manager to make sure everything happens as it was planned. If necessary, corrective actions are taken to rectify the direction of the project or set of actions.

Once the actions have been carried out and management considers that the objectives are attained, the situation of the organisation should be assessed to identify the improvements provided by these actions. The organisation exists within a dynamic environment and what was considered appropriate previously may not be appropriate now. For this reason, objectives have to be revised and updated to keep up to date with the changing environment.

\subsection{DIFFICULTIES IN THE DECISION-MAKING PROCESS}

As in many other cases, the process of making decisions is not a straightforward one that will take the decision-maker directly to a successful situation without any pitfalls or drawbacks. The process is hindered by a variety of factors that involve the decision-maker, the information needed, and the organisation.

The first issue that should be covered is the one concerning values in decisionmaking. Values defy measurement and quantification. An individual's value system is a pattern of values ranked according to their relative importance. Other people may disagree with an individual's ranking of values, but this ranking cannot be approved or disapproved. However, in the study of Mintzberg, Raisinghani \& Theoret (1976), it is shown that when values are ranked without in-depth knowledge about the problem or less formal types of authorisation, choices are made with an inherent bias. Additionally, the influence of values on the decision-making process can be enhanced by situational factors, such as prevalent social norms and situational uncertainty (Ravlin \& Meglino, 1987).

As a result of the different interpretations of the concept of values and value systems, it is difficult to match the decision-maker's values and their ranking to those of the organisation. In the case of group decision- making, it is even more difficult and complex, since it is not only two sets of values that have to be 
matched, but a whole group of sets (Herrera, et al., 1996); (Silva, et al., 2010). Apart from the limitations imposed on the process by the values and personality of the decision-maker, there are some additional limitations or constraints that affect the decision-making process. They are very closely interrelated, and one may even say that they overlap. According to Harrison (1995), these limitations make themselves apparent in the form of:

- Psychological limitations

- Information and its perception

- Time and cost restrictions.

\subsection{Psychological limitations}

There are unique problems related to the cognitive processes of the individual and the approach taken to deal with situations that require a decision. One problem in organisations is that every high-level decision-maker has already been assumed to have knowledge and a good deal of experience in decisionmaking. Much of that experience has been successful and the irrefutable proof is that the individual decision-maker is still in a position to exert his influence on the fate of an organisation. However, past experience in decision-making is not a guarantee that the individual will engage in rational behaviour in order to access information and have the computational capacities that are required in particular circumstances (Simon, 1955). Furthermore, learning from experiences is not something that provides positive effects all the time. People can learn errors and second-rate methods from experience and then internalise them. When questioned about the way in which a particular problem is tackled in a factory, for example, the manager who says, "That's the way we've always done it" is relying on the experience gained from previous situations without questioning if the conditions are the exactly the same, that is, without analysing.

\subsubsection{Information and its perception}

Human beings have limited information-processing capacity. There are four major areas involved in these circumstances which, according to Hogarth (1987), are:

- Perception of information

- The nature of processing

- Processing capacity 


\section{- Memory}

Perception of information is not comprehensive but selective. Not everything in the surrounding space is perceived, thus in order to make decisions, individuals must know what to select. Anticipation therefore plays a large part in what individuals actually perceive. For this reason, "people only see what they want to see" both physically and mentally.

The nature of processing. People cannot integrate a great deal of information simultaneously. For this reason, processing is mainly done in sequential fashion. Processing capacity. People do not possess intuitive "calculators" that allow them to make optimal calculations. Rather, they use fairly simple procedures, rules or heuristics in order to reduce the mental effort involved. This simplification of mental processes can lead to overlooking important facts during the decision-making process.

Memory. People have limited memory capacity. Theories support the viewpoint that memory works by a process of associations to reconstruct past events. However, human memory does not work like a computer that has all the information stored in its original form. Human memory is an active reconstruction process. Therefore, depending on which association process is used to reconstruct, memory can change.

Up to this point, the perception of information has been analysed from a behavioural viewpoint. This describes the way in which the human brain perceives information and works with it. Another fundamental aspect of information has to do with its cost. That point is presented in the following section.

\subsubsection{Time and cost restrictions}

In the activity of making a decision, especially within organisations, time always acts as a constraint that affects both managers and the process itself. It can lead to imprecision in the search for information as well as in the evaluation of the alternatives. Decision-makers feel pressurised and may make mistakes that they would not normally make. At the end of the day, decisions may be made based on intuition or hunches, since decision makers do not have enough time, resources and information to carry out a more careful analysis of the alternatives (Mintzberg et al., 1976).

Additionally, no matter how much time and effort are spent on the search for 
information that can be included in the alternatives, the search can seldom obtain all the information related to a particular subject. Consequently, the information collected will always be imperfect or incomplete. Furthermore, it is important to recognise that the cost of information rises exponentially and the value of additional units of information declines precipitously at some point (Harrison, 1995).

\subsection{MULTI-CRITERIA DECISION-MAKING}

Decision problems often involve conflict among values, because no one option best meets the decision-maker's objectives. A typical example of a decision problem is choosing a new car. An individual will not to spend a considerable amount of money on a new automobile on the basis of only one of the features (single criterion). In this respect, Goldstein and Busemeyer (1992) express that, although there is no doubt that the use of a single criterion for deciding is sometimes part of the decision-making process, the evidence obtained from real-world problems supports the use of multiple-criteria strategies instead. When selecting a car, people know that each model is characterised by a number of attributes such as mileage, passenger capacity, engine size, and even colour. The internal representation of the ideal car in the individual's mind sets the parameters and criteria that will assist him in deciding which car to buy. Due to the limitations presented in section 3.4.2, the individual's criteria will not cover all the features of the car and, by means of heuristics or rules of thumb, they will assign weights to the importance of the attributes of the car in order to make a decision.

Decision-makers in organisations deal with multiple-criteria/attribute problems all the time since they have to make choices that fulfil both the requirements or objectives set by top executives and their own requirements. The alternative chosen in the end might not be the best for a particular objective. However, it might be the one that best achieves all the objectives set by the people involved in the process within the organisation.

The need to use multiple criteria in the problem of decision-making has been recognised by experts in several fields of knowledge, such as engineering, health, and education. These ideas are also used in everybody's daily choices: even if personal decision-making problems are not structured in the same way as problems within organisations, they also involve a trade-off between different attributes. The idea behind describing the wide range of applications of decision-making with multiple criteria is to emphasise the fact that a single- 
criterion viewpoint is not adequate for most problems, including the selection of investment projects. This is due to the number of factors involved in a real-world decision problem such as this. The following paragraphs discuss multiple attributes and the role they play in the decision process.

From the previous paragraph, it can be seen that the terms multiple criteria, multiple objective and multiple attribute have been used to describe the same concepts. In literature, authors such as Figueria et al. (2005); Polatidis et al. (2006) and Mendoza \& Martins (2006) often use these terms interchangeably. Rigorously speaking, they are not the same: Multi-Criteria Decision-Making (MCDM) is the discipline that encompasses both MultiObjective Decision-Making (MODM) and Multi-Attribute Decision-Making (MADM).

However, the experience gained from the literature review, the experiments carried out and the characteristics of the projects under study has highlighted the importance of the attributes that describe the alternatives. It has been considered that the selection of investment projects is carried out based on these characteristics rather than on the objectives set by the organisation. In other words, the organisation's objectives define the set of possible alternatives, but the selection of individual projects depends on the attributes of each project.

Generally, the problems of multi-criteria/attributes decision-making are diverse, depending on the situations of organisations. Nonetheless, even with this diversity in mind, Yoon \& Hwang (1995) posit that all the problems share the following common characteristics:

Alternatives. A finite number of alternatives, from several to thousands, are screened, prioritised, selected, and/or ranked. The term "alternative" is synonymous with "option," "policy," "action," or "candidate," among others.

Multiple Attributes. Each problem has multiple attributes. A decision-maker must generate relevant attributes for each problem setting. The number of attributes depends on the nature of the problem. The term "attributes" may be referred to as "goals" or "criteria."

Incommensurable Units. Each attribute has different units of measurement. The units of one attribute may be currency and those of another may be levels of pollution or education. 
Attribute Weights. Almost all MCDM/MADM methods require information regarding the relative importance of each attribute, which is usually supplied by an ordinal or cardinal scale. Weights can be assigned directly by the decisionmaker or may be developed by numerous weight assessment methods available.

Decision Matrix. A problem can be concisely expressed in a matrix format, where columns indicate attributes considered in a given problem and rows list competing alternatives.

\subsection{CHOICES OF MODELS TO USE}

This section presents some simplified procedures for making choices based on studies by scholars such as Holloway (1979), Montgomery (1983), Bunn (1984), Payne (1993) and Yoon \& Hwang (1995).

\subsection{Dominance procedure (DOM)}

When one alternative dominates the others, the choice is easy. The dominance is established by the following definition:

If alternative $A$ is at least as preferred as alternative $B$ on all the attributes and strictly preferred on at least one attribute, it is said that alternative $A$ dominates alternative $B$.

This decision rule is quite a simple procedure, because a decision-maker should always choose an alternative which is not worse than other alternatives on any attribute and better on at least one attribute. There is, however, a limitation for this simplicity, since in most real-life decisions, we do not find an alternative which dominates all other alternatives.

\subsubsection{Heuristics}

With this strategy, the decision-maker sets a satisfactory level or cut-off for each attribute. Any alternatives that fall below the established cut-off are eliminated. There are two features that stand out from this model. The first one is that this model does not always lead to a single solution, since more than one alternative can have results above the satisfactory level. The solution offered to this drawback is to tighten the cut-offs and carry out the evaluation again if there is more than one alternative left after the first one. The cut-offs may come from different sources, such as budget, regulations or the economy of the region in which the project exists. Additionally, at a lower level, one can find the requirements set internally by companies and government 
organisations. The latter are more flexible and are determined by the decisionmaker for each particular case (i.e. minimum acceptable return from projects).

\subsubsection{The lexicographic method (LEX)}

This model first ranks the attributes in order of importance and then selects the alternative rated best on the most important characteristic. If two or more alternatives are rated equally, the next most important characteristic is used as a tie breaker.

Sometimes, this model includes the notion of "just noticeable difference"(JND). If several alternatives are within the JND of the best alternative on the most important attribute, they are considered to be tied. This version of the rule is sometimes called a lexicographic-semi-order decision rule. A point against this procedure is that it only takes into account a few attributes, if not only one, for the choice among alternatives. It also has the disadvantage of possibly eliminating alternatives with better overall performances than the one selected due to a lower score on the main attribute considered.

\subsubsection{Elimination by aspects (EBA)}

This strategy was first described by Tversky $(1972,2003)$. The EBA strategy begins with the determination of the most important attribute which is selected probabilistically, with the probability that an attribute is selected being a function of its weight or importance. After this, a cut-off is selected for the attribute and all the alternatives with values below the cut-off or "aspect" are eliminated. Tversky defined "aspect" as having a value on the selected attribute that is greater than or equal to the cut-off level. The process continues with the second most important attribute and goes on until only one alternative is left. As can be seen, this procedure is very similar to LEX, apart from two differences. The first one is that this procedure does not rank attributes in terms of importance but in terms of probabilistic discrimination. Secondly, while the LEX method accepts relatively low scores on attributes, provided they are the highest in the set, the EBA method sets minimal scores to qualify.

\subsubsection{Trade-off procedure}

Trade-off procedures have been developed to allow poor performance on one attribute to be compensated by a superior performance on another. In other words, trade-off means giving up one thing to gain another. This procedure is 
designed to find alternatives that are equivalent to the original set in all the values of attributes but one. This is achieved by means of creating equivalent alternatives. Some trade-off situations are explicit. According to Yoe (2002), a couple of examples can explain the situation. When a hot dog stand is right next to an ice cream stand and you cannot afford both, the choice of one means giving up the other. An acre of forest can be forestland or it can be cleared for development. These two examples are an explicit trade-off defined by a mutually exclusive relationship. Not all explicit trade-offs will be so easy to define, especially the ones which involve value and preferences. For example, there is no explicit trade-off between community cohesion and enhancing aquatic ecosystems. In many decision contexts, ultimate decisions involve trading off values, after which the trade-off decisions are implicit. This implicit trade-off decision can often be found in the nature of investment and planning contexts and it is even more difficult when there is a variety of value. To introduce further analysis in the context of this research, it is worth mentioning that the implicit nature of a value trade-off analysis can be fixed by the preferences of decision-makers through the specification of weights to make the analysis more transparent (Yoe, 2002).

\subsubsection{The weighted additive method}

The weighted additive method is also called Simple Additive Weighting (SAW) Method. The SAW method is probably the best known and most widely used MADM method (Yoon \& Hwang, 1995; Wang, 2015). It considers all the relevant attributes and assigns relative weights according to the importance of each one. The method develops an overall evaluation of an alternative by multiplying the importance weight by the attribute value for each attribute and adding up all the weighted values. The alternative with the highest overall score is chosen. A process such as this requires a considerable amount of information processing, since all attributes must be expressed in numerical terms. Generating numerical values for attributes can, however, be a problem when dealing with qualitative data. In areas such as economics, the problem has been tackled by means of shadow pricing, but even then, it is not an easy task. An example of the use of the SAW can be found in chapter 5, where the procedure is integrated to the rest of the proposed model for MADM within this research. 


\subsection{CONCLUSION}

This chapter provides a general overview of decision-making and the main elements that make up decision-making processes. In addition, it also reviews various approaches and models which are available and have long featured in many studies of decision-making. The goal of most decision-making approaches is to facilitate decision-makers to choose among two or more attractive alternatives. The analysis of the different approaches to decision-making also includes a section that describes the difficulties faced by individuals and organisations in charge of making decisions when trying to accomplish their objectives, which are mostly related to the limitations of human capabilities to analyse a complex decision. A complex decision is often viewed in terms of multiple objectives and criteria that a decision-maker needs to consider, which leads to an introduction of the Multiple-Criteria Decision-Making (MCDM) approach. Moreover, relevant simplified procedures are reviewed as choices of models to be used and their advantages and applicable limitations are also addressed.

The review of relevant evaluation techniques in chapter 2 and the decisionmaking literature in this chapter are very useful for the next chapters to understand and identify the practical problems in public investment project selection and how these approaches can be integrated into a decision model to deal with the pitfalls in real-life decision-making. A selection of appropriate methods both in evaluation and decision-making to be applied in this study will be further analysed and described in Chapter 5 . 


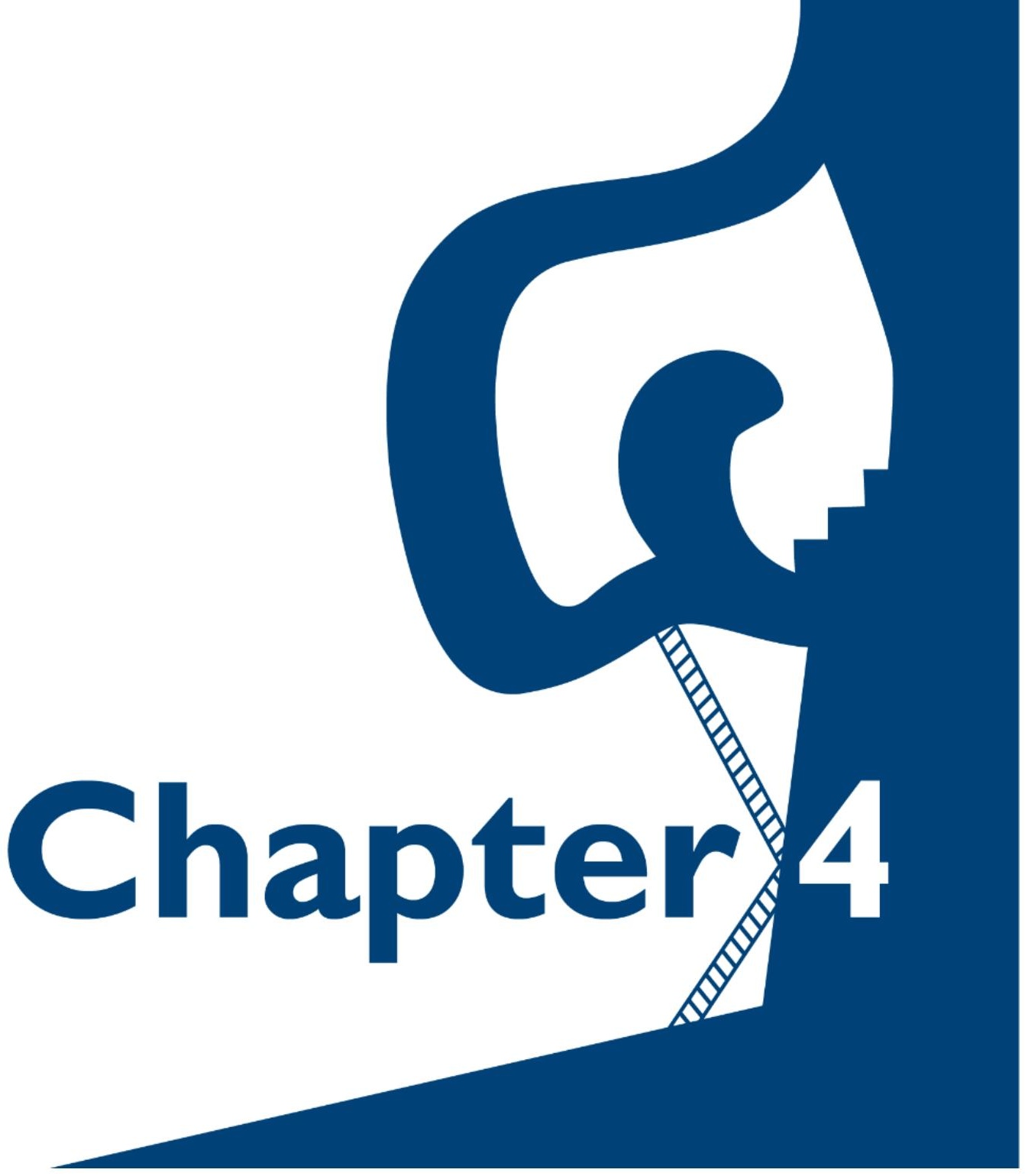




\section{PUBLIC INVESTMENT PROJECTS EVALUATION AND SELECTION IN THAILAND'}

Public investment projects, in most cases, are defined as solutions to allocate public resources in order to achieve economic growth and to meet a country's social development goals (Jó \& Barry, 2008). They involve, for example, investments in the construction of infrastructure (roads, railways, energy supply, buildings), the acquisition of equipment and technology (e.g. defence, information and communication technology) or organisational development projects. Decision-making is an essential part of the investment process. However, its practical aspects remain unstructured and lack a strong foundation (Belton \& Stewart, 2002). Especially in developing and low-income countries inequity and wide gaps between urban society and rural communities still exist, even though numerous public projects are implemented every year to improve the quality of life of the population (Fang \& Sakellariou, 2013). In many cases, such failures are caused by the way public investment projects are selected. A major challenge is related to how the evaluation and selection process, as a part of the decision-making process, is designed to guide the decision-maker through the process.

The purpose of this chapter is to answer the first research question: "What is the current state of the public investment project selection process in Thailand?". Section 4.I presents an overview of how the public investment evaluation and selection process is conducted in developing countries in general, highlighting the major problems related to the process. In section 4.2, the main focus is on analysing the current state of the investment project ecosystem in Thailand, as well as how public investment projects are evaluated and selected there. Thailand has been chosen because experience in the country has shown that

\footnotetext{
1 The previous versions of this chapter include two parts which were presented in two conferences as below:

Vajarothai, P., Al-jibouri, S. \& Halman, J.I.M. (2015) "A conceptual decision model for an investment project appraisal and selection procedure", presented in $13^{\text {th }}$ International Conference on Science and Engineering Research, December 16-17, 2015, Bangkok (Thailand).

Vajarothai, P., Al-jibouri, S. \& Halman, J.I.M. (2017) "Selection of social and sustainability criteria for public investment project evaluation in developing countries", presented in World Academy of Science, Engineering and Technology Conference Proceedings, Vol.19, May 28-29, 2017, Tokyo (Japan), p.4I56-4163.
} 
despite significant annual investments by the government invests in a large number of public investment projects to improve the situation in the country, local communities often do not experience the benefits of such investments.

Section 4.3 considers the requirements of improving the process of project evaluation and selection in the public sector by analysing the common problems and possible solutions as described in literature.

\section{I SELECTION PROCESS FOR PUBLIC INVESTMENT PROJECTS IN DEVELOPING COUNTRIES}

The project evaluation and selection process is typically carried out as part of an overall decision-making process to choose among a number of competing alternatives (Holsapple, 2008). The selection of investment projects is a term that is often used interchangeably with project evaluation. Whereas the decision-making approach considers the evaluation of alternatives as one of the stages of the whole selection process, numerous texts consider the evaluation of projects to be a process on its own, which includes the selection of the best alternative (World Bank, 1994; Mawdesley, et al., 2005).

In developing countries, a development plan is normally established by the government and public funds are invested in numerous development projects every year to improve the quality of life of their population. However, the level of equity and gaps between urban society and rural communities are still unresolved (Fang \& Sakellariou, 20 I 3; jó \& Barry, 2008; Reardon \& Vosti, 1995). This has to do with the way public investments are evaluated and selected. Research by Shiferaw et al. (20I2) indicates that the process of selecting investment projects in developing countries is often unstructured and inconsistent and that, in most cases, there appears to be no system in place to identify current needs and demands of the public to prioritise projects. Planners and decision-makers often consider the process to be a centralised system that produces a uniform outcome, instead of reflecting on the diverse needs of the various stakeholders (Besley \& Coate, 2003; Klakegg, 2009). The evaluation and selection of public investment projects is mostly complex and involves various tangible and intangible aspects that need to be understood and measured before a decision can effectively be made (Mintzberg et al., 1976; Bennet \& Bennet, 2008). The objectives of the public investment process are often aimed at guiding decision-makers to select specific types of projects that 
are intended by governments. Such guidance may be derived from a national plan or from long-term strategic objectives that are established based on a development vision or serve to solve major problems in the country (Rajaram, et al., 20I0). It is usually the basic requirements and intended achievements of the investments that can be meaningfully elaborated into several criteria in order to use as variables for comparing various project alternatives. This implies that the quality of the decision made crucially depends on the constructed criteria, which allow decision-makers to establish preference relations between alternatives (Bouyssou, 1990).

In addition, one of the most important parts of the evaluation and selection process concerns the use of efficient evaluation and decision-making techniques to appraise and select projects. Each technique has its own merits and demerits depending on the decision problems and criteria used for assessment (Ghasemzadeh \& Archer, 2000; Dey P. K., 2006). The literature study in Chapter 2 and 3 shows that there are many procedures available for evaluating projects, but the most popular ones seem to be based on the principles of Cost-Benefit Analysis (CBA). In public investment projects, the principle of $C B A$ is applied to ensure that government funds are efficiently utilised by trading off the funds invested in the projects against the social and environmental benefits they are anticipated to yield (Shaner, 1979; Gair, 2002; Pearce, et al., 2006). Even though the various techniques differ in the way various criteria (e.g. economic, social and environmental) are defined and assessed, decisions to choose between alternative investment projects are often carried out using a common monetary unit. Many studies on decisionmaking techniques have been devoted to the project selection problem. They cover several approaches, which take into account various aspects of the problem.

One well-known approach to dealing with multiple aspects and objects is the Multi-Criteria or Multi-Attribute Decision-Making (MCDM/MADM) approach, as described in Chapter 3. It has been widely used in many studies in the field of public decision-making. The aim of this approach is to combine a wide range of criteria which cannot be evaluated by the measurement of a single index of evaluation. See, for examples the studies by Gamboa and Munda (2007), AlHarbi (200I), Lateef-Ur-Rehman, 2013, and Salgado et al. (2009). MCDM/MADM can also use subjective types of evaluation which are often 
appropriate for the evaluation of intangible issues such as social and environmental impact (Belton \& Stewart, 2002).

Given the general difficulties inherent in project evaluation and selection, one can say that the process requires the development and application of many elements and mechanisms, such as evaluation criteria, the involvement of stakeholders and suitable techniques. These processes vary widely depending on the specific situation in question. The following section deals with the current situation that has been observed specifically in Thailand. The analysis will seek to highlight shortcomings in the way the process is carried out and showcases how the situation can be improved.

\subsection{CURRENT PRACTICE IN THAILAND}

To understand how public investment projects in Thailand are appraised and selected, a focused investigation was carried out. The investigation included collecting information using available documents, literature and in-depth interviews with selected experts at different levels of government. The objectives of the investigation were to identify the characteristics of the current decision process in terms of who are usually involved, the way stakeholders interact during the process, what evaluation criteria and techniques are used and how decisions are made at different levels. Based on the analysis of the collected information, shortcomings and challenges in current practice are summarised and presented at the end of this section.

\subsection{Public investment project selection procedure}

Analysis of the information collected in the interviews carried out for this study shows that the investment decision in Thailand is carried out based on what is known as the Strategic Performance-Based Budgeting System (SPBBS). This finding is also supported by a previous study by Lorsuwannarat and Buracom (20II). The budgeting system adopted by the Bureau of the Budget (BB) has been created as a mechanism to assist the Prime Minister of Thailand in making choices for allocating government budgets in a way that can maximise the welfare of citizens in the country. It is intended to be used as a tool to translate government strategies into tangible results for supporting the investment budget allocation of the government (Srithongrung, 2009; Lorsuwannarat \& Buracom, 20II). In other words, the SPBBS framework emphasises investment in projects of which the output is in accordance with national strategies, which 
is why the final selection of investment alternatives is largely influenced by this framework. Every year, the BB receives project proposals from various agencies at the project level under ministries and local agencies for budget approval, based on conformance with the national strategy. Individual project alternatives are initially evaluated at the project level and the best alternatives are selected before being sent to BB for budget approval. Large investment projects that are expected to have a high impact on environmental and social conditions compared to certain fixed regulations are required to carry out impact assessments. Generally speaking, there are no uniform guidelines for carrying out these assessments, so different public organisations use different approaches to perform them, very often leading to inconsistent results. For example, one agency may carry out a Cost-Benefit Analysis (such as IRR, NPV) of all criteria, including social and environmental factors, and compare alternatives using one common monetary unit, whilst others use different measuring units for different attributes (such as scoring method) and add them together to determine the alternative with the highest score. In case of small and medium-scale projects, other relevant variables are often used in assessments, in addition to conformance with national plans and government policy, such as objectives and goals, locations, and number of beneficiaries. Again, there are no formal assessment guidelines to support the selection of investment projects in this case.

Most proposed projects are initially screened by the BB together with the budgeting allocation committee, and some will be rejected if they do not meet the strategic budgeting criteria. The criteria used for this purpose are: (I) Strategy/Policy, which is used to check whether a project or a set of projects is in conformance with national and government strategies; (2) Function, to match each project with the mission and mandate of the agency that has initiated it to avoid redundancy; (3) Area, to define the location and benefits of a specific project to ensure that the budget will be made available to local areas. The BB subsequently organises the preliminary process by carefully checking the annual budget needed for each project and how financial performances are controlled. This includes budget planning (i.e. output-based costing, activities-based costing), procurement management and internal auditing (The Bureau of the Budget, 20I I; Lorsuwannarat \& Buracom, 20I I). This process is carried out because of the strong needs for control of government spending and the belief that effective expenditure of public resources will lead to an improved national economy and prosperity of the 
population as a whole. Finally, the projects that comply with the national strategic goals and budgeting plan are then selected and sent to the national expert committees, which make the final decision for policy approval.

\subsubsection{Shortcomings in the current procedure}

The previous section described the procedure that is currently used to evaluate and select public investments from the project level up to the strategic decision level. The procedure involves many stakeholders, but the individual public investment projects are mainly evaluated in detail at the project level by various agencies under ministries and local agencies. Technical evaluation of alternatives is performed to make sure that each of the considered alternatives achieves the investment objectives desired. Nevertheless, practice shows that the evaluation of individual investment projects at the project level differs, depending on the perception and judgment of the people working for the various agencies. The role of the people involved at the strategic level, on the other hand, is to make sure that the proposed projects conform to strategic objectives and, ultimately, to approve the required budget, often overlooking the project-level evaluation results when making their decisions. One reason for that may be the diverse ways that projects, at the project level, are evaluated and selected, which makes it difficult for the people at a higher level to understand and use those results in their decisions. Studying the current practice shows that there is no formal uniform guideline used within the various ministries and agencies to describe how public investment projects should be evaluated and compared for selection. These findings with regard to the problems of the project selection procedure in Thailand is also supported by Dabla-Norris et al. (2012), who highlight that Thailand scores very low, even among middle and low-income countries, in terms of the transparency of its selection procedure.

This study also shows that a major part of the problem in current practice is related to the criteria used to evaluate projects, as well as the subjective manner in which decisions are made by high-level officials. As indicated earlier, most investment projects are initiated at the project level, but the criteria used and the way they are measured by the various organisations vary significantly. Additionally, even though economic, environmental and social assessment criteria are required in the evaluation of high-impact projects, solely economic criteria are often used. In the comparison between alternatives, social and environmental assessments are either ignored due to their overwhelmingly descriptive form or they are converted into monetary units. 
In case of small and medium-scale projects, impact assessment is not required, with checklists and descriptive assessments often used instead. Items used in the assessments include, for example, the conformance of the project's objectives with national and government policies, the project's target area, project outputs and outcomes, and project budget spending during the project period. The checklists and descriptive criteria at the project level include the strategic main concern represented by the three criteria of Strategy, Function, and Area, as broader requirements. Another main interest of the BB is the quarterly planning of a project budget, in order to ensure the effectiveness of expenditure of public resources. This is clearly not a formal standard criterion to guide the experts and the decision-makers at the project level through evaluating the benefits and impacts of the project in a consistent and reliable manner.

Based on the data collected during this study, the most commonly used evaluation technique in Thailand to compare projects is predominantly economy-based and takes a Cost-Benefits Analysis (CBA) approach. Large projects are required to carry out impact assessments and comparisons between alternatives are mainly based on Net Present Value (NPV), Internal Rate of Return (IRR) and Benefit-Cost Ratio (B/C ratio) methods. Occasionally, Multi-Criteria/Attribute Decision-Making (MCDM/MADM) is used to help decision-makers in selecting the best alternatives. For example, qualitative scores and a ranking scale for some attribute values are sometimes used, and scores are sometimes combined with attribute weights. In case of small-scale projects, which are proposed and evaluated by local agencies, projects are mostly selected based on project costs, experiences and intuitive judgement of local decision-makers without relying on a formal assessment. Based on experience and collected data, the overall picture suggests that the current project evaluation and selection procedure used is not consistent or reliable. The main indication for this is that, although the final decision based on the budget allocation plan uses the national plan as guideline, there is plenty of evidence that indicates that the funded investment projects are not as effective in responding to the needs of local communities or Thailand's national plan. A major part of the problem boils down to how projects are evaluated and selected at the early stage. 
The shortcomings of evaluation and selection of investment projects in Thailand, as a case study that represents many developing countries, can be summarised as follows:

- The project evaluation and selection process at the project level is opaque and lacks strong foundation in its approach.

- The evaluation and selection attributes/criteria are mainly focused on economic benefits and often ignore the actual impacts of the project on environmental and social aspects for local communities and society.

- The comparison of projects is based on the use of an economic model which overlooks intangible benefits to the communities.

- In most cases, evaluation and selection are carried out without involving stakeholders and local communities and their needs.

- The process is often prone to bias because of perceived preferences without rational analysis or evidence.

\subsection{REQUIREMENTS FOR IMPORTANT CRITERIA}

The state of the current practice in Thailand described in the previous section indicates that the public investment project selection procedure is opaque and inconsistent. There is no standard guideline at the project level to evaluate and select individual public investment projects. One reason for the problem is related to the current criteria used for public decision-making.

The main intention of public investment projects is to provide public services, infrastructure, and facilities to improve overall the quality of life of the population. The current assessment of projects in Thailand, however, does not include a criterion to assess this as part of the process. The strategic criteria and economic measurements are commonly used for and primarily focused on meeting the higher strategic plans drawn up by the government. The financial feasibility of projects is also a crucial issue that BB usually considers, in particular due to the government's budget retrenchment. Moreover, the assessment of social benefits in the official process is not clear. Even though many proposed projects, especially high-impact projects, are officially required to carry out an impact assessment that includes economic, social, and environmental aspects, it is difficult to see how these factors are incorporated in the final decision.

Based on the literature about decision-making, the evaluation and selection of public investment projects is mostly complex and involves various tangible and intangible aspects that need to be understood and measured before a decision 
can effectively be made (Mintzberg et al., 1976; Bennet \& Bennet, 2008). The objectives of public investment process are often aimed at guiding decisionmakers to select specific types of projects that are intended by the government. Such guidance may be derived from a national plan or from long-term strategic objectives that are established based on a development vision or in order to solve major problems in the country (Rajaram, et al., 20I0). It is usually the basic requirements and intended achievements of the investments that can be meaningfully translated into several criteria to be used as variables for comparing various project alternatives. This implies that the quality of a decision crucially depends on the constructed criteria that allow decision-makers to establish preference relations between alternatives (Bouyssou, 1990).

In the public development context, the Organisation for Economic Cooperation and Development (OECD, 2010) suggested that the quality of evaluations could be improved by using five important dimensions of criteria, namely relevance (strategy, goal, objective), efficiency, effectiveness, impact, and sustainability. Another study by Klakegg (2009) considered the most important concerns for appraising major public investment projects to be strategic relevance and sustainability. In the approach to decision-making, project appraisal is usually addressed in terms of impact assessment, and for this reason, a standard set of criteria has emerged to assess project impacts focused on a project's sustainability, which comprises economic, social and environmental criteria (Bond, et al., 2012). Over the past decade, public awareness of environmental impact and social issues have progressively increased and, in many countries, public projects are required to carry out impact assessments of how projects affect natural environment and society (Cadena \& Magro, 2015; Haughton, et al., 2009). These effects involve ecological changes, socioeconomic (e.g. income and employment rates), physical (e.g. health and inconvenience caused), as well as impacting local populations (Garmendia, et al., 2010; Foxon, et al., 2002). On a local level, broader criteria need further detailing in order to determine how to assess them to address the needs and requirements of the various area-based conditions and the local communities within them (Reed, et al., 2006; Aksorn \& Charoenngam, 2015). Moreover, there is a need for public investment decisions to move towards incorporating stakeholder participation from both public agencies and communities. Ali (2017) indicates that coordination and participation of stakeholders should be considered at the early stage of public decisions to enhance a project's long-term sustainability. This aspect is also considered as an important measure of project success. 
Although all relevant criteria mentioned above are important and widely used in project evaluation and selection procedures, each of these criteria are often viewed, measured and used differently.

The solution, therefore, is for public decisions to seek to explore projects from several points of view, considering more than just high-level decision preferences. This section aims to gather all criteria from literature and practical criteria relevant to public investment project evaluation, as well as all methods that are not used but have been suggested by users during data collection about the current problem. Subsequently, the summary list of criteria was presented to a number of experts at the project level in Thailand in order to prioritise them for use in public investment project decisions.

At the end of this section, the prioritised criteria are analysed and assigned into several stages within the decision-making process of public investment projects in Thailand. Despite the importance of other stages, only the criteria at the stage of project evaluation and selection (at project level) will be considered for the next step as the main focus of this study.

\subsection{Collection of criteria for public investment decision}

During data collection about the problems inherent in the current process, stakeholders from the project-level organisations agreed on the suitability of the strategy-based decision in selecting the type of investment that can produce overall benefits for the whole country. However, such benefits may take a very long time to be realised or to produce any impact on people's lives. Immediate impacts and area-based requirements of local communities are also important and need to be addressed. Those requirements and the projects related to them would best be proposed through community involvement in the process. Besides such involvement, a working synergy among investment projects within a region or a certain territory is also suggested by some of them and is supported by studies such as those by Millar (1988) and Cho \& Shaw (2013). In these publications, working synergy is created to enhance advantages accruing from a relation of one project to other proposed projects, for example developing a working collaboration between two or more projects to let them share the same outcome. In the current procedure in Thailand, many local projects are proposed based on community hearings with local governments, where local communities explain their problems, express opinions, and discuss their requirements and solutions. Interviewed local experts stressed that although these hearings are seen as very important venues for community 
involvement in the decision-making process, most of the projects proposed on the basis of these hearings are not considered in the selection decisions. This might be due to exclusion of outcomes from local community participation and involvement which can be translated into relevant criteria to influence the decision.

Diverse evaluation and selection criteria found in literature in this section, in Chapter 2, in practice, as well as new criteria suggested by experts are summarised in Table 4.I. The summary list comprises nineteen possible criteria related to public investments split into six categories; economic, social, environmental, long-term support, strategic, and others.

Table 4. I: Criteria list for public investment decision

\begin{tabular}{|c|c|c|}
\hline Criteria/Attributes & Sources & Descriptions \\
\hline \multicolumn{3}{|l|}{ Economic } \\
\hline $\begin{array}{l}\text { A. Economic viability } \\
\text { (cost-effectiveness/ cost- } \\
\text { benefit/return on } \\
\text { investment/ NPV) }\end{array}$ & $\begin{array}{l}\text { OECD (20I0); Lee Jr. } \\
\text { (2000); Medaglia, et al. } \\
\text { (2008); Tsamboulas } \\
\text { (2007); Liu, et al. (2008) }\end{array}$ & $\begin{array}{l}\text { The potential impact of the proposed } \\
\text { project on economy or economic } \\
\text { activities in the country. This includes } \\
\text { comparison between costs and outcomes } \\
\text { of the project to society. }\end{array}$ \\
\hline B. Fiscal effects & $\begin{array}{l}\text { Millar (I 988) } \\
\text { ** }\end{array}$ & $\begin{array}{l}\text { Effects of the project on the annual } \\
\text { budgeting in the following year. These } \\
\text { include, for example, increasing operating } \\
\text { and maintenance costs. }\end{array}$ \\
\hline C. Financial feasibility & Medaglia, et al. (2008) & $\begin{array}{l}\text { Checking project activities and bill of } \\
\text { quantities budget to check their feasibility } \\
\text { in accordance with fiscal limitations. }\end{array}$ \\
\hline \multicolumn{3}{|l|}{ Environmental } \\
\hline $\begin{array}{l}\text { D. Disruption and } \\
\text { inconvenience caused } \\
\text { during constructions }\end{array}$ & Cadena \& Magro (20I5) & $\begin{array}{l}\text { Inconvenience caused by the project to } \\
\text { local people. }\end{array}$ \\
\hline $\begin{array}{l}\text { E. Natural resources and } \\
\text { environmental } \\
\text { disturbance/impact }\end{array}$ & $\begin{array}{l}\text { Garmendia, et al. (20l0); } \\
\text { Haughton, et al. (2009); } \\
\text { Foxon, et al. (2002) }\end{array}$ & $\begin{array}{l}\text { Influence environmental quality of the } \\
\text { area to foster a balance between } \\
\text { development and conservation. This } \\
\text { affects wide ranges of natural resources, } \\
\text { i.e. water, air, land use, etc. }\end{array}$ \\
\hline \multicolumn{3}{|l|}{ Social } \\
\hline $\begin{array}{l}\text { F. Effects on local } \\
\text { employment and } \\
\text { economic activities }\end{array}$ & $\begin{array}{l}\text { Haughton, et al. (2009); } \\
\text { Cadena \& Magro (20I5); } \\
\text { Garmendia, et al. (2010) }\end{array}$ & $\begin{array}{l}\text { Whether the project will have influence } \\
\text { on unemployment or people's income. }\end{array}$ \\
\hline $\begin{array}{l}\text { G. Impacts on quality of } \\
\text { life in the target area }\end{array}$ & Haughton, et al. (2009) & $\begin{array}{l}\text { Improving public services and facilities } \\
\text { which directly affects standard of living of } \\
\text { local people. }\end{array}$ \\
\hline H. Distributional effects & Cadena \& Magro (20I5) & $\begin{array}{l}\text { Groups of people affected by the project. } \\
\text { Who pays? and who benefits? }\end{array}$ \\
\hline $\begin{array}{l}\text { I. Area-based } \\
\text { requirement/priority }\end{array}$ & $\begin{array}{l}\text { Liu, et al. (2008); } \\
\text { Haughton, et al. (2009); } \\
\text { Raymond, et al. (2009); } \\
\text { Aksorn \& Charoenngam } \\
\text { (20I5); Garmendia, et al. }\end{array}$ & $\begin{array}{l}\text { Addressing the specific problems and } \\
\text { different needs in the area of the project. }\end{array}$ \\
\hline
\end{tabular}




\begin{tabular}{|c|c|c|}
\hline Criteria/Attributes & Sources & Descriptions \\
\hline & $\begin{array}{l}(20 I 0) \\
* *\end{array}$ & \\
\hline \multicolumn{3}{|l|}{ Long-Term Support } \\
\hline J. Public participation & $\begin{array}{l}\text { Garmendia, et al. (20I0); } \\
\text { Aksorn \& Charoenngam } \\
(2015)\end{array}$ & $\begin{array}{l}\text { Organising public participation activity in } \\
\text { general to choose the relevant projects, } \\
\text { this includes, for example, community } \\
\text { hearing, questionnaire. }\end{array}$ \\
\hline $\begin{array}{l}\text { K. Stakeholder } \\
\text { acceptance }\end{array}$ & $\begin{array}{l}\text { Liu, et al. (2008); } \\
\text { Shiferaw, et al. (20I2) }\end{array}$ & $\begin{array}{l}\text { Agreement and support from various } \\
\text { stakeholder groups on a project. }\end{array}$ \\
\hline L. Project synergy & $\begin{array}{l}\text { Millar, I988; Cho \& Shaw } \\
(2013) \\
* *\end{array}$ & $\begin{array}{l}\text { Advantages accruing from a relation of } \\
\text { one project to other proposed projects. }\end{array}$ \\
\hline $\begin{array}{l}\text { M. Community } \\
\text { cooperation and } \\
\text { collaboration }\end{array}$ & $\begin{array}{l}\text { Aksorn \& Charoenngam } \\
(2015) ; \text { Foxon, et al. } \\
(2002) \\
\text { ** }\end{array}$ & $\begin{array}{l}\text { Project working group or collaboration } \\
\text { with local communities in the area. }\end{array}$ \\
\hline $\begin{array}{l}\text { N. Incorporation of local } \\
\text { or indigenous knowledge }\end{array}$ & $\begin{array}{l}\text { Aksorn \& Charoenngam } \\
(20 \mid 5)\end{array}$ & $\begin{array}{l}\text { The utilisation of information and } \\
\text { knowledge accumulated from area-based } \\
\text { conditions and people/experts living and } \\
\text { experiencing the problems in the area. }\end{array}$ \\
\hline \multicolumn{3}{|l|}{ Strategic } \\
\hline $\begin{array}{l}\text { O. Relevance to } \\
\text { strategies, goal, objectives }\end{array}$ & $\begin{array}{l}\text { OECD (20I0); } \\
\text { Tsamboulas (2007); Liu, } \\
\text { et al. (2008); Klakegg } \\
(2009)\end{array}$ & $\begin{array}{l}\text { Conformance of the project with } \\
\text { strategies, goals, plans of national, } \\
\text { government and agency. }\end{array}$ \\
\hline P. Functionality & Tsamboulas (2007) & $\begin{array}{l}\text { This is to match each project with the } \\
\text { mission and mandate of the agency that } \\
\text { has initiated it to avoid redundancy. }\end{array}$ \\
\hline \multicolumn{3}{|l|}{ Others } \\
\hline $\begin{array}{l}\text { Q. Relation to success- } \\
\text { case projects }\end{array}$ & $* *$ & $\begin{array}{l}\text { Extending/applying/adopting results or } \\
\text { knowledge from past successful projects. }\end{array}$ \\
\hline $\begin{array}{l}\text { R. Readiness in term of } \\
\text { constructions }\end{array}$ & Tsamboulas (2007) & $\begin{array}{l}\text { The preparedness to undertake the } \\
\text { project as soon as possible to ensure that } \\
\text { it will be delivered on time, for example; } \\
\text { budget plan, technology acquisition, } \\
\text { project location. }\end{array}$ \\
\hline $\begin{array}{l}\text { S. Amount of uncertainty } \\
\text { and risk }\end{array}$ & $\begin{array}{l}\text { Millar (I988); Garmendia, } \\
\text { et al. (2010) }\end{array}$ & $\begin{array}{l}\text { Estimating the amount of uncertainty and } \\
\text { risk probability of negative consequences } \\
\text { during undertaking a project }\end{array}$ \\
\hline
\end{tabular}

** Criteria suggested by project-level experts during the interview

In fact, the number of criteria normally used in literature and practice is less than the number shown in Table 4.I. Although there is no consensus on how many evaluation criteria are appropriate, it has been argued that, due to the limitations of human cognition and in order to avoid a lack of information input into the evaluation process, it is advisable that the number of criteria should not be too large or too small (Bouyssou, 1990; Tsamboulas, 2007). For this reason, the list of criteria shown in Table 4.1 must be cut down to a limited number, representing the most relevant ones. 


\subsubsection{Method}

The most relevant criteria represent the interests of the various stakeholders affected by an investment project. To achieve the purpose of this study, the participation of experts and project analysts from various agencies at the project level involved in the process is considered to be crucial. For this purpose, a survey was carried out, combined with in-depth interviews with experts and analysts from many agencies, representing both central agencies and local government organisations at the project level. Officials from the central agencies answer directly to the various ministries, which, in turn, answer to higher-level decision-makers. Local officials have authority in local projects and work closely with local communities, which is why it is important to listen and collect information on the subject from them.

The first step in collecting the information was carried out through conducting in-depth interviews with a small number of targeted experts to ensure that the questions, criteria, and short descriptions of what they mean were clearly understood. Following this, a survey was sent to more experts. In the first instance, nineteen criteria were provided in a list from which experts could select only five critical criteria that they thought to be most important for evaluating public investment projects in Thailand. Subsequently, they were asked to rank the selected five criteria from I - 5 (I being least important and 5 being most important). They were also asked to provide opinions about the selected criteria and to suggest additional criteria to the list if necessary. The rank also represents the score given to each criterion and hence rank 5 means a score of 5 and rank $I$ is given a score of $I$. This means that each expert assigns 15 scores.

The total importance score for each criterion $j$ is calculated by adding all the scores $R$ ( $($ to 5 ) given to the criterion by all the respondents. Criteria that are not chosen by the respondents are given a score of zero. The total score for each criterion is determined as:

$$
S_{j}=\sum_{i=1}^{n} \boldsymbol{R}_{i j}
$$

where $S_{j}$ is the total importance score of criterion $j$ and $R_{i j}$ is the rank (score) given by respondent $i$ for the criterion $j$. 


\subsubsection{Result}

There were 52 respondents in total; 26 people from central agencies and 26 people from local organisations, each of whom had experience with the project assessment and selection process. Based on the list of nineteen criteria, an additional criterion was suggested during the survey by a number of respondents, which was then added to the list, namely 'Readiness in term of operating support' (item $\mathrm{T}$ ), representing the readiness of an agency and a working team to operate a project in terms of available capability.

780 importance scores were given by 52 respondents in total and the scores for each criterion are shown in Table 4.2. The list of criteria is ranked from the highest to lowest.

Table 4.2: Importance ranks of criteria selected by experts

\begin{tabular}{|c|c|c|c|c|}
\hline No. & Criteria & Rank & Aspects & Scores \\
\hline O. & Relevance to strategies, goal, objectives & $\mathrm{I}$ & Strategic & 119 \\
\hline M. & $\begin{array}{l}\text { Community cooperation and } \\
\text { collaboration }\end{array}$ & 2 & Long-term Support & 79 \\
\hline $\mathrm{I}$. & Area-based requirement/priority & 3 & Social & 74 \\
\hline E. & $\begin{array}{l}\text { Natural resources and environmental } \\
\text { disturbance/ impact }\end{array}$ & 4 & Environmental & 67 \\
\hline A. & Economic viability & 5 & Economic & 57 \\
\hline $\mathrm{H}$. & Distributional effects & 6 & Social & 51 \\
\hline G. & $\begin{array}{l}\text { Impacts on quality of life in the target } \\
\text { area }\end{array}$ & 7 & Social & 44 \\
\hline L. & Project synergy & 8 & Long-term Support & 41 \\
\hline J. & Public participation & 9 & Long-term Support & 40 \\
\hline C. & Financial feasibility & 10 & Economic & 36 \\
\hline F. & $\begin{array}{l}\text { Effects on local employment and } \\
\text { economic activities }\end{array}$ & II & Social & 32 \\
\hline R. & Readiness in term of construction & 12 & Others & 26 \\
\hline P. & Functionality & 13 & Strategic & 23 \\
\hline Q. & Relation to success-case projects & 14 & Others & 23 \\
\hline B. & Fiscal effects & 15 & Economic & 17 \\
\hline D. & Disruption and inconvenience & 16 & Environmental & 16 \\
\hline $\mathrm{N}$. & $\begin{array}{l}\text { Incorporation of local or indigenous } \\
\text { knowledge }\end{array}$ & 17 & Long-term Support & 14 \\
\hline K. & Stakeholder acceptance & 18 & Long-term Support & 12 \\
\hline S. & Amount of uncertainty and risk & 19 & Others & 5 \\
\hline $\mathrm{T}$. & Readiness in term of operating support & 20 & Others & 4 \\
\hline & \multicolumn{3}{|c|}{ Total scores } & 780 \\
\hline
\end{tabular}


According to Table 4.2, the figures and ranking positions show that the highest marks are given at to 'Relevance to strategies' (I19), making it the most critical criterion. Second and third place belong to 'Community cooperation and collaboration' and 'Area-based requirement/priority', which obtained a score of 79 and 74 , respectively.

The highest-ranking criterion, 'Relevance to strategies', belongs to the strategic domain. This criterion matches the basic criteria that the BB and other agencies in Thailand used as one of the broad checklist criteria, namely Strategy/Policy. Besides the strategic domain, the top 10 most important criteria selected by experts highlight attention to the economic, social, environmental and long-term support aspects of a project, while the criteria belonging to the others domain were chosen to be the least relevant.

As can be seen in the survey results, the five most important criteria belong to five different domains, making the 5 most important domains Strategic, Economic, Social, Environmental and Long-term support. The main criteria related to these domains are selected in the following order;

(I) Relevance to strategies (Strategic)

(2) Community cooperation and collaboration (Long-term support)

(3) Area-based requirement/priority (Social)

(4) Natural resources and environmental disturbance/impact (Environmental)

(5) Economic viability (Economic)

(6) Distributional effects (Social)

(7) Impacts on quality of life in the target area (Social)

(8) Project synergy (Long-term support)

(9) Public participation (Long-term support)

(10) Financial feasibility (Economic)

(II) Effects on local employment and economic activities (Social)

These results present the criteria in terms of economic and financial assessments, which are in fifth and tenth place with 57 points for 'Economic viability' and 36 points for 'Financial feasibility'. These criteria are always used in the current procedure at the project level and are also presented as the criteria that the BB is most concerned with.

The social domain is also shown rank highly, with three social criteria occupying third, sixth and seventh place, respectively. 74 points were given to 'Area-based 
requirement/priority' , $5 \mathrm{I}$ to 'Distributional effects' and 44 scores to 'Impacts on quality of life in the target area'.

- The first one (Area-based requirement), which was chosen as the most important social criterion by the experts, is related to one of the checklist criteria used by the BB, namely the Area criterion. However, the 'Area-based requirement' in the criteria list provides more meaningful details to specify problems in a target area for a social evaluation than the Area criterion used by the BB.

- Two criteria, Distributional effects and Impacts on quality of life, were also selected, presenting a new perspective on the part of Thai experts relating to the social impact of a public investment project. Based on their opinions in the survey, most of them consider that social impacts require long-term indicators which are related to local community wellbeing and gradually positive changes in living conditions of targeted beneficiaries. Local well-being and quality of life (QoL) in developing countries, as mentioned in studies by Veenhoven (199I), Camfield (2012), for instance, are related to income and poverty measures, which is why it is inevitable to include a criterion for these matters.

- Another social criterion on the list is 'Effects on local employment and economic activities'. Although it is in eleventh place (32 points), the score is very close to being tenth. Moreover, this criterion represents measuring material characteristics in a society such as money and property, which are two of the instruments for assessing social changes and impact (Casas, 20II). For this reason, this criterion should not be removed from the selected list.

Furthermore, the opinions of the experts during data collection tended to demonstrate an interest in involving local communities and their satisfaction with a project when discussing project impact. These opinions show a selection of criteria by them in the long-term support domain, which rank highly. The first criterion in this domain is ranked second (79 points), namely 'Community cooperation and collaboration'. The common 'Public participation' also comes in in ninth place ( 40 points), as a general semblance of participation is often required by the government. The new criterion suggested and chosen by the experts to promote long-term support is 'Project synergy' which ranks eighth (4I points). This criterion involves the relation of one project to other proposed projects. In other word, the benefits of a project will be increased when it is implemented together with other interrelated projects. Despite individual project selection 
at the project level, this indicates a need for selecting a set of projects, which should be done at a programme level or be based on a policy decision.

According to the criteria ranks, only one criterion related to the environmental domain stands out, namely 'Natural resources and environmental disturbance' which came in fourth with 67 points. This criterion focuses on measuring the overall impacts of a project on existing natural resources and the balance of the environment, rather than on specific environmental issues, which may vary from project to project.

\subsubsection{Discussion}

A basic premise of public investments is that the criteria used in the decision should meaningfully represent various requirements and perspectives, not only from the policy decision-maker's point of view, but also from the perspectives of other stakeholders.

The discussion centres on analysing all important criteria selected and finding their appropriateness to the evaluation and selection of public investment projects in Thailand. The public investment decision-making process in this country is complex and involves several decision stages at various levels of public organisations. Based on the decision-making process carried out in practice in Thailand, this analysis shows 3 stages involving the selected criteria along the entire process, namely the pre-screening stage (at the budgeting level by the $\mathrm{BB}$ ), the individual project evaluation and selection process (at the project level), and the policy decision (at the strategic or policy level).

Keep in mind that this study focuses on the individual project evaluation and selection process (at the project level), which is part of the whole public investment decision-making process. Although all important criteria from the previous section are selected by the experts as requirements for the entire public decision process in Thailand, the focus is more on which criteria are suitable for the individual project evaluation and selection process (at the project level) and how they can be applied to make a decision.

The summary of the analysis is illustrated in Table 4.3 , followed by the discussion.

Pre-screening stage: The criteria at this stage are used as a cut-off tool for screening which proposed projects should or should not be included based on 
their relevance to strategy, regulation, and other critical constrains. According to the selected criteria list and the interviews, most experts at project-levels organisations agreed on the suitability of the strategy-based criteria for project selection, because they represent the direction of development for the whole country. The criteria selected by them are therefore presented first as being strategically relevant. The selected criteria in this aspect are 'Relevance to strategies' and 'Financial feasibility' which emphasise considering projects that are relevant to the national strategic plan as well as being relevant to the requirements of the budgeting plan and management of the $\mathrm{BB}$. These criteria are most important and if a project does not satisfy these criteria, it will be eliminated at the early stage of the evaluation to reduce the overall number of projects. The selection of these two criteria by the experts shows the strong strategic requirements imposed by the $\mathrm{BB}$ and the government to control the investment direction of the country. Besides these two criteria, the criterion 'Public participation' is also classified as a part of the pre-screening stage. It is chosen by many experts because it is presented as a legal requirement to meet a general semblance of participation and could thus be one of the important conditions that a project needs to comply with first.

Table 4.3: Analysis of selected criteria for different stages of public investment decision

\begin{tabular}{|l|l|l|}
\hline \multicolumn{1}{|c|}{$\begin{array}{c}\text { Decision } \\
\text { stages }\end{array}$} & \multicolumn{1}{|c|}{ Criteria } & \multicolumn{1}{|c|}{ Aspects } \\
\hline \multirow{2}{*}{$\begin{array}{l}\text { Pre-screening (cut- } \\
\text { off level) }\end{array}$} & Relevance to strategies & Strategic \\
\cline { 2 - 3 } & Financial feasibility & Economic \\
\cline { 2 - 3 } $\begin{array}{l}\text { Individual } \\
\text { project } \\
\text { evaluation and } \\
\text { selection }\end{array}$ & Public participation & Long-term support \\
\cline { 2 - 3 } & Economic viability & Economic \\
\cline { 2 - 3 } & $\begin{array}{l}\text { Area-based requirement/priority } \\
\text { Impacts on quality of life in the target } \\
\text { area }\end{array}$ & \multirow{2}{*}{ Social } \\
\cline { 2 - 3 } & $\begin{array}{l}\text { Effects on local employment and } \\
\text { economic activities }\end{array}$ & \\
\cline { 2 - 3 } & $\begin{array}{l}\text { Natural resources and } \\
\text { environmental disturbancel impact }\end{array}$ & Environmental \\
\cline { 2 - 3 } & $\begin{array}{l}\text { Community cooperation and } \\
\text { collaboration }\end{array}$ & $\begin{array}{l}\text { Long-term } \\
\text { support }\end{array}$ \\
\hline Policy decision & Project synergy & Long-term support \\
\hline
\end{tabular}


The individual project evaluation and selection at project level: the analysis based on the survey indicates that four aspects are necessary to be included to measure the impacts and benefits of public investment projects: Economic, Social, Environmental and Long-term support aspects.

- The economic aspect includes the criterion 'Economic viability' to measure project benefits in terms of money, where its benefits are compared against costs. A project with higher monetary benefits is usually presented as the better alternative. As presented in the current procedure, economic measures such as Cost-Benefit Analyses (CBA) are often used to satisfy this aspect.

- The social aspect involves criteria related to various social variables, namely 'Area-based requirement/priority', 'Distributional effects', 'Impacts on quality of life in the target area', and 'Effects on local employment and economic activities'. The definitions about the QoL and economic activities in the project area can be seen in many studies related to social and public projects, such as Bauer, 1966; Garmendia, et al. (2010); Casas, 2011, as effects on socio-economic and social well-being dimensions such as increasing average income, increasing the number of jobs, improving healthcare and education of local people. Moreover, there is also a relationship between the two variables; 'Area-based requirement priority' and 'Distributional effects'. This is because in order to take the requirements of project area into consideration, it is also necessary to consider how the project's impacts will be distributed over the various groups within the area. The priority of requirements means choosing the right project that has more positive and direct impact on the conditions of the most disadvantaged groups in the country. An investment project that brings benefits to those disadvantage people will, in this case, have a higher priority. This indicates a need for a deeper measure of a project in social situation in the country. The experts also expressed the opinion that including these new criteria in the evaluation of a project can be used as long-term social indicators for the post-assessment phase after the project has been completed.

- The environmental aspect of project evaluation presents one criterion: 'Natural resources and environmental disturbance/impact'. This criterion is selected by most experts and reflects the increasing concern for how projects affect thee natural environment. Mandatory environmental 
regulations also require that the environmental impact of all high-impact projects be assessed. Projects with a greater impact on the environment will not be prioritised as highly.

- The long-term support aspect indicates the need for public investment decisions to move towards incorporating stakeholder participation and involvement. There is only one criterion included in the individual project evaluation and selection stage, namely 'Community cooperation and collaboration'. Whereas the benefits of public participation are well known, the role and capacity of stakeholders and local communities involving development activities and influence decisions remains unknown. The higher scores by the experts on 'Community cooperation and collaboration' seem to suggest another way of participation that includes purposeful interest from local communities. This criterion presents advanced public and community participation, which is not seen only as being a means to enable people to influence decisions in a political arena, but as a means to obtain their mutual help initiatives and possibly with other outside help. The experts' opinions on this criterion support the notion that if a project is supported by strong collaboration and communication among various stakeholders involved in a project, it will have a higher chance of long-term success.

Policy decision: In current practice, after individual projects have been selected at the project level, the projects are collected and assessed for budget approval and implementation. This stage could be called the final decision stage. It is always organised by the strategic national committees together with the BB. Apart from the criteria described above, the last criterion is 'Project synergy'. This criterion is also recommended by many experts who have experience in high-level project selection. Synergy can be measured through benefits accrued from a relationship of one project to other proposed projects. For example, a regional project and one or more local projects in the affected area can be selected together as interrelated projects (a set of projects) in order to share knowledge and achievements among relevant project agencies. As a result, they can save costs, resources and time and subsequently can also help each other to reduce the negative impact of their projects. With regard to its functionality, the analysis suggests using this criterion for policy-level selections, where various selected individual projects from the project level are gathered and can be assessed together to satisfy a government policy programme The opinions of experts on the use of this criterion, besides its definition, also point to an 
attempt to enhance working collaboration among public agencies and government officials to reduce disruption during the construction and implementation phase due to conflicts between related projects.

The discussion can be concluded by emphasising the scope of research, which tends to improve the individual project evaluation and selection process despite the importance of the pre-screening and programme selection stages. The suggested set of criteria in the individual project evaluation and selection stage includes the aspects of Economic, Social, Environmental and Long-term support, which will be further applied in the development of a decision model to evaluate and select public investment projects. The analysis based on the survey reveals the requirement of many new criteria in Social and Long-term support aspects to be applied for public investment project evaluation and selection. The analysis also provides a complete set of criteria for the entire public investment decision-making process in Thailand.

\subsection{CONCLUSION}

This chapter provides the answers to the question about the current state of the selection of public investment projects in Thailand. The analysis of the current situation in Thailand demonstrates several main shortcomings in the current procedure. It indicates that the procedure is opaque and lacks a strong foundation. There are no standard guidelines available that clearly describe how public investment projects should be evaluated and compared for selection. Moreover, the problems are also related to which criteria are used, as they are generally focused on economic benefits and ignore other important evaluation aspects, such as impact on society and environment. Nor does it consider potential approval by the local community. With regard to the problems, there is a need to improve the current procedure for project evaluation and selection, adding transparency and rationality. The process needs to be structured in a systematic way and the evaluation and selection of a project should include all important aspects that a government is supposed to meet for the country's development.

This chapter also suggests the most important criteria and aspects which are suitable for the individual project evaluation and selection. These criteria have been selected by various experts and the results indicate diverse requirements that public investment projects in Thailand should be assessed on, not only a single economic one. The selected criteria by experts include 7 criteria in 4 
aspects which are the Economic, Social, Environmental and Long-term support aspects of a project investment. In addition to the economic aspect, which is often used in literature and in current practice, many new criteria which are not yet used in the current procedure were selected to improve the current procedure. These criteria belong to the social and long-term support aspects. The new selected criteria indicate a need for a detailed measure of a project on the social aspect. The experts also experienced the need to also include the involvement of stakeholders and local communities in the evaluation of an investment project. This will enhance a project's chances of long-term success. 


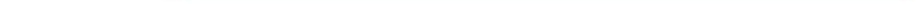




\section{AN INTEGRATED DECISION MODEL AND METHODOLOGY}

The previous chapters introduced the theoretical background and required criteria for the development of a new methodology for the selection of public investment projects. An analysis was carried out on traditional appraisal techniques, discussing their advantages and disadvantages. The analysis revealed that the selection methods that are currently used fail to include important environmental, social and long-term support evaluation criteria.

The purpose of this chapter is to answer the third research question: "How to incorporate the various concepts and techniques from different disciplines into one integrated decision model to improve the project evaluation and selection procedure?". Therefore, the main focus of this chapter is to develop and propose an integrated decision model and its methodology for the evaluation and selection of public investment projects, which will henceforth be referred to as the IDM.

Section 5.1 starts with the introduction of the objectives to be attained by means of the IDM. Section 5.2 explains the research steps that have been followed to develop the IDM. Section 5.3 describes the main steps of the IDM. In section 5.4, the economic, social, environmental and project support criteria that will be included in the IDM are detailed. Section 5.5 explains how the evaluation criteria are integrated and weighted in the IDM as the general decision framework within which projects are analysed and selected. The techniques used in the IDM are also discussed in the context of these categories.

The structure of the methodology and the information required to perform an IDM are presented in sections 5.6 and 5.7 respectively.

\section{I OBJECTIVES OF THE MODEL}

In addition from the objectives of the study stated in chapter I, it relevant to define here the objectives to be realised by developing of the integrated decision model for public investment project evaluation and selection (IDM). These can be stated as follows:

- To reflect by means of the methodology the importance of the noneconomic factors in the project evaluation process.

- To integrate different types of and approaches to project evaluation within a practical model. 
- To incorporate sensitivity analysis.

- To produce a supporting tool (excel-based) capable of aiding users in modeling various variables.

\subsection{RESEARCH APPROACH}

In order to develop a model suitable for choosing public investment projects a detailed analysis of both the theory and common practice of decisionmaking has been carried out. Chapters 2 and 3, respectively, cover the theory on the subjects of project evaluation and decision making. In chapter 4 , an insight into the practice of decision-making and project selection in Thailand, as well as the requirements for improving the process, are described.

\subsection{Analysis of the problems and initial responses}

After an initial analysis of the problem (see section 4.I), the realisation arose that public investment projects in many cases fail to perform satisfactorily in general terms, despite the good results obtained in the feasibility analysis. Further investigation (see section 4.2) indicated that the reason for such underperformance was perhaps due to the type of approach used during the evaluation stage. The problem analysis and the investigation also included a review of the most commonly used project appraisal methods.

Most texts concentrate on the economic appraisal of projects, ignoring any other types of effects projects might have. However, despite not being comprehensive enough to cover all the different aspects, these methods produce good outcomes with regard to the economic performance and effects of projects and, therefore, must not be discarded from the investigation.

The literature review carried out showed a lack of interaction and integration between methods from different disciplines. This lack comes to a fore when important issues are left out of the evaluation process because they are not considered relevant. That is to say, different issues have different importance to experts in different areas. This represents a problem, since projects such be evaluated with respect to each category upon completion.

\subsubsection{Development of the methodology}

Once the fundamental part of the problem has been defined, the first actions can be taken towards its solution. It is evident from the analysis that there is a need for integral methods for the evaluation and selection of investment 
projects. The resulting solution must be able to use procedures from different disciplines but at the same time they must be amalgamated to operate as one unit.

In this thesis, the IDM, which is part of the entire public investment decision process, has been divided into five steps that cover all the stages involved in any decision-making process. They are, however, structured in such a way that the final methodology can be built upon these fundamental decision-making activities. The process is structured as follow:

I) Identification of the problem or the chance of improvement. Real life is never static and government agencies are therefore always faced with situations that require a solution or improvement by means of new development and projects. Usually, the strategies of the government and missions of agencies are used as the baseline for improvement, but it is the responsibility of managers and policy-makers to identify the situations at the right time and define their boundaries based on these strategies and their mission so that a solution can be sought.

2) Information gathering. At this stage, a diagnosis of the situation is required to delimit the problem and to proceed with further analysis. The government should compile information from both internal and external sources to identify the effects of the current situation on the economy, the environment and the different areas of society.

3) Development of alternatives. Once the problem has been outlined, managers or decision-makers have to generate a series of alternatives to solve the problem or to improve the situation. This phase acts as a generator of alternatives much like a brainstorming session. At this point, it is important not to discard any alternatives. On the contrary, the main objective is to create more alternatives following an orderly process. During the search for alternatives, however, the decision-maker seldom leaves the evaluation of alternatives until the end of this activity. Instead, he/she immediately rejects those options with extreme values or irrelevant attributes.

4) Evaluation and comparison of alternatives. When enough information is available and sufficient alternatives have been found, the next step is to evaluate them individually and compare the outcomes of each one against the others. The outcomes of every alternative will attain the objectives 
in different degrees and at different costs. Therefore, the decision-maker should consider making an estimate of the effectiveness of each alternative.

5) Choosing among courses of action. This is the high point of the decisionmaking process, although it is incorrectly regarded by many people as the entire process itself. Making a decision means devoting the resources of the organisation to a project that will emerge from the planning board into the physical world. Despite the importance of all the consequences of this phase, choosing is still only a part of the process that would not be possible without the preceding steps.

Additionally, some authors consider that the implementation of actions, their monitoring or follow-up and the implementation of corrective actions complete the cycle. The methodology of IDM developed for this research is structured based upon the fundamental decision-making process described above and is described in a following section later in this chapter.

\subsubsection{Appraisal and testing of the methodology}

This research project could not follow the lines of traditional appraisal and testing because of the long time needed to test the effectiveness of the methodology by applying it to real projects to demonstrate the end outcome. Hence, two alternative testing procedures are used for this task. One of them involved asking experts in different related disciplines to evaluate the model and provide their feedback. This is an appraising test that has been recognised by several authors as an indirect testing technique. The second part of the testing consists of using a sensitivity analysis. Both testing procedures are thoroughly described in Chapter 7.

\subsection{PROPOSED CONCEPTUAL METHODOLOGY}

The underlying principle of the proposed integrated decision model for public investment project evaluation and selection (IDM) is the fact that making decisions does not just involve a single set of criteria determined by economic measures and policies. Therefore, the IDM does not just include an economic model as one of its components, but also focuses on evaluating the impact of investment projects on communities and the environment. Besides economic, social and environmental attributes, the model suggests enhancing long-term implementation of public investment projects by including and measuring 
project support from the local community and stakeholders, which is an important attribute in the evaluation and decision-making process.

Through the application of a number of techniques, the proposed IDM aims to capture the importance of economic and non-economic evaluation factors. This is done by integrating various approaches of project evaluation and decisionmaking within a single model. The results of the evaluation produces a set of comparative scores of alternatives with respect to their performances on economic, social, environmental and long-term project support attribute. Furthermore, the methodology is designed to be flexible in a way that allows the users of the methodology to add additional attributes or to replace various original models with new relative ease one. The IDM methodology of project evaluation and selection is shown in Figure 5.I.

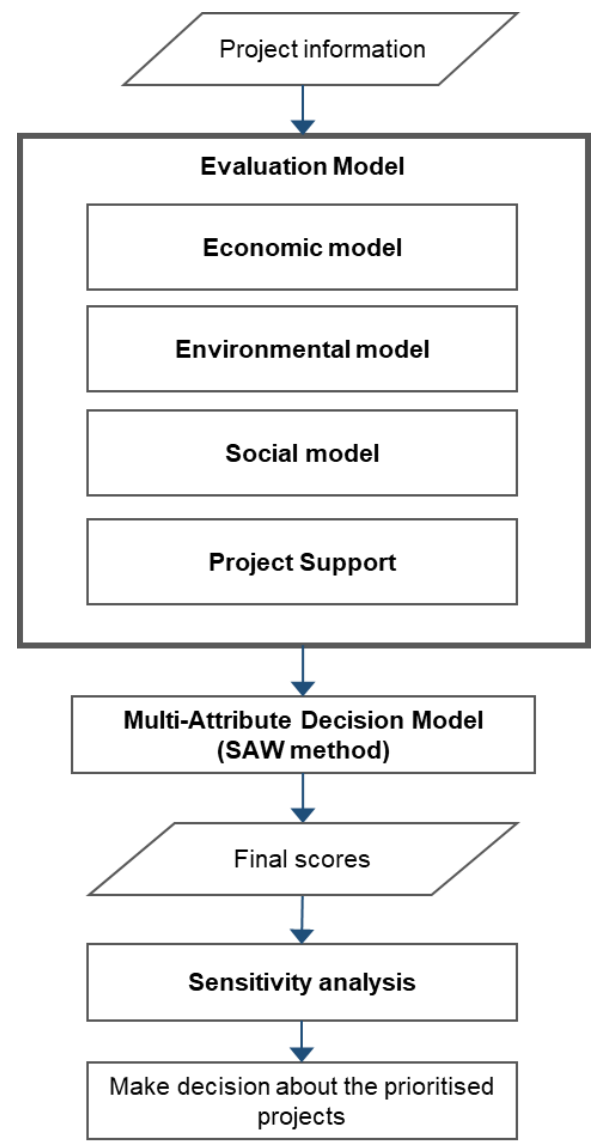

Figure 5.I The methodology of an integrated decision model for public investment project evaluation and selection (IDM) 
As indicated in Figure 5.I, after the initial stage of setting objectives, the project organisations and decision makers will need to generate a series of alternatives to solve the investment problem or to improve the existing situation. Once all these steps are finalised, the full project evaluation and selection stage can be performed using the IDM methodology. The methodology consists of two fundamental elements, the evaluation part and the selection part.

The following sections present the development of the IDM based on this conceptual solution, which is divided into two parts; the project evaluation part (in section 5.4) and the selection part, as a decision-making model (in section 5.5).

\subsection{ELEMENTS OF PROJECT EVALUATION}

This section describes the models used by the methodology to evaluate projects from economic, social, environmental and project support viewpoints as described in the following sections.

\subsection{Economic Evaluation}

Based on the criteria selected in section 4.3.3, the economic aspect is measured using economic viability. The general purpose of the economic model is to measure the added economic value of a project by comparing its costs and benefits. This section presents a comparison between the two most commonly used Discounted Cash Flow (DCF) techniques for this purpose. This comparison was considered necessary given the similarities between NPV and IRR to justify the selection of one of them for the final economic evaluation.

Both methods have their followers and the literature shows that neither of them is used predominantly. Over the years however, the trend seems to be shifting towards the NPV technique within organisations. Equation (5.I) and (5.2) show the calculations of NPV and IRR respectively.

$$
\begin{aligned}
N P V & =\sum_{t=0}^{n} \frac{C_{t}}{(1+i)^{t}} \\
0 & =\sum_{t=0}^{n} \frac{C_{t}}{(1+I R R)^{t}}
\end{aligned}
$$


where $C_{t}$ is the project's cash flow (either positive or negative) in time $t$ and $i$ is a discount rate.

One of the major problems with IRR occurs whenever there is more than one change in the sign of the cash flows. If the project is not conventional, so that cash flows have more than one change in sign, the number of real solutions can vary from 0 to $m$, where $m$ is the number of sign changes in the cash flow. To add some more confusion to the situation, there are cases in which no IRR exists.

The advantages of the NPV over IRR are not all of a conceptual nature, but are also operational in some cases. In order to find the IRR of projects with cash flows extending over more than three points in time, one must find solutions to complex polynomial equations.

In summary, the advantages of NPV over IRR can be found in Osborne (20I0), Mahmoodzadeh, et al., (2007) for example, and are summarised in the following list:

\section{Theoretical justification of the NPV rule}

- Maximises investor utility

- Takes into account investment size

- Reinvests cash flows at the relevant rate

\section{Technical disadvantages of the IRR criterion}

- Non-conventional cash flows where cost of capital very over time cause imaginary or multiple values of IRR

- Ignores the size of initial investment cost

According to the NPV, the analysis for the evaluation is that the higher NPV represents the better economic alternative.

In some cases where benefits and costs cannot be easily measured, changing the approach from CBA to CEA (cost-effectiveness approach) is suggested, see for example: Shaner (1979). The CEA approach can deal with qualitative returns and only requires information related to cost of a certain course of action. The analysis of CEA is presented in a ratio of incremental cost to incremental effect. 


\subsubsection{Social Evaluation}

Traditionally, both Cost-Benefit Analysis and Cost Effectiveness Analysis (CBA and (CEA), as perceived by public-sector economists, are techniques that try to take into account factors disregarded by the private sector (Mishan \& Quah, 2007). Public-sector investment decisions recognize that applying economic methods in social assessment has difficulties relating to determining an appropriate social discount rate (Brzozowska, 2007; Scarborough, 20I I).

A fundamental part of this social model is to treat and evaluate costs and benefits in units other than money. To overcome this difficulty, a new model is developed so that benefits and costs are still amalgamated into a single measure for comparison purposes. This uniform measure however, does not rely exclusively on monetary factors. This model is developed to respond to different needs of local community affected by a project which is not addressed by the current system of public investment project evaluation. It is designed to model the interaction between a project and local communities in the project area. To do so, the model includes the four main social factors selected by the experts. These are:

(I) Distributional effects

(2) Area-based requirement/priority

(3) The local employment and economic impacts on the population

(4) The impacts on the quality of life (i.e. services, health, education) of the population affected.

The first social factor reflects the position of the affected groups within the national economic spectrum and the extent to which the impact is distributed among these distinguished groups (Cadena \& Magro, 2015). The second factor signifies the priority given to the areas of the project based on the needs of people in those areas (Cowell \& Gardiner, 2000; Aksorn \& Charoenngam, 2015). According to the definitions of these two factors, the intention of this model is that the groups that have the greatest need for improvements are given higher weights during the evaluation. For this reason, these two factors can be called 'social variables'.

The third and fourth factors selected by experts reflect the two main social impact components that are affected whenever a set of actions is implemented. These components respectively represent the economic (e.g. local income, employment) and the non-economic ( $Q \circ L$ and well-being) impacts of the project. In general, the overall QoL and well-being are made up by various 
intangible factors, such as quality of goods and services, access to goods and services and safety, and are given by many social studies, such as Bauer (1966); Casas (20II); Folds \& Thompson (20I3). In this model, it is considered that in order to maintain the simplicity of the model, it would be better to group them into a single factor called "quality of life (QoL)"

The different groups in a project area are identified based on the concept of optimal distribution, which involves the prioritisation given to various individual groups by using their different income levels (Cowell \& Gardiner, 2000; Adler, 2016). Therefore, the model proposes the classification of the population affected by the project into groups based on their income level. Table 5.I presents a proposed classification of population groups and the value of priority weights according to the classification.

The underlying principle is that a population group that can be considered to be disadvantaged (very poor people) or has urgent needs for development can be given a higher priority weight than others. This means that higher percentages are given to disadvantaged groups to improve their situation and to reduce the discrepancies between them and other better off groups.

Table 5.I Income level of the affected groups

\begin{tabular}{|c|l|c|}
\hline $\begin{array}{c}\text { Population } \\
\text { group }\end{array}$ & \multicolumn{1}{|c|}{ Income level } & $\begin{array}{c}\text { Priority weights } \\
\text { (\%) }\end{array}$ \\
\hline A & Very low income/very poor & 100 \\
\hline B & Low income/poor & 80 \\
\hline C & Medium income & 60 \\
\hline D & High income/rich & 20 \\
\hline E & Very high income/very rich & 5 \\
\hline
\end{tabular}

The common way of assessing social impact is evaluated for the whole population regardless of the number of groups in it. For this reason, it is necessary to represent every group as a component of the population rather than as a whole population in itself. Hence the total population is defined as $100 \%$ and the proportion of the population made up by each group $(P)$ will be stated as a percentage of the total population.

Measuring the social impacts in this model concerns the positive and negative impacts of the latter two social factors; the impact on local economy (EI) and 
QoL, where the investment is made. The model uses a qualitative 5-point scale to assign the degree of impact of each alternative as shown in Table 5.2. The score of 5 indicates the highest positive social improvement and 0 represents a negative social impact. Using the proposed scale will help transforming descriptive social impacts measurements (very high, low or insignificant impacts etc.) into numerical values.

Table 5.2 Economic impacts on the affected groups (El)

\begin{tabular}{|l|l|c|}
\hline \multicolumn{1}{|c|}{ Economic impact (EI) } & Repercussions on QoL & Score \\
\hline Significant increase on PCl & Significant improvement & 5 \\
\hline Medium increase on PCl & Medium improvement & 4 \\
\hline Low increase on PCl & Low improvement & 3 \\
\hline Low decrease on PCl & Low depletion & 2 \\
\hline Medium decrease on PCl & Medium depletion & I \\
\hline $\begin{array}{l}\text { High decrease on PCl } \\
\text { income }\end{array}$ & Significant depletion & 0 \\
\hline
\end{tabular}

Once the groups are identified and given a weight according to Table 2, the social impacts (El and QoL) are determined according to Table 3 for every group in an independent way. This study proposes the use of the social evaluation formulae (5.3) and (5.4) to combine the social impacts and variables into a final social score of alternative $i$ as follows:

$$
\begin{gathered}
S C_{i}=\sum_{n=1}^{k} G_{i n} \\
G_{i n}=\left[E I_{i n}+Q o L_{i n}\right] \cdot w_{n} \cdot P_{i n}
\end{gathered}
$$

where:

$G_{i n}$ is the social score of population group $n$ of alternative $i$

$E I_{\text {in }}$ is the local economic income score on population group $n$ of alternative $i$

$Q o L_{i n}$ is the quality of life impact score on population group $n$ of alternative $i$

$w_{n}$ is the priority weight of population group $n$

$P_{\text {in }}$ is the proportion of population group $n$ of alternative $i$ 
The final social score for an alternative $\left(S C_{i}\right)$ is obtained by adding the social scores $\left(G_{i n}\right)$ of all population groups affected by the project.

\section{Illustrative example}

Suppose a project is set to have effects on three different groups classified according to their income level and proportion of the whole population as follows:

Group A. Very low income (50\% of the affected population)

Group B. Low income (35\% of the affected population)

Group C. High income (15\% of the affected population)

The project has two effects that modify the existing conditions of the three groups in different ways. These effects are presented in Table 5.3, referring to the classification made in Tables 5.2 .

Table 5.3 Effects of the project on the identified groups

\begin{tabular}{|l|l|l|l|l|}
\hline \multirow{2}{*}{ EFFECT } & \multicolumn{1}{|c|}{ Category } & \multicolumn{1}{|c|}{ Group A } & \multicolumn{1}{|c|}{ Group B } & Group C \\
\cline { 2 - 5 } & $\begin{array}{l}\text { Economic } \\
\text { impact (EI) }\end{array}$ & $\begin{array}{l}\text { Significant } \\
\text { improvement }\end{array}$ & $\begin{array}{l}\text { Medium } \\
\text { improvement }\end{array}$ & Null effect \\
\cline { 2 - 5 } & $\begin{array}{l}\text { Quality of life } \\
\text { (QoL) }\end{array}$ & $\begin{array}{l}\text { Medium } \\
\text { improvement }\end{array}$ & $\begin{array}{l}\text { Medium } \\
\text { improvement }\end{array}$ & Null effect \\
\hline
\end{tabular}

To obtain the social score for each group using formula (5.4), the associated values taken from Tables 5.2 are used with the effects in Table 5.3 and are added together and multiplied by the priority weight from table 5.I. The result is multiplied by the proportion of the population in the following way:

Score $($ group $A)=[$ Significant improvement $(5)+$ Medium improvement $(4)] x$ $\mathrm{I} \times 0.5=4.5$

The same calculations are carried out for each group obtaining the following results:

Group $A=4.5$

Group B $=2.24$ and

Group C = -

Social score of the project $(\mathrm{SC})$ followed formula $(5.3)=4.5+2.24=6.74$ 


\subsubsection{Environmental Impact Evaluation}

The selected criterion for the environmental aspect is the impact/disturbance on natural resources. Typically, environmental impact issues are broad and difficult to define. Most assessment frameworks, such as EIA, tend to be comprehensive with respect to incorporating environmental issues and also include other factors, such as financial and social aspects and public participation. Attempting to be comprehensive in one assessment by including many issues and aspects leads to the assembly and analysis of complex information. Consequently, it means this information is difficult to use when making a decision. Striking a balance between completeness and simplicity of use is one of the challenges in developing an effective and efficient environmental assessment tool (Ding, 2008).

The purpose of the environmental model used in this work is to develop an easy and reliable way to compare the overall environmental impact of various alternatives. A single environmental attribute is suggested here to combine the overall impact of each project on natural resources and the environment during the construction and implementation of a project. Similar to the scale used in the social model, this model also applies a qualitative 5-point scale, which is used to indicate the degree of environmental impact that can be either positive or negative. The highest score of 5 represents the highest improving condition on the environment influenced by the project. On the other hand, score of 0 means that the project has very high negative impact on the environment. This approach allows for the combination of various environmental impact issues, regardless of the types of project or the number of issues in question, into a single index of evaluation. The proposed qualitative 5-point scale and description are shown in Table 5.4. The example of how to use the qualitative rating scale to deal with various environmental issues is illustrated in Table 5.5. 
Table 5.4 Qualitative rating scale to indicate an environmental impact degree

\begin{tabular}{|c|c|c|}
\hline \multicolumn{3}{|c|}{ Environmental impact } \\
\hline \multirow{3}{*}{$\begin{array}{l}\stackrel{0}{\geq} \\
: \frac{1}{n} \\
0 \\
0\end{array}$} & High improvement & 5 \\
\hline & Medium improvement & 4 \\
\hline & Low improvement & 3 \\
\hline \multirow{3}{*}{$\begin{array}{l}\stackrel{0}{2} \\
\stackrel{2}{0} \\
\underset{0}{0} \\
\mathbf{Z}\end{array}$} & Low degradation & 2 \\
\hline & Medium degradation & $\mathrm{I}$ \\
\hline & High degradation & 0 \\
\hline
\end{tabular}

Table 5.5 Example of qualitative rating scale used for evaluation

\begin{tabular}{|l|l|c|l|c|}
\hline \multirow{2}{*}{$\begin{array}{c}\text { Environmental } \\
\text { impact issues }\end{array}$} & \multicolumn{2}{|c|}{ Alternative A } & \multicolumn{2}{c|}{ Alternative B } \\
\cline { 2 - 5 } & Impact & Score & \multicolumn{1}{c|}{ Impact } & Score \\
\hline Water quality & Medium improvement & 4 & Medium improvement & 4 \\
\hline Air quality & Low degradation & 2 & Low degradation & 2 \\
\hline Land use & High improvement & 5 & Medium improvement & 4 \\
\hline Habitat and fauna & Medium degradation & $\mathbf{I}$ & High degradation & 0 \\
\hline \multicolumn{1}{|c|}{ Total score } & & $\underline{\mathbf{I 2}}$ & & $\underline{\mathbf{1 0}}$ \\
\hline
\end{tabular}

\subsubsection{Project support}

The project support aspect, community cooperation and collaboration, is included in an attempt to secure the involvement of the public and local communities. It was selected as an important criterion by the experts, because it can help ensure that the project will be supported by these communities and will have a long-term success. Literature analysis and practice show that although the benefits of public and local community participation are known, the role and capacity of stakeholders and local communities involving development activities and influencing decisions remain unknown (Bawole, 20I3; Nadeem and Fischer, 20II). 
Table 5.6 Qualitative rating scale for project support

\begin{tabular}{|c|c|c|c|c|}
\hline $\begin{array}{l}\text { Level of } \\
\text { support }\end{array}$ & Degree & $\begin{array}{l}\text { Description } \\
\text { /Outcome }\end{array}$ & $\begin{array}{c}\text { Participation } \\
\text { method }\end{array}$ & $\begin{array}{l}\text { Choguill's } \\
\text { ladder }\end{array}$ \\
\hline Strong & 3 & $\begin{array}{l}\text { Active communication } \\
\text { between government and } \\
\text { local community and (if } \\
\text { needed) other stakeholders } \\
\text { to realise a project. The } \\
\text { community and stakeholders } \\
\text { have rights to initiate } \\
\text { activities or make alliances } \\
\text { by themselves or with the } \\
\text { support of external agencies. } \\
\text { In this case, a degree of } \\
\text { freedom to do so depends } \\
\text { on the level of governmental } \\
\text { willingness or confidence in } \\
\text { the community's ability to } \\
\text { contribute such project. }\end{array}$ & $\begin{array}{l}\text { - Community } \\
\text { association with or } \\
\text { without government } \\
\text { assistance in a project } \\
\text { - Joint planning } \\
\text { committees with local } \\
\text { community members } \\
\text { - Representatives of } \\
\text { the community in } \\
\text { advisory groups or } \\
\text { decision-making bodies } \\
\text { to reflect their } \\
\text { cooperation. }\end{array}$ & $\begin{array}{l}\text { Empowerment } \\
\text { Partnership } \\
\text { Conciliation }\end{array}$ \\
\hline Fair & 2 & $\begin{array}{l}\text { A formal participation and } \\
\text { involvement which is } \\
\text { controlled by government } \\
\text { offices. Local communities } \\
\text { and stakeholders are invited } \\
\text { to be involved in a project in } \\
\text { order to achieve a } \\
\text { semblance of community } \\
\text { participation. In this case, } \\
\text { the government, with or } \\
\text { without external } \\
\text { consultants, educates them } \\
\text { regarding the situation and } \\
\text { the necessity of the project. } \\
\text { A democratic mechanism is } \\
\text { used for this purpose. }\end{array}$ & $\begin{array}{l}\text { - Few representatives } \\
\text { of the community in } \\
\text { advisory committees } \\
\text { with a governmental } \\
\text { control } \\
\text { - Attitude surveys, } \\
\text { public hearings } \\
\text { - Meetings with } \\
\text { residents and visiting } \\
\text { the neighborhood }\end{array}$ & $\begin{array}{l}\text { Dissimulation } \\
\text { Diplomacy }\end{array}$ \\
\hline Weak & $T$ & $\begin{array}{l}\text { One-way flow of } \\
\text { information from } \\
\text { government officials to the } \\
\text { community and } \\
\text { stakeholders. Feedback and } \\
\text { negotiation are not in place. } \\
\text { This is a top-down initiative. }\end{array}$ & $\begin{array}{l}\text { - Informing basic } \\
\text { information of a project } \\
\text { such as a proposal, } \\
\text { advertisements, } \\
\text { announcement }\end{array}$ & Informing \\
\hline None & 0 & $\begin{array}{l}\text { No stakeholder participation } \\
\text { in the formal decision- } \\
\text { making process is allowed. } \\
\text { This includes cases where } \\
\text { the authorities only give the } \\
\text { reasons for wanting to solve } \\
\text { the problem and actually } \\
\text { control the project. }\end{array}$ & None & $\begin{array}{l}\text { Conspiracy } \\
\text { Self-management }\end{array}$ \\
\hline
\end{tabular}

Based on the analysis of literature discussed in chapter 2, there are many ways of achieving public participation and each of them provides different outcomes 
which produce various levels of stakeholders support for a project. However, in practice, most public decisions include public participation as a checklist requirement, without considering the outcome and levels of commitment among key stakeholders and public project organisers. It is applied only to ensure that a project meets a national regulation of public investment in order to be approved for funding, but it cannot guarantee the long-term success of a project that could be derived from mutual support by local communities.

In this model, the participation and engagement of a project supported by stakeholders and local communities is measured and included into the evaluation. The model uses a qualitative rating scale representing the degrees of support by various stakeholders. The rating scale is adapted from the eightrung ladder of community participation developed by Choguill (1996), as his approach can be adequately applied in developing countries. A high score in the scale presents a strong level of public involvement and local commitment incorporated in the project. The scale levels are assigned values between 3 and $0 ; 3$ being strong support, 2 is medium, I is weak and 0 representing no support. The descriptions of each level are explained in Table 5.6, which also includes various participation methods used to provide outcomes in each level as a guideline to identify a project's degree of support. The strong level represents a high degree of public involvement in and local commitment to the project.

The following step in the methodology is a decision-making model (the selection part) that combines the scores on all attributes (economic, environmental, social, and project support) to determine the final evaluation score of each alternative.

\subsection{DECISION-MAKING MODELS}

This section illustrates the decision model used in the methodology for project selection without specifying all the intermediate steps necessary in the complete process. It also includes an example, without reference to any particular field of application, to clarify the process.

Most problems that prompt decisions in real life will require decision-makers to establish multiple attributes/criteria to evaluate whether the objectives have been achieved. Therefore, the main assumption of this model is a situation in which a problem involves the use of multiple criteria for its solution. In order to determine the performance of alternatives in the attainment of the 
objectives, a number of criteria must be defined, and the criteria performances must be aggregated to reach a single score.

There are many methods in the approach of Multi-Attribute/Criteria DecisionMaking (MADM/MADM) and some of them have been widely used in practice. For example, Saaty (1990) and Dey (2006) have suggested the use of Analytical Hierarchy Process (AHP) or optimisation models to help solving complex problems by synthesising diverse intuitive considerations of stakeholders into results (Widianta et al., 2018). AHP is often used to assist group decision makers to compare and select between projects (Huang et al., 2008). Joshi and Sharma (2016) and Lateef-Ur-Rehman (2013) have applied Preference Ranking Organization Method for Enrichment Evaluation (PROMOTHEE) to rank various alternatives of a decision. This represents a synthesising preference relational system which does not work on alternatives in isolation but compares alternatives with each other. It requires inputs from decision-makers into preference function to rank alternatives. Among other methods, Memariani et al. (2009) and Afshari et al. (2010) have suggested the use of Simple Additive Weighting (SAW) which is known as a weighted scores method to evaluate alternative performances based on relative importance weights. SAW is one of the classical MCDM/MADM methods which is simple and is the basis of most MADM techniques such as AHP and PROMOTHEE (Wang, 20I5; Memariani et al., 2009). The underlying assumption of the SAW method is that attributes are preferentially independent. This means that the contribution of an individual attribute to the total final score is independent of other attribute values (Yoon and Hwang, 1995). In other words, the SAW method is a true-criterion model which does not require any preference function determined by decision-makers and stakeholders and thus SAW requires less work for decision makers along the entire decision-making process.

The selection part in the IDM uses the SAW model in the MADA approach. SAW is used to rank a set of alternatives to help decision makers selecting the relative best available one (Kabassi and Virvou, 2004). It is used because it requires less involvement of decision makers and a score of each attribute is independently contributed into the total final score which is consistent with the concept of the IDM. The four distinct evaluation results based on economic, social, environmental, and project support models can then be combined into a single evaluation score. 
The steps used in the SAW model are proposed by Yoon and Hwang (1995); Wang (20I5); and Adriyendi (20I5), are adapted for the IDM and are described as follows:

Let $A=\left(a_{1}, a_{2}, \ldots, a_{i}, \ldots, a_{m}\right)$ be a set of alternatives

Let $C=\left(c_{1}, c_{2}, \ldots, c_{j}, \ldots, c_{n}\right)$ be a set of attributes

I) After obtaining all the performance values for each alternative, they are put in a decision matrix $(m \times n)$ such as the one illustrated in Table 5.7.

Table 5.7 Decision-making matrix of alternatives

$\begin{array}{cccccc} & \boldsymbol{C}_{\mathbf{1}} & \boldsymbol{C}_{\mathbf{2}} & \ldots & \ldots & \boldsymbol{C}_{\boldsymbol{n}} \\ \boldsymbol{A}_{\mathbf{1}} & d_{11} & d_{12} & \ldots & \ldots & d_{1 n} \\ \boldsymbol{A}_{\mathbf{2}} & d_{21} & d_{22} & \ldots & \ldots & d_{2 n} \\ \vdots & \vdots & \vdots & \ldots & \ldots & \vdots \\ \vdots & \vdots & \vdots & \ldots & \ldots & \vdots \\ \boldsymbol{A}_{\boldsymbol{m}} & d_{m 1} & d_{m 2} & \ldots & \ldots & d_{m n}\end{array}$

where $d_{i j}$ is the attribute value of alternative $i$ with respect to attribute $j$.

2) Normalise decision matrix by calculating the value of alternative $i$ with respect to attribute $j$ when compared to other alternatives on the same attribute. The normalisation method used in this model involves dividing the performance ratings of each attribute by the maximum performance rating for that attribute (Chakraborty \& Yeh, 2009).

For benefit attributes, the normalised value $r_{i j}$ is obtained with

$$
r_{i j}=\frac{d_{i j}}{d_{j}^{\max }}
$$

For cost attributes, $r_{i j}$ is obtained with

$$
r_{i j}=\frac{d_{j}^{\min }}{d_{i j}}
$$


where:

$d_{j}^{\max }$ is the maximum performance value among alternatives for attribute $C_{j}$

$d_{j}^{\text {min }}$ is the minimum performance value among alternatives for attribute $C_{j}$

and $d_{i j}>0$

For the purpose of simplicity, the results are multiplied with 100 to yield a result expressed as a percentage, making the results easier to understand for non-technical decision analysts.

3) Assign a weight of importance between 0 and $I$ to each of the attributes. The sum of all weights must be $I$.

4) Calculate a weighted evaluation score for each alternative $A_{i}$ by applying the following formula:

$$
S_{i}=\sum_{j=1}^{n} w_{j} . r_{i j}
$$

where:

$S_{i}$ is the final weighted score of alternative $i$

$w_{j}$ is the weight given to attribute $j$

$r_{i j}$ is the normalised score achieved by the alternative $i$ on attribute $j$

5) Rank the alternatives from the highest to lowest scores for selection

\section{Illustrative example}

Suppose the problem of choosing an alternative among a set of alternatives based on 4 attributes $C_{1}$ (economic), $C_{2}$ (social), $C_{3}$ (environmental), and $C_{4}$ (project support), which are all expressed in different units. After defining and evaluating the alternatives, the individual has three options to choose from, which are defined as follows:

$A_{1}=(2000,7,25,150)$ 
$A_{2}=(7000,3,10,70)$

$A_{3}=(3500,8,15,200)$

For the first row in the matrix, the normalisation results of the division are calculated as follows:

$d_{11}=(2000 / 7000) \times 100=28.5$

$d_{21}=(7000 / 7000) \times 100=100$

$d_{31}=(3500 / 7000) \times 100=50$

The same calculation is performed for the rest of the elements in the matrix, giving the following new values:

\begin{tabular}{|c|c|c|c|c|}
\hline & $C_{1}$ & $C_{2}$ & $C_{3}$ & $C_{4}$ \\
\hline$A_{1}$ & 28.5 & 87.5 & 100 & 75 \\
\hline$A_{2}$ & 100 & 37.5 & 40 & 35 \\
\hline$A_{3}$ & 50 & 100 & 40 & 100 \\
\hline
\end{tabular}

The decision-maker determines that the importance weight of each attribute is assigned as follows:

$w_{1}=0.20$

$w_{2}=0.30$

$w_{3}=0.10$

$w_{4}=0.40$

To incorporate the weights into the calculation, the decision-maker multiplies each score by the weight given to the particular attribute. The final result, then, is the following:

\begin{tabular}{|c|c|c|c|c|c|}
\hline & $C_{1}$ & $C_{2}$ & $C_{3}$ & $C_{4}$ & Final weighted score \\
\hline$A_{1}$ & 5.7 & 26.25 & 10 & 30 & $\mathbf{7 1 . 9 5}$ \\
\hline$A_{2}$ & 20 & 11.25 & 4 & 14 & $\mathbf{4 9 . 2 5}$ \\
\hline$A_{3}$ & 10 & 30 & 6 & 40 & $\mathbf{8 6}$ \\
\hline
\end{tabular}

Finally, all the scores are added up for each alternative, thus obtaining their final weighted scores:

$A_{1}=71.95, \quad A_{2}=49.25, \quad A_{3}=86$ 
In this example, the alternative with the highest score on the most important attribute also turned out to be the alternative with the highest overall score. The outcome is not accidental, but one must not be misguided and think that all they need to do is determine the most important attribute and evaluate each alternative on said attribute. In real-world problems, the final outcome depends very much on the criteria used to perform the appraisals and the number of attributes involved in the process.

\subsection{STRUCTURE OF THE METHODOLOGY}

In this thesis, special emphasis is put on the fact that making decisions is not just a matter of a single set of criteria determined by economic measures and policies. With this in mind, the developed IDM includes an economic model and its set of criteria as one of the components of the process, rather as the base upon which the whole decision process rests. In addition, the researcher considers that social benefits are one of the main concerns of public organisations when undertaking new investment projects.

For that reason, the methodology of the IDM includes criteria that should be taken into account when analysing the effects of projects on the population and their well-being. After analysing the different methods for project evaluation in public sectors, separate procedures have been developed to appraise projects from economic, environmental, social and project support points of view. The following sections, prior stages and the steps of the methodology for project evaluation and selection developed during this study are described and illustrated in Figure 5.2.

I. Specify the overall objective and the main sub-objectives that will contribute to the overall objective. A preliminary list can be produced and ranked in terms of importance. The formulation of the organisation's objectives has been intentionally left out of the methodology, because although they determine the guidelines for the whole process, they are not exclusive to the project selection task.

2. Determine a set of relevant decision attributes to be evaluated as well as the measurement criteria and units for these attributes. Most projects considered by the decision-makers will be similar to a certain extent. For this reason, establishing attributes common to all of them and relevant enough to describe them thoroughly is a very important task. This step also includes defining cut-offs and constraints (i.e. 
minimum or maximum acceptable values for a given attribute) to be used as pre-screening criteria to reduce the total number of alternatives.

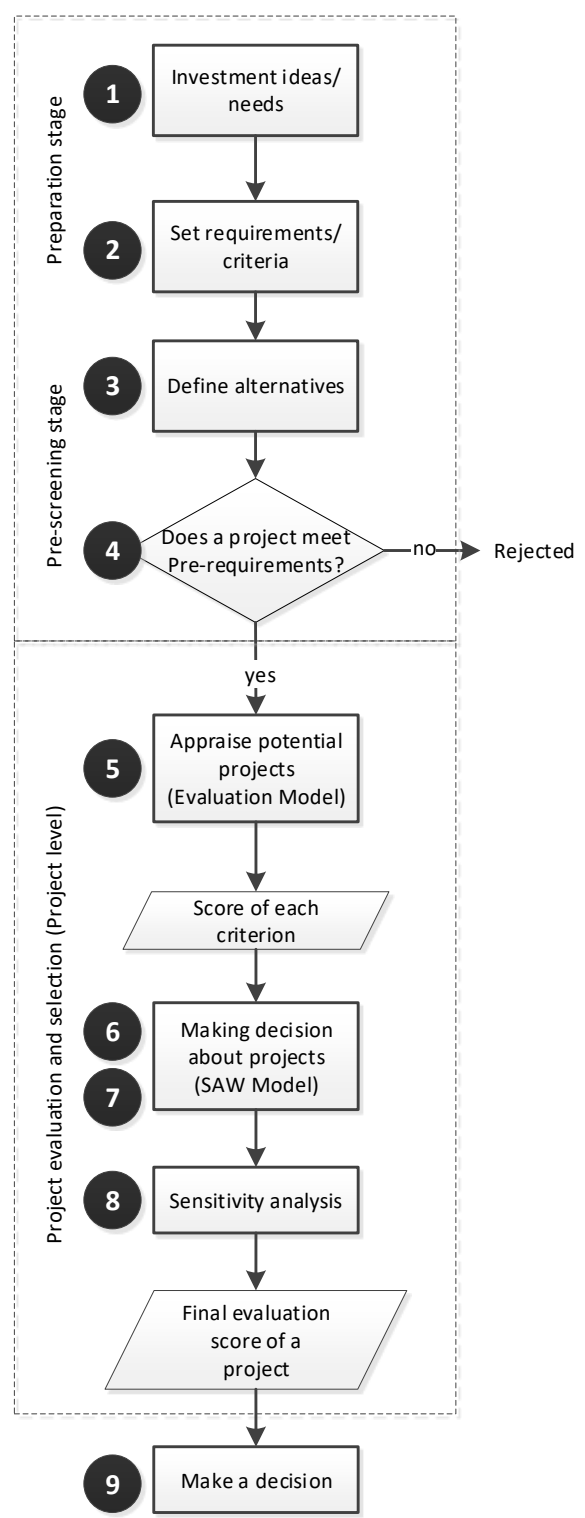

Figure 5.2 The IDM methodology and relevant steps within the process

3. Define alternatives (i.e. physical and technical characteristics of each project). 
a. Identification of sources of funding. This is done in order to check the consistency of the cash flows at a later phase, according to the financing plan.

b. Identification of the beneficiary groups with special attention to primary recipients of the benefits deriving from the project.

c. Compilation of socio-economic information about the main beneficiary groups to determine their position within the surrounding economic environment.

d. Determine the non-monetary effects, both positive and negative and estimate their values when possible.

4. Compare alternatives with the prerequisites set by the government. If a particular alternative fails to satisfy one or more (this depends on the decision-maker) of the cut-off criteria, the alternative is eliminated.

5. Evaluate impact of the remaining alternatives with regard to the set of evaluation criteria (economic, social, environmental and project support aspects) in the evaluation model.

6. Order the evaluation results of each alternative in a MADM decision matrix and establish the attribute hierarchy by assigning importance weights. In fact, the attribute weights can be defined by decision-makers at any stage of the methodology before calculating a final overall score.

7. Follow the SAW model procedure to obtain the final weighted scores of all alternatives.

8. Carry out the sensitivity analysis.

9. Choose the most robust choice.

The developed methodology described in this chapter intends to represent the entire process of a public investment project decision. The preparation and prescreening stages (no. I - 4) are supposed to be authorised by an executive decision maker(s) to set the investment needs and screen the most potential and relevant alternatives. The screening stage can also include the budgeting system organised by the BB. Subsequently, when the potential alternatives pass the prior stages, the full project evaluation and selection process can be conducted (stages no. 5 -8). These steps will be mainly organised by one or more evaluators (project analysts) or a specialist team performing the analysis. This team occasionally works together with one or more decision-makers in 
assigning the attributes weights. If needed, the decision-maker can also make suggestions along the process. Finally, once the evaluator has obtained evaluation scores of all alternatives, the final selection process, with the goal of choosing the most robust choice, will be carried out by the decision-maker(s) at step no. 9.

\subsection{REQUIRED MODEL INFORMATION}

As seen from the description of the model, quite a large amount of information is required in order to provide an outcome that will ultimately lead to the selection of an investment project. It may be said that most of the information required will already exist by the time the feasibility appraisal of the project takes place, since much of it is of a qualitative nature. Most of the problems can come from the economic and financial information, such as cash flows and repayment conditions of borrowed money.

In general, the information needed to carry out the methodology is the expected to be the following:

I. Type of project

2. General description of the project

3. Potential alternatives of the project

4. Financing of the alternatives

5. Total cost of the alternatives and expected benefits

6. Cash flows (if available)

7. Development time

8. Starting time of operations

9. Number of jobs generated

10. Number of direct beneficiaries

II. Social effects

12. Environmental effects

13. Conditions of project support

14. Attribute weights assigned by a decision-maker 
Not all of this information is fed directly into the model, with some of it being processed first. Such is the case for all the information pertaining to the social and environmental aspects. In those cases, all the qualitative information has to be measured by means of some verbal scale and then be assigned a score such as the one described earlier.

The next chapter demonstrates the application of the proposed decision model and how existing project information can be processed into the model through two public investment project cases from Thailand. 


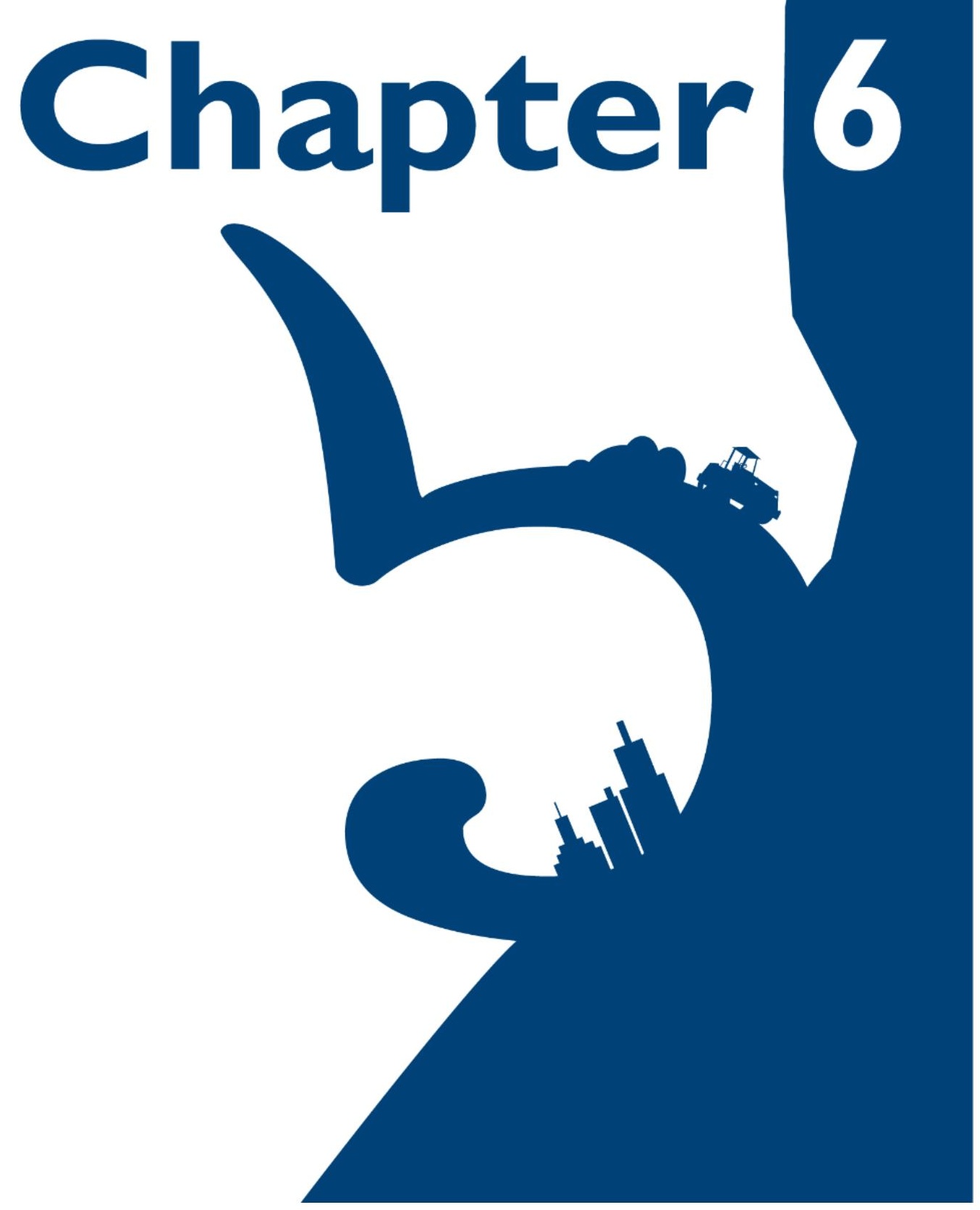




\section{APPLICATIONS OF THE METHODOLOGY AND DECISION MODEL}

In this chapter, the methodology and the decision model are applied to two existing investment projects in Thailand. The two applications are performed in order to validate whether all variables and factors included in the IDM are appropriate. Furthermore, the adaptability and flexibility of the IDM will also be tested. The selection of the existing project cases is based on an attempt to represent different characteristics of projects of different sizes and in different sectors. The first case is related to water resource management and concerns the irrigation system development programme in the Yom River Basin. The second case is a project in the transport sector with the aim to improve local access by means of a road network.

To help demonstrate the model, each case first provides a description of the project in question, including project information, locations, alternatives and existing information used according to the current manner of evaluation. Then, the IDM, as outlined in sections $5.4-5.6$ is applied to each case. The results of applying the IDM are compared with the results from the existing assessment and they will be discussed at the end of each case.

\section{I CASE I: An Irrigation Development Project in Yom River Basin, Thailand}

Project owner: The Royal Irrigation Department (RID), Ministry of Agriculture and Cooperatives

\section{I.I Project description}

The Yom River Basin is located in the north of Thailand and is one of the main tributaries of the Chao Phraya River, the major river of the country. The basin boundary covers II provinces and supports about $9,537 \mathrm{~km}^{2}$ of cultivated area. Annually the Yom River is subjected to flooding and severe drought, which impact people's livelihoods in the area. In an attempt to improve the situation, several water resource management plans were introduced, one of which was initiated by the RID. 
At the early stage of the plan, many alternatives were introduced, and initial feasibility studies were carried out on each of them by project analysts and consultants of the RID. Many options were examined and chosen during the feasibility study in order to reduce the number of alternatives. Mainly, four competing alternatives were chosen for further detailed assessment. The four alternatives are briefly presented in Table 6.I.

Table 6.I Alternatives information of the irrigation project

\begin{tabular}{|c|l|l|c|l|}
\hline Alternative & \multicolumn{1}{|c|}{ Name } & \multicolumn{1}{|c|}{ Location } & \multicolumn{2}{|c|}{ Direct beneficial area } \\
\hline A & $\begin{array}{l}\text { Mae-Kon } \\
\text { Reservoir }\end{array}$ & $\begin{array}{l}\text { Cho Hae Sub- } \\
\text { District, Mueang } \\
\text { Phrae District }\end{array}$ & $\begin{array}{c}13 \\
\mathrm{~km}^{2}\end{array}$ & $\begin{array}{l}\text { Mueang Phrae and } \\
\text { Sung Men } \\
\text { Districts, Phrae } \\
\text { Province }\end{array}$ \\
\hline B & $\begin{array}{l}\text { Mae-Thun-Noi } \\
\text { Reservoir }\end{array}$ & $\begin{array}{l}\text { Klang Dong Sub- } \\
\text { District, Thung } \\
\text { Saliam District }\end{array}$ & $\begin{array}{c}4.6 \\
\mathrm{~km}^{2}\end{array}$ & $\begin{array}{l}\text { Thung Saliam } \\
\text { District, Sukhothai } \\
\text { Province }\end{array}$ \\
\hline C & Mae-Teep & $\begin{array}{l}\text { Chang Nuea Sub- } \\
\text { District, Mae Mo } \\
\text { District }\end{array}$ & $\begin{array}{l}23.2 \\
\mathrm{~km}^{2}\end{array}$ & $\begin{array}{l}\text { Mae Mo and Ngao } \\
\text { Districts, Lampang } \\
\text { Province }\end{array}$ \\
\hline Deservoir & Pong-Phak & $\begin{array}{l}\text { Wiang Mok Sub- } \\
\text { District, Thoen } \\
\text { District }\end{array}$ & $\begin{array}{l}\mathrm{Il.2} \\
\mathrm{km}^{2}\end{array}$ & $\begin{array}{l}\text { Thoen District, } \\
\text { Lampang Province }\end{array}$ \\
\hline
\end{tabular}

According to relevant regulations for major-scale projects (size of more than $128 \mathrm{~km} 2$ irrigation area), an environmental impact assessment (EIA) report has to be made. In this case, even though the project is not considered as a major project because its size is less than the specified limit, still it was considered that the project impacts could influence considerable amounts of household and land in the area. For this reason, it was decided to perform an initial environmental examination (IEE) report, which is a brief statement of EIA for all alternatives. More details about EIA and IEE can be found in Ogola (2007) and O'Faircheallaigh (2010).

The main results of the IEE report were presented in a descriptive form constructed in several sections. The descriptions included project impacts (for example on environment, transport, agriculture, fishery, quality of life, etc.), public hearings about the project with local communities as well as preventive and mitigating solutions. There was also a quantitative assessment in the IEE related to the project benefits in monetary terms. The CBA approach was used to assess economic benefits which includes NPV, IRR and B/C ratio. Without considering other important aspects for a public investment project, the best 
alternative based on the existing assessment was alternative $C$ because it had the highest IRR.

\subsubsection{Application}

The application of the proposed IDM to this project case started at the stage of project evaluation. Available data for each alternative were derived from the IEE. For some parameters which were not available in the IEE, information from other external sources was used which will be given references along the application.

\section{Project evaluation}

The attributes are denoted as $C_{1}, C_{2}, C_{3}, C_{4}$ which represent the economic, social, environmental and project support respectively. The evaluation of each attribute is illustrated and described as follows:

\section{I) Economic $\left(C_{l}\right)$}

Based on the IEE information, the economic cost and benefit evaluations were already provided in three measurements which are NPV, IRR and B/C Ratio and therefore there was no need to recalculate them for the use in the economic model. Table 6.2 presents the current economic assessments of each alternative. The monetary unit used in the economic model is in Thai Baht (THB) and the equivalent value of I THB in Euros is approximately 0.027 according to the exchange rate in 2018 .

Table 6.2 Economic assessments of each alternative of the irrigation project

\begin{tabular}{|c|c|c|c|c|}
\hline \multirow{2}{*}{ Criteria } & \multicolumn{4}{|c|}{ Alternative } \\
\cline { 2 - 5 } & A & B & C & D \\
\hline NPV (Million THB) & 134.32 & 20.54 & 87.25 & 18.82 \\
\hline IRR (\%) & 10.77 & 9.16 & 12.26 & 10.57 \\
\hline B/C Ratio & 13.2 & 1.13 & 1.23 & 1.06 \\
\hline
\end{tabular}

According to the earlier explained advantages of NPV over other economic criteria in the economic model of the IDM (see section 5.4.I), the NPV will be used for the comparison among the competing alternatives in the selection part. 


\section{2) Social $\left(C_{2}\right)$}

\section{Population classification}

The first step is to identify the population groups in the project area. To classify the impoverished population groups affected by the project, the income level data for the project area published by NSO (National Statistical Office Thailand, 2006) is used. The NSO income levels are layered over a map of the Yom River Basin boundary to produce a poverty map, representing the percentages of lowincome households in various districts within the project area. The percentages of low-income households were divided into 5 levels, ranging from the lowest $(<5 \%)$ to the highest $(>35 \%)$, as shown in Figure 6.l. Districts with higher percentages of low-income households are populated by more poor people than other areas. Figure 6.I shows the different locations of alternatives and the categorised population groups in each area.

Accordingly the proportion of the population is estimated in percentages and the total percentage of each area is 100 , representing all households affected by each alternative. Table 6.3 illustrates the different population compositions of all alternatives and the priority weights based on the proposed social weights in Table 5.I.

Table 6.3 Population compositions of all alternatives and the priority weights of the irrigation project

\begin{tabular}{|c|c|c|c|c|c|c|}
\hline \multirow{2}{*}{$\begin{array}{c}\text { Population } \\
\text { group }\end{array}$} & \multirow{2}{*}{ Description } & \multirow{2}{*}{$\begin{array}{c}\text { Priority } \\
\text { weight(w) }\end{array}$} & \multicolumn{4}{|c|}{ Proportion of population (P) } \\
\hline & & & $\mathbf{A}$ & B & C & D \\
\hline I & $\begin{array}{l}\text { Very low } \\
\text { income/very } \\
\text { poor }\end{array}$ & $100 \%$ & - & - & - & - \\
\hline 2 & $\begin{array}{l}\text { Low } \\
\text { income/poor }\end{array}$ & $80 \%$ & 20 & - & - & - \\
\hline 3 & Medium income & $60 \%$ & 45 & 50 & 100 & 65 \\
\hline 4 & High income/rich & $20 \%$ & 20 & 50 & - & 35 \\
\hline 5 & $\begin{array}{l}\text { Very high } \\
\text { income/very rich }\end{array}$ & $5 \%$ & 15 & - & - & - \\
\hline & & & $100 \%$ & $100 \%$ & $100 \%$ & $100 \%$ \\
\hline
\end{tabular}




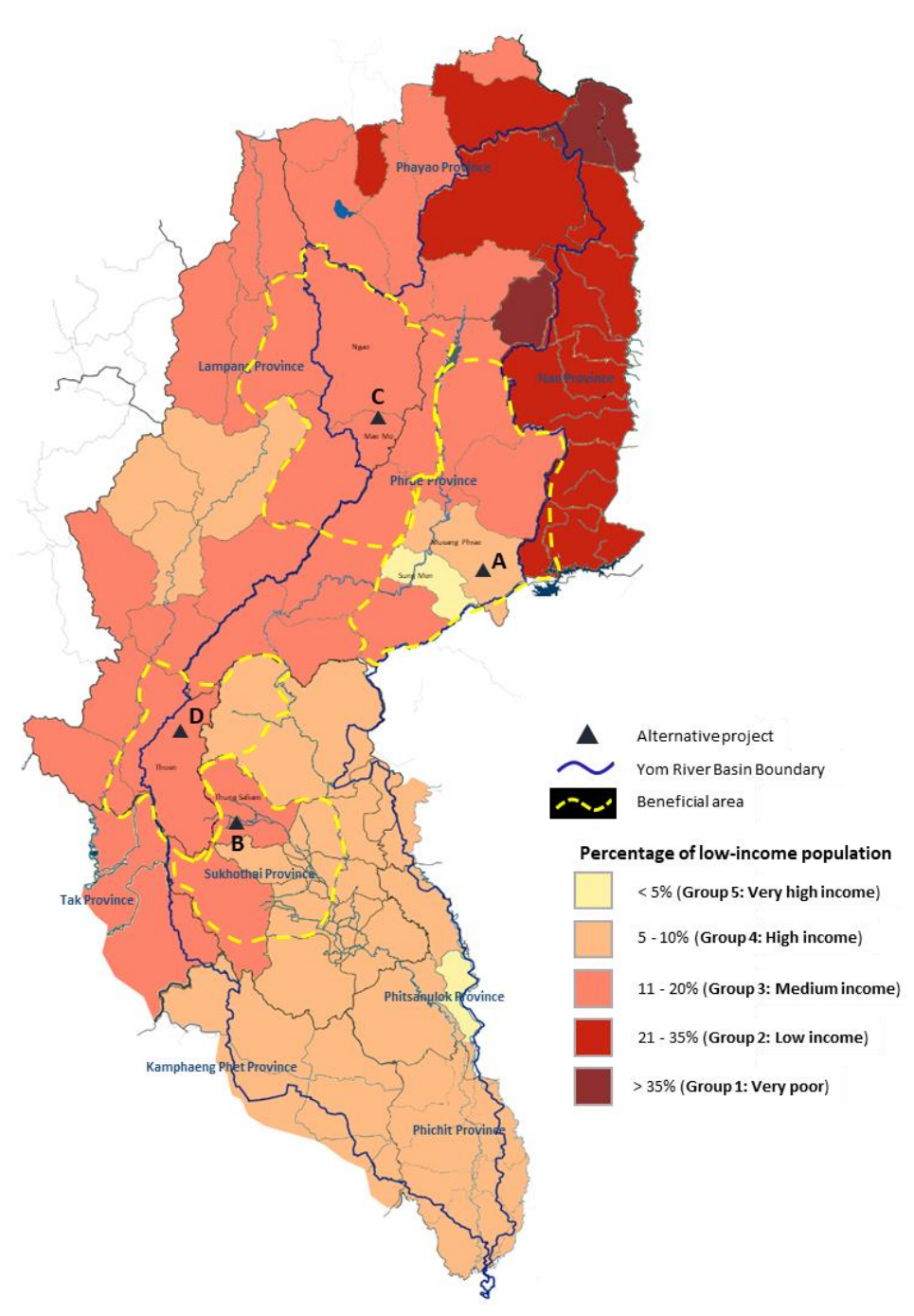

Figure 6.I Locations of alternatives and population groups in the Yom River Basin

The social impacts

The social impacts of a project include two social factors. The first one is the economic impacts (El) of this project involving local income improvements due to developing crop yields and increasing jobs. The second factor is the impact on QoL. This represents the impacts on several issues affecting the communities due to the new reservoir such as water usability, irrigation system and landscape improvements. The authority which carried the original evaluation has no information that can directly be used for the social measure 
adopted by the IDM. For this reason, an experiment has been made by the researchers assuming that people who live in different locations will be subjected to varying degrees of impact. The population groups who live closer to a project location would perceive more benefits than those who live farther away. The social impacts on the two variables on the different population groups for each alternatives are indicated using the rating scale proposed in Table 5.2 as shown in Table 6.4.

Table 6.4 Social impacts (El and QoL) on the affected groups of the irrigation project

\begin{tabular}{|c|c|c|c|c|c|c|c|c|}
\hline \multirow{2}{*}{$\begin{array}{c}\text { Population } \\
\text { group }\end{array}$} & \multicolumn{4}{|c|}{ Economic impacts } & \multicolumn{5}{c|}{ QoL impacts } \\
\cline { 2 - 9 } & A & B & C & D & A & B & C & D \\
\hline I & 0 & 0 & 0 & 0 & 0 & 0 & 0 & 0 \\
\hline 2 & 3 & 0 & 0 & 0 & 4 & 0 & 0 & 0 \\
\hline 3 & 3 & 5 & 5 & 5 & 4 & 5 & 5 & 5 \\
\hline 4 & 5 & 4 & 0 & 4 & 5 & 4 & 0 & 4 \\
\hline 5 & 5 & 0 & 0 & 0 & 5 & 0 & 0 & 0 \\
\hline
\end{tabular}

Calculation of final social scores

The final social score of each alternative is done by applying the formulae (5.3) and (5.4) with the El and QoL scores obtained in Table 6.4 and the priority weights and proportions of population groups in Table 6.3. A calculation example of the final social score of an alternative is shown below:

Alternative $D$ :

Population group $3=[$ El score (5) + QoL score (5) $] \times w_{3}(0.6) \times P_{D 3}(0.65)=3.9$

Population group $4=[$ El score (4) + QoL score (4) $] \times w_{4}(0.2) \times P_{D 4}(0.35)=0.56$

The final social score of each alternative is calculated in the same way and shown in Table 6.5.

Table 6.5 Final social scores for all project alternatives

\begin{tabular}{|c|l|c|c|c|c|}
\hline \multirow{2}{*}{$\begin{array}{c}\text { Population } \\
\text { group }\end{array}$} & \multirow{2}{*}{ Description } & \multicolumn{4}{|c|}{ Alternative } \\
\cline { 3 - 6 } & & A & B & C & D \\
\hline I & Very low income/very poor & 0 & 0 & 0 & 0 \\
\hline 2 & Low income/poor & 1.12 & 0 & 0 & 0 \\
\hline 3 & Medium income & 1.89 & 3 & 6 & 3.9 \\
\hline 4 & High income/rich & 0.4 & 0.8 & 0 & 0.56 \\
\hline 5 & Very high income/very rich & 0.075 & 0 & 0 & 0 \\
\hline $\begin{array}{c}\text { Total final } \\
\text { scores }\end{array}$ & & $\mathbf{3 . 4 9}$ & $\mathbf{3 . 8 0}$ & $\mathbf{6}$ & $\mathbf{4 . 4 6}$ \\
\hline
\end{tabular}


3) Environmental $\left(C_{3}\right)$

The original environmental assessment in this project covered eight important issues which involved two phases of the project, construction phase (shortterm impact) and implementation phase (long-term impact). The existing assessment is shown in Table 6.6 which was expressed in descriptive format but an assessment conclusion was presented for each issue, indicating its positive or negative degree of impact, as being either high, medium, low.

Table 6.6 The environmental assessment summary in the IEE of the project

\begin{tabular}{|c|c|c|c|c|c|c|c|c|}
\hline Alternative & \multicolumn{2}{|c|}{$\mathbf{A}$} & \multicolumn{2}{|c|}{$\mathbf{B}$} & \multicolumn{2}{|c|}{ C } & \multicolumn{2}{|c|}{ D } \\
\hline Issue & $\begin{array}{l}\text { Short- } \\
\text { term }\end{array}$ & $\begin{array}{l}\text { Long- } \\
\text { term }\end{array}$ & $\begin{array}{c}\text { Short- } \\
\text { term }\end{array}$ & $\begin{array}{l}\text { Long- } \\
\text { term }\end{array}$ & $\begin{array}{l}\text { Short- } \\
\text { term }\end{array}$ & $\begin{array}{l}\text { Long- } \\
\text { term }\end{array}$ & $\begin{array}{c}\text { Short- } \\
\text { term }\end{array}$ & $\begin{array}{l}\text { Long- } \\
\text { term }\end{array}$ \\
\hline EI & $\mathrm{L}-$ & $\mathrm{N}$ & $\mathrm{L}-$ & $\mathrm{N}$ & L- & $\mathrm{N}$ & L- & $\mathrm{N}$ \\
\hline E2 & L- & L+ & L- & M+ & L- & M+ & L- & M+ \\
\hline E3 & L- & L- & L- & L- & L- & L- & L- & L- \\
\hline E4 & $\mathrm{N}$ & $\begin{array}{l}\text { L-, } \\
\text { M+* }\end{array}$ & $\mathrm{N}$ & $\mathrm{L}+$ & $\mathrm{N}$ & $\mathrm{L}+$ & $\mathrm{N}$ & $\mathrm{L}+$ \\
\hline E5 & L- & L- & L- & L- & L- & L- & L- & L- \\
\hline E6 & L- & M- & L- & L- & L- & M- & L- & M- \\
\hline E7 & L- & $\mathrm{N}$ & L- & $\mathrm{N}$ & L- & $\mathrm{N}$ & L- & $\mathrm{N}$ \\
\hline E8 & $\mathrm{N}$ & $M+$ & $\mathrm{N}$ & M+ & $\mathrm{N}$ & $M+$ & $\mathrm{N}$ & M+ \\
\hline $\begin{array}{l}\text { Environmental im } \\
\text { EI }=\text { Topographic } \\
\text { E2 }=\text { Ground wat } \\
\text { E3 }=\text { Ground wat } \\
\text { E4 }=\text { Undergroun } \\
\text { E5 }=\text { Soil quality } \\
\text { E6 = Water ecosy } \\
\text { E7 = Forest land } \\
\text { E8 = Wild animals }\end{array}$ & $\begin{array}{l}\text { acts on: } \\
\text { al change } \\
\text { r hydrolo } \\
\text { r quality } \\
\text { I water qu } \\
\text { stem chan }\end{array}$ & $\begin{array}{l}\text { quality } \\
\text { lity }\end{array}$ & & $\begin{array}{l}L=L o v \\
M=M c \\
H=H i \\
N=N c \\
(-)=N \\
(+)=P \\
* \text { This is }\end{array}$ & $\begin{array}{l}\text { ative imp } \\
\text { tive impa } \\
\text { e has } 2 \mathrm{~s}\end{array}$ & -issues & & \\
\hline
\end{tabular}

The descriptive assessment is transformed into a measurable format using the qualitative rating scale proposed in Table 5.4. The assessment based on the IDM is shown in Table 6.7.

Table 6.7 shows that the short-term scores of all alternatives have the same value of (12) which suggests that there is no preference for an alternative as far as the short-term environmental impact. Instead there are differences related to the long-term environmental impact between the various alternatives on the basis of which a selection decision can be made. 
Table 6.7 Environmental assessment based on the qualitative scale

\begin{tabular}{|l|l|l|l|l|l|l|l|l|}
\hline Alternative & \multicolumn{2}{|c|}{ A } & \multicolumn{2}{c|}{ B } & \multicolumn{2}{c|}{ C } & \multicolumn{2}{c|}{ D } \\
\hline Issue & $\begin{array}{c}\text { Short- } \\
\text { term }\end{array}$ & $\begin{array}{l}\text { Long- } \\
\text { term }\end{array}$ & $\begin{array}{c}\text { Short- } \\
\text { term }\end{array}$ & $\begin{array}{c}\text { Long- } \\
\text { term }\end{array}$ & $\begin{array}{c}\text { Short- } \\
\text { term }\end{array}$ & $\begin{array}{l}\text { Long- } \\
\text { term }\end{array}$ & $\begin{array}{c}\text { Short- } \\
\text { term }\end{array}$ & $\begin{array}{l}\text { Long- } \\
\text { term }\end{array}$ \\
\hline EI & 2 & - & 2 & - & 2 & - & 2 & - \\
\hline E2 & 2 & 3 & 2 & 4 & 2 & 4 & 2 & 4 \\
\hline E3 & 2 & 2 & 2 & 2 & 2 & 2 & 2 & 2 \\
\hline E4 & - & 3 & - & 3 & - & 3 & - & 3 \\
\hline E5 & 2 & 2 & 2 & 2 & 2 & 2 & 2 & 2 \\
\hline E6 & 2 & $\mathrm{I}$ & 2 & 2 & 2 & 1 & 2 & I \\
\hline E7 & 2 & - & 2 & - & 2 & - & 2 & - \\
\hline E8 & - & 4 & - & 4 & - & 4 & - & 4 \\
\hline Total score & $\mathbf{I 2}$ & $\mathbf{I 5}$ & $\mathbf{I 2}$ & $\mathbf{I 7}$ & $\mathbf{I 2}$ & $\mathbf{I 6}$ & $\mathbf{I 2}$ & $\mathbf{1 6}$ \\
\hline
\end{tabular}

4) Project Support $\left(C_{4}\right)$

In this model, each alternative needs to be assigned a degree of project support representing the extent to which stakeholders and the local community cooperate and collaborate. The qualitative rating scale in Table 5.6 which is adapted from Choguill's ladder of community participation (Choguill, 1996), is applied to map participation in the project to yield a total project support score.

For the assessment of the project support aspect in the IDM, available information based on the IEE report was used. The information shows that originally all alternatives went through the common public participation controlled by government officials which includes attitude surveys obtained by gathering residents' opinions about the project. In practice, the outcome of such participation are not often used in the decision-making process due to its descriptive nature. However, it is carried out as a rubber-stamp procedure to achieve a semblance of participation and their feedbacks and opinions are not meaningfully considered (Choguill 1996).

For the purpose of applying the IDM in evaluating this attribute, it was clear that all alternatives have a fair level of project support and are therefore assigned with a score of 2 .Table 6.8 presents the project support scores of all alternatives. 
Table 6.8 Project support score of each irrigation project alternative

\begin{tabular}{|c|c|c|}
\hline Alternative & $\begin{array}{c}\text { Level of } \\
\text { support }\end{array}$ & $\begin{array}{c}\text { Project support } \\
\text { score }\end{array}$ \\
\hline A & Fair & 2 \\
\hline B & Fair & 2 \\
\hline C & Fair & 2 \\
\hline D & Fair & 2 \\
\hline
\end{tabular}

\section{Project selection}

I) Construct a decision-making matrix based on the previous results of the evaluation model (economic, social, environmental, project support).

2) All scores in this project are benefit attributes, which can be normalised using formula (5.5) for benefit attributes. Multiply these attributes by 100.

The original and normalised scores in the decision-making matrix are shown in Table 6.9

Table 6.9 MADM matrix and the normalised scores (NS) of all alternatives

\begin{tabular}{|c|c|c|c|c|c|c|c|c|}
\hline \multirow{2}{*}{ Alt. } & \multicolumn{2}{|c|}{$C_{1}$} & \multicolumn{2}{c|}{$C_{2}$} & \multicolumn{2}{c|}{$C_{3}$} & \multicolumn{2}{c|}{$C_{4}$} \\
\cline { 2 - 9 } & NPV* & NS** & $\begin{array}{c}\text { Social } \\
\text { score }\end{array}$ & NS* & $\begin{array}{c}\text { Environmental } \\
\text { impact }\end{array}$ & NS* & $\begin{array}{c}\text { Support } \\
\text { degree }\end{array}$ & NS* \\
\hline A & 134.32 & 100 & 3.49 & 58.08 & 15 & 88 & 2 & 100 \\
\hline B & 20.54 & 15.29 & 3.80 & 63.33 & 17 & 100 & 2 & 100 \\
\hline C & 87.25 & 64.96 & 6 & 100 & 16 & 94 & 2 & 100 \\
\hline D & 18.82 & 14.01 & 4.46 & 74.33 & 16 & 94 & 2 & 100 \\
\hline
\end{tabular}

*Unit $=$ Million THB

$* * \mathrm{NS}=$ Normalised score

3) Importance weights were assigned to the economic, social, environmental and project support attributes by a decision-maker of the RID with regards to the project objective which is to improve the local people's water situation and environment, and are presented in the following weight vector:

$W=[0.2,0.3,0.3,0.2]=1$

4) Calculate the evaluation score for each alternative using formula (5.7). The final weighted scores are shown in Table 6.I0. 
Table 6. I0 Evaluation scores for all alternatives of the irrigation project

\begin{tabular}{|c|c|c|c|c|c|c|}
\hline Alternative & $\boldsymbol{C}_{\boldsymbol{l}}$ & $\boldsymbol{C}_{\boldsymbol{2}}$ & $\boldsymbol{C}_{\mathbf{3}}$ & $\boldsymbol{C}_{\boldsymbol{4}}$ & $\begin{array}{c}\text { Weighted } \\
\text { scores }\end{array}$ & Rank \\
\hline A & 20 & 17.42 & 26.40 & 20 & 83.82 & 2 \\
\hline B & 3.06 & 19 & 30 & 20 & 72.06 & 4 \\
\hline C & 12.99 & 30 & 28.20 & 20 & 91.19 & I \\
\hline D & 2.8 & 22.30 & 28.20 & 20 & 73.30 & 3 \\
\hline
\end{tabular}

5) The alternatives are ranked from the highest to lowest score based on the final weighted scores shown in last column of Table 6. I0.

Based on the results, alternative $C$ has the highest score (91.19), meaning it comes in first place. Alternative $A$ comes in second due to its slightly lower score (83.82), followed by alternatives $D(73.30)$ and $B(72.06)$ respectively.

\subsubsection{Discussion}

The application of the IDM to this project served to demonstrate how the proposed methods and decision model included in the methodology are applied in order to evaluate an investment in a public infrastructure project with various alternatives.

Based on the methodology structure in Chapter 5 (Figure 5.I), the application of the IDM to this project case demonstrates its effectiveness in terms of ease of use, adaptability and flexibility, as well as how it improves the current evaluation and selection process. It indicates the usefulness of IDM which represents substantial improvement on the current procedure because it provides more insight on how the alternatives impact social and environmental issues.

In the original case, the assessment was based on IRR to compare choices on an economic basis. As shown in Table 6.2, however, the economic assessment based on the proposed IDM has indicated that the alternative that produces the highest IRR does not necessarily result in the highest NPV. Hence, on the basis of economic assessment, alternative $A$ and not alternative $C$, as the original assessment suggested, should be selected, since it produces the highest positive NPV.

The application case has also shown, that in this project, the area affected by Yom River Basin, including many provinces in northern region of the country, is very large. The size of the project indicates the complexity of the communities affected by the proposed project alternatives. The use of population 
compositions based on income level in the social model helps to manage such complexity and provides a clearer picture of the possible interactions between each alternative and the community groups affected by it. Such interaction is represented in the results of the final social scores. Alternative $C$ produces the highest social score due to the fact that this alternative affects the largest poorer communities due to which it is assigned a higher priority weight in the model.

The use of the qualitative rating scale by the IDM can also enhance the common environmental assessment and public participation in the IEE report. The current IEE was primarily descriptive and difficult to be used in a decisionmaking. Different issues in the environmental assessment were summarised and transformed using the proposed scale into a single matrix. The extent of stakeholders and local community participation in the project is determined by measuring their support level. This has made the assessment simpler and easier to analyse and compare.

The final selection decision on the best alternative is then achieved using the SAW model. According to current practice in Thailand, project evaluation and selection is mainly carried out by evaluators or project analysts in an organisation and has minimum involvement from executive decision makers. The IDM demonstrates its suitability to be used within such practice. A decision maker's preference is required only at the last stage in order to assign the attributes weights to be applied in the SAW model.

Comparing the final results from the original existing assessment with the results produced by the IDM, it is clear that the best alternative based on both methods is still alternative $C$, even though the original assessment was only based on an economic model. Alternative $C$ does not only obtain the highest IDM score due to its economic score, but also to its social and environmental scores, which means the fact that the original assessment and IDM results are identical, in this case, it is a mere coincidence. the results from IDM also indicate that the project support attribute has insignificant effect on the final score, since all alternatives were given the same performance score for this attribute.

Even though the results from the developed IDM on this project case are not different from those originally produced by current practice, they however supply the decision maker with more information to make the investment decision transparent. The IDM uses existing evaluation and selection techniques (e.g. NPV, SAW, qualitative measurement), however it integrates them in a 
single decision model for the decision maker to see the effect of changes made in one attribute on the final decision. Also the methodology does not intend to convert all the attributes values into financial scores but instead it leaves them in their own units and then convert the values into unitless scores for the purpose of comparison. Moreover the main novel idea of the methodology is the way social aspects are evaluated. The paper describes how the IDM models the social variables and the impacts on the local community to allow the decision makers examining the interactions between the project and the conditions of the community.

Furthermore, the IDM can also enhance the descriptive nature of the EIA/IEE for a more meaningful and clearer result. This case is on condition that the EIA/IEE is organised before the selection is made. In cases that EIA/IEE is made after the selection, it can be used to recheck the results from the IDM by giving more information for each evaluation aspect. Incorporating the information from the EIA/IEE into the evaluation process is suggested in this paper. However, the ranking of impacts could be problematic where very significant social and environmental impacts to critical species and habitats would be diluted by attributing numbers to all the factors. A recommendation can be that the experts who perform the EIA/IEE process should seriously regard the investment objectives and work closely with project evaluators in order to examine how these critical issues can be adequately addressed.

Moreover, as a result of the insignificant project support attribute in this project, we suggest to improve the existing way of incorporating stakeholders and communities. This will result in a meaningful participation as well as the assessment of the extent of community support. There are various participatory approaches which could be separately applied to conduct this issue. For example the use of participatory MCDA in which values of different parties are devised (see e.g. Scott, 2005; Salgado et al., 2009); or applying the Social License to Operate (SLO) in participatory activities in order to achieve the acceptance or approval by indigenous people in a certain area (see e.g. Demuijnck \& Fasterling, 2016; Wilburn \& Wilburn, 201I). 


\subsection{CASE 2: A Bypass Road Project in Chachoengsao Province, Thailand}

Project owner: Department of Highways (DoH), Ministry of Transport

\subsection{Project description}

Chachoengsao is a province to the east of Bangkok, the capital of Thailand. Chachoengsao is like the first door for most road vehicles travelling from the capital to the east and northeast of the country. In the past, there were only two main routes that passed through Chachoengsao town (Mueang District). In the last few years, the number of vehicles using these routes was increasing and the town was growing but the possibility to expand the roads was limited. This caused traffic jams in many areas of the routes heading to the town. The DoH, an agency responsible for this problem came up with the idea of building a bypass road around the Chachoengsao town to avoid the busy traffic inside the town and reduce travelling time for travelers and traders going to other provinces.

The bypass road project involved 5 districts in the province, namely Mueang, Bang-Nam-Priao, Khlong-Khuean, Bang-Khla, and Ban-Pho.

The project consisted of three parts, with each part having two alternatives, as described below and shown in Figure 6.2.

- Northern part, stretching from point $X$ to $Y$, Alternative $A$ and Alternative $B$

- Eastern part, stretching from $Y$ to $Z$, Alternative $C$ and Alternative $D$

- Southern part, stretching from $X$ to $Z$, Alternative $E$ and Alternative $F$

To complete the entire road, the DoH had to choose the best alternative for each part. As a result of the objective, this project comprises of 3 sub-projects which are: I) $\boldsymbol{A}$ against $\boldsymbol{B}, 2) \boldsymbol{C}$ against $\boldsymbol{D}$ and 3) $\boldsymbol{E}$ against $\boldsymbol{F}$.

Three attribute aspects were used: engineering, economic, and environmental aspects. The engineering aspect was concerned with traffic flows and road construction efficiency, which was obtained from a traffic model developed prior the evaluation. The economic aspect involved comparing the total project costs of the competing alternatives. The environmental aspect involved many environmental issues relating to for example, affected local properties, number of sensitive areas, mangrove forests, and other affected infrastructures. 
The methods that DoH used to evaluate each alternative were scoring and multi-criteria/attribute decision analysis (MCDA/MADA), with criteria/attribute importance weights. All attributes were measured in different units and were later transformed to the same scale based on the measurement scale shown in Table 6.I I. The existing measurement scale was applied to all attributes values that were presented in both numerical measures and qualitative terms. The adjusted score of each attribute was multiplied with the attribute weights assigned to engineering, economic and environmental: $35 \%, 30 \%$ and $35 \%$, respectively.

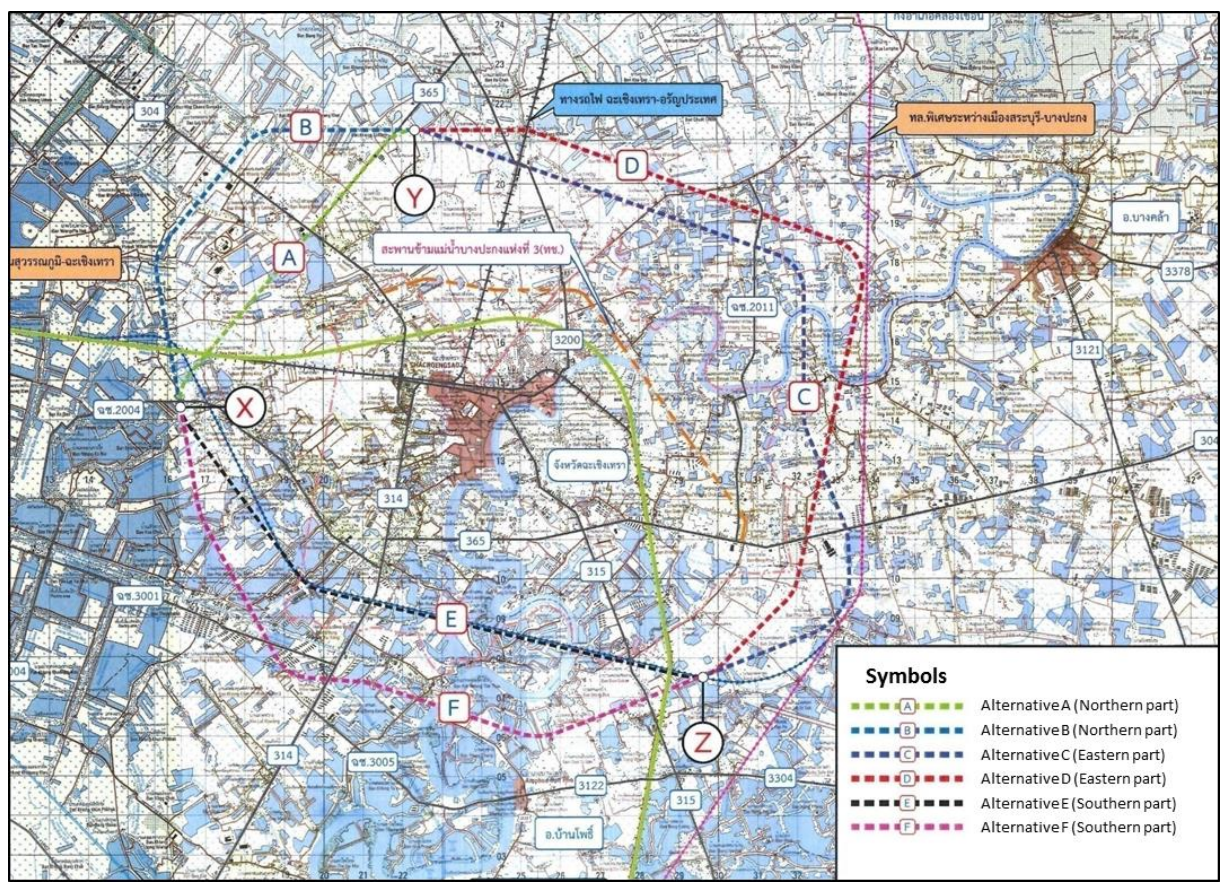

Figure 6.2 A bypass road project location and alternatives

Table 6.I I Existing measurement scale for a bypass project

\begin{tabular}{|c|l|l|c|}
\hline No. & \multicolumn{1}{|c|}{ Numerical measure } & Qualitative measure & Score \\
\hline I & $\begin{array}{l}\text { The best value or lower than the } \\
\text { best value not over than 10\% }\end{array}$ & Very appropriate & 1.0 \\
\hline 2 & Lower than the best value 10 - 20\% & Appropriate & 0.8 \\
\hline 3 & Lower than the best value 2I - 40\% & Fairly appropriate & 0.6 \\
\hline 4 & $\begin{array}{l}\text { Lower than the best value 4I - 60\% } \\
\text { Lower than the best value more than }\end{array}$ & Not appropriate & 0.4 \\
\hline 5 & Not at all appropriate & 0.2 \\
\hline
\end{tabular}


Based on this information, the alternatives that had the highest score in each part of the project were selected, namely alternatives $A, C$ and $F$.

In the following sections, the evaluation of the Bypass Road Project in the Chachoengsao province is conducted by applying the proposed IDM. The existing information will be used in the model to reach the final score for each alternative. The results of the original assessment and the proposed IDM will be analysed at the end of this project case.

\subsubsection{Application}

The application starts at the stage of project evaluation and selection by assuming that all alternatives passed all prior stages (reviewing investment idea, prerequisite checklist). In the original assessment, the three attributes, namely engineering, economic, and environmental, were used, as mentioned in the project description, but the social and project support attributes, which are also important aspects for public investment decision, were missing. The IDM applied to this project follows the proposed four important evaluation attributes, which are economic, social, environmental and project support and will also include the engineering assessment in the evaluation. How to include these aspects in the proposed IDM will be explained along with the application of each evaluation model.

Like in the water project case, the existing information is used as much as necessary, but, in some cases, external information will be necessary to complete some variables in the model, specifically the social model, as it did not exist in the original system.

\section{Project evaluation}

The attributes are denoted as $C_{1}, C_{2}, C_{3}, C_{4}$, which represent the economic, social, environmental and project support respectively. The evaluation of each attribute is illustrated and described in what follows:

I) Economic $\left(C_{l}\right)$

The economic aspect of this project, as mentioned in the project description, consisted only of the project costs of each alternative. No other information, such as monetary benefits per year and a time-discounted parameter, was provided to perform an NPV calculation for this project. In the case that only cost is available, the methodology suggests the use of a cost-effectiveness analysis (CEA) to measure economic effects (see the review and reasons for 
using CEA in section 2.4.2 and 5.4.1). Nevertheless, the CEA still requires that a project benefit or outcome be available to properly perform the calculation. The benefit can be a goal or objective that a project wants to achieve. Based on the project description, the objective of this project is to improve traffic inside the town and to reduce total travelling time driving on the route, and the original assessment of the engineering aspect also provided relevant information about these issues. The information specified the benefit in terms of project efficiency involving two issues: travel distance saving and travel time saving. An alternative that has lower cost and higher benefit value is the better from an efficiency perspective.

Based on the data described, the benefits and cost of each alternative to be used for the CEA are illustrated in Table 6.12.

Table 6.1 2 Cost and benefits of the bypass project

\begin{tabular}{|c|l|c|c|c|c|c|c|}
\hline \multirow{2}{*}{ Cost } & \multicolumn{6}{|c|}{ Alternative } \\
\cline { 3 - 8 } & & A & B & C & D & E & F \\
\hline Cl & Project cost (million THB) & 3,932 & 4,284 & 6,292 & 6,326 & 6,387 & 7,708 \\
\hline & \multicolumn{1}{|c|}{ Benefit } & A & B & C & D & E & F \\
\hline BI & $\begin{array}{l}\text { Saving travel distance } \\
\text { (PCU-km.) }\end{array}$ & 140,741 & $179,7 \mid 4$ & 219,448 & 205,561 & 219,678 & 204,423 \\
\hline B2 & $\begin{array}{l}\text { Saving travel time } \\
\text { (PCU-hour) }\end{array}$ & 29,692 & 31,909 & 28,007 & 26,915 & 31,846 & 29,547 \\
\hline
\end{tabular}

Table 6.12 shows two benefits from an engineering perspective, represented in different units and set solely against the total cost of each alternative. Thus, the total cost is used for both benefits to show their outcomes, set against cost. For a proper CEA analysis, the two dimensions of benefit need to be combined into one benefit value, which requires that are expressed in the same unit. This means they must be normalised into the same scale, so that they can be combined into a single value (Pavličić, 200I). Once the two benefits are combined into one value, the CEA calculation can be performed. The CEA result is presented as a ratio of incremental cost to incremental benefit (Shaner, 1979; Sanders, et al., 2016).

Example calculation of CEA for alternative $A$ is:

Project cost $A /$ Benefit value $A \quad=3,932 / 171.37=22.95$

Thus, the CEA of alternative $A$ is 22.95 , which means that one unit of incremental benefits produced by $A$ will cost 22.95 million THB. 
Table 6.13 presents the normalised values of benefits and the CEA result for each alternative. The CEA results present in monetary terms which alternative is considered to be more economically efficient.

Table 6.13 Cost-effectiveness analysis of the bypass project

\begin{tabular}{|c|c|c|c|c|c|c|c|}
\hline \multirow{2}{*}{ Cost } & \multicolumn{7}{|c|}{ Alternative } \\
\cline { 3 - 8 } & & A & B & C & D & E & F \\
\hline Cl & Project cost (million THB) & 3,932 & 4,284 & 6,292 & 6,326 & 6,387 & 7,708 \\
\hline & & & & & & & \\
\hline & Normalised value of benefit & A & B & C & D & E & F \\
\hline BI & Saving travel distance & 78.31 & 100 & 100 & 93.67 & 100 & 93.06 \\
\hline B2 & Saving travel time & 93.05 & 100 & 100 & 96.10 & 100 & 92.78 \\
\hline & Total normalised benefit & 171.37 & 200 & 200 & 189.77 & 200 & 185.84 \\
\hline & Cost-effectiveness (million THB) & $\mathbf{2 2 . 9 5}$ & $\mathbf{2 1 . 4 2}$ & $\mathbf{3 1 . 4 6}$ & $\mathbf{3 3 . 3 3}$ & $\mathbf{3 1 . 9 3}$ & $\mathbf{4 1 . 4 8}$ \\
\hline
\end{tabular}

2) Social $\left(C_{2}\right)$

This section demonstrates the steps in the proposed social model which are applied to this project with regard to three social aspects. The information and variables used for each aspect are described first, after which ways to combine these aspects and variables to derive the social impact of each alternative are detailed.

The income level of the population affected by the project

As mentioned in the project description, the project consists of 3 sub-projects, which are expected to be connected into one route. Although each sub-project is geographically located in different districts, they all share the same target groups and the same project area.

To help carry out the social evaluation, the external information is used to classify the poverty population groups of the project, consisting of income level data for the project area published by NSO (National Statistical Office Thailand, 2006). The NSO income level data represents percentages of low-income households in various districts within the project area. The percentages of lowincome households were divided into 5 levels, ranging from the lowest $(<5 \%)$ to the highest (>35\%). Districts that have higher percentages of low-income households are home to more poor people.

Based on the data from the NSO, there are 3 population groups (medium income, high income, very high income) in the project area. According to the proposed social model in the IDM, the population groups based on income level 
in Table 5.I are applied and the proportion of each group is estimated in percentage terms, as a part of the total percentage of 10 , representing the total target population of the project. Table 6.14 illustrates the population composition of the area and the priority weights based on the proposed social weights in Table 5.I. As presented in Table 6.14, there are no in low-income and very low-income population groups in the project area. Therefore, the calculation of the social model will not include these 2 groups but will be based on the proportions and priority weights of the others, which are the medium income, high income, and very high income population groups.

Table 6.14 Population compositions and priority weights of the project

\begin{tabular}{|c|l|l|c|c|}
\hline $\begin{array}{c}\text { Population } \\
\text { group }\end{array}$ & \multicolumn{1}{|c|}{ Description } & District & $\begin{array}{c}\text { Proportion } \\
\text { (\%) }\end{array}$ & $\begin{array}{c}\text { Priority } \\
\text { weight(\%) }\end{array}$ \\
\hline 1 & Very low income/very poor & - & - & 100 \\
\hline 2 & Low income/poor & - & - & 80 \\
\hline 3 & Medium income & $\begin{array}{l}\text { - Bang-Nam- } \\
\text { Priao } \\
\text { Khlong- } \\
\text { Khuean }\end{array}$ & 40 & 60 \\
\hline 4 & High income/rich & $\begin{array}{l}\text { - Mueang } \\
\text { - Ban-Pho }\end{array}$ & 40 & 20 \\
\hline 5 & Very high income/very rich & - Bang-Khla & 20 & 5 \\
\hline
\end{tabular}

Economic impact on the population

This aspect serves to measure the local economic impact (EI) of each alternative on different population groups. The El of this project involves local income improvements due to new jobs and more businesses during and after the construction of the new roads. We assume that even though all population groups live in the same project area, different locations in the area might be subjected to varying degrees of impact. This is based on the assumption that people who live close to the alternative location would reasonably have easier and faster access to the road and its benefits than those who live further away. Thus, the population groups living close by will receive a higher positive El impact on per capita income ( $\mathrm{PCl})$ from the project than the other groups.

To indicate the impact levels, the rating scale in Table 5.2 is applied. The rating scale is measured in an ordinal scale from 0 to 5 , with higher numbers representing greater impact. 
In a local area where a project area is small, the impact of an alternative on people living in various nearby locations might be very similar, making it difficult to determine the actual impact. Most social impact is often assessed in an arbitrary manner and the rating scale can assist a decision-maker to quantify that feeling into a number. Applying the proposed rating scale can be discrete, using integers such 2, 3, 5, as proposed, or with decimal numbers between two variables, such as median values (e.g. 4.5, 3.5, 2.5). The decimals numbers help indicate a small difference of impact between various target groups who live in adjacent neighbourhoods.

El scores can be shown by including additional information and adding a layer of the alternative routes from the DoH in Figure 6.2 over a map of the district boundaries in the project area, so that the population groups can be identified together with the alternative routes. The indication of the El impact of alternative $F$ can be used as an example, as shown below:

Table 6.I5 Example of indicating local economic impact

\begin{tabular}{|l|l|l|l|l|}
\hline \multicolumn{1}{|c|}{ Alternative $\boldsymbol{F}$} & \multicolumn{1}{|c|}{ District } & Population & Positive impact & Score \\
\hline Locations & $\begin{array}{l}\text { Mueang } \\
\text { Ban-Pho }\end{array}$ & Group 4 & High & 5 \\
\hline Adjacent locations & Bang-Khla & Group 5 & Low + & 3.5 \\
\hline Distant locations & $\begin{array}{l}\text { Khlong-Khuean } \\
\text { Bang-Nam-Priao }\end{array}$ & $\begin{array}{l}\text { Group 3 } \\
\text { Group 3 }\end{array}$ & $\begin{array}{l}\text { Low } \\
\text { Medium }\end{array}$ & 3 \\
\hline
\end{tabular}

Therefore, based on the example in Table 6.15, alternative $F$ impacts population groups 3, 4 and 5 with the scores 3, 5 and 3.5 respectively. The El of other alternatives are organised in the same way as alternative $F$ and the results are shown in Table 6.16.

Table 6.16 Economic impacts on the affected groups of the bypass project

\begin{tabular}{|c|c|c|c|c|c|c|}
\hline \multirow{2}{*}{ Population group } & \multicolumn{7}{|c|}{ Alternative } \\
\cline { 2 - 7 } & A & B & C & D & E & F \\
\hline 3 & 3 & 3 & 4 & 4 & 3 & 3 \\
\hline 4 & 4 & 4 & 4 & 4 & 4.5 & 5 \\
\hline 5 & 3 & 3 & 4 & 4 & 3.5 & 3.5 \\
\hline
\end{tabular}


The impact on the quality of life of the population

The QoL of the project involves an improvement of accessibility to other public services and facilities when new roads are realised or built. In the same way as with the assessment of the El, the population groups living close to the alternative location will be given higher impact levels. The rating scale in Table 5.2 is applied to indicate the QoL impact of each alternative, following the same method used in the previous El assessment. Table 6.17 shows the impact on QoL of each alternative, broken down according to different population groups.

Table 6.17 Impacts on quality of life on the affected groups of the bypass project

\begin{tabular}{|c|c|c|c|c|c|c|}
\hline \multirow{2}{*}{ Population group } & \multicolumn{7}{|c|}{ Alternative } \\
\cline { 2 - 7 } & A & B & C & D & E & F \\
\hline 3 & 3 & 3 & 4 & 5 & 3 & 3 \\
\hline 4 & 4 & 4 & 4.5 & 4 & 5 & 5 \\
\hline 5 & 3 & 3 & 4.5 & 4.5 & 3 & 3.5 \\
\hline
\end{tabular}

Calculation of final social scores

The last step of the social model is to combine all social attributes and variables to reach the final social score. The calculation of the final social score by applying formulae (5.I) and (5.2) in chapter 5. The example of calculating the final social score of an alternative is shown below:

Alternative $F$ :

Population group $3=[$ El score (3) + QoL score (3) $] \times w_{3}(0.6) \times P_{F 3}(0.4)=1.44$

Population group $4=[$ El score (5) + QoL score (5) $] \times w_{4}(0.2) \times P_{F 4}(0.4)=0.80$

Population group $5=[$ El score (3.5) + QoL score $(3.5)] \times w_{5}(0.05) \times P_{F 5}(0.20)=0.07$

The final social score of each alternative is calculated in the same way as alternative $F$ and the results are shown in Table 6.18.

Table 6.I 8 Final social scores for all alternatives of the bypass project

\begin{tabular}{|c|c|c|c|c|c|c|}
\hline \multirow{2}{*}{ Population group } & \multicolumn{7}{|c|}{ Alternative } \\
\cline { 2 - 7 } & A & B & C & D & E & F \\
\hline 3 & 1.44 & 1.44 & 1.92 & 2.16 & 1.44 & 1.44 \\
\hline 4 & 0.64 & 0.64 & 0.68 & 0.64 & 0.76 & 0.80 \\
\hline 5 & 0.06 & 0.06 & 0.09 & 0.09 & 0.07 & 0.07 \\
\hline Total final scores & $\mathbf{2 . 1 4}$ & $\mathbf{2 . 1 4}$ & $\mathbf{2 . 6 9}$ & $\mathbf{2 . 8 9}$ & $\mathbf{2 . 2 7}$ & $\mathbf{2 . 3 1}$ \\
\hline
\end{tabular}


3) Environmental $\left(C_{3}\right)$

The original environmental assessment of this project involved environmental impact on 7 issues (EI - E7), measuring each issue in a numerical unit as shown in Table 6.19. The overall objectives with regard to these issues are related to disruptions to existing infrastructure, as well as parts of the environment and communities possibly affected by the project. The higher the value of each issue, the greater the negative impact of the project on that issue. The original assessment of each issue was based on a "numerical measure scale", comparing the value of an alternative with the best value of other competing alternatives, as described in the original numerical scale in Table 6.1I in the project description section. Moreover, $35 \%$ of the importance weight was assigned to the environmental aspect. Table 6.19 also presents the original importance weights given to all impact issues.

Table 6.19 Environmental impact issues and numerical measurement units

\begin{tabular}{|c|c|c|c|}
\hline No. & Environmental impact issues & $\begin{array}{l}\text { Numerical } \\
\text { measurement unit }\end{array}$ & $\begin{array}{l}\text { Importance } \\
\text { weights }\end{array}$ \\
\hline EI & Size of expropriated land & Rai* & 6 \\
\hline E2 & Local properties removed & $\begin{array}{c}\text { Number of } \\
\text { houses/buildings }\end{array}$ & 6 \\
\hline E3 & Communities affected in 500 meters & Number of communities & 5 \\
\hline E4 & Sensitive areas affected in 500 meters & Number of sensitive areas & 5 \\
\hline E5 & Archaeological sites affected in $2 \mathrm{~km}$. & $\begin{array}{l}\text { Number of archaeological } \\
\text { sites }\end{array}$ & 5 \\
\hline E6 & Intersections of water ways & Number of intersections & 3 \\
\hline \multirow[t]{2}{*}{ E7 } & $\begin{array}{l}\text { Intersections of other highways/local } \\
\text { roads }\end{array}$ & Number of intersections & 5 \\
\hline & & & 35 \\
\hline
\end{tabular}

$*$ Rai $=$ Unit of area equal to I,600 square metres

Based on the proposed IDM, the environmental assessment should be simple, but still reflect the overall environmental impact of the project. To apply the IDM, the existing scores and the importance weights of all issues need to be adjusted/transformed to be consistent with the methods in the proposed IDM and its principles.

Adjusting the existing scores and the importance weights of all issues Firstly, the scores based on the existing scale are mapped with the qualitative rating scale (scores from $0-5$ ) of the environmental aspect proposed in Table 5.4 , which includes the degrees of impact, representing negative $(0-2)$ and positive impact $(3-5)$ on the environment. For this project, only the negative 
degrees of impact (scores from $0-2$ ) will be used to assess environmental impact, because all impact issues are related to disruptions that will degrade the existing environment, as described earlier. The mapping of original measurement scale with the proposed negative impact rating scale is shown in Table 6.20.

Table 6.20 Mapping of original scale and the proposed rating scale for environmental assessment

\begin{tabular}{|c|c|c|c|}
\hline \multicolumn{2}{|c|}{ Existing measurement scale } & \multicolumn{2}{|c|}{ Proposed rating scale } \\
\hline Numerical measure & Score & $\begin{array}{c}\text { Environmental } \\
\text { impact } \\
\text { (negative scale) }\end{array}$ & Score \\
\hline $\begin{array}{l}\text { The best value or lower than the best } \\
\text { value not over than } 10 \%\end{array}$ & 1.0 & \multirow[t]{2}{*}{ Low degradation } & \multirow[t]{2}{*}{2} \\
\hline Lower than the best value $10-20 \%$ & 0.8 & & \\
\hline Lower than the best value $21-40 \%$ & 0.6 & \multirow{2}{*}{ Medium degradation } & \multirow{2}{*}{1} \\
\hline Lower than the best value $4 \mathrm{I}-60 \%$ & 0.4 & & \\
\hline $\begin{array}{l}\text { Lower than the best value more than } \\
60 \%\end{array}$ & 0.2 & High degradation & 0 \\
\hline
\end{tabular}

Consequently, the original scores will be replaced by the proposed scores. Table 6.2I presents the original scores (E) using the numerical scale and the adjusted scores (AS) based on the new proposed rating scale for environmental assessment. The adjusted scores in Table 6.21 will be used for the final calculation of environmental score.

Table 6.2 I Adjusted environmental scores based on the proposed scale

\begin{tabular}{|c|c|c|c|c|c|c|c|c|c|c|c|c|}
\hline \multirow{3}{*}{ No. } & \multicolumn{12}{|c|}{ Alternatives } \\
\hline & \multicolumn{2}{|c|}{$\mathbf{A}$} & \multicolumn{2}{|c|}{ B } & \multicolumn{2}{|c|}{ C } & \multicolumn{2}{|c|}{$\mathbf{D}$} & \multicolumn{2}{|c|}{$\mathbf{E}$} & \multicolumn{2}{|c|}{$\mathbf{F}$} \\
\hline & $E$ & $A S$ & $E$ & $\overline{A S}$ & $E$ & $\overline{A S}$ & $E$ & $\overline{A S}$ & $E$ & $\overline{A S}$ & $E$ & $A S$ \\
\hline $\mathrm{EI}$ & $\mathrm{T}$ & 2 & 0.4 & $\mathrm{~T}$ & $\mathrm{I}$ & 2 & $\mathrm{~T}$ & 2 & 0.2 & 0 & $\mathrm{~T}$ & 2 \\
\hline E2 & $\mathrm{I}$ & 2 & 0.2 & 0 & $\mathrm{I}$ & 2 & 0.2 & 0 & 0.6 & $\mathrm{I}$ & $\mathrm{I}$ & 2 \\
\hline E3 & $T$ & 2 & 0.4 & $T$ & 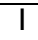 & 2 & $\mathrm{I}$ & 2 & $\mathrm{~T}$ & 2 & 0.8 & 2 \\
\hline E4 & $T$ & 2 & $T$ & 2 & 1 & 2 & 0.2 & 0 & $T$ & 2 & 0.8 & 2 \\
\hline E5 & 0.2 & 0 & $\mathrm{I}$ & 2 & $\mathrm{I}$ & 2 & 0.4 & $\mathrm{I}$ & $\mathrm{I}$ & 2 & $\mathrm{I}$ & 2 \\
\hline E6 & $\mathrm{I}$ & 2 & 0.4 & $\mathrm{I}$ & $\mathrm{I}$ & 2 & 0.6 & $\mathrm{I}$ & 0.8 & 2 & $\mathrm{I}$ & 2 \\
\hline E7 & $\mathrm{I}$ & 2 & $\mathrm{I}$ & 2 & $\mathrm{I}$ & 2 & 0.6 & $\mathrm{I}$ & 0.6 & $\mathrm{I}$ & $\mathrm{I}$ & 2 \\
\hline
\end{tabular}

$\mathrm{E}=$ Existing score $\mathrm{AS}=$ Adjusted score based on the proposed rating scale

Furthermore, the current importance weights of all issues based on the total environmental weight (35\%) need to be adjusted. The total weight of $35 \%$ is rescaled to $100 \%$. This is suggested because the distributional weights among attributes (e.g. economic, environmental, social) can be changed at any time, 
which means the environmental weight will not always be $35 \%$. The adjusted weights of all environmental issues are shown in Table 6.22.

Table 6.22 Adjusted weights for all environmental issues

\begin{tabular}{|c|c|c|}
\hline Issue no. & Original weights & $\begin{array}{c}\text { Adjusted weights } \\
\text { (AW) }\end{array}$ \\
\hline$E I$ & 6 & 17.14 \\
\hline$E 2$ & 6 & 17.14 \\
\hline$E 3$ & 5 & 14.29 \\
\hline$E 4$ & 5 & 14.29 \\
\hline$E 5$ & 5 & 14.29 \\
\hline$E 6$ & 3 & 8.57 \\
\hline$E 7$ & 5 & 14.29 \\
\hline Total (\%) & $\mathbf{3 5}$ & 100 \\
\hline
\end{tabular}

With the given adjusted scores (AS) and adjusted weights (AW) of all environmental issues in Table 6.2I and 6.22, the final environmental score of each alternative can be calculated by multiplying a score (AS) and the weight (AW) of each issue (EI - E7) and combining them.

\section{For example:}

The environmental score of alternative $A=$ $(2 \times 0.1714)+(2 \times 0.1714)+(2 \times 0.1429)+(2 \times 0.1429)+(0 \times 0.1429)+(2 \times 0.0857)+(2 \times 0.1429)$ $=1.7144$

Table 6.23 illustrates the final score of each issue and the total environmental evaluation score of each alternative in two decimal places.

Table 6.23 Environmental evaluation scores for all bypass project alternatives

\begin{tabular}{|c|c|c|c|c|c|c|}
\hline \multirow{2}{*}{ Issue no. } & \multicolumn{7}{|c|}{ Alternatives } \\
\cline { 2 - 7 } & $\mathbf{A}$ & $\mathbf{B}$ & $\mathbf{C}$ & $\mathbf{D}$ & $\mathbf{E}$ & $\mathbf{F}$ \\
\hline EI & 0.34 & 0.17 & 0.34 & 0.34 & 0 & 0.34 \\
\hline E2 & 0.34 & 0 & 0.34 & 0 & 0.17 & 0.34 \\
\hline E3 & 0.29 & 0.14 & 0.29 & 0.29 & 0.29 & 0.29 \\
\hline E4 & 0.29 & 0.29 & 0.29 & 0 & 0.29 & 0.29 \\
\hline E5 & 0 & 0.29 & 0.29 & 0.14 & 0.29 & 0.29 \\
\hline E6 & 0.17 & 0.09 & 0.17 & 0.09 & 0.17 & 0.17 \\
\hline E7 & 0.29 & 0.29 & 0.29 & 0.14 & 0.14 & 0.29 \\
\hline Total score & $\mathbf{I . 7 I}$ & $\mathbf{I . 2 6}$ & $\mathbf{2 . 0 0}$ & $\mathbf{I . 0 0}$ & $\mathbf{I . 3 4}$ & $\mathbf{2 . 0 0}$ \\
\hline
\end{tabular}


4) Project support $\left(C_{4}\right)$

The project support attribute represents stakeholder and local community participation and involvement. The qualitative rating scale in Table 5.6 is applied to map the participation methods used in the project to the degree of project support.

Originally, public participation was not included in the existing assessment of this project, but it was considered as part of the project proposal, in order to meet the required regulations. Like in the water project, the information shows that project analysts and consultants of the DoH had carried out the public participation for all alternatives by using the formal methods controlled by the government office, which consists attitude surveys carried out by visiting the neighbourhood and gathering their opinions about the project, as well as meetings with residents and public local executives.

Based on the methods used referring to the qualitative scale for project support in Table 5.6, all alternatives can indicate a fair level of project support with a degree of 2. Table 6.24 presents the project support scores of all alternatives.

Table 6.24 Project support scores for all alternatives of the bypass project

\begin{tabular}{|c|c|c|c|c|c|}
\hline \multicolumn{7}{|c|}{ Alternative } \\
\hline A & B & C & D & E & F \\
\hline 2 & 2 & 2 & 2 & 2 & 2 \\
\hline
\end{tabular}

\section{Project selection}

The main purpose of the project selection model is to calculate a weighted evaluation score for each alternative based on the original scores of various attributes. Subsequently the competing alternatives can be compared in order to choose the most suitable one among them. Thus, one should keep in mind that this project has 3 sub-projects comprising of 3 comparisons, namely $A$ and $B, C$ and $D, E$ and $F$. The results at the end of the selection model for this project will therefore provide 3 potential routes from the 3 comparisons of the bypass project.

The project selection model follows these steps:

I) Construct a decision-making matrix based on the previous results of the evaluation model (economic, social, environmental, project support). 
2) Normalise the scores of all attributes using the formula (5.5) for benefit attributes and formula (5.6) for the cost attribute and then multiply the results by 100 . The benefit attributes include social $\left(C_{2}\right)$, environmental $\left(C_{3}\right)$ and project support $\left(C_{4}\right)$, and the cost attribute is economic $\left(C_{1}\right)$, where an alternative with a lower cost is more effective than a higher cost.

The original and normalised scores in the decision-making matrix are shown in Table 6.25.

Table 6.25 MADM matrix and the normalised scores (NS) of all alternatives for the bypass project

\begin{tabular}{|c|c|c|c|c|c|c|c|c|}
\hline \multirow{2}{*}{ Alternative } & \multicolumn{2}{|c|}{$\boldsymbol{C}_{\mathbf{1}}$} & \multicolumn{2}{c|}{$\boldsymbol{C}_{\mathbf{2}}$} & \multicolumn{2}{c|}{$\boldsymbol{C}_{3}$} & \multicolumn{2}{c|}{$\boldsymbol{C}_{4}$} \\
\cline { 2 - 9 } & $\begin{array}{c}\text { CEA } \\
\text { (million } \\
\text { THB) }\end{array}$ & NS* & $\begin{array}{c}\text { Social } \\
\text { score }\end{array}$ & NS* & $\begin{array}{c}\text { Environmental } \\
\text { impact }\end{array}$ & NS* & $\begin{array}{c}\text { Support } \\
\text { degree }\end{array}$ & NS* \\
\hline A & 22.95 & 93.35 & 2.14 & 100 & 1.71 & 100 & 2 & 100 \\
\hline B & 21.42 & 100 & 2.14 & 100 & 1.26 & 73.33 & 2 & 100 \\
\hline C & 31.46 & 100 & 2.69 & 93.07 & 2.00 & 100 & 2 & 100 \\
\hline D & 33.33 & 94.38 & 2.89 & 100 & 1.00 & 50 & 2 & 100 \\
\hline E & 31.93 & 100 & 2.27 & 98.05 & 1.34 & 67.14 & 2 & 100 \\
\hline F & 41.48 & 76.99 & 2.31 & 100 & 2.00 & 100 & 2 & 100 \\
\hline
\end{tabular}

*NS = Normalised score

3) The importance weights of all attributes are assigned below by the project analyst of the DoH which represent the attribute weight of economic, social, environmental and project support respectively. $W=[0.25,0.35,0.3,0.1]=1$

4) Calculate the evaluation score for each alternative using the formula (5.7) of the SAW model. Based on the formula, the normalised score (NS) of each attribute is multiplied by the importance weight of that attribute. Subsequently the results of weighted attributes scores are combined to reach the final weighted evaluation score of an alternative. The final weighted scores are shown in Table 6.26.

5) The alternatives are ranked from the highest to lowest scores based on the final weighted scores shown in last column of Table 6.26. 
Table 6.26 Evaluation scores for all alternatives of the bypass project

\begin{tabular}{|c|c|c|c|c|c|c|}
\hline \multirow{2}{*}{ Alternative } & \multicolumn{4}{|c|}{ Weighted attribute scores } & \multirow{2}{*}{$\begin{array}{c}\text { Final } \\
\text { weighted } \\
\text { scores }\end{array}$} & \multirow[t]{2}{*}{ Rank } \\
\hline & $C_{1}$ & $C_{2}$ & $C_{3}$ & $C_{4}$ & & \\
\hline$\overline{\mathbf{A}}$ & 23.34 & $\overline{35}$ & 30 & 10 & 98.34 & $\mathrm{I}$ \\
\hline $\mathbf{B}$ & 25 & 35 & 22 & 10 & 92.00 & 2 \\
\hline $\bar{C}$ & 25 & 32.57 & 30 & 10 & 97.57 & $\mathrm{I}$ \\
\hline $\mathbf{D}$ & 23.60 & 35 & 15 & 10 & 83.60 & 2 \\
\hline $\bar{E}$ & 25 & 34.32 & 20.14 & 10 & 89.46 & 2 \\
\hline $\mathbf{F}$ & 19.25 & 35 & 30 & 10 & 94.25 & $\mathrm{I}$ \\
\hline
\end{tabular}

After following the entire methodology, it finally provides the evaluation result of this project, which includes the final evaluation scores of all competing alternatives. Based on the result, alternative $A, C$ and $F$ have the highest scores compared to their competing alternatives.

\subsubsection{Discussion}

The application of the IDM to this project serves to demonstrate how the proposed IDM and its methodology are applied for appraising a public investment project on a local scale. Overall, the evaluation and selection process for this project can properly follow the structured methodology of the IDM, which starts at the evaluation part and culminates in the selection phase. The analysis is limited by the fact that it uses original information for measuring the project impact on economic, social, environmental and project support aspects.

The original information was actually collected for the different attributes (engineering, economic, environmental) that did not consider the social and project support aspects of the project, as it is proposed in the IDM, the most important aspects for public investment project evaluation and selection. On the other hand, the concepts of the IDM do not include the engineering aspect in the evaluation stage, as was done in the original assessment. The reason for that can be explained based on the logical grounds for a construction project. Since it is obvious that the engineering part is a very important aspect for a decision on any construction project, it is therefore believed that the full technical engineering aspect of all alternatives was carefully assessed at an early stage of the decision-making process. If an alternative does not meet the standard engineering specifications, such as technical complication; reasonable use of materials and resources, it will be rejected immediately. Based on these grounds and practical evidence, it is assumed that all competing alternatives that need to 
be evaluated meet the technical feasibility requirements, which is why the evaluation should focus on assessing the effectiveness and performances of the construction, rather than repeating the engineering part. Performance from an engineering point of view is reflected in the promising benefits of each alternative, which are provided to satisfy the project objectives. To this end, even though the IDM does not literally include an engineering aspect, the expected benefits resulting from the engineering specifications are included as part of the economic assessment, which is described in the following.

The economic impact of this project is measured using CEA instead of NPV, as suggested in the methodology of the IDM. The application shows that this alternative method is especially appropriate for projects at the local level, where there will often not be enough information available to adequately perform an NPV. The CEA results are also presented in absolute monetary terms, just as for the NPV, but its purpose is to compare monetary costs against the qualitative benefits of a project, which is a more sensible and rational approach towards making a decision than the original assessment, in which only costs are compared. The calculation of CEA, as discussed earlier, involves costs and some part of the engineering point of view in terms of project efficiency to represent benefits. This means that the engineering attribute from the current assessment is not ignored but is rather partially combined in the economic aspect of the IDM by the use of CEA.

The application of the methodology also shows that the IDM is adaptable to local projects. The use of population composition based on income level in the social model can divide people in the small affected area into different groups and prioritise them accordingly. Thus, even in a small local area, an impact that is distributed to society in varying degrees can be identified. The proposed social rating scale is also flexible enough to be used in this case. If the impact difference between two integers is too big, decimal numbers or median values can be assigned to indicate a smaller impact difference level. Furthermore, the use of the proposed rating scale does not change the meaningful level of the impact, especially as presented in the environmental assessment. The different environmental issues from the current assessment are summarised and mapped into a single matrix along with the proposed scale. The results of the environmental assessment between the use of the detailed scale and the proposed simple scale in the IDM are not different. Alternatives that provide less negative impact on many environmental issues still ultimately have higher total environmental scores. Stakeholder and local community participation in 
the project is identified by measuring their support level and consequently including stakeholder participation in the project evaluation and selection process. As a result of the project support model based on the original information, all alternatives produced the same performance score for this attribute.

The final evaluation scores of all alternatives are calculated in the selection model on the basis of a MADM/MCDM method (SAW model). The proposed method is appropriate for aggregating those scores into one single score. It is also compatible with various attributes expressed in different units and offers project analysts and decision-maker the ability to indicate their preferences through a weighting system. All attribute scores are weighted and assembled in order to present an overall evaluation score of each alternative. The comparisons include 3 pairs of competing alternatives and the highest one of each pair is the first to be selected. The three comparisons and the results include:

- $\quad$ Northern part ( $A$ against $B$ ): Alternative $A$ obtains the highest score due to its high scores on environmental and social attributes.

- Eastern part ( $C$ against $D)$ : Alternative $C$ obtains the highest score due to its high scores on economic and environmental attributes.

- Southern part ( $E$ against $F$ ): Alternative $F$ obtains the highest score due to its high scores on environmental and social attributes.

Given the final results, the potential alternatives for the bypass road compared between the current assessment and the new model (IDM) remain the same, namely alternative $A, C$ and $F$. The fact that the original assessment and the IDM led to the same results is a coincidence, and this does not always happen in every case. Different results could arise due to the consideration of other aspects, such as social and project support, as well as different ways of evaluating the economic aspect. Moreover, the project support attribute in this case provides the same scores for all alternatives and thus this attribute, unfortunately, does not affect the final evaluation scores of this project.

To this end, the IDM and its methodology are appropriate for public investment projects in a local area. The IDM includes more important aspects required for a public investment project decision, namely economic, social, environmental and project support, than the original assessment. The engineering point of view, which was considered in the original assessment, is also included as part of the economic assessment of the IDM. The IDM and its components are also flexible 
enough to be applied to a local project. The flexibility indicates the possibility to replace the existing method with other alternative methods or to add more variables to the model, as demonstrated in the economic and environmental model. Moreover, the use of the proposed simple scale also makes the detailed assessment simpler and it can be used for any qualitative assessment. The selection model (SAW model) of the IDM can deal with different units and offers the decision-maker the chance to assign weighted preferences. The IDM may not always produce different results, but it is obvious that the new results provide more insights to decision-makers with regard to all important aspects which are influenced by a project, which, consequently, makes an investment decision more explicit and transparent.

\subsection{CONCLUSION}

The application of the proposed IDM to the two real project cases in Thailand in this chapter serves to validate the IDM and its methodology and to test its effectiveness in terms of adaptability and its flexibility, allowing it to be applied to any public investment project. The project cases demonstrate the appropriateness of the core principle underlying the IDM, which also includes, in addition to economic assessment, social, environmental and project support points of view. The case studies have also shown that the IDM can be adapted to any impact scale/size of public investment projects in order to make the original assessment more explicit and transparent.

The first case, involving 'the Irrigation Development Project in Yom River Basin', has shown that the IDM is appropriate for evaluating projects with a regional impact scale. The use of suggested NPV makes the economic assessment more consistent than the current use of IRR. The proposed qualitative scale in the IDM also enhances the descriptive results of the IEE and makes them more explicit.

The second case study, applying the IDM on 'the Bypass Road Project in Chachoengsao town', has also proved the adaptability of the methodology for a project at local level. Original information can be used, and the evaluation and selection of the project can be carried out by means of the methodology. Moreover, the flexibility of the IDM was highlighted well in this case, as was demonstrated by the economic model. When the local organisation does not have sufficient information to assess the economic benefit of the project, the 
CEA, which requires less information, can be used to measure its cost effectiveness.

Both cases have shown that the original assessments lack important criteria/attributes and information required for evaluating a public investment projects, namely social and project support attributes. The IDM does include these attributes. External data obtained from a trustworthy government agency is used to indicate the social variables of the projects. The results of the social assessment of both projects have indicated the usefulness of the use of population compositions based on income levels and the social effects of the projects distributed to different groups of population, which are not addressed in the original assessments. Moreover, the existing information of both cases has no assessment about stakeholders and local communities supporting the projects. They only provide the comments relevant people and communities which is organised by the project agencies through general public participation, and those results were not included into the decision. The project support attribute proposed in the IDM can only apply based on the current assessment and existing information, which is why this attribute makes no significant contribution the final evaluation scores of both assessments, due to the fact that all alternatives have identical support scores. The scores on the project support attribute will be different among competing alternatives when the project organisation and authorities realise the importance of this attribute in the decision and organise a discreet participation and cooperation method in order to measure its result. The practical implications of this issue will be addressed in chapter 8.

The application also shows that the MADM/MCDM method can deal with different units. Alternatives can easily be prioritised based on their final evaluation scores. The final evaluation scores of all alternatives can be traced to their importance on evaluation attributes, which are related to project objectives and goals. The new decision model does not always offer different results, but supplies a decision-maker with more information to make an investment decision explicit and transparent, especially when this investment concerns society and the environment. Decision-makers and project organisers can use the results to support their investment idea and project proposals in practice.

Further examination of the IDM will revolve around testing the result in the event that the project support attribute is one of the most important concerns, 
as the methodology proposes. The testing will use different project support scores for all competing alternatives and the investigation will focus on whether they affect the final scores and ranking orders. Moreover, the robustness of the evaluation results will be tested by means of a sensitivity analysis on weights to investigate the change in ranking orders of alternatives. 
$140 \mid$ 
Chapter 


\section{ASSESSMENT AND TESTING}

The proposed integrated decision model (IDM) and its methodology have been developed with the intention to support the project evaluation and selection process and, as a result, to improve the quality of evaluation and decisionmaking by the government at the project level. This section is presented to ensure that the IDM and its methodology are practicable and effective and can be applied in the real world.

With this aim in mind, two alternative testing procedures are used for this task. The first one was carried out at the early stage of the IDM development (the conceptual phase) to receive user impression and feedback. The conceptual IDM was presented to a group of public investment project experts in a number of organisations in Thailand for assessment and comments. The assessment results are shown in section 7.1 and they were used to improve the development of IDM before applying it to the existing project cases. Section 7.2 presents the second part of the testing, based on a sensitivity analysis. The sensitivity analysis is suggested to be included as part of the methodology for assessing the robustness of the evaluation and selection result derived from the decision model.

\section{I EXPERTS' ASSESSMENT}

This section describes the assessment of the concept of IDM and its working provided by the various analysts and experts, who will be its main users. The contact with the analysts and experts was facilitated by the research funder, Hydro and Agro Informatics Institute (HAll), and the participants in this assessment were selected based on their experience related to project evaluation and decision-making in different fields. The assessment was also intended to make sure that applying the various steps within the proposed IDM is feasible and not too complicated for practical purposes.

Initially the conceptual methodology was presented and explained by the researcher to several panels of experts at relevant local and central agencies in Thailand. The number of experts who attended the panels was 40 . Their comments and questions during the presentation were discussed with the researcher during the panels. Following the meetings, a questionnaire was sent by email to each participant to request feedback on his or her assessment of the methodology. They were requested to provide their opinion of the 
methodology by answering questions using a 4-point scale ranging from 'disagree' to 'strongly agree'. 30 of the participants responded to the request and provided the information. The assessment included three aspects of the proposed methodology, namely;

(I) Ease of use: to assess whether the user understands how the methodology works with respect to the evaluation and selection.

(2) Appropriateness of factors used: This is to assess whether the user agrees with the factors and variables used in the evaluation and whether they cover all important aspects required.

(3) Adaptability and flexibility: to assess the adaptability and flexibility of the methodology and the decision model for use in different organisations and for different types of projects.

The general results of the assessment of the methodology by the experts are shown in Figure 7.I.

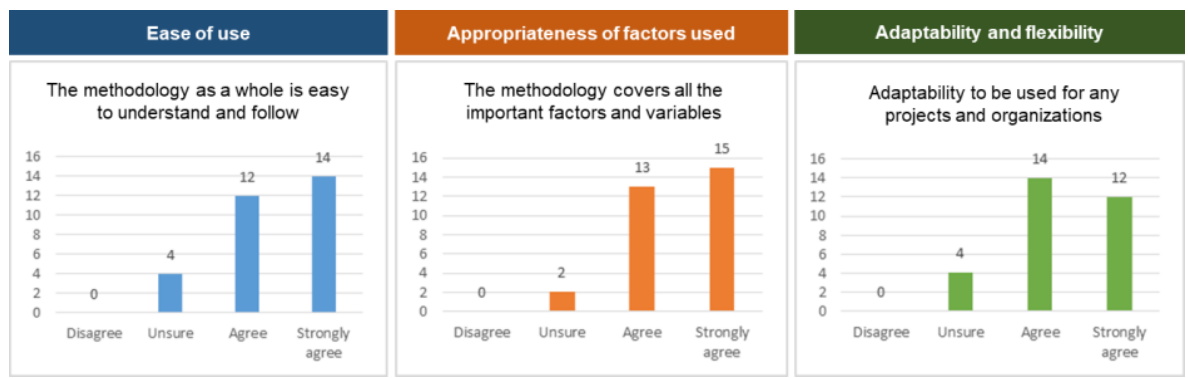

Figure 7.I The assessment results of the conceptual methodology and the decision model

The results shown in Figure 7.1 demonstrate that $87 \%$ of the experts agree that the methodology and the decision model are easy to understand and follow. The other $13 \%$ were unsure and provided comments related to their responses. The overall comments were related to the calculation used in the different models, which were unfamiliar to them. The proposed NPV calculation for measuring the economic aspect, for instance, has rarely been used and is unknown to various experts in local agencies. Their suggestion was to supplement the methodology with an example of the calculations using this technique. This indicates that, even though these experts are working at the same level in the project evaluation, they have different backgrounds in and experience with using common evaluation methods. In some cases, local 
agencies deal with small-scale projects of which the project costs are known, but the benefits are subjective and difficult to estimate in monetary terms. Instead of NPV, the methodology will allow the user to adopt a simple benefit/cost ratio to compare the economic effectiveness of the different alternatives. This will be done by using only the relative costs of the alternatives, assuming that all alternatives to the intended project will produce similar benefits.

The results also show that $93 \%$ of the experts agree that the methodology and the decision model cover all the important factors and variables required for evaluating a public investment project. Only $7 \%$ of them were unsure whether all factors used are comprehensive or appropriate for all types of projects. They recommended demonstrating how the methodology works using real project cases to ensure that the factors used are appropriate for and adaptable to all project contexts.

In response to the adaptability and flexibility of the methodology, nearly $87 \%$ of the experts responded positively and indicated that the methodology and the decision model are adaptable and flexible enough to be used for evaluating and selecting projects in their organisations. The remaining $13 \%$ of the experts were unsure whether the model could be applied directly in local agencies. The main concerns revolved around about users' capability at local agencies and how to obtain the input data required for the model. Evaluators in local agencies normally rely on their intuitions and judgment in the project evaluation and selection procedure and hence may require some training on how to use some of the quantitative techniques proposed in the methodology. Analysis of the comments also indicated that some of the people involved do not have much experience in translating information and subjective judgements into a measurable indicator.

Given the assessment results, their comments and suggestions were addressed in the development phase by demonstrating the methodology and the decision model with real project cases, as presented in Chapter 6. The application in Chapter 6 shows the use of several techniques proposed in the model, as well as presenting cases on how to use qualitative information and transform it into a measurable form. The concerning issue about the difficulty to use NPV as an economic measure for local projects has been examined and it is possible to substitute the NPV with an alternative economic mode, namely CEA (costeffectiveness analysis), as shown in the bypass project. To this end, the overall 
results of the assessment of the methodology by experts, as well as the application to the real project cases, indicate that the methodology and the decision model are useful and practical for use in the evaluation and selection of public investment projects in Thailand. The decision model that makes up part of the methodology is also adaptable and flexible enough to be applied for any type of public investment projects. For further substantial practices, some specific training might be required to enhance users' capability, especially when working with local and non-technical project analysts and evaluators.

\subsection{SENSITIVITY ANALYSIS}

Testing is an essential part of any development process. It is required to ensure whether the developed model and its results meet the expected objectives and can be confidently used for the final stage. In the decision-making context, one of the most important issues is that problems are usually measured subjectively by decision-makers and that the data they use is changeable. The use of sensitivity analyses can be very useful and it is suggested that these analyses be conducted as part of the decision analysis for assessing errors of the results in response to changes in the data used (Massam, 1999).

Sensitivity analysis is an analytical method for assessing the responsiveness of the results to changes in the data used. The results it produces are indicators of the elements that have more significant effects on the choice of project alternatives. In the proposed methodology, the choices depend very much on criteria/attribute weights assigned by decision-makers or project analysts. However, the inconsistency problem associated with subjective weighting has been addressed in many studies, reflecting the inherent difficulty of assigning reliable subjective weights (Deng, et al., 2000). The sensitivity analysis in the proposed IDM is performed to demonstrate whether small changes to weights will change the final ranking of alternatives. The test involves changing the weight of one criterion at a time while fixing the weights of other attributes (Memariani, et al., 2009).

Additionally, as shown in the evaluation scores and weighted scores of the applications of two project cases in Chapter 6, the scores of Project Support attribute for all alternatives are identical. This suggests that this attribute has no significant contribution to the final evaluation scores of all alternatives. In fact, when the attribute scores of all alternatives are the same, this attribute and its scores can be ignored. Nevertheless, according to the concept underlying the 
IDM, one of the highlights of this approach is that it promotes stakeholder and local communities' involvement and collaboration through the Project Support attribute and demonstrates how this attribute influences the final result. With this in mind, the sensitivity analysis to test the result of this project case comprises two parts:

- The original weights and original performance attribute scores are used to run the sensitivity analysis in order to investigate how sensitive the final ranks would change if the weights of attributes were to be changed.

- The second part involves demonstrating the importance of the Project Support attribute, in terms of how it affects the final score. This is done by assuming that the project support levels of all alternatives are different and thus the performance scores of the project support attribute for all alternatives are accordingly adjusted. When all alternatives have different project support scores, the final weighted scores will be changed. The adjusted final scores will be tested again with the sensitivity analysis to investigate the change in the final ranks.

In this section, the steps of the sensitivity analysis on weights for the SAW technique based on the methodology by Memariani et al. (2009) are first described in section 7.2.I. Later, the evaluation results based on the two project cases will be tested and analysed in accordance with these steps.

\subsection{Sensitivity analysis methodology}

Step I: Prepare the original attribute weights. In this case, the attributes are denoted as $C_{1}, C_{2}, C_{3}, C_{4}$ which represent economic, social, environmental, and project support respectively.

The vector for attribute weights is

$W^{t}=\left(w_{1}, w_{2}, w_{3}, w_{4}\right)$ in which weights are normalised and sum to $\mathrm{I}$.

Step 2: Establish the test cases for each attribute. In this case, the weight of each attribute is changed by slightly increasing and decreasing the original weight. When the weight of one attribute is changed, the other attributes weights should be changed proportionally. The equations used to calculate the new weights are as follows: 
If the weight of attribute $C^{t h}$ changes from $w_{p}$ to $w_{p}^{\prime}$ as:

$$
w_{p}^{\prime}=w_{p}+\Delta_{p}
$$

Then the weight of other attributes is calculated as:

$$
\begin{aligned}
& w_{j}^{\prime}=\frac{1-w_{p}-\Delta_{p}}{1-w_{p}} \cdot w_{j} \quad=\frac{1-w^{\prime} p}{1-w_{p}} \cdot w_{j} \\
& ; j=1,2, \ldots, k \text { and } j \neq p
\end{aligned}
$$

The sum of new weights of attributes is I, as:

$$
\sum_{\substack{j=1 \\ j \neq p}}^{k} w_{j}^{\prime}+w_{p}^{\prime}=1
$$

Step 3: Run sensitivity analysis and calculate the new final score for all alternatives based on adjusted weights.

The new final score of alternative $A_{i}$ is $P_{i}^{\prime}$, where

$$
P_{i}^{\prime}=\sum_{j=1}^{k} w_{j}^{\prime} \cdot r_{i j} \quad ; i=1,2, \ldots, m
$$

and $r_{i j}$ is a performance score of alternative $i$ on attribute $j$.

Step 4: Analyse the changing final scores that result in changes in original ranking of alternatives.

\subsubsection{Testing case I: An Irrigation Development Project in Yom River Basin}

The sensitivity analysis to test the result of this project case comprises two parts. One uses the original weights and original performance attribute scores to run the sensitivity analysis in order to investigate how sensitive the final ranks would be if the weights of attributes were to be changed. The second part involves demonstrating the importance of the project support attribute, in terms of how it effects the final score. This will be done by adjusting the performance 
score of the project support attribute for all alternatives. When all alternatives have different project support scores, the final weighted scores will be changed. The changed final scores will be tested again with the sensitivity analysis.

Step I: The original importance weights of all attributes are assigned below and represent the attribute weights of economic, social, environmental and project support, respectively.

$$
W=[0.2,0.3,0.3,0.2]=1
$$

Step 2: Establish the test cases for each attribute. In this case, the weight of each attribute is changed by increasing and decreasing the original weight by $10 \%, 20 \%, 30 \%, 40 \%$ and $50 \%$, respectively. This means that one weight will be increased and decreased slightly while the weights of other attributes are maintained proportionally. This process will be repeated for all four weights. The new weights for all attributes $\left(C_{1}, C_{2}, C_{3}, C_{4}\right)$ based on the sensitivity analysis method when each attribute weight is changed are shown in Table 7.I - 7.4.

Table 7.I New weights based on the weight changed for the Economic attribute (irrigation project)

\begin{tabular}{|c|c|c|c|c|c|c|c|c|c|c|c|}
\hline & $-50 \%$ & $-40 \%$ & $-30 \%$ & $-20 \%$ & $-10 \%$ & $0 \%$ & $+10 \%$ & $+20 \%$ & $+30 \%$ & $+40 \%$ & $+50 \%$ \\
\hline$C_{1}$ & 0.10 & 0.12 & 0.14 & 0.16 & 0.18 & 0.2 & 0.22 & 0.24 & 0.26 & 0.28 & 0.30 \\
\hline$C_{2}$ & 0.338 & 0.33 & 0.323 & 0.315 & 0.308 & 0.3 & 0.293 & 0.285 & 0.278 & 0.270 & 0.263 \\
\hline$C_{3}$ & 0.338 & 0.33 & 0.323 & 0.315 & 0.308 & 0.3 & 0.293 & 0.285 & 0.278 & 0.270 & 0.263 \\
\hline$C_{4}$ & 0.225 & 0.22 & 0.215 & 0.21 & 0.205 & 0.2 & 0.195 & 0.19 & 0.185 & 0.18 & 0.175 \\
\hline Sum & $\mathrm{I}$ & $\mathrm{I}$ & $\mathrm{I}$ & $\mathrm{I}$ & $\mathrm{I}$ & $\mathrm{I}$ & $\mathrm{I}$ & $\mathrm{I}$ & $\mathrm{I}$ & $\mathrm{I}$ & $\mathrm{I}$ \\
\hline
\end{tabular}

Table 7.2 New weights based on the weight changed for the Social attribute (irrigation project)

\begin{tabular}{|c|c|c|c|c|c|c|c|c|c|c|c|}
\hline & $-50 \%$ & $-40 \%$ & $-30 \%$ & $-20 \%$ & $-10 \%$ & $0 \%$ & $+10 \%$ & $+20 \%$ & $+30 \%$ & $+40 \%$ & $+50 \%$ \\
\hline$C_{1}$ & 0.243 & 0.234 & 0.226 & 0.217 & 0.209 & 0.2 & 0.191 & 0.183 & 0.174 & 0.166 & 0.157 \\
\hline$C_{2}$ & 0.15 & 0.18 & 0.21 & 0.24 & 0.27 & 0.3 & 0.33 & 0.36 & 0.39 & 0.42 & 0.45 \\
\hline$C_{3}$ & 0.364 & 0.351 & 0.339 & 0.326 & 0.313 & 0.3 & 0.287 & 0.274 & 0.261 & 0.249 & 0.236 \\
\hline$C_{4}$ & 0.243 & 0.234 & 0.226 & 0.217 & 0.209 & 0.2 & 0.191 & 0.183 & 0.174 & 0.166 & 0.157 \\
\hline Sum & $\mathrm{I}$ & $\mathrm{I}$ & $\mathrm{I}$ & $\mathrm{I}$ & $\mathrm{I}$ & $\mathrm{I}$ & $\mathrm{I}$ & $\mathrm{I}$ & $\mathrm{I}$ & $\mathrm{I}$ & $\mathrm{I}$ \\
\hline
\end{tabular}


Table 7.3 New weights based on the weight changed for the Environmental attribute (irrigation project)

\begin{tabular}{|c|c|c|c|c|c|c|c|c|c|c|c|}
\hline & $-50 \%$ & $-40 \%$ & $-30 \%$ & $-20 \%$ & $-10 \%$ & $0 \%$ & $+10 \%$ & $+20 \%$ & $+30 \%$ & $+40 \%$ & $+50 \%$ \\
\hline$C_{1}$ & 0.243 & 0.234 & 0.226 & 0.217 & 0.209 & 0.2 & 0.191 & 0.183 & 0.174 & 0.166 & 0.157 \\
\hline$C_{2}$ & 0.364 & $0.35 \mathrm{I}$ & 0.339 & 0.326 & 0.313 & 0.3 & 0.287 & 0.274 & $0.26 \mathrm{I}$ & 0.249 & 0.236 \\
\hline$C_{3}$ & 0.15 & 0.18 & 0.21 & 0.24 & 0.27 & 0.3 & 0.33 & 0.36 & 0.39 & 0.42 & 0.45 \\
\hline$C_{4}$ & 0.243 & 0.234 & 0.226 & 0.217 & 0.209 & 0.2 & 0.191 & 0.183 & 0.174 & 0.166 & 0.157 \\
\hline Sum & $\mathrm{I}$ & $\mathrm{I}$ & $\mathrm{I}$ & $\mathrm{I}$ & $\mathrm{I}$ & $\mathrm{I}$ & $\mathrm{I}$ & $\mathrm{I}$ & $\mathrm{I}$ & $\mathrm{I}$ & $\mathrm{I}$ \\
\hline
\end{tabular}

Table 7.4 New weights based on the weight changed for the Project

Support attribute (irrigation project)

\begin{tabular}{|c|c|c|c|c|c|c|c|c|c|c|c|}
\hline & $-50 \%$ & $-40 \%$ & $-30 \%$ & $-20 \%$ & $-10 \%$ & $0 \%$ & $+10 \%$ & $+20 \%$ & $+30 \%$ & $+40 \%$ & $+50 \%$ \\
\hline$C_{1}$ & 0.225 & 0.22 & 0.215 & 0.21 & 0.205 & 0.2 & 0.195 & 0.19 & 0.185 & 0.18 & 0.175 \\
\hline$C_{2}$ & 0.338 & 0.33 & 0.323 & 0.315 & 0.308 & 0.3 & 0.293 & 0.285 & 0.278 & 0.270 & 0.263 \\
\hline$C_{3}$ & 0.338 & 0.33 & 0.323 & 0.315 & 0.308 & 0.3 & 0.293 & 0.285 & 0.278 & 0.270 & 0.263 \\
\hline$C_{4}$ & 0.10 & 0.12 & 0.14 & 0.16 & 0.18 & 0.2 & 0.22 & 0.24 & 0.26 & 0.28 & 0.30 \\
\hline Sum & $\mathrm{I}$ & $\mathrm{I}$ & $\mathrm{I}$ & $\mathrm{I}$ & $\mathrm{I}$ & $\mathrm{I}$ & $\mathrm{I}$ & $\mathrm{I}$ & $\mathrm{I}$ & $\mathrm{I}$ & $\mathrm{I}$ \\
\hline
\end{tabular}

The calculation results on weights in Table 7.I - 7.4 show that changing the weight of one attribute affects the weight of other attributes and consequently generates a new weight vector. For example, increasing economic weight by $10 \%$ leads to a new weight vector: [0.22, 0.293, 0.293, 0.195].

Step 3: Run sensitivity analysis and calculate the new final score for all alternatives based on all sets of new weights vectors in the previous step.

Table 7.5 - 7.8 present the original (at $0 \%$ ) and new final weighted scores for all alternatives, which are calculated with regard to the attributes weights changed in the previous step.

Table 7.5 The original and new weighted scores based on the weights changed in Economic attribute (irrigation project)

\begin{tabular}{|c|c|c|c|c|c|c|c|c|c|c|c|}
\hline $\boldsymbol{C}_{\mathbf{1}}$ & $-50 \%$ & $-40 \%$ & $-30 \%$ & $-20 \%$ & $-10 \%$ & $0 \%$ & $+10 \%$ & $+20 \%$ & $+30 \%$ & $+40 \%$ & $+50 \%$ \\
\cline { 1 - 10 } Alt & & & & & & & & & & & \\
\hline A & 81.80 & 82.21 & 82.61 & 83.02 & 83.42 & 83.82 & 84.23 & 84.63 & 85.04 & 85.44 & 85.85 \\
\hline B & 79.15 & 77.73 & 76.31 & 74.90 & 73.48 & 72.06 & 70.64 & 69.22 & 67.80 & 66.38 & 64.96 \\
\hline C & 94.47 & 93.82 & 93.16 & 92.50 & 91.85 & 91.19 & 90.54 & 89.88 & 89.22 & 88.57 & 87.91 \\
\hline D & 80.71 & 79.23 & 77.75 & 76.27 & 74.78 & 73.30 & 71.82 & 70.34 & 68.85 & 67.37 & 65.89 \\
\hline
\end{tabular}


Table 7.6 The original and new weighted scores based on the weights changed for the Social attribute (irrigation project)

\begin{tabular}{|c|c|c|c|c|c|c|c|c|c|c|c|}
\hline$C_{2}$ & $-50 \%$ & $-40 \%$ & $-30 \%$ & $-20 \%$ & $-10 \%$ & $0 \%$ & $+10 \%$ & $+20 \%$ & $+30 \%$ & $+40 \%$ & $+50 \%$ \\
\cline { 1 - 10 } Alt & & & & & & & & & & & \\
\hline A & 89.34 & 88.24 & 87.13 & 86.03 & 84.93 & 83.82 & 82.72 & 81.62 & 80.51 & 79.41 & 78.31 \\
\hline B & 73.93 & 73.55 & 73.18 & 72.81 & 72.43 & 72.06 & 71.68 & 71.31 & 70.93 & 70.56 & 70.19 \\
\hline C & 89.30 & 89.68 & 90.06 & 90.44 & 90.81 & 91.19 & 91.57 & 91.95 & 92.32 & 92.70 & 93.08 \\
\hline D & 73.08 & 73.12 & 73.17 & 73.21 & 73.26 & 73.30 & 73.35 & 73.39 & 73.43 & 73.48 & 73.52 \\
\hline
\end{tabular}

Table 7.7 The original and new weighted scores based on the weights changed for the Environmental attribute (irrigation project)

\begin{tabular}{|c|c|c|c|c|c|c|c|c|c|c|c|}
\hline $\boldsymbol{C}_{\mathbf{3}}$ & $-50 \%$ & $-40 \%$ & $-30 \%$ & $-20 \%$ & $-10 \%$ & $0 \%$ & $+10 \%$ & $+20 \%$ & $+30 \%$ & $+40 \%$ & $+50 \%$ \\
\cline { 1 - 10 } Alt & & & & & & & & & & & \\
\hline A & 82.93 & 83.11 & 83.29 & 83.47 & 83.65 & 83.82 & 84.00 & 84.18 & 84.36 & 84.54 & 84.72 \\
\hline B & 66.07 & 67.27 & 68.46 & 69.66 & 70.86 & 72.06 & 73.25 & 74.45 & 75.65 & 76.85 & 78.04 \\
\hline C & 90.59 & 90.71 & 90.83 & 90.95 & 91.07 & 91.19 & 91.31 & 91.43 & 91.55 & 91.67 & 91.79 \\
\hline D & 68.87 & 69.75 & 70.64 & 71.53 & 72.41 & 73.30 & 74.19 & 75.08 & 75.96 & 76.85 & 77.74 \\
\hline
\end{tabular}

Table 7.8 The original and new weighted scores based on the weights changed for the Project support attribute (irrigation project)

\begin{tabular}{|c|c|c|c|c|c|c|c|c|c|c|c|}
\hline $\boldsymbol{C}_{\boldsymbol{4}}$ & $-50 \%$ & $-40 \%$ & $-30 \%$ & $-20 \%$ & $-10 \%$ & $0 \%$ & $+10 \%$ & $+20 \%$ & $+30 \%$ & $+40 \%$ & $+50 \%$ \\
\cline { 1 - 9 } Alt & & & & & & & & & & & \\
\hline A & 81.80 & 82.21 & 82.61 & 83.02 & 83.42 & 83.82 & 84.23 & 84.63 & 85.04 & 85.44 & 85.85 \\
\hline B & 68.56 & 69.26 & 69.96 & 70.66 & 71.36 & 72.06 & 72.76 & 73.45 & 74.15 & 74.85 & 75.55 \\
\hline C & 90.09 & 90.31 & 90.53 & 90.75 & 90.97 & 91.19 & 91.41 & 91.63 & 91.85 & 92.07 & 92.29 \\
\hline D & 69.96 & 70.63 & 71.30 & 71.97 & 72.63 & 73.30 & 73.97 & 74.64 & 75.30 & 75.97 & 76.64 \\
\hline
\end{tabular}

Based on Table $7.5-7.8$, the original final weighted scores for all alternatives are shown in the $0 \%$ column and the new final weighted scores are presented in other columns. For example, the original score of alternative $A$ is 83.82 and, according to the same example in the previous step, its new final weighted score with regard to the new weight vector [0.22, 0.293, 0.293, 0.195] (when economic weight increased $10 \%$ ) is 84.23 .

The overall results of the sensitivity analysis based on changing weights for all alternatives are presented in the graphs shown in Figure 7.2.

The sensitivity analysis presented in Figure 7.2 shows that some alternatives are sensitive to changes in some attribute weights, which results in changes in the final weighted scores and consequently the ranking of alternatives. Based on the original weight vector, alternative $C$ is the highest-ranking alternative. Second place belongs to alternative $A$, followed by alternative $D$ and $B$ respectively. 
The original ranks are: $C>A>D>B$

The following part of this section discusses the relations between alternatives and attributes and how the changed attribute weights affect the ranks of alternatives. The analysis is done first for each alternative and later the summary of the results will lead to the second part of the sensitivity analysis.

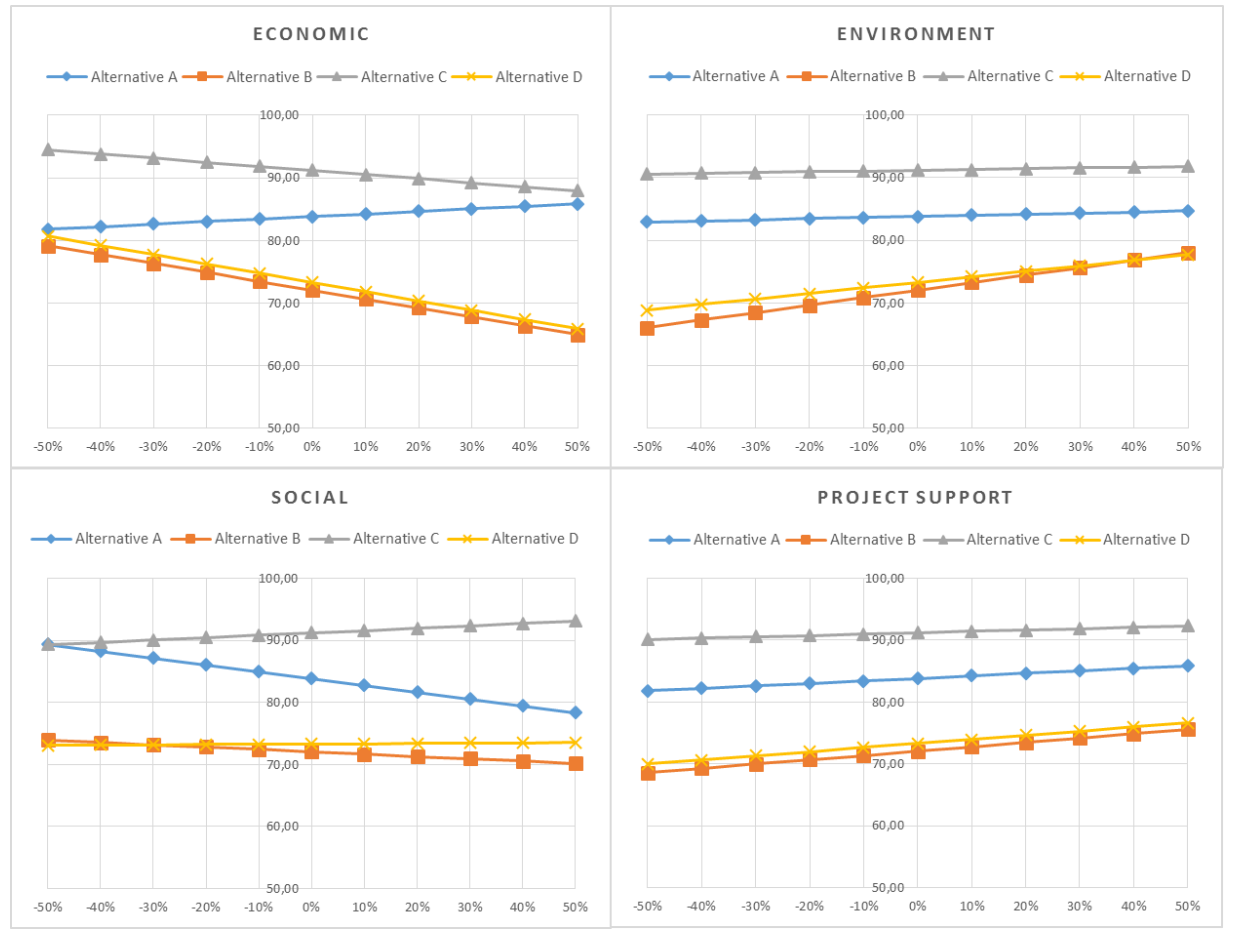

Figure 7.2 Changes in final scores for all alternatives based on changes in weights (irrigation project)

Overall results of the sensitivity analysis show that the ranks of alternatives are not changed dramatically when the attribute weights are adjusted. However, final scores are sensitive to changes to weights for some attributes, specifically the economic and social attributes. Alternative $A$ is sensitive to the changes in the social and economic weights. The ranks of alternatives change when the social weight is lowered by $-50 \%$, yielding $A>C>B>D$. As opposed to the social weight, increasing or decreasing the economic weight similarly affects the score of alternative $A$ but does not affect the original rank. These presented results are due to the extreme scores of alternative $A$ on the economic (the highest) and environmental (the lowest) attributes, compared to other alternatives. 
Alternative $B$ is highly sensitive to the changes to economic and environmental weights. Unlike alternative $A$, the score of $B$ decreases when giving a higher weight to the economic attribute, but the higher weight in the environmental attribute leads to an increase in B's score. This is due to its low score on the economic attribute and the highest score on the environmental attribute. The analysis shows that the rank of alternative $B$ can change if the weight of the environmental attribute is increased by more than $+40 \%$, yielding $C>A>B>$ $D$.

Alternative $C$ is also sensitive to the economic and social attributes. It is presented as the best alternative in the original rank due to its highest final score, but, as mentioned in the analysis of alternative $A$, if the decision-maker lowers the social attribute by $-50 \%$, alternative $C$ will have a lower score and will end up in second place. On the other hand, if the economic weight is lowered, the final score of $C$ increases further, at which point it will all other alternatives.

Alternative $D$ is highly sensitive to the economic and environmental attribute. Like alternative $B$, the score of $D$ dramatically rises when the economic weight is decreased and it almost reaches the level of alternative $A$ when economic weight is decreased by $-50 \%$. This is due to its lowest score on the economic attribute. Moreover, changing the environmental weight also noticeably affects the final score of $D$. In relation to alternative $B$, the higher weight in the environmental attribute leads to higher score for $D$. Although both alternative $B$ and $D$ seem to share the same trends in general, the environmental graph shows that alternative $B$ is more sensitive to weight changes in in environmental and it takes over the position of alternative $D$ when this weight is increased by more than $+40 \%$, as mentioned before.

For all alternatives, there are no significant changes in the final scores and ranks of alternatives related to the weight changed in project support attribute. The scores of all alternatives are changed accordingly, but are increased and decreased in the same trend, which is due to the fact that their project support scores are identical.

In fact, when the scores of all alternatives in an attribute are the same, we can omit that attribute and its scores. According to the core concept underlying the IDM and its methodology, however, a main highlight of this approach is that it promotes stakeholder involvement, local community participation and collaboration through the project support aspect and demonstrates how this 
attribute influences the evaluation result. With this in mind, the second analysis is therefore established assuming that the project support scores of alternatives are different. This must be done in the project support model by giving alternative $A$ and $B$ a score of 3 (strong support by stakeholders and the local community), which means they have a different project support score than the other alternatives $(C$ and $D)$. Accordingly, the final scores of the four alternatives are recalculated to examine the results, re-using all new weight vector sets generated previously. Figure 7.3 shows the sensitivity analysis based on the different project support scores of alternative $A$ and $D$.

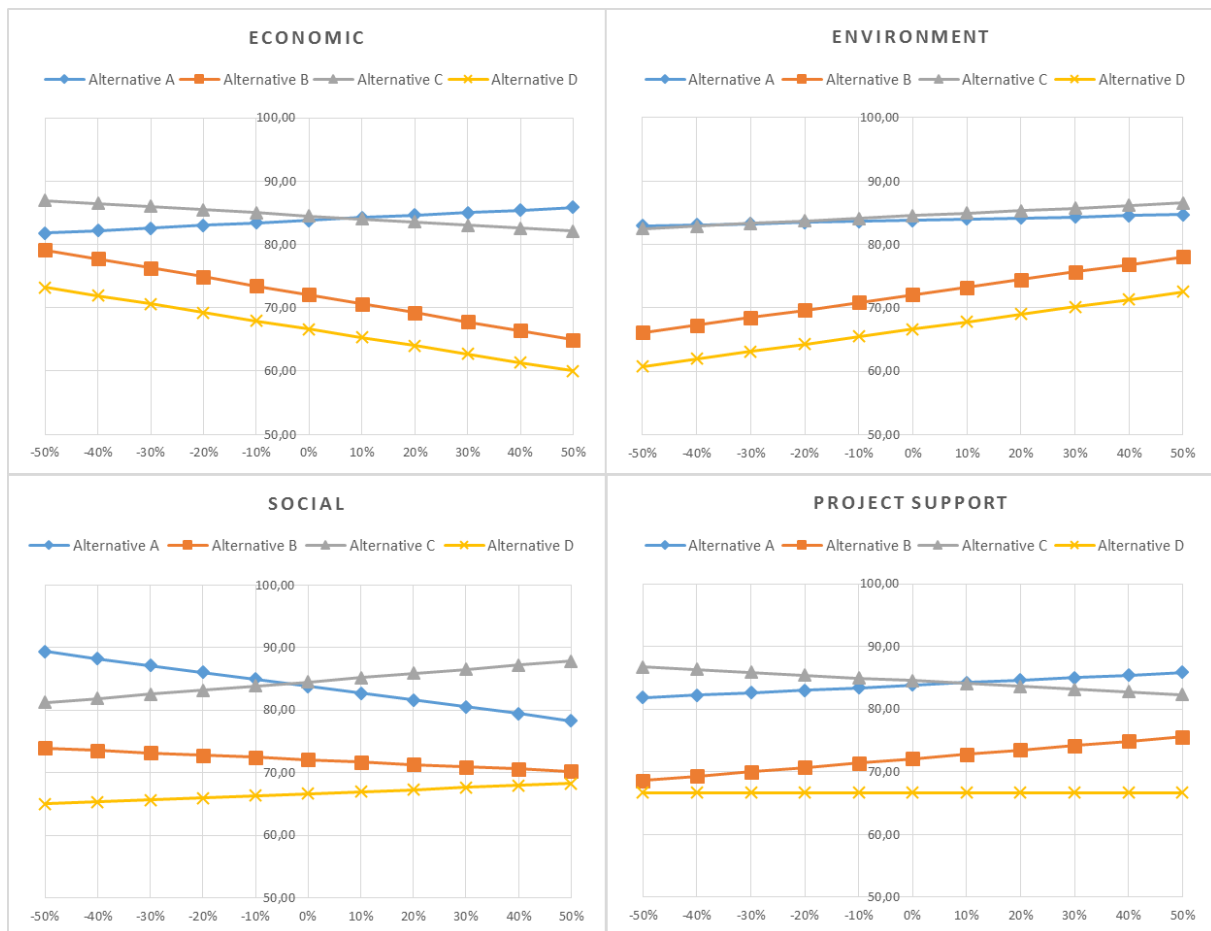

Figure 7.3 Sensitivity analysis based on adjusting the project support score of $A$ and $B$ (irrigation project)

Once the project support scores of some alternatives, in this case are $A$ and $B$, are different, the final evaluation result and the sensitivity analysis are adjusted. By comparing the results in Figure 7.2 and 7.3, it is shown that adjusting the project support score does not change the final scores of alternatives $A$ and $B$, but does negatively affect the final scores of alternative $C$ and $D$. The results also show that the first highest final score still belongs to alternative $C$ and that second place still falls to $A$, but the scores between these two alternatives are 
not significantly different. As a result of the similar scores, the ranking of alternatives is sensitively changed when the weight of any attribute is adjusted by only $10 \%$. As shown in Figure 7.3, for example, alternative $A$ will move to first place instead of $C$ when either the social weight is decreased by $10 \%$, or the economic weight is increased by $10 \%$, or the project support weight is increased by $10 \%$. On the other hand, the final scores of alternative $B$ and $D$ have a bigger difference and their ranks remain the same, regardless of changes to any of the attribute weights.

\subsubsection{Testing case 2: A Bypass Road Project in Chachoengsao Province}

The sensitivity analysis conducted to test the result of this project case is carried out in the same as for the previous case. It is comprised of two tests. One uses the original weights and original performance attribute scores to run the sensitivity analysis in order to investigate how sensitive the final ranks would be when the weights of attributes are changed. The second part involves demonstrating the importance of the project support attribute in terms of how it effects the final score. This will be done by adjusting the performance score of the project support attribute for all alternatives, so that they are different from the original scores. When all alternatives have different project support scores, the final weighted scores will change. The changes of final scores will be tested again by means of a sensitivity analysis.

Step I: The original importance weights of all attributes are shown below and represent the attribute weights of economic, social, environmental and project support respectively.

$W=[0.25,0.35,0.3,0.1]=1$

Step 2: Establish the test cases for each attribute. In this case, the weight of each attribute is changed by increasing and decreasing the original weight by $10 \%, 20 \%, 30 \%, 40 \%$ and $50 \%$ respectively. This means that one weight will be slightly increased and decreased while the other attributes maintain their proportional weights. This process is repeated for all four weights.

The new weights for all attributes $\left(C_{1}, C_{2}, C_{3}, C_{4}\right)$ based on the sensitivity analysis method when each attribute weight is changed are shown in Table 7.9 -7.12 . 
Table 7.9 New weights based on the weight changed for the Economic attribute (bypass road project)

\begin{tabular}{|c|c|c|c|c|c|c|c|c|c|c|c|}
\hline & $-50 \%$ & $-40 \%$ & $-30 \%$ & $-20 \%$ & $-10 \%$ & $0 \%$ & $+10 \%$ & $+20 \%$ & $+30 \%$ & $+40 \%$ & $+50 \%$ \\
\hline$C_{1}$ & 0.125 & 0.15 & 0.175 & 0.2 & 0.225 & 0.25 & 0.275 & 0.3 & 0.325 & 0.35 & 0.375 \\
\hline$C_{2}$ & 0.408 & 0.397 & 0.385 & 0.373 & 0.362 & 0.35 & 0.338 & 0.327 & 0.315 & 0.303 & 0.292 \\
\hline$C_{3}$ & 0.35 & 0.34 & 0.33 & 0.32 & 0.31 & 0.3 & 0.29 & 0.28 & 0.27 & 0.26 & 0.25 \\
\hline$C_{4}$ & 0.117 & 0.113 & 0.11 & 0.107 & 0.103 & 0.1 & 0.097 & 0.093 & 0.090 & 0.087 & 0.083 \\
\hline Sum & $\mathrm{I}$ & $\mathrm{I}$ & $\mathrm{I}$ & $\mathrm{I}$ & $\mathrm{I}$ & $\mathrm{I}$ & $\mathrm{I}$ & $\mathrm{I}$ & $\mathrm{I}$ & $\mathrm{I}$ & $\mathrm{I}$ \\
\hline
\end{tabular}

Table 7.10 New weights based on the weight changed for the Social attribute (bypass road project)

\begin{tabular}{|c|c|c|c|c|c|c|c|c|c|c|c|}
\hline & $-50 \%$ & $-40 \%$ & $-30 \%$ & $-20 \%$ & $-10 \%$ & $0 \%$ & $+10 \%$ & $+20 \%$ & $+30 \%$ & $+40 \%$ & $+50 \%$ \\
\hline$C_{1}$ & 0.317 & 0.304 & 0.29 & 0.277 & 0.263 & 0.25 & 0.237 & 0.223 & 0.21 & 0.196 & 0.183 \\
\hline$C_{2}$ & 0.175 & 0.21 & 0.245 & 0.28 & 0.315 & 0.35 & 0.385 & 0.42 & 0.455 & 0.49 & 0.525 \\
\hline$C_{3}$ & $0.38 \mathrm{I}$ & 0.365 & 0.348 & 0.332 & 0.316 & 0.3 & 0.284 & 0.268 & 0.252 & 0.235 & 0.219 \\
\hline$C_{4}$ & 0.127 & 0.122 & 0.116 & $0.11 \mathrm{I}$ & 0.105 & 0.1 & 0.095 & 0.089 & 0.084 & 0.078 & 0.073 \\
\hline Sum & $\mathrm{I}$ & $\mathrm{I}$ & $\mathrm{I}$ & $\mathrm{I}$ & $\mathrm{I}$ & $\mathrm{I}$ & $\mathrm{I}$ & $\mathrm{I}$ & $\mathrm{I}$ & $\mathrm{I}$ & $\mathrm{I}$ \\
\hline
\end{tabular}

Table 7.I I New weights based on the weight changed for the Environmental attribute (bypass road project)

\begin{tabular}{|c|c|c|c|c|c|c|c|c|c|c|c|}
\hline & $-50 \%$ & $-40 \%$ & $-30 \%$ & $-20 \%$ & $-10 \%$ & $0 \%$ & $+10 \%$ & $+20 \%$ & $+30 \%$ & $+40 \%$ & $+50 \%$ \\
\hline$C_{1}$ & 0.304 & 0.293 & 0.282 & 0.271 & 0.261 & 0.25 & 0.239 & 0.229 & 0.218 & 0.207 & 0.196 \\
\hline$C_{2}$ & 0.425 & 0.41 & 0.395 & 0.38 & 0.365 & 0.35 & 0.335 & 0.32 & 0.305 & 0.29 & 0.275 \\
\hline$C_{3}$ & 0.15 & 0.18 & 0.21 & 0.24 & 0.27 & 0.3 & 0.33 & 0.36 & 0.39 & 0.42 & 0.45 \\
\hline$C_{4}$ & 0.121 & 0.117 & 0.113 & 0.109 & 0.104 & 0.1 & 0.096 & 0.091 & 0.087 & 0.083 & 0.079 \\
\hline Sum & $\mathrm{I}$ & $\mathrm{I}$ & $\mathrm{I}$ & $\mathrm{I}$ & $\mathrm{I}$ & $\mathrm{I}$ & $\mathrm{I}$ & $\mathrm{I}$ & $\mathrm{I}$ & $\mathrm{I}$ & $\mathrm{I}$ \\
\hline
\end{tabular}

Table 7.12 New weights based on the weight changed for the Project

Support attribute (bypass road project)

\begin{tabular}{|c|c|c|c|c|c|c|c|c|c|c|c|}
\hline & $-50 \%$ & $-40 \%$ & $-30 \%$ & $-20 \%$ & $-10 \%$ & $0 \%$ & $+10 \%$ & $+20 \%$ & $+30 \%$ & $+40 \%$ & $+50 \%$ \\
\hline$C_{1}$ & 0.264 & 0.261 & 0.258 & 0.256 & 0.253 & 0.25 & 0.247 & 0.244 & 0.242 & 0.239 & 0.236 \\
\hline$C_{2}$ & 0.369 & 0.366 & 0.362 & 0.358 & 0.354 & 0.35 & 0.346 & 0.342 & 0.338 & 0.334 & 0.331 \\
\hline$C_{3}$ & 0.317 & 0.313 & 0.31 & 0.307 & 0.303 & 0.3 & 0.297 & 0.293 & 0.29 & 0.287 & 0.283 \\
\hline$C_{4}$ & 0.05 & 0.06 & 0.07 & 0.08 & 0.09 & 0.1 & 0.11 & 0.12 & 0.13 & 0.14 & 0.15 \\
\hline Sum & $\mathrm{I}$ & $\mathrm{I}$ & $\mathrm{I}$ & $\mathrm{I}$ & $\mathrm{I}$ & $\mathrm{I}$ & $\mathrm{I}$ & $\mathrm{I}$ & $\mathrm{I}$ & $\mathrm{I}$ & $\mathrm{I}$ \\
\hline
\end{tabular}

The calculation results on weights in Table 7.9-7.12 show that changing the weight of one attribute affects the weight of other attributes and consequently yields a new weight vector. Increasing economic weight by $+10 \%$, for instance, generates a new weight vector: $[0.275,0.338,0.29,0.097]$.

Step 3: Run sensitivity analysis and calculate the new final score for all alternatives based on all sets of new weight vectors obtained in the previous step. 
Table 7.13 - 7.16 present the original and new final weighted scores for all alternatives which are calculated with regard to the attribute weights changed in the previous step.

Table 7.13 The original and new weighted scores based on the weights changed for the Economic attribute (bypass road project)

\begin{tabular}{|c|c|c|c|c|c|c|c|c|c|c|c|}
\hline $\boldsymbol{C}_{\boldsymbol{1}}$ & $-50 \%$ & $-40 \%$ & $-30 \%$ & $-20 \%$ & $-10 \%$ & $0 \%$ & $+10 \%$ & $+20 \%$ & $+30 \%$ & $+40 \%$ & $+50 \%$ \\
\cline { 1 - 10 } Alt & & & & & & & & & & & \\
\hline A & 99.17 & 99.00 & 98.84 & 98.67 & 98.5 & 98.34 & 98.17 & 98.01 & 97.84 & 97.67 & 97.51 \\
\hline B & 90.67 & 90.93 & 91.20 & 91.47 & 91.73 & 92.00 & 92.27 & 92.53 & 92.80 & 93.07 & 93.33 \\
\hline C & 97.17 & 97.25 & 97.33 & 97.41 & 97.49 & 97.57 & 97.66 & 97.74 & 97.82 & 97.90 & 97.98 \\
\hline D & 81.80 & 82.16 & 82.52 & 82.88 & 83.24 & 83.60 & 83.95 & 84.31 & 84.67 & 85.03 & 85.39 \\
\hline E & 87.70 & 88.05 & 88.41 & 88.76 & 89.11 & 89.46 & 89.81 & 90.16 & 90.51 & 90.86 & 91.22 \\
\hline F & 97.12 & 96.55 & 95.97 & 95.40 & 94.82 & 94.25 & 93.67 & 93.10 & 92.52 & 91.95 & 91.37 \\
\hline
\end{tabular}

Table 7.I4 The original and new weighted scores based on the weights changed for the Social attribute (bypass road project)

\begin{tabular}{|c|c|c|c|c|c|c|c|c|c|c|c|}
\hline $\boldsymbol{C}_{\boldsymbol{2}}$ & $-50 \%$ & $-40 \%$ & $-30 \%$ & $-20 \%$ & $-10 \%$ & $0 \%$ & $+10 \%$ & $+20 \%$ & $+30 \%$ & $+40 \%$ & $+50 \%$ \\
\cline { 1 - 10 } Alt & & & & & & & & & & & \\
\hline A & 97.89 & 97.98 & 98.07 & 98.16 & 98.25 & 98.34 & 98.43 & 98.52 & 98.61 & 98.70 & 98.79 \\
\hline B & 89.84 & 90.28 & 90.71 & 91.14 & 91.57 & 92.00 & 92.43 & 92.86 & 93.29 & 93.72 & 94.15 \\
\hline C & 98.79 & 98.54 & 98.30 & 98.06 & 97.82 & 97.57 & 97.33 & 97.09 & 96.85 & 96.60 & 96.36 \\
\hline D & 79.18 & 80.06 & 80.94 & 81.83 & 82.71 & 83.60 & 84.48 & 85.36 & 86.25 & 87.13 & 88.01 \\
\hline E & 87.15 & 87.61 & 88.07 & 88.53 & 89.00 & 89.46 & 89.92 & 90.38 & 90.85 & 91.31 & 91.77 \\
\hline F & 92.70 & 93.01 & 93.32 & 93.63 & 93.94 & 94.25 & 94.56 & 94.87 & 95.18 & 95.49 & 95.80 \\
\hline
\end{tabular}

Table 7.15 The original and new weighted scores based on the weights changed for the Environmental attribute (bypass road project)

\begin{tabular}{|c|c|c|c|c|c|c|c|c|c|c|c|}
\hline$\frac{C_{3}}{\text { Alt }}$ & $-50 \%$ & $-40 \%$ & $-30 \%$ & $-20 \%$ & $-10 \%$ & $0 \%$ & $+10 \%$ & $+20 \%$ & $+30 \%$ & $+40 \%$ & $+50 \%$ \\
\hline $\mathbf{A}$ & 97.98 & 88.05 & 98.12 & 98.20 & 98.27 & 98.34 & 98.41 & 8.48 & 8.55 & 98.62 & 98.69 \\
\hline B & 96.00 & 95.20 & 94.40 & 93.60 & 92.80 & 92.00 & 91.20 & 90.40 & 89.60 & 88.80 & 88.00 \\
\hline C & 97.05 & 97.16 & 97.26 & 97.37 & 97.47 & 97.57 & 97.68 & 97.78 & 97.89 & 97.99 & 98.09 \\
\hline D & 90.79 & 89.35 & 87.91 & 86.47 & 85.03 & 83.60 & 82.16 & 80.72 & 79.28 & 77.84 & 76.40 \\
\hline$E$ & 94.24 & 93.29 & 92.33 & 91.37 & 90.42 & 89.46 & 88.50 & 87.55 & 86.59 & 85.63 & 84.68 \\
\hline $\mathbf{F}$ & 93.01 & 93.26 & 93.51 & 93.75 & 94.00 & 94.25 & 94.49 & 94.74 & 94.99 & 95.23 & 95.48 \\
\hline
\end{tabular}

Table 7.16 The original and new weighted scores based on the weights changed for the Project support attribute (bypass road project)

\begin{tabular}{|c|c|c|c|c|c|c|c|c|c|c|c|}
\hline $\boldsymbol{C}_{\boldsymbol{4}}$ & $-50 \%$ & $-40 \%$ & $-30 \%$ & $-20 \%$ & $-10 \%$ & $0 \%$ & $+10 \%$ & $+20 \%$ & $+30 \%$ & $+40 \%$ & $+50 \%$ \\
\cline { 1 - 10 } Alt & & & & & & & & & & & \\
\hline A & 98.25 & 98.26 & 98.28 & 98.30 & 98.32 & 98.34 & 98.36 & 98.37 & 98.39 & 98.41 & 98.43 \\
\hline B & 91.55 & 91.64 & 91.73 & 91.82 & 91.91 & 92.00 & 92.09 & 92.18 & 92.27 & 92.35 & 92.44 \\
\hline C & 97.44 & 97.47 & 97.49 & 97.52 & 97.55 & 97.57 & 97.60 & 97.63 & 97.66 & 97.68 & 97.71 \\
\hline D & 82.68 & 82.87 & 83.05 & 83.23 & 83.41 & 83.60 & 83.78 & 83.96 & 84.14 & 84.32 & 84.51 \\
\hline E & 88.87 & 88.99 & 89.11 & 89.23 & 89.34 & 89.46 & 89.58 & 89.69 & 89.81 & 89.93 & 90.05 \\
\hline F & 93.93 & 93.99 & 94.06 & 94.12 & 94.18 & 94.25 & 94.31 & 94.38 & 94.44 & 94.50 & 94.57 \\
\hline
\end{tabular}


Based on Table 7.13 - 7.16, the original final weighted scores for all alternatives are shown in the $0 \%$ column and the new final weighted scores are presented in other columns. For example, the original score of alternative $A$ is 98.34 and, according to the same example in the previous step, the new final weighted score of alternative $A$ with regard to the new weight vector $[0.22,0.293,0.293$, 0.195 ] (economic weight increased $+10 \%$ ) is 98.17 .

The overall results of the sensitivity analysis based on changing weights can be presented in graphs. Figure 7.4 shows the graphs of three comparisons of alternatives, namely $A$ and $B, C$ and $D, E$ and $F$ respectively, with each graph presenting the changed final scores after the four attribute weight changes (economic, social, environmental, project support).

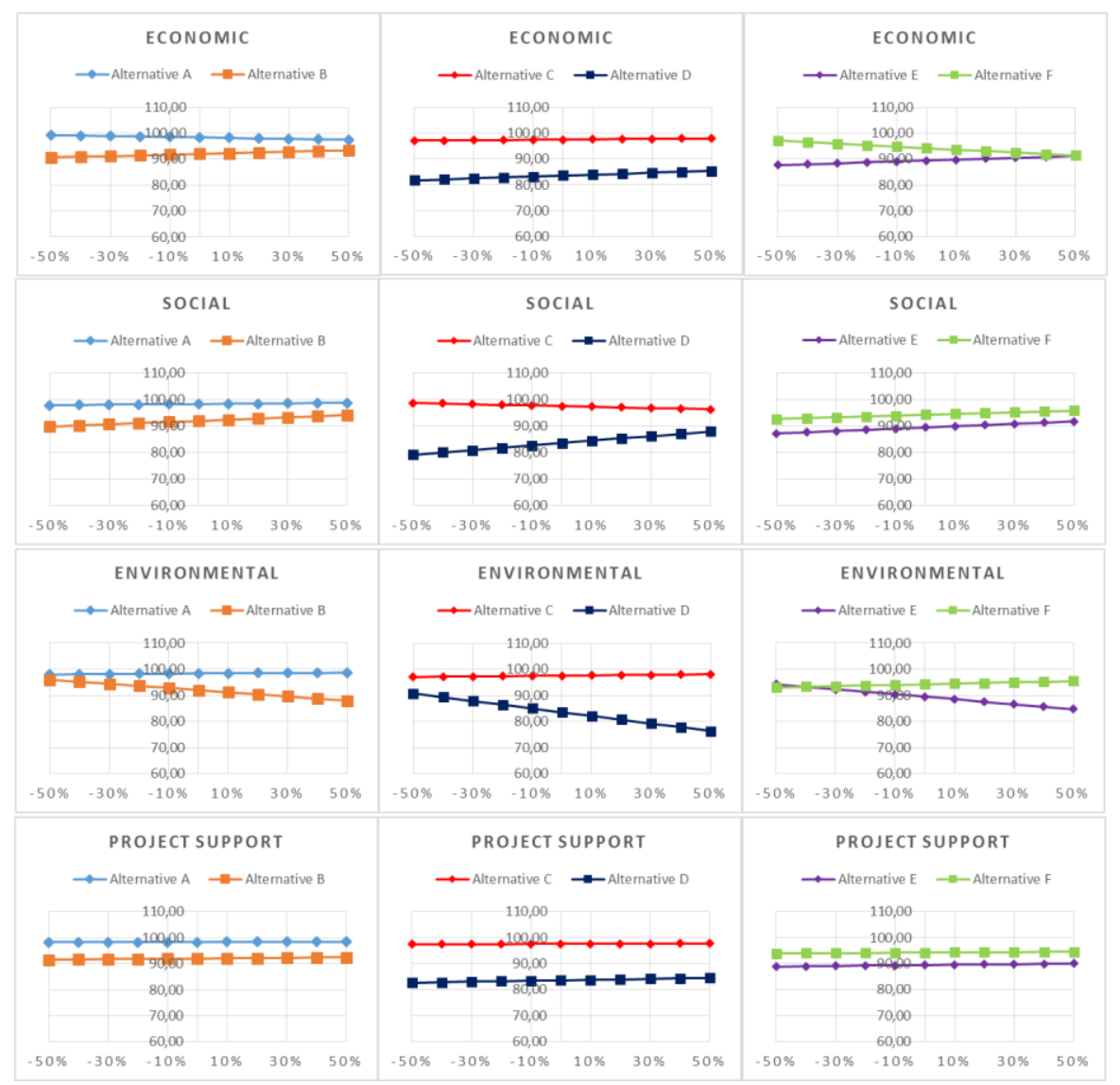

Figure 7.4 Changes in final scores for all alternatives based on changes in weights (bypass road project) 
The original ranks of the three comparisons are: $A>B, C>D, F>E$

Given the original ranks, the results are analysed for each pair of comparisons to support three distinct decisions.

For the first pair, the overall result of alternative $A$ and $B$ shows that the changes in attribute weights do not change the ranking. More specifically, alternative $A$ still retains the highest score and the final score of $A$ does not change much when the weights are changed. This case shows that alternative $A$ is not sensitive to any attribute weights. On the other hand, alternative $B$ is more sensitive to the changes in the social and environmental weights, despite its rank.

The sensitivity analysis of alternative $C$ and $D$ is presented in the same way as for the previous pair. It shows that changes in attributes weights do not affect their ranks. Alternative $C$ is still in first place and its final score is not likely sensitive to changes in attributes weights, while alternative $D$ is very sensitive to the changes in social and environmental weights.

The last comparison is between alternative $E$ and $F$, and the analyses of this pair show that alternative $F$, the preferred option, is likely sensitive to the changes in economic weight while alternative $E$ is more sensitive to environmental weight changes. The latter case can change the ranks of alternatives, as alternative $E$ will rank highest if the environmental weight is decreased by $40 \%$. On the contrary, the first case also can be significant if the economic weight is increased by $+50 \%$, at which point both alternatives have very similar final scores. In this pair, social and project support weights do not have much influence on the ranks and the final scores of both alternatives.

According to the sensitivity analysis for all three comparisons, there are no significant changes in the final scores and ranks of alternatives related to the weight changed for the project support attribute. It is clear that because all alternatives have an identical score on the project support attribute, weight changes to this attribute will not make a difference.

As was done in the previous case in section 7.2.2, the second analysis assumes that the project support scores of each pair of alternatives are different. To do so, the scores of alternatives $B, D$ and $E$ are adjusted by giving them a score of 3 (strong support by stakeholders and local community) instead of 2, as was originally the case. Thus, they have a different project support rating than their competing alternatives. Accordingly, the final scores of the alternatives are 
recalculated to examine the result by using all sets of new weight vector generated in step 2. Figure 7.5 shows the sensitivity analysis based on the different project support scores of each pair.

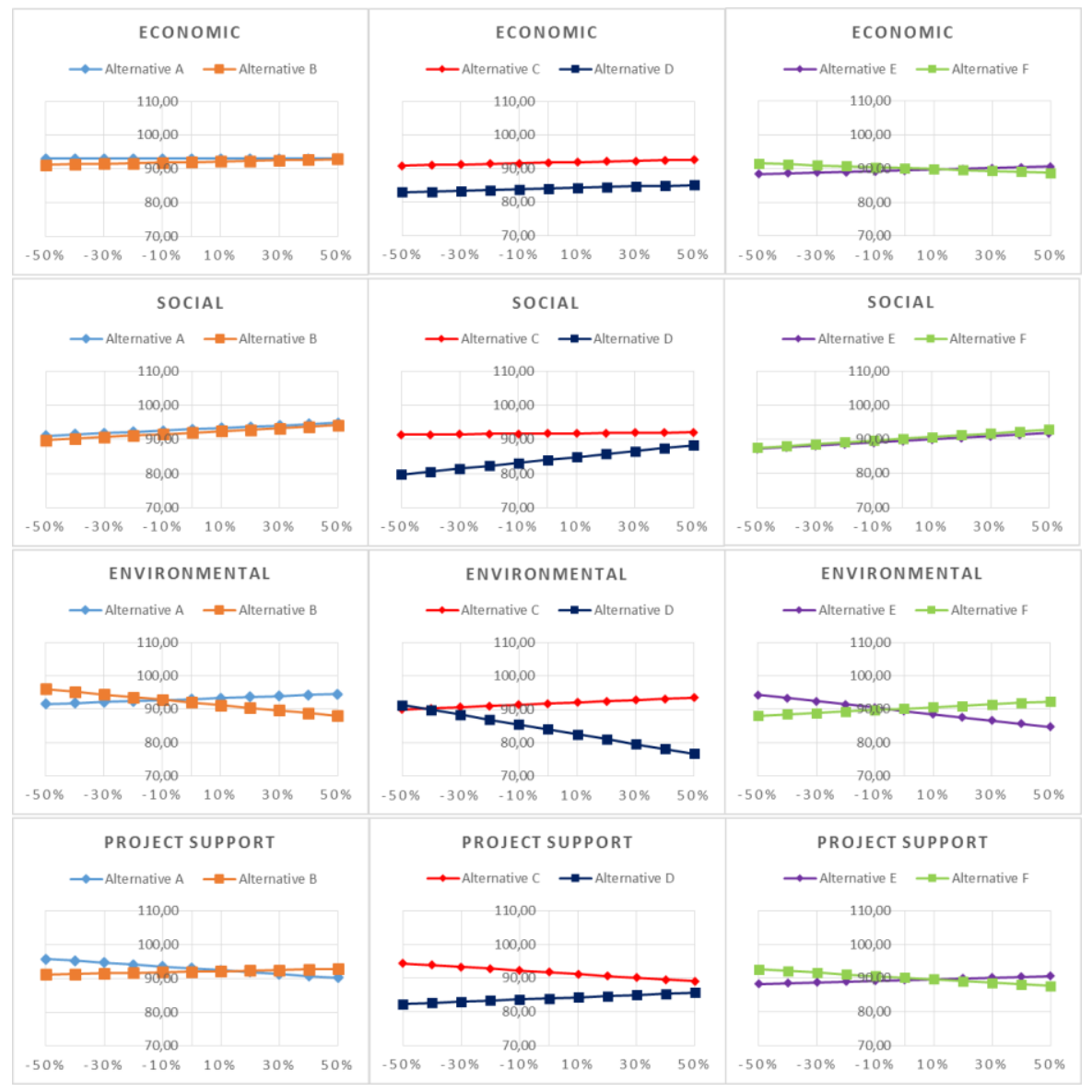

Figure 7.5 Sensitivity analysis based on adjusting the project support score of $B, D$ and $E$ (bypass road project)

The analysis involved comparing the results with the first test in Figure 7.4 and the second test in Figure 7.5.

When the project support score of alternative $B$ is adjusted, the final scores of alternative $A$ and $B$ become very similar. Despite their similar scores, the changes in economic and social weights do not affect their ranks. However, the ranking does change when the weights of the environmental and project support attributes are adjusted by only $10 \%$. Moreover, alternative $A$ is, in this case, 
more sensitive to the changes in project support weight. This is due to its lower score on the project support attribute.

The adjusted project support score for alternative $D$ results in a lower final score of alternative $C$. However alternative $C$ retains first place, beating alternative $D$ in most cases. Alternative $D$ will get a higher score and will take over first place from $C$ only when the environmental weight is decreased by $50 \%$.

The sensitivity analysis on alternative $E$ and $F$ demonstrates that adjusting the project support score of alternative $E$ leads to both alternatives having similar final scores. Both alternatives are also sensitive to the changes in the economic, environmental and project support attribute weights. Changes in attributes weights by $+20 \%$ economic, $-10 \%$ environmental and $+10 \%$ project support can change the order of the ranking.

\subsubsection{Conclusion}

Most of the data used in public problem-solving and decision-making are changeable and are, in many cases, on an ad hoc basis. Therefore, conducting a sensitivity analysis after a problem-solving process is a very useful way to supply decision-makers with different scenarios to help them make accurate decisions. In this PhD thesis, the proposed IDM is applied to two project cases and provides evaluation results for a selection. The sensitivity analysis in this study is used to test the robustness of the evaluation results which rely on the attribute weights assigned by one or more decision-maker(s), which calls for a sensitivity analysis on weights. The test results demonstrate that the changes in attributes weights could lead to changes in the final evaluation scores and the ranking of alternatives. The sensitivity analysis presents the evaluation results in as many scenarios as the test cases. The scenarios are established on the basis of many new sets of attribute weight vectors, calculated by changing only one attribute weight at a time to provide better information for decision-maker in all circumstances. The tests also highlight that scores on all attributes are significant and have meaning. If the data used for an evaluation has no significant influence on the final scores and ranks of alternatives, as is the case when all alternatives have the same project support scores, for instance, it is suggested to omit that attribute from the evaluation. However, seeing as one of the intentions of IDM is to promote public participation, the existing data points to a need to improve the way of generating stakeholders and local community 
involvement and collaboration so that they can be meaningfully included in the project evaluation and decision process. 


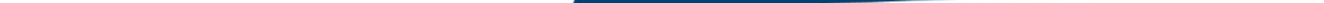




\section{DISCUSSION AND CONCLUSION}

The main goal of this study has been to develop an integrated decision model that can be used to assist decision-making authorities to select the most suitable alternatives and subsequently improve the quality of the evaluation and selection process for public investment projects. To achieve this goal, this thesis has provided answers to the following research questions:

I) What approaches and techniques are available in the field of project evaluation and decision-making in the public sector?

I.I) What possible evaluation techniques and their concepts are available and what are their strengths and weaknesses?

I.2) What relevant decision-making approaches and techniques are available for public investment project decisions and what are their respective strengths and weaknesses?

2) What is the current state of the process of the public investment project selection process in Thailand?

3) How to incorporate the various concepts and techniques from different disciplines into one integrated model to improve project evaluation and selection processes?

4) How to validate and test the correctness, efficiency and adaptability of the developed model?

In this final chapter, the findings and results of each research question are summarised and discussed in section 8.1. Section 8.2 and 8.3, respectively, describe the scientific and practical contributions of this study. The limitations of this $\mathrm{PhD}$ study and suggestions for future research are addressed in section 8.4.

\section{I SUMMARY OF RESULTS AND GENERAL DISCUSSION}

This section elaborates on four topics of discussion originating from the four research questions of this $\mathrm{PhD}$ study. The first discussion in section 8.I.I focuses on the theoretical background of the principles and techniques of project evaluation and decision-making. The discussion points to the possible approaches and techniques that can be applied. Section 8.I.2 presents the main findings of the analysis on the state of evaluating and selecting public investment projects in Thailand. Section 8.I.3 describes the development of an integrated evaluation and selection model for public investment projects and includes a 
discussion on the application of the developed integrated model (IDM) for two real case projects. Finally, the assessment and testing of IDM are addressed in section 8.I.4.

\section{I.I Theoretical background on project evaluation and decision-making}

In Chapter 2 and 3, there is a large amount of literature available about the project evaluation approaches and the systematic processes for making decisions, but decision-makers currently struggle to apply these principles in practice when evaluating and selecting public investment projects. The literature on project evaluation and the decision-making process also shows the pitfalls and difficulties associated with adopting the process in practice. Different organisations and countries have their own characteristics and many factors influence the way a decision can be made.

Economic methods, especially discounted cash flow techniques (DCF), seem popular for policy-makers looking to pursue their investment objectives. A wellknown benefit of DCF is that it shows the cost-benefit of a project with regard to the real value of money over time (Abdullah \& Nordin, 2008). The NPV, IRR and $\mathrm{B} / \mathrm{C}$ ratio are the most popular methods in this approach. Which of these methods is best and how to choose either one of them or combination of all for an investment evaluation are still questions in an inconclusive debate. Although a theoretical consensus has not been reached yet on this issue, a considerable amount of work shows a trend of economic evaluations that seems to be shifting towards the NPV technique (Osborne, 2010; Mahmoodzadeh, et al., 2007). The NPV calculation requires costs and benefits expressed in a monetary unit. However, in cases where benefits cannot be measured in a monetary unit, such as when considering the qualitative outcome of a project, it will not be possible to perform an NPV. In this case, the CEA is seen as a more appropriate economic technique to capture the overall benefits and to present the result in a ratio of incremental cost to incremental effect (Dawson, 2008; Sanders, et al., 2016).

The review also indicates that economic measures are commonly used to evaluate a project's impact on society. However, many debates have recognised the difficulties with applying these measures in the social domain and there is still little agreement about what is an appropriate approach to account for the social issues. 
Besides economic methods, non-economic approaches and methods have also been reviewed. The non-economic methods are needed to measure the impact of a specific investment on society, environment, and public participation. The review of social evaluation research indicates that public policy-makers tend to focus on subjective social evaluations which are related to improvement of quality of life and well-being of people living in their environment. Moreover, the problem of the sub-optimal distribution of income and benefits is a crucial concern for governments in developing countries.

Although the attempt to include social and environmental issues and stakeholders and public participation points of view into project assessments has made significant progress over the last few decades, the expectations on how these aspects will influence the decision-making process are still causing a lot of debate. The well-known EIA/SEA is a widely accepted tool for assessing the environmental implications and, for the most part, it also includes considerations of social issues and a participation procedure. Many deficiencies remain in the EIA/SEA system, however, including issues of inadequate public participation and the lack of integrating the environmental impact of an investment into the decision-making process (ONEP, 2004a; TEI, 2005; Wirutskulshai, et al., 20I I). These issues may be due to the fact that the EIA/SEA process mainly focuses on proposing mitigation policies and producing a formal report of its results rather than comparing alternatives and making a selection between alternative choices.

The review also shows that although the decision-making processes presented in the literature are well-structured, organizing the process can be challenging in practice, caused by a variety of factors. Most public investment decisions are complex and the selection of investment projects often also involves conflicting values and criteria. Due to the inherent complexity, it will be difficult for a human mind to deduce a rational way of analysis when the selection of individual projects is no longer based on a single criterion but depends on multiple criteria/attributes. The theoretical review and evidence in practice indicate the need, therefore, to use multiple-criteria decision-making/analysis methods (MCDM/MCDA), which have shown their usefulness in helping decision-makers (or researchers and practitioners) improve the quality of their decisions and make the process more explicit.

Since there is a lack of consensus about which methods and methodologies are most appropriate for specific decision situations, the selection of an appropriate 
evaluation and decision-making method is not an easy task. It depends very much on the intended objectives and the specific characteristics of an organisation or a country. Moreover, the literature review also shows a lack of interaction and integration between methods from different disciplines. This is to say that different issues have different importance to experts in different areas. The literature review and the diagnosed problems in practice raised the question of how to include, measure and integrate the required aspects and criteria by using of appropriate economic and non-economic evaluation methods to improve the process of evaluation and selection of public investment projects in Thailand.

\subsubsection{The current state and challenges of the evaluation and selection of public investment projects in Thailand}

\section{Problems in the current procedure}

To achieve the objectives of this study, understanding the substantial problems inherent in the current situation is a stepping stone to a solution. General problems related to difficulties in practice of public investment and decisionmaking are presented in Chapter 4. It has been noticed that in most developing or middle-to-low-income countries, public investment faces an imbalance between national economic growth and the well-being of citizens. Thailand was chosen as a representative case of a developing country to thoroughly investigate the main shortcomings and possible improvements in the current state of evaluating and selecting public investment projects. Literature (e.g. Dabla-Norris et al., 2012; Krueathep, 2008; Vichit-Vadakan, 20I I) and empirical experience have shone more light on the negative state of public administration and investment in Thailand. However, a deeper analysis on the problems of the current decision-making process, appeared necessary.

One of the main findings in this part is the absence of standard guidelines or a general applied methodology to evaluate the benefits of public investment projects and to assist in their selection. The ways in which project benefits are assessed and measured vary widely per agency, depending on the knowledge backgrounds, the capabilities and the perceptions of the people in question. Even though there is a formal requirement that high-impact projects must provide a proper impact assessment (such as EIA, IEE, SEA) that considers economic, social and environmental factors and public participation, the results of the assessment are not included in the evaluation and the final decision. In 
sum, the findings of this part indicate that the current system of project assessment and selection in Thailand shows a lack of integration of all the essential impact of a project.

The findings also show that the comparison between projects is one-sided and based solely on economic measurements, overlooking other important areas of investment impacts that projects may have on e.g. society and the environment. Moreover, in most cases, the impact assessment of a project is carried out without meaningful public participation. Genuine public participation would open up opportunities for stakeholders and local communities to be involved in the decision-making process (TEl, 2005; Wirutskulshai, et al., 20II). The findings identified in the process of evaluation and selection of public investment projects challenge this $\mathrm{PhD}$ study to seek out solutions to improve the process of evaluation and selection of public investment projects in Thailand.

\section{Important required aspects}

One component of the solution is to search for the most important aspects that a public investment project in Thailand is supposed to meet. As presented in section 4.3.3, this search process resulted in the identification of eleven criteria, across five aspects which were selected by 52 evaluators and experts and applied to the entire public investment decision-making process. Based on the analysis of the selection result, some are appropriate at the pre-screening stage and some for the policy decision. Among those eleven criteria and five aspects, however, seven criteria in four aspects are suitable for the individual project evaluation and selection process at the project level, which was the main focus of this PhD study.

The search process revealed four important aspects, i.e. economic, social, environmental and long-term support aspects. These four aspects demonstrate a new development trend in which the economic return of an investment is no longer the only aspect to be considered from a public point of view. Public awareness of the potential environmental impact of investment decisions and the increasing interest in social issues require evaluators to also assess how investment projects affect the natural environment and society (Haughton, et al., 2009; Bond, et al., 2012; Cadena \& Magro, 2015). Moreover, the long-term support aspect indicates the importance of incorporating stakeholders in the decision-making process and of securing the cooperation and involvement of local communities. Table 8.I presents the four aspects and corresponding seven criteria for evaluating and selecting public investment projects in Thailand. 
Table 8.I: Selected criteria for public investment project evaluation and selection

\begin{tabular}{|l|l|l|}
\hline \multicolumn{1}{|c|}{ Decision stage } & \multicolumn{1}{|c|}{ Aspects } & \multicolumn{1}{c|}{ Criteria } \\
\hline $\begin{array}{l}\text { Individual project } \\
\text { evaluation and selection } \\
\text { (at the project level) }\end{array}$ & Economic & Economic viability \\
\cline { 3 - 3 } & \multirow{4}{*}{ Social } & Area-based requirement/priority \\
\cline { 3 - 3 } & & Distributional effects \\
\cline { 3 - 3 } & Impacts on quality of life in the target area \\
\cline { 2 - 3 } & $\begin{array}{l}\text { Effects on local employment and economic } \\
\text { activities }\end{array}$ \\
\cline { 2 - 3 } & \multirow{2}{*}{ Environmental } & $\begin{array}{l}\text { Natural resources and environmental } \\
\text { disturbance/ impact }\end{array}$ \\
\cline { 2 - 3 } & $\begin{array}{l}\text { Long-term } \\
\text { support }\end{array}$ & Community cooperation and collaboration \\
\hline
\end{tabular}

The selection of environmental and social criteria by experts indicates a need for a detailed measure of a project in the country's current situation. With respect to the social aspect, it is interesting to note that four out of the seven selected criteria are related to social issues. The first two criteria, 'Area-based requirement priority' and 'Distributional effects', have an intrinsic relationship which indicates the need to consider the affected areas and see how the project's impacts will be distributed to different population groups within these areas. It is also necessary to consider the requirement priorities among those population groups to support the evaluation. The two other aspects, 'Impacts on quality of life in the target area', and 'Effects on local employment and economic activities', reflect the important effects of a project on socio-economic and social wellbeing in the area. Including these new social criteria signifies a new direction for evaluating an investment project, which intends to measure the social impact on different groups of people. An investment project that brings more benefits to disadvantaged people will be prioritised higher.

While there are four criteria in social aspects in the selection, only one environmental criterion has been selected. Most experts agreed to include the essential impact 'Natural resources and environmental disturbance/impact'. The affinity of the experts with this criterion may be partly due to the statutory environmental regulation which is mandatory for any high-impact project.

The last selected criterion for the project level belongs to long-term support aspect and constitutes 'Community cooperation and collaboration'. Whereas the benefits of general public participation are well known, the role of stakeholders and local communities, as well as their involvement in a decision, remain 
unknown (Charuvichaipong \& Sajor, 2006; Maneepong \& Webster, 2008; Wirutskulshai, et al., 20II). The selection of this criterion indicates a need for collaboration in a project between government agencies and local communities. This signifies that if a project is characterised by strong collaboration and communication between various stakeholders, it will have a higher chance for long-term success.

\section{I.3 The development of an integrated decision model for evaluation and selection of public investment projects}

In Chapter 5, the results of the literature review and the current shortcomings and the requirements for improvement were utilised to design the solution for the development of an integrated decision model (IDM). In the proposed IDM, different methods are utilised at different stages throughout the methodology as shown in Figure 8.I.

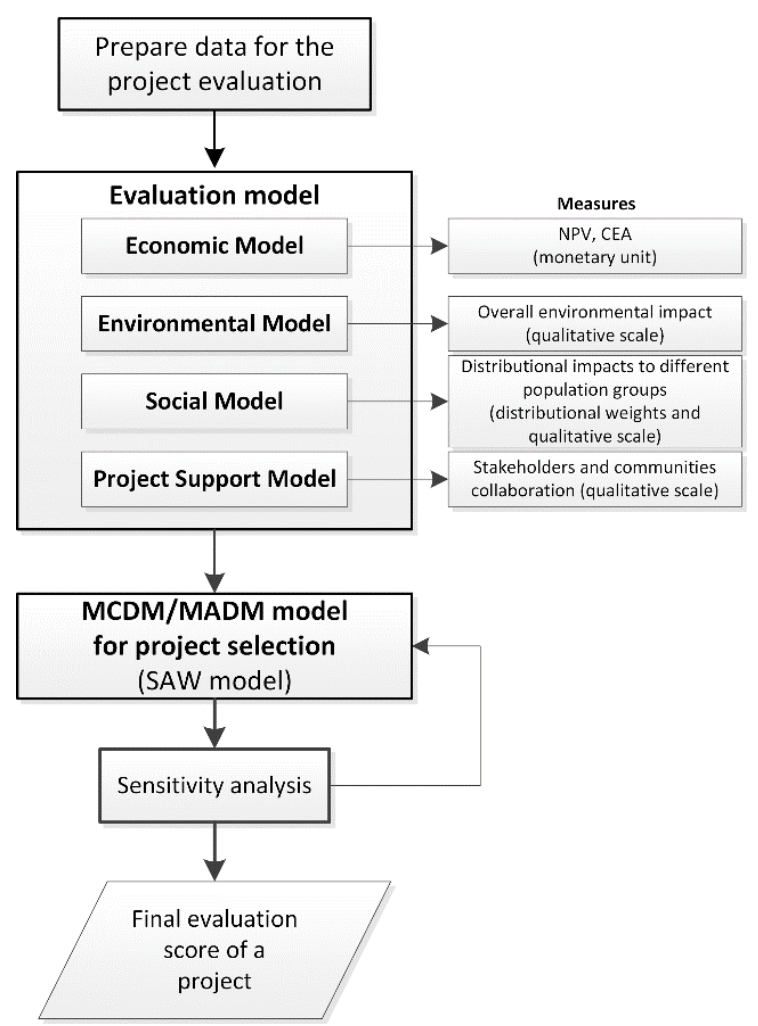

Figure 8.I Proposed methodology for public investment project evaluation and selection 
Moreover, the methodology has been designed to be flexible enough to allow users to add additional models to evaluate additional criteria or to replace the original ones with new ones with a relative ease. This function will not change the overall concepts of the methodology but is purposely open to future improvements.

Based on the application of the developed IDM to two real cases, the conclusion seems justified that the proposed methodology is appropriate for evaluating and selecting individual public investment projects in Thailand. The application to the cases also showcases the advantages of the proposed IDM, demonstrating that it will improve the current process of evaluating and selecting public investment projects.

First, the proposed evaluation and decision-making methods in the IDM provide a better understanding of a project's evaluation results.

- The use of NPV in the economic model is suitable at both local and regional scale projects. The proposed NPV provides a clearer result than the currently used IRR. For a local project where monetary cost is the only available information and not enough data is available to perform the NPV, the CEA can be applied to measure the costeffectiveness of the project. These two methods are consistent, because the results of both methods are expressed in monetary units, which makes it easy to compare the economic benefits of alternatives.

- The use of population compositions based on income level and the priority weights in the social model helps to manage complexity in the project area and provides a clearer picture of the possible interactions between each alternative and the community groups affected by it.

- The use of a qualitative rating scale in the proposed IDM methodology can enhance the highly descriptive character of the current environmental assessment and public participation description in EIA/IEE reports. Applying the qualitative rating scale will make the comparison between alternatives simpler and easier to conduct.

- The final selection decision on the best alternative is achieved using the SAW model from the MADM/MCDM approach, which brings together different units in quantitative and qualitative assessments from various evaluation models into a single final evaluation score for an investment project. According to current practice in Thailand, the project evaluation and selection process is mainly organised by evaluators or 
project analysts at the project level, and executive decision-makers are not as involved. The application of the IDM demonstrates its suitability for such a system. A decision-maker's preference is required only at the last stage, when assigning the attributes weights for the SAW model. In practice, the weights can be assigned by the evaluator/project analyst, who can subsequently make an initial assessment and provide the evaluation results to the executives to make the final selection.

Secondly, the application of IDM to the cases shows the usefulness of the flexibility in the design of the methodology. The Bypass Road Project case, in particular, demonstrates that this feature can resolve the problem of limited project data, as the suggested model (NPV) could easily be replaced by an alternative model (CEA). Based on the cases, this flexibility is necessary in order to provide possible adjustability in the future, because different projects may require different objectives and indicators for the evaluation. In addition, replacing one model with a relatively easy alternative, as was been done in the applied case, does not change the underlying concept of the methodology.

Thirdly, the application of the IDM shows that the existing data that was used for the current assessment of both project cases can be used in the IDM, although it required a little effort to transform the original data into a more preferred form. However, the use of existing data has a major influence in the project support model. As seen in both cases, the project support attribute produces the same scores for all alternatives, thus indicating that this attribute was not significant in the original assessments. Applying the IDM and including this attribute therefore satisfies the intention of the designed concept, which is to promote the importance of collaboration between government agencies and local communities and incorporating the results into the evaluation and selection process. Project data must be improved in order to support the evaluation of the project support aspect for implementation in the future.

To this end, the remarks received on usefulness and the remarks received after the application of the model to two project cases seem to justify the conclusion that the developed IDM and its methodology are appropriate and adaptable for evaluating and selecting public investment projects in Thailand, especially those with regional and local impact. Moreover, it also indicates that the flexibility of the IDM is very useful when the government has to deal with the evaluation of various types of projects which require different indicators to achieve their objectives. 


\section{I.4 Effectiveness of the decision model and robustness of the selected choice}

In order to test and assess the effectiveness of the developed IDM, an appraisal and sensitivity analysis was conducted in two parts.

Firstly, the developed IDM was assessed in terms of its ease of use, suitability and adaptability. How the IDM works throughout the entire methodology and the initial figures of application were presented to a total number of 40 experts from relevant organisations in Thailand. A questionnaire was also sent by e-mail to the experts to request for feedback. $75 \%$ of the experts responded to the request and provided their feedback. As has been discussed in chapter 7 , the assessments by the experts indicate that the proposed methodology is easy to follow and apply. The experts also indicated unanimously that the IDM covers all the important factors and variables required for evaluating and selecting public investment projects in Thailand. They also agreed that applying the proposed IDM represents a substantial improvement on the current procedure, because it provides more insight into how the alternatives impact social and environmental issues. Hence, IDM provides better information for a more informed decision for the most effective solution. Some experts expressed a concern that not all evaluators may be familiar with the use of the proposed methods and do not have much experience in translating information and subjective judgements into a measurable indicator, but the researcher believes that future substantial practice can handle these issues with specific training and the development of an automated tool to support the calculation.

Secondly, a sensitivity analysis was conducted on the weights included in the IDM to test the robustness of the selected choice. The testing indicates that the attribute scores and weights affect the decision result. Small changes in some attribute weights can change the final scores and original rankings. This provides decision-makers and evaluators with insight into the input that influences the outputs of the decision model and thus means that the robust alternatives that are not highly sensitive to these changes should be considered as a potential choice. 


\subsection{SCIENTIFIC CONTRIBUTIONS}

This study uses an in-depth understanding of theory and practices to enable the design of a model of the interactions between projects with respect to the priority of both their strategic objectives and the needs of local communities. This has resulted into the development of an integrated decision model (IDM) which is aimed to assist decision-makers in the process of evaluating projects and choosing between various options. The new decision model is designed and developed by moving forward the evaluation and selection that is not only focused on economic growth of the country as it was the case in many traditional assessment, but includes the impacts on society and communities as well as natural environment which are not considered in the current process.

The integration of various evaluation and decision-making techniques is innovative in order to improve the current state of public investment evaluation and selection in Thailand by potentially addressing the important attributes (economic, social, environmental, project support) and supporting decision makers to investigate the interaction between project and its effects to communities.

The integrated decision model (IDM) and its methodology are generic, which means that they can be applied by any public organisation looking to improve its investment project selection procedure. The methodology consists of two fundamental elements. The first involves the evaluation of the different investment alternatives, whereas the second element acts as the general decision framework within which projects are analysed and selected. The consideration of using different approaches to model diverse important evaluation aspects and incorporate them into one model presents a more effective selection process and contributes to scientific knowledge in a positive way.

Moreover the social model in the IDM that incorporates distributional weights and different affected population groups is novel which was not seen in literature in the field of public investment project evaluation and selection. The model provides a clearer picture of the possible interactions between a project and the community groups affected by it and eventually the social impact can be included into a decision. 


\subsection{PRACTICAL CONTRIBUTIONS}

Public investment projects are seen as an important tool to allocate public resources in order to improve the situation of a country, but in many cases the benefits of those projects remain obscure. Thailand, just like many other developing countries, lags behind in terms of quality of life and well-being and also shows deficiencies in the application of new knowledge and techniques to support the allocation of limited public resources. Therefore, the development of a more effective model to improve the interaction between the investment projects and community will help to improve life in general.

The IDM integrates all important factors required for the country's development: economic, social, and environmental aspects and stakeholder involvement (project support). It produces a higher-quality approach to selecting public investment projects in a country, which allows for a more effective distribution of project benefits to equitably improve the living standards of the population and bridge the gaps between urban societies and rural areas.

The result produced by the IDM is transparent and the project benefits to society can be traced back if required. This is also significantly useful for organisations that need to prove project benefits for a budget approval.

\subsection{LIMITATIONS AND SUGGESTIONS FOR FUTURE RESEARCH}

This section presents important limitations of this $\mathrm{PhD}$ study and the suggestions for further research inspired by the limitations and insights gained while conducting the study.

\subsection{Limitations}

I) The entire public investment decision system comprises various levels of decision. However, this research has been focused only on the process of project evaluation and selection at the project level. Other levels of decision which are the Budget-Screening level and the Policy level have been not much described and are not included in this study.

2) The application of two cases has been carried out based on the existing information of the project which shows lack of project data to be used as input in the model. As a result of this limitation, there are many assumptions adopted to experiment how the proposed IDM and its 
methodology are applied in a certain project case. Therefore, the results of the application can only perform a demonstration of the developed methodology for testing its adaptability and flexibility, but cannot be used to replace the decision which was done in the current assessment.

3) The scope of this PhD study has been limited to the test cases in the construction domain by applying the proposed IDM to a structural irrigation development (water sector) and local bypass road construction project (transport sector). More cases in the construction domain should be tested as well as cases in other important sectors.

\subsubsection{Suggestions for future research}

\section{Extension of the methodology}

This suggestion is inspired by a limitation of this research in Section 8.4.I (I) which focuses on the process of project evaluation and selection at the project level. To achieve the final decision and officially enact it for an implementation, the integration of the entire public investment decision system is required, which covers all levels of authority (budget-screening level, project level, and policy level) from the start to the end of the decision-making process.

The overall picture of the entire system is that the budget-screening level has been structured well, according to the current practice studied. A structured process for selecting individual projects at the project level has also been suggested in this thesis. Nonetheless, for the end process at the policy level, it still remains unclear how this policy level makes decisions on the project portfolio level. In other words, research on the policy level should be focused on the consequences of interrelated projects which combine potential individual projects into a programme. Extending the methodology to cover this policy level will enhance the improvement of the current system as a full package for various decision-making levels.

\section{Advancing project data for more accurate assessment}

Regarding the limitation on lack of data in Section 8.4.I (2), especially in the social and project support aspects, this raises future challenges for improving the current way of acquiring the project data. Firstly the way of incorporating local network collaboration and stakeholders engagement should be enhanced by redesigning future devolution policies that fully promote these initiatives for the long-term success of selected projects. There are various participatory 
approaches which could be separately applied to conduct this issue. For example the use of participatory MCDA in which values of different parties are devised (see e.g. Scott, 2005; Salgado et al. 2009); or applying the Social License to Operate (SLO) in participatory activities in order to achieve the acceptance or approval by indigenous people in a certain area (see e.g. Demuijnck and Fasterling 2016; Wilburn and Wilburn 20II).

Secondly, measuring social impacts can be enhanced by improving project data acquisition which is required for different population groups. The improvement of social data can be done in many ways, such as a field survey in different areas, an additional geographical database to support more information for evaluators, extending the assessment team with more experts in various relevant fields.

Finally, in some cases, the complexity of social and environmental issues could be problematic and would be diluted by attributing numbers to all the factors using the qualitative rating scale. A recommendation can be that the experts who conduct the primary assessment data (e.g. EIA/IEE report) should work closely with project evaluators in order to examine how these critical issues can be adequately addressed. Moreover, if necessary, an extension of the social model especially the part of QoL can be further studied to identify many other social impacts, such as cultural and traditional environment impacts, which can occur and which should be carefully assessed.

\section{Application to different types of public investment projects}

This suggestion is related to the limitation in Section 8.4.I (3) in the applicability of the proposed IDM to different types of projects. The scope of this study has been limited to the test cases in the construction domain. This limitation encourages further research and the application of the IDM to other important sectors, such as energy, education and healthcare. Furthermore, when the need for public investment projects goes beyond the construction domain and nonstructural projects are required(e.g. associated with the design of institutions, the adoption of new mechanisms, the development legal and regulatory frameworks), these kinds of projects should be used as a case to test whether the IDM is also appropriate for evaluation and selection in these sectors. Further research on this matter would provide profound insights into strengths and weaknesses of the methodology, allowing it to be fine-tuned.

\section{Computer software development}

The proposed IDM has applied various methods and contains a number of different calculations for various variables in the model. According to the 
comments by several of the experts that were involved during the assessment of the IDM, using some of the methods may prove difficult, due to the complex calculations involved. The suggestion is made here to develop computer software that provides a step-by-step outline following the methodology and which will support non-technical users in particular by providing automated calculations, thus making the workflow faster and easier. Moreover, assessing project impact, especially in the social model, requires external information to be used as variables, such as income levels and the boundaries of affected areas. The development of an effective database that links all relevant information from external sources (e.g. census tracts, geographic information) to the model is suggested, to guarantee that these variables stay up-to-date and are always ready for use, improving the efficiency of IDM implementation. 


\title{
Appendix
}

\section{Scientific Journal Paper}

\author{
An Integrated Decision Model \\ for Public Investment Project Selection in \\ Developing Countries: \\ a Case Study in Thailand
}

Pintip Vajarothai

Saad Al-jibouri

Johannes I.M. Halman

Under the third review 


\section{ABSTRACT}

Empirical evidence and literature show that public investments, particularly in developing countries, often struggle, or fail, to satisfy the objectives they were originally intended to achieve, especially when it comes to delivering benefits to citizens. A major reason for this is related to the way potential public investment projects are evaluated and selected. This paper proposes a structured methodology, based on an integrated decision model, to improve the project evaluation and selection process. The proposed model integrates economic, social, environmental and project support attributes in a single model. The proposed model has been applied and is shown to add value for an irrigation development project for the Yom River Basin in Thailand. 


\section{Introduction}

Public investment projects are generally defined as solutions that allocate public resources in order to achieve economic growth and to help meet a country's social development goals (Jó and Barry 2008). They often involve investing in the construction of infrastructure (e.g. roads, reservoirs, energy supply and buildings) and the acquisition of equipment and technology (e.g. defence, information and communication technology). These projects usually go through a process in which alternatives are evaluated to find the most suitable and effective solution to address the original problems and needs. As such, the process involves decision-making, an essential part of the whole investment process, to determine the most suitable option among various alternatives. The project evaluation and decision-making disciplines are evolving, offering critical implications for many areas of study. While many advances have been made in the theoretical development of these disciplines, their more practical aspects remain unstructured and lack a strong foundation (Belton and Stewart 2002). As published work and practice indicate, the process has many problems, especially in developing countries. In many developing or low-income countries, governments initiate numerous investment projects to improve their population's conditions and quality of life. However, despite all these efforts, there is often a failure to achieve considerable improvements in local conditions or in the quality of life of the communities. A study by Fosu (2017) highlights the growing disparities in income and other inequalities between urban and rural areas over two decades, specifically in East Asia and Pacific, South Asia and Sub-Saharan Africa. Relevant research demonstrates that, in many cases, such failures are caused by the way public investment projects are evaluated and selected (Grindle 2004; Fang and Sakellariou 2013; Jó and Barry 2008; Reardon and Vosti 1995).

Considering Thailand, as a case example, research shows that, despite the numerous investments in public projects, the gaps in income and inequality between rural and urban areas remain wide (Fan et al. 2004; Deolalikar 2002). This is caused by the government's urban-biased investment, which results in concentrations of poor people in the rural areas (Fan et al. 2004). It should be noted that this comparison between investment projects in Thailand is limited to economic measurements and ignores other important aspects such as the societal and environmental impacts of an investment project. Moreover, in most cases, and especially with non-donor projects, the evaluation and selection is 
carried out without the involvement or consideration of stakeholders and local communities and their needs. Although, some projects that are financed by donors do involve more support and involvement, the procedure used to appraise competing proposed projects still lacks transparency (Miller and Mustapha 2016). These observations are supported in a publication by DablaNorris et al. (20I2) that highlights that Thailand scores very poorly, even among middle and low-income countries, in terms of the transparency of its selection procedure. Although developing countries often lack formal standard methods and systems to evaluate a project's benefits and impacts (Shiferaw et al. 2012; Klakegg 2009; Besley and Coate 2003), there are established practices (e.g. CBA) and international guidelines (e.g. World Bank, IMF) available to assist in reaching a sound decision (see e.g. World Bank 20I2; Rajaram et al. 20I0).

This paper describes a methodology based on an integrated decision model (IDM) which has been designed to address the shortcomings seen in practice and to improve the evaluation and selection process of public investment projects. The methodology includes not only economic attributes, which are often the sole criteria in current evaluation procedures, but also social, environmental and project support (stakeholders involvement) aspects that are integrated into a single overarching decision model. The suitability of the proposed decision model is tested by applying it to a public investment project in Thailand.

\section{Relevant theories and approaches}

\section{Decision-making process and project evaluation}

The decision-making approach proposed by Bennet and Bennet (2008) characterises a decision as a guess about the expected future. When solving a problem, the situation is estimated, and then anticipated, resulting in a perception about what will happen if one adopts a certain solution. This 'guess' involves many assumptions or alternatives relative to the situation. In public decision-making, where the situation involves wide-ranging problems and places high-level demands on public services, there is no single action that will produce a solution. It requires a continuing and reliable selection process which is built as part of a decision-making process. Harrison (1995) defined the decisionmaking process as a cycle of refining the chosen actions until they achieve the objectives set out in the first place. On this basis, the decision-making function 
should involve the evaluation and selection of alternatives as a distinct stage of the overall process. The decision-making cycle is shown in Figure I.

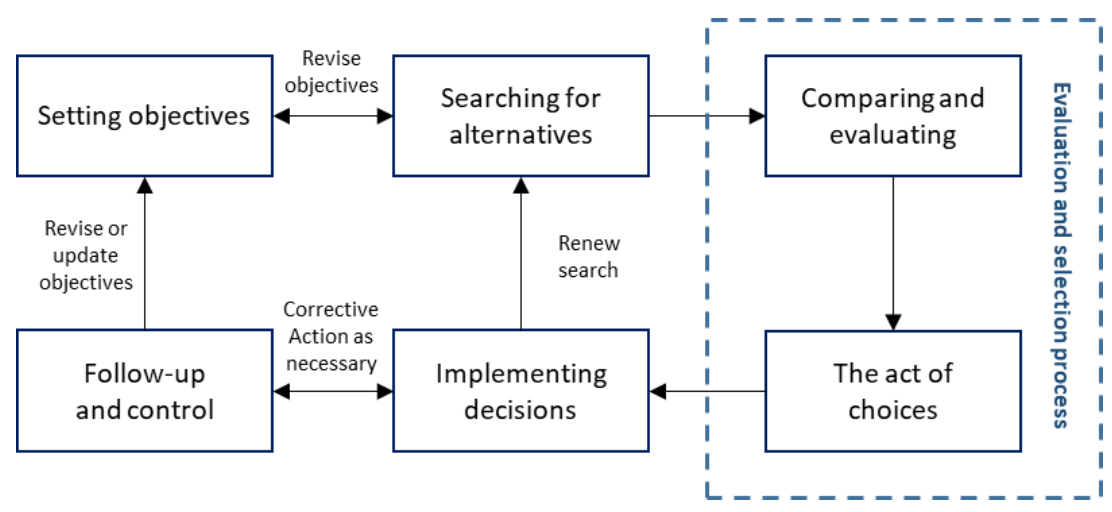

Figure I. The decision making cycle (adapted from Harrison 1995)

While this decision-making approach considers the evaluation of alternatives as one stage of the entire process, in many current practices the evaluation of projects is considered as a process on its own which includes the selection of the best alternative (Mawdesley et al. 2005).

Traditional evaluations of investment projects are concerned with profits and economic returns (Mishan and Quah 2007). They are based on the principle that regardless of the economic environment an organisation faces, it is always prudent to minimise costs and maximise investment in the competing alternatives. Popular techniques that are used to evaluate projects are based on Cost-Benefit Analysis (CBA) principles as a tool to describe and quantify the advantages and disadvantages of a policy in terms of a common monetary unit.

\section{Economic and financial analysis}

The economic and financial analysis of a project is typically based on a comparison of the cash flow of all the costs and benefits resulting from the project's activities (Mahmoodzadeh et al. 2007). Many existing procedures adopt CBA principles to evaluate the relative economic benefits of competing projects. As such, the Net Present Value (NPV), Internal Rate of Return (IRR) and Benefit-Cost Ratio (B/C ratio) continue to remain the major criteria used for this purpose (Walshe and Daffern 1990; Mishan and Quah 2007). NPV is used to measure the efficiency of investment projects (Lee Jr. 2000; Medaglia et al. 2008) and the IRR is used to indicate the maximum economic viability of 
a project for the national economy as a whole (Tsamboulas 2007). The literature, for example Osborne (2010) and Mahmoodzadeh et al. (2007), appears to consider the NPV as superior in ranking alternative investments because it is simpler to calculate and focuses on the absolute wealth created by the project. The IRR is more useful when a selection has to be made within a fixed or limited capital budget.

In public investment projects, the principle of economic analysis is applied to ensure that government funds are efficiently utilised by trading off the funds invested in projects against the anticipated social and environmental benefits from them (see for examples, Gair (2002) and Pearce et al. (2006)). With public awareness of environmental impacts and social issues progressively increasing, research into how multiple values addressing these issues can be incorporated when appraising projects is growing significantly (for example in Raymond et al. (2009); Aksorn and Charoenngam (2015); Haughton et al. (2009)). Regardless of the importance attached to the various criteria (e.g. economic, social and environmental), choosing between alternative investment projects often involves reducing every consideration to a common monetary unit. The use of economic criteria and measures to determine the social and environmental costs and benefits of a project seem to be a common way of assigning monetary values to intangible outcomes. In many public projects, where returns and costs of alternatives cannot be measured in monetary terms, a cost-effectiveness approach - that deals with qualitative returns - is often adopted rather than a CBA (Shaner 1979; Miller and Mustapha 2016). Cost-effectiveness analysis (CEA) is an analytical tool in which the costs and effects of a project are calculated and presented in a ratio of incremental cost to incremental effect in order to capture qualitative outcomes such as mortality and quality of life (Sanders et al. 2016; Dawson 2008). In addition to CBA and CEA approaches, when those making a decision want to consider the effects on the environment, economy and society, a Life Cycle Costing (LCC) assessment can be included to consider an asset's costs (e.g. initial cost, operation and maintenance costs and social and environmental costs) over the life time of that asset (Hoogmartens et al. 2014). One of the main distinctions between LCC and CBA/CEA approaches is that an LCC can be considered as a product-related assessment whereas CBA/CEA assessments mostly focus on projects or policies (Ness et al. 2007) which is the main focus of this paper.

The available literature suggests that economic and financial analyses (CBA and 
CEA) seem to be commonly used for comparing various alternatives based on estimated monetary values (Miller and Mustapha 2016). However, even though converting the benefits of qualitative impacts, such as social and environmental aspects, into a common monetary unit is convenient, it can fail to adequately and completely deal with the actual problems and their relative importance (Munda 2008; Foley and Hamilton 2006; Alkaraan and Northcott 2006). It is not always appropriate to treat the selection of a public investment project as a simple financial investment decision. Careful consideration of non-financial as well as financial criteria should be included in the analysis to deliver the optimal solution (Schniederjans et al. 2004).

\section{Non-financial issues}

In general, public policymaking often focuses on protecting and improving the quality of life (QoL) and wellbeing of populations. A concern widely shared by governments is how to deal with the problem of sub-optimal distribution of income since this affects equality and the overall wellbeing of a country. The solution to this problem usually revolves around prioritising various individuals and sub-groups in a society as well as their differing income levels (Cowell and Gardiner 2000; Adler 2016). Others suggest that social benefit analyses should consider using distributional weights that explicitly connect benefits to relevant social groups and ethical views (Fleurbaey et al. 2013).

Decision-makers and researchers interested in modelling social and environmental intervention projects have sought solutions that are able to measure a project's impacts on society and the environment. It is important in this respect to understand how all the things that matter relate to each other. Different people construct their wellbeing in different contexts and at different times, and it is important to understand what people prioritise and what tradeoffs they are prepared to make between different aspects of wellbeing (Camfield 20I2). The linkage and use of quantitative and qualitative measurements have been explored in a number of research projects (see for example: Camfield (2012); Massam (1999); and Bauer (1966)). A review of social indicators by Casas (20II) concluded that assessing QoL and social impact involves measuring material (such as money and property) and non-material (such as values and feelings) characteristics. As such, more, and different, types of data are necessary for measuring complex social realities. Moreover, describing social situations in terms of realities is imprecise and such measurements can only provide an approximation. 
The above reflection clearly shows the need to move towards measuring social and environmental aspects, as well as how people perceive the impacts on their situation, of proposed investment projects.

\section{Multi-criterialattributes decision analysis}

To cope with the variety of data and complex decisions, a multicriteria or attribute decision analysis (MCDA/MADA) has been suggested in many studies related to public decision-making. The aim of this approach is to combine a wide range of attributes that cannot be evaluated by the measurement of a single evaluative index (see, for example, the studies by Gamboa and Munda (2007), Foxon et al. (2002), Al-Harbi (200I) and Salgado et al. (2009)). It is widely accepted that the significant advantage of this approach is that it satisfies the need to involve a variety of attributes that are measured using different units (e.g. \$, \%, tonne, $\mathrm{km}$.) without having to convert all attributes to a single monetary unit (Adams and Ghaly 2007). MCDA/MADA approaches can also use subjective types of evaluation which are often appropriate when evaluating non-financial issues such as social and environmental impact (Belton and Stewart 2002). If required, the subjective and qualitative evaluations can then be transformed into quantitative values using numerical scales. In this way, a link between qualitative (subjective) and quantitative values (objective) is established, which makes it easier to compare alternatives (Munda 2008).

Many methods have been proposed that adopt the MCDA/MADA approach, and some have been widely used in practice. For example, Saaty (1990) and Dey (2006) have suggested the use of an Analytical Hierarchy Process (AHP) or optimisation models to help solve complex problems by synthesising diverse intuitive considerations of stakeholders into an evaluative result (Widianta et al. 2018). AHP is often used to assist groups of decision-makers to compare and select between projects (Huang et al. 2008). Joshi and Sharma (2016) and Lateef-Ur-Rehman (2013) have applied the Preference Ranking Organization Method for Enrichment Evaluation (PROMOTHEE) to rank various alternative decisions. This approach is a synthesising preference relational system that does not evaluate alternatives in isolation but compares alternatives with each other. It requires decision-makers to provide inputs for a preference function to rank alternatives. Among the other possible methods, Memariani et al. (2009) and Afshari et al. (2010) have suggested using Simple Additive Weighting (SAW), a weighted scores method, to evaluate alternative performances based on relative importance weights. SAW is a classical MCDM/MADM method that is 
simple and forms the basis of most MADM techniques including AHP and PROMOTHEE (Wang 2015; Memariani et al. 2009). The underlying assumption of the SAW method is that attributes are preferentially independent. This means that the contribution of each individual attribute to the final score is independent of all the other attribute values (Yoon and Hwang 1995). In other words, the SAW method is a true-criterion model that does not require any preference functions to be determined by decision-makers and stakeholders and, as such, demands limited input from decision-makers along the entire decision-making process.

The literature review on evaluation and decision-making approaches and techniques shows a lack of consensus on the most appropriate tool to appraise public investment projects. Indeed, one can appreciate that, in order to reach any kind of sensible decision, individuals should not be restrained to the use of one specific model. In reality, when individuals analyse the alternatives that can solve a problem, they usually evaluate them using more than one method or a combination of them. However, traditional practice tends to rely more on CBA, while in developing countries the potential of using multiple methods is often ignored. This usually results in important issues being left out of the evaluation process because they are not considered relevant. Overall, the review highlights the need for integral methods to evaluate and select individual projects. The resulting approach must be able to use procedures from different disciplines but, at the same time, amalgamate these to operate as one unit in order to produce a single evaluation result that integrates all the important issues in a single decision.

\section{The selection of important attributes}

Given the problems with current practice identified in the literature, it is apparent that, in reality, public investment projects in developing countries, including in Thailand, fail to perform satisfactorily despite them receiving good evaluation results in feasibility analyses. Previous investigations have indicated that this under-performance may be due to the type of approach taken during the evaluation stage. Based on the decision-making process in Figure I, the most important step is that the objectives or goals of the decision have to first be established. Usually, the objectives are the basic requirements of the proposed investments, and these can be meaningfully interpreted as several attributes measured by related factors. This implies that the quality of a decision crucially 
depends upon the attributes constructed to allow one to establish relative preferences among alternatives (Bouyssou 1990).

In our research study, to establish which attributes and factors are essential in practice, a set of attributes that were derived from a literature review were presented to 52 experts from various public organisations in Thailand. The experts were selected based on their experience with assessing and managing public investment projects related to important sectors such as water management, transport and agriculture, and their experience in different domains (national, regional, local). They were asked to select the five attributes which they considered the most important given the situation in Thailand. Table I presents the most important attributes and factors as selected by the experts and their corresponding sources in literature.

Table I: Selected attributes and factors for public investment project selection

\begin{tabular}{|c|c|c|c|}
\hline Attributes & Factors & Sources & Descriptions \\
\hline Economic & $\begin{array}{l}\text { Economic viability } \\
\text { (cost-effectiveness/ } \\
\text { cost-benefit/return on } \\
\text { investment) }\end{array}$ & $\begin{array}{l}\text { OECD (20l0); Lee Jr. } \\
\text { (2000); Medaglia, et } \\
\text { al. (2008); } \\
\text { Tsamboulas (2007); } \\
\text { Liu, et al. (2008) }\end{array}$ & $\begin{array}{l}\text { The potential impact of the } \\
\text { proposed project on } \\
\text { economy or economic } \\
\text { activities in the country. }\end{array}$ \\
\hline \multirow{4}{*}{ Social } & $\begin{array}{l}\text { Area-based } \\
\text { requirement/priority }\end{array}$ & $\begin{array}{l}\text { Liu, et al. (2008); } \\
\text { Haughton, et al. } \\
\text { (2009); Raymond, et } \\
\text { al. (2009); Aksorn \& } \\
\text { Charoenngam (20I5) }\end{array}$ & $\begin{array}{l}\text { Addressing the specific } \\
\text { problems and different } \\
\text { needs in the area of the } \\
\text { project. }\end{array}$ \\
\hline & Distributional effects & $\begin{array}{l}\text { Cadena \& Magro } \\
(2015)\end{array}$ & $\begin{array}{l}\text { Groups of people affected } \\
\text { by the project. Who pays? } \\
\text { and who benefits? }\end{array}$ \\
\hline & $\begin{array}{l}\text { Impacts on quality of } \\
\text { life in the target area }\end{array}$ & $\begin{array}{l}\text { Haughton, et al. } \\
(2009)\end{array}$ & $\begin{array}{l}\text { Improving public services } \\
\text { and facilities which directly } \\
\text { affects standard of living of } \\
\text { local people. }\end{array}$ \\
\hline & $\begin{array}{l}\text { Effects on local } \\
\text { employment and } \\
\text { economic activities }\end{array}$ & $\begin{array}{l}\text { Haughton, et al. } \\
\text { (2009); Cadena \& } \\
\text { Magro (20I5); } \\
\text { Garmendia, et al. } \\
(2010)\end{array}$ & $\begin{array}{l}\text { Whether the project will } \\
\text { have influence on } \\
\text { unemployment or people's } \\
\text { income. }\end{array}$ \\
\hline Environmental & $\begin{array}{l}\text { Natural resources and } \\
\text { environmental } \\
\text { disturbance/ impact }\end{array}$ & $\begin{array}{l}\text { Garmendia, et al. } \\
\text { (20I0); Haughton, et } \\
\text { al. (2009); Foxon, et } \\
\text { al. (2002) }\end{array}$ & $\begin{array}{l}\text { Impacts on environmental } \\
\text { quality in an area to foster a } \\
\text { balance between } \\
\text { development and } \\
\text { conservation. This affects } \\
\text { wide ranges of natural } \\
\text { resources, i.e. water, air, } \\
\text { land use, etc. }\end{array}$ \\
\hline $\begin{array}{l}\text { Long-term } \\
\text { support }\end{array}$ & $\begin{array}{l}\text { Community } \\
\text { cooperation and } \\
\text { collaboration }\end{array}$ & $\begin{array}{l}\text { Aksorn \& } \\
\text { Charoenngam (20I5); } \\
\text { Foxon, et al. (2002) }\end{array}$ & $\begin{array}{l}\text { Project working group or } \\
\text { collaboration with local } \\
\text { communities in the area. }\end{array}$ \\
\hline
\end{tabular}


The section below describes the proposed Integrated Decision Model (IDM). IDM has been developed on the basis of the selected attributes, and their proposed measurements as described in this section, and the project evaluation and selection methods discussed in the literature review section of this paper.

\section{The proposed integrated decision model (IDM)}

The underlying principle of the proposed integrated decision model (IDM) and the associated methodology is the recognition that making decisions does not just involve a single set of criteria or attributes determined by economic measures. Therefore, the IDM not only includes an economic model as one of its components, but also focuses on evaluating the impact of investment projects on society and on the environment. Besides considering economic, social and environmental attributes, the model addresses enhancing the longterm implementation of public investment projects by including and measuring project support from the local community and stakeholders, as an important attribute in the evaluation and decision-making process.

Through the application of a number of techniques, the proposed IDM aims to capture the importance of a range of economic and non-economic evaluation factors. This is achieved by integrating various approaches to project evaluation and decision-making within a single model. The evaluation process produces a set of comparative scores for alternative projects with respect to their economic, social and environmental performance and the long-term support for the project. Furthermore, the methodology is designed to be flexible in such a way that users can add additional attributes or replace original routines with new ones relatively easily. Figure 2 shows the IDM methodology for project evaluation and selection.

As indicated in Figure 2, after the initial stage of setting objectives, a project's organisations and decision-makers will need to generate a series of alternatives that could solve the investment problem or improve the existing situation. Once these steps are finalised, the full project evaluation and selection stage can be completed using the IDM methodology. The methodology consists of two fundamental elements: an evaluation part and a selection part. 


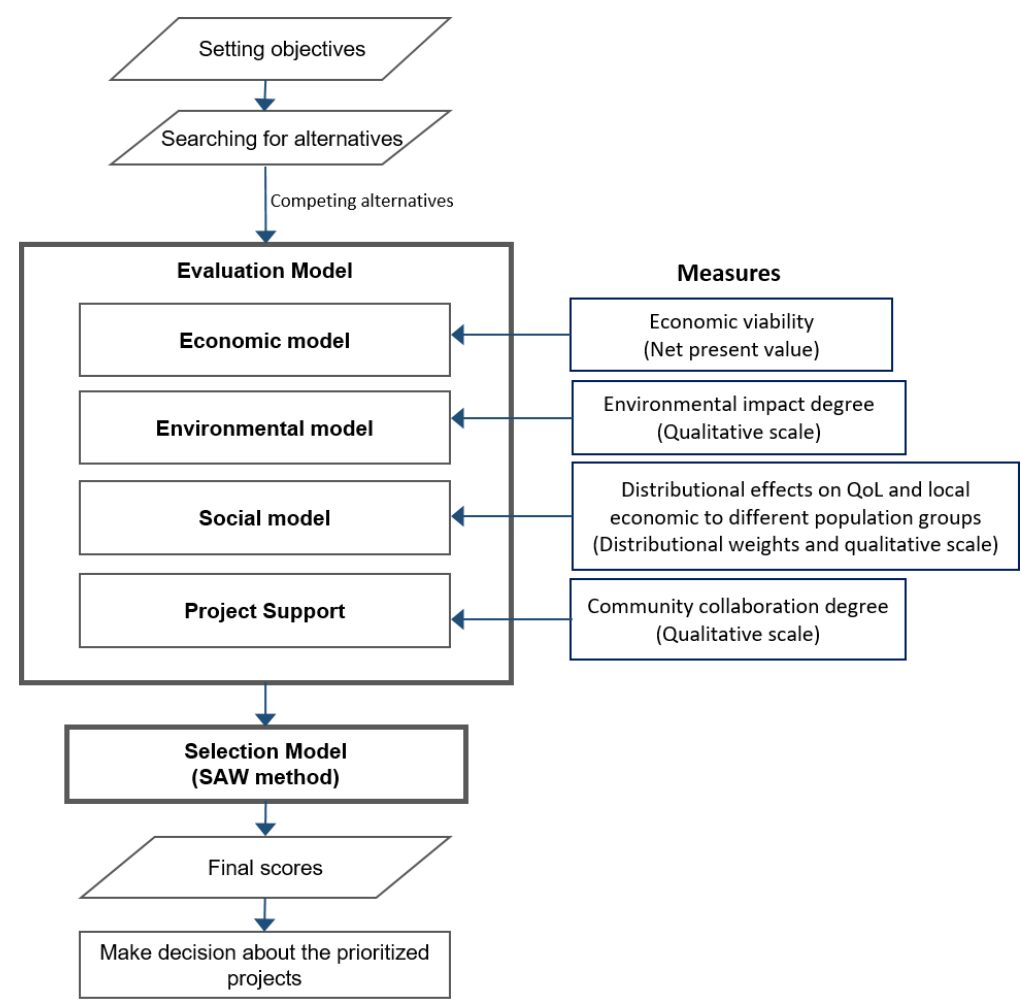

Figure 2. Proposed IDM methodology of project evaluation and selection

\section{Project evaluation element}

This section describes the models used within the methodology to evaluate projects from economic, social and environmental standpoints and in terms of project support.

\section{Economic evaluation}

Based on the selected economic attribute (economic viability), the general purpose of the economic model is to measure the added economic value of a project by comparing its costs and benefits. An NPV approach is suggested because of its simplicity and other advantages, for example that it takes investment size into account, compared to other economic measures. Osborne (2010) and Mahmoodzadeh et al. (2007) both discuss the advantages of using NPV compared to using the Internal Rate of Return (IRR).

NPV can be calculated using Equation (I), see Harberger et al. (1997) and Wetekamp (20II). 


$$
N P V=\sum_{t=0}^{n} \frac{C_{t}}{(1+i)^{t}}
$$

where $C_{t}$ is the project's cash flow (either positive or negative) in time $t$ and $i$ is a discount rate.

When comparing investments, a higher NPV represents a better economic alternative.

In situations where benefits and costs cannot easily be measured, it may be better to adopt a CEA (cost-effectiveness approach) rather than the above cost-benefit approach (see, for example, Shaner (1979)). This is because the CEA approach can cope with qualitative returns and only requires information related to the cost of a certain course of action.

\section{Social evaluation}

Traditionally, public-sector economists see both CBA and CEA as techniques that try to take into account factors that are disregarded by the private sector and also by the public sector in low-income countries (Tang and Phataralaoha 1987; Mishan and Quah 2007). In terms of public-sector investment decisions, it is recognised that applying economic methods to assess social benefits leads to difficulties relating to determining an appropriate social discount rate (Brzozowska 2007; Scarborough 20I I). The discount rate determines the value of future social costs and benefits relative to current ones, and this involves estimating many socioeconomic parameters (Harrison 20I0).

A fundamental element of this social model is that it treats and evaluates costs and benefits in units other than money. This is not straightforward and a new model is developed here in which the benefits and costs are amalgamated into a single measure for comparison purposes. Importantly, this uniform measure does not rely exclusively on monetary factors. This model is developed to respond to the different needs of the local community affected by a project, an area which is not addressed by the current system of public investment project evaluation. It is designed to model the interaction between a project and the local communities in the project area. To do so, the model includes the four main social factors selected by the experts. These are: 
(I) Distributional effects:

(2) Area-based requirement/priority

(3) The economic impact on the population (EI)

(4) The impact on the quality of life (QoL) (i.e. services provided, health, education) of the population affected

The first social factor reflects the position of the affected groups within the national economic spectrum and the extent to which the impact is distributed among these identified groups (Cadena and Magro 2015). The second factor signifies the priority given to the project areas based on the needs of people in those areas (Cowell and Gardiner 2000; Aksorn and Charoenngam 20I5). The definitions of these two factors reflects the intention of the model to give greater weight during the evaluation to groups that have the greatest need for improvements. As such, these two factors can be labelled 'social variables'.

The third and fourth factors identified by the experts reflect the two social impact components that are mainly affected whenever a set of actions is implemented. These components respectively represent the economic and the non-economic (QoL and well-being) impacts of the project.

In the model, the different groups in a project area are distinguished based on the concept of optimal distribution, which involves prioritising the various groups based on their different income levels (Cowell and Gardiner 2000; Adler 2016). As such, the model proposes classifying the population affected by a project into groups based on their income levels. Table 2 presents a proposed classification of population groups, and the priority weights given based on this classification.

Table 2. Classification of population groups based on income levels in a beneficial area

\begin{tabular}{|c|l|c|c|}
\hline $\begin{array}{c}\text { Population } \\
\text { groups }\end{array}$ & \multicolumn{1}{|c|}{$\begin{array}{c}\text { Descriptions } \\
\text { (Income level) }\end{array}$} & $\begin{array}{c}\text { Proportion } \\
\text { (\%) }\end{array}$ & $\begin{array}{c}\text { Priority weights } \\
\text { (\%) }\end{array}$ \\
\hline I & $\begin{array}{l}\text { Very low income/very } \\
\text { poor }\end{array}$ & 30 & 100 \\
\hline 2 & Low income/poor & 30 & 80 \\
\hline 3 & Medium income & 25 & 50 \\
\hline 4 & High income/rich & 10 & 15 \\
\hline 5 & $\begin{array}{l}\text { Very high income/very } \\
\text { rich }\end{array}$ & 5 & 5 \\
\hline & & $\underline{100}$ & \\
\hline
\end{tabular}


The underlying principle is that a population group that can be considered to be disadvantaged (such as very poor people) or has urgent developmental needs can be given a higher priority weighting than others. In other words, higher percentages are given to disadvantaged groups to favour improvements to their situation and to reduce the discrepancies between them and other, better-off, groups.

The usual way of reporting social impact involves evaluating the effect on the entire population irrespective of the number of groups within it. Consequently, in our model, it is necessary to represent every group as a component of the entire population rather than as a complete population in itself. That is, the total population is defined as $100 \%$, and the proportion of the population in each group $(P)$ will be stated as a percentage of the total population.

Measuring the social impacts in this model involves assessing the positive and negative impacts where the investment is made on our third and fourth social factors: the impact on the local economy (EI) and on the quality of life (QoL). The model uses a qualitative five-point scale to assign degrees of impact to each alternative as shown in Table 3. A score of 5 represents a very high positive social improvement and a score of 0 represents a negative social impact. Using the proposed scale helps transform descriptive social impact measurements (very high, low or insignificant impacts etc.) into numerical values.

Table 3. Qualitative scale for social impacts

\begin{tabular}{|l|l|c|}
\hline \multicolumn{1}{|c|}{ Economic impact (EI) } & Repercussions on QoL & Score \\
\hline Significant increase on PCl & Significant improvement & 5 \\
\hline Medium increase on PCl & Medium improvement & 4 \\
\hline Low increase on PCI & Low improvement & 3 \\
\hline Low decrease on PCl & Low depletion & 2 \\
\hline Medium decrease on PCl & Medium depletion & I \\
\hline High decrease on PCl income & Significant depletion & 0 \\
\hline
\end{tabular}

Once the groups have been identified and given a weight in line with Table 2, the social impacts (El and QoL) are determined according to Table 3 for each group independently.

This study proposes using the following two social evaluation formulae (2 and $3)$ to combine the social impacts and variables into a final social score $\left(S C_{i}\right)$ for each alternative project $i$ as follows: 


$$
\begin{gathered}
S C_{i}=\sum_{n=1}^{k} G_{\text {in }} \\
G_{\text {in }}=\left[E I_{\text {in }}+Q o L_{\text {in }}\right] \cdot f_{n} \cdot P_{\text {in }}
\end{gathered}
$$

where:

$G_{i n} \quad$ is the social score of population group $n$ for alternative $i$

$E I_{\text {in }}$ is the local economic income score for population group $n$ for alternative $i$

$Q o L_{\text {in }}$ is the quality of life impact score for population group $n$ for alternative $i$

$f_{n} \quad$ is the priority weighting given to population group $n$

$P_{i n} \quad$ is the proportion of population group $n$ for alternative $i$

The overall social score for a project $\left(S C_{i}\right)$ is obtained by adding the social scores of all population groups affected by the project $\left(G_{i n}\right)$.

For example, if alternative $A$ has a medium positive impact on El and a high positive impact on QoL (scoring 4 and 5 respectively) for population group I, which has a priority weighting of $100 \%$ and makes up $30 \%$ of the total population, the calculated social impact of alternative $A$ on population group $I$ is $(4+5) \times 100 \% \times 30 \%=2.7$. A similar calculation is made for each population group and summing their social impacts provides the overall social score $\left(S C_{i}\right)$ for alternative $A$.

\section{Environmental evaluation}

The factor chosen to assess the environmental attribute is a project's impact/disturbance on natural resources. Typically, environmental impact issues are broad and difficult to model. The frameworks that are often applied in practice, such as EIA/IEE, tend to be detailed in terms of incorporating environmental issues as well as including other factors such as financial and social aspects and public participation. Striving for comprehensiveness by including many issues and aspects in a single assessment results in the 
accumulation of complex information, and this is difficult to use when coming to a decision. Striking a balance between completeness and simplicity of use is seen as one of the challenges in developing an effective and efficient environmental assessment tool (Ding 2008).

The aim in developing the environmental model used in this work is to provide an easy and reliable way to compare the overall environmental impact of various alternative projects. Consequently, a single environmental attribute is suggested that combines the overall impact of a project on both natural resources and on the environment during its construction and implementation. Similar to the scale used in the social model, this model also adopts a qualitative five-point scale that is used to indicate the extent of the environmental impact. Again, this can be either positive or negative. A score of 5 represents a large positive impact on the environment and a score of 0 means that the project has very large negative impact on the environment. This approach allows one to combine various environmental impact issues into a single evaluation index regardless of the type of project or the number of issues in question. The proposed qualitative five-point scale and its description are provided in Table 4.

Table 4. Qualitative scale to indicate an impact degree

\begin{tabular}{|c|c|c|c|c|c|}
\hline \multicolumn{3}{|c|}{ Negative impact } & \multicolumn{3}{c|}{ Positive impact } \\
\hline $\mathrm{H}$ & $\mathrm{M}$ & $\mathrm{L}$ & $\mathrm{L}$ & $\mathrm{M}$ & $\mathrm{H}$ \\
\hline 0 & $\mathrm{I}$ & 2 & 3 & 4 & 5 \\
\hline
\end{tabular}

$\mathrm{H}=$ High, $\mathrm{M}=$ Medium, L=Low

\section{Project support}

The project support aspect, labelled community cooperation and collaboration, is included in an attempt to secure the involvement of the public and local communities. This was selected as an important attribute by the experts as it can help ensure that the project will be supported by these communities and achieve long-term success. Both the literature and practice show that although the benefits of public and local community participation are widely known, the role and capacity of stakeholders and local communities in terms of development activities and influencing decisions remain unknown (Bawole 20 I3; Nadeem and Fischer 20II).

In our proposed model, the participation and engagement of stakeholders and local communities in a project is measured and included in the overall project evaluation. The model uses a qualitative rating scale to represent the degrees 
of support by various stakeholders. A high score represents a strong level of public involvement in and local commitment to the project. The scale levels are assigned values between 0 and 3; 0 representing no support, I weak support, 2 medium support and 3 being strong support.

\section{Project selection element}

Most real-life problems that require decisions will involve the evaluation of multiple objectives and attributes. For this reason, the main assumption of this model is that there is a situation in which a problem requires the consideration of multiple attributes for its solution. The project selection process applied in the IDM uses the SAW model in the MADA approach. SAW is used to rank a set of alternatives to help decision-makers identify the best of the available options (Kabassi and Virvou 2004). This approach is used because it requires limited involvement of the decision-makers and, consistent with the concept of the IDM, the scores for each attribute are independently contributed towards the total final score. The four distinct evaluation results from the economic, social, environmental and project support aspects can then be combined into a single evaluation score.

The steps used in the SAW model as proposed by Yoon and Hwang (1995), Wang (20I5), and Adriyendi (20I5) are adapted for the IDM as follows:

Let $A=\left(a_{1}, a_{2}, \ldots, a_{i}, \ldots, a_{m}\right)$ i.e. a set of alternatives

Let $C=\left(c_{1}, c_{2}, \ldots, c_{j}, \ldots, c_{n}\right)$ the set of relevant attributes

(I) Construct a decision matrix $(m \times n)$.

$$
\begin{array}{cccccc}
d_{11} & d_{12} & \cdots & \cdots & \cdots & d_{1 m} \\
d_{21} & d_{22} & \cdots & \cdots & \cdots & d_{2 m} \\
\vdots & \vdots & \cdots & \cdots & \cdots & \vdots \\
d_{m 1} & d_{m 2} & \cdots & \cdots & \cdots & d_{m n}
\end{array}
$$

where $d_{i j}$ is the attribute value for alternative $i$ with respect to attribute $j$.

(2) Normalise the decision matrix by dividing the performance ratings of each attribute by the maximum performance rating for that attribute (Chakraborty and Yeh 2009). 
The normalized value $r_{i j}$ is obtained by

$$
r_{i j}=\frac{d_{i j}}{d_{j}^{\max }}
$$

where:

$d_{j}^{\text {max }}$ is the maximum performance value among the alternatives for attribute $C_{j}$

and $d_{i j}>0$

For the purpose of simplicity, the results are multiplied by 100 to yield a result expressed as a percentage, making the results easier to understand for non-technical decision analysts.

(3) Assign a weight reflecting relative importance, between 0 and I, to each of the attributes. The sum of all the weights must be $I$.

(4) Calculate a weighted evaluation score for each alternative $A_{i}$ by applying the following formula (Yoon and Hwang 1995; Wang 2015; and Adriyendi 20I5):

$$
S_{i}=\sum_{j=1}^{n} w_{j} \cdot r_{i j}
$$

where:

$S_{i} \quad$ is the final weighted score of alternative $i$

$w_{j} \quad$ is the weight given to attribute $j$

$r_{i j} \quad$ is the normalised score for alternative $i$ on attribute $j$

(5) Rank the alternatives from the highest to lowest scores as a basis for selection. 


\section{Application of the IDM methodology on a real case project}

In this section, the IDM proposed in the previous section is applied to a single case of a public investment project in Thailand. This case was chosen due to the availability of information and the potential support of the project organisation. It also represents typical public investment medium- to large-scale projects that often have to meet specific government statutory requirements.

\section{Project description and current assessment}

Project name: An Irrigation Development Project in Yom River Basin

Project owner: The Royal Irrigation Department (RID), Ministry of Agriculture and Cooperatives

The Yom River Basin is located in the north of Thailand and is one of the main tributaries of the Chao Phraya River, the country's main river. The basin's boundary spreads over II provinces and supports about $9,537 \mathrm{~km}^{2}$ of cultivated area. Annually, the Yom River is subjected to periods of flooding and of severe drought, which impact on people's livelihoods in the area. In an attempt to improve the situation, several water resource management plans have been introduced, one of which was initiated by the RID.

In an early stage of the plan, many alternatives were introduced and initial studies were carried out on each of them by the project analysts and consultants hired by the RID. Many options were examined, and a few were shortlisted during the feasibility study in order to reduce the number of alternatives. Four competing alternatives were chosen for further detailed analysis. The four alternatives are briefly presented in Table 5.

According to the relevant regulations for major projects, an environmental impact assessment (EIA) report has to be made. Even though the project studied was too small to be classed as a major project, its impacts could influence a considerable number of households and a large amount of land in the area. For this reason, it was decided to develop an initial environmental examination (IEE) report, amounting to a brief statement of the EIA of all the alternatives. More details about EIA and IEE procedures can be found in Ogola (2007) and O'Faircheallaigh (20I0). 
Table 5. Alternative projects for the irrigation development of the Yom River Basin

\begin{tabular}{|c|l|l|c|l|}
\hline Alternative & \multicolumn{1}{|c|}{ Name } & \multicolumn{1}{|c|}{ Location } & \multicolumn{2}{c|}{ Direct beneficial area } \\
\hline A & $\begin{array}{l}\text { Mae-Kon } \\
\text { Reservoir }\end{array}$ & $\begin{array}{l}\text { Cho Hae Sub- } \\
\text { District, Mueang } \\
\text { Phrae District }\end{array}$ & $\begin{array}{c}13 \\
\mathrm{~km}^{2}\end{array}$ & $\begin{array}{l}\text { Mueang Phrae and } \\
\text { Sung Men Districts } \\
\text { (Phrae Province) }\end{array}$ \\
\hline B & $\begin{array}{l}\text { Mae-Thun-Noi } \\
\text { Reservoir }\end{array}$ & $\begin{array}{l}\text { Klang Dong Sub- } \\
\text { District, Thung } \\
\text { Saliam District }\end{array}$ & $\begin{array}{l}4.6 \\
\mathrm{~km}^{2}\end{array}$ & $\begin{array}{l}\text { Thung } \\
\text { District } \\
\text { (Sukhothai Province) }\end{array}$ \\
\hline C & $\begin{array}{l}\text { Mae-Teep } \\
\text { Reservoir }\end{array}$ & $\begin{array}{l}\text { Chang Nuea Sub- } \\
\text { District, Mae Mo } \\
\text { District }\end{array}$ & $\begin{array}{l}\text { Mae Mo and Ngao } \\
\mathrm{km}^{2}\end{array}$ & $\begin{array}{l}\text { Districts } \\
\text { (Lampang Province) }\end{array}$ \\
\hline D & $\begin{array}{l}\text { Piang Mok Sub- } \\
\text { District, Thoen } \\
\text { District }\end{array}$ & $\begin{array}{l}11.2 \\
\mathrm{~km}^{2}\end{array}$ & $\begin{array}{l}\text { Thoen District } \\
\text { (Lampang Province) }\end{array}$ \\
\hline
\end{tabular}

The main results of the IEE report were presented in a descriptive form broken down into several sections. The descriptions included project impacts (for example on the environment, transport, agriculture, fishery and the quality of life), reports on public hearings about the project with local communities as well as preventive and mitigating solutions. There was also a quantitative assessment in the IEE of the project's benefits in monetary terms. A CBA approach was used to assess economic benefits which included NPV, IRR and $B / C$ ratios. The best alternative based on this assessment was alternative $C$ because it had the highest IRR. This conclusion excluded consideration of other important aspects for a public investment project.

\section{Application of the proposed IDM}

The application of the proposed IDM to this case project started in the project evaluation stage. Some data for each alternative were derived from the IEE. For some parameters where data were not available in the IEE, information from other external sources was used as indicated where appropriate.

\section{Project evaluation}

The attributes representing the economic, social, environmental and project support aspects are denoted as $C_{1}, C_{2}, C_{3}, C_{4}$ respectively. The evaluation of each attribute is illustrated and described below:

\section{(I) Economic $\left(C_{l}\right)$}

The IEE already contained economic cost and benefit evaluations in terms of the NPV, IRR and B/C Ratio, and therefore there was no need to carry out 
further economic analyses. Table 6 presents the current economic assessments of each alternative.

Table 6. Economic assessments of each alternative

\begin{tabular}{|c|c|c|c|c|}
\hline \multirow{2}{*}{ Attribute } & \multicolumn{4}{|c|}{ Alternative } \\
\cline { 2 - 5 } & A & B & C & D \\
\hline NPV (Million THB)* & 134.32 & 20.54 & 87.25 & 18.82 \\
\hline IRR (\%) & 10.77 & 9.16 & 12.26 & 10.57 \\
\hline B/C Ratio & 13.2 & 1.13 & 1.23 & 1.06 \\
\hline
\end{tabular}

*THB = Thai Baht

Given the earlier explained advantages of NPV over other economic criteria in the economic component of the IDM, the NPV will be used when comparing the competing alternatives in the selection stage.

(2) Social $\left(C_{2}\right)$

Classification of population groups in the project area. External data were used to identify and classify population groups affected by the project. Here, incomelevel data published by NSO (National Statistical Office Thailand 2006) were used. The income levels were layered over a map of the Yom River Basin area to produce a poverty map representing the percentages of low-income households in various districts within the project area. The percentages of lowincome households were divided into five levels, ranging from the lowest $(<5 \%)$ to the highest ( $>35 \%$ ), as shown in Figure 3 . That is, districts populated by more poor people have higher percentages than other areas. Figure 3 shows the locations and the categorised population groups in the alternatives' areas based on the poverty map and the Yom River Basin boundary.

Accordingly, the proportions of the population are estimated in percentages and the total percentage of each area is 100, representing all households affected by each alternative. Table 7 illustrates the different population compositions of all the alternatives and the priority weights based on the proposed social weights in Table 2. 


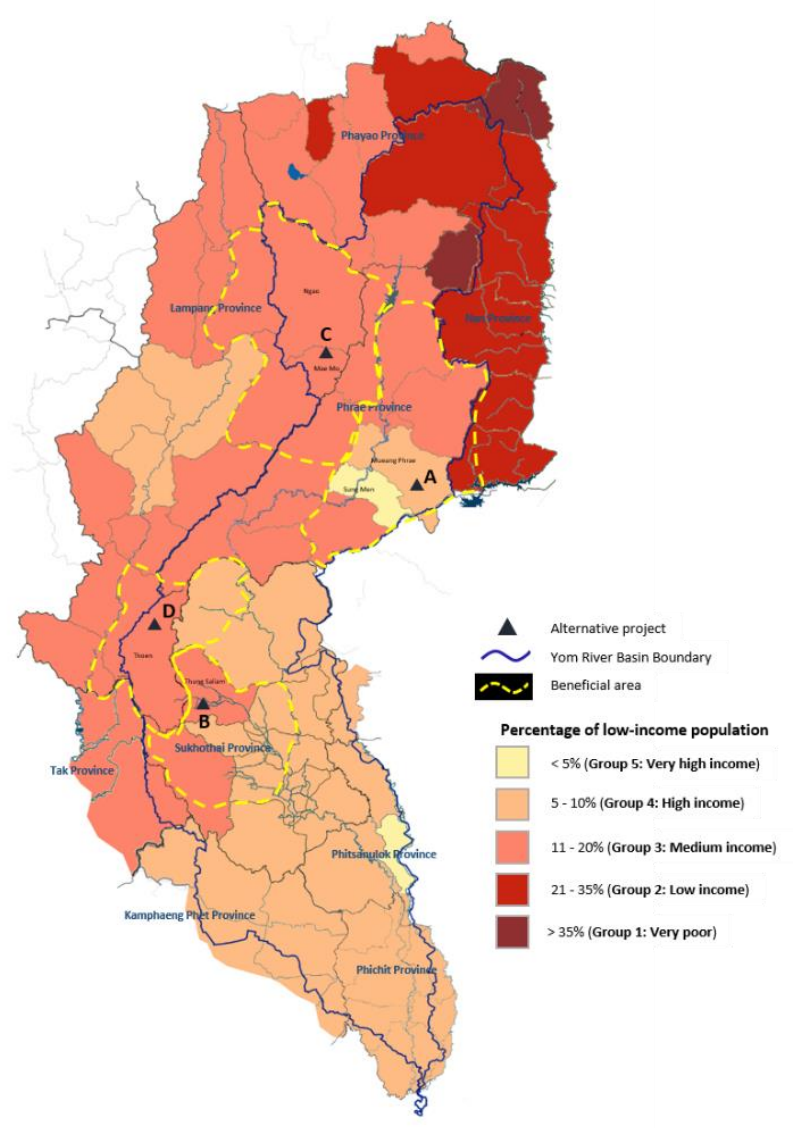

Figure 3. Locations of alternatives and population groups in the Yom River Basin

Table 7. Population compositions of all alternatives and the priority weights

\begin{tabular}{|c|l|c|c|c|c|c|}
\hline \multirow{2}{*}{$\begin{array}{c}\text { Population } \\
\text { group }\end{array}$} & Description & \multirow{2}{*}{$\begin{array}{c}\text { Priority } \\
\text { weight } \\
\text { (\%) }\end{array}$} & \multicolumn{3}{|c|}{ Proportion of population (\%) } \\
\cline { 5 - 8 } & & A & B & C & D \\
\hline I & $\begin{array}{l}\text { Very low } \\
\text { income/very poor }\end{array}$ & 100 & - & - & - & - \\
\hline 2 & Low income/poor & 80 & 20 & - & - & - \\
\hline 3 & Medium income & 60 & 45 & 50 & 100 & 65 \\
\hline 4 & High income/rich & 20 & 20 & 50 & - & 35 \\
\hline 5 & $\begin{array}{l}\text { Very high } \\
\text { income/very rich }\end{array}$ & 5 & 15 & - & - & - \\
\hline
\end{tabular}


The social impacts. The social impacts of a project include two social factors. The first is the economic impacts (EI) of the project related to local income improvements due to improved crop yields and increased employment. The second factor is the impact on the QoL. This covers several issues that affect the communities as a consequence of the new reservoir such as water usability, irrigation system and landscape improvements. The authority which carried out the original evaluation did not have any information that could be used to give values to the social measure adopted in the IDM. Therefore, as an experiment, the researchers assumed that people living in different locations would be subjected to varying degrees of impact. The population groups living closer to a project location would perceive more benefits than those living farther away. The social impacts of the two variables on the different population groups for each alternative are indicated in Table 8 using the rating scale proposed in Table 3.

Table 8. Social impacts on the affected groups of each alternative

\begin{tabular}{|c|c|c|c|c|c|c|c|c|}
\hline \multirow{2}{*}{$\begin{array}{c}\text { Population } \\
\text { group }\end{array}$} & \multicolumn{3}{|c|}{ Economic impacts } & \multicolumn{4}{c|}{ QoL impacts } \\
\cline { 2 - 10 } & A & B & C & D & A & B & C & D \\
\hline I & 0 & 0 & 0 & 0 & 0 & 0 & 0 & 0 \\
\hline 2 & 3 & 0 & 0 & 0 & 4 & 0 & 0 & 0 \\
\hline 3 & 3 & 5 & 5 & 5 & 4 & 5 & 5 & 5 \\
\hline 4 & 5 & 4 & 0 & 4 & 5 & 4 & 0 & 4 \\
\hline 5 & 5 & 0 & 0 & 0 & 5 & 0 & 0 & 0 \\
\hline
\end{tabular}

The final social score for each alternative is calculated using equations (2) and (3) with the El and QoL scores obtained in Table 8 and the priority weights and proportions of population groups in Table 7 . The final social scores for all the alternatives are shown in Table 9.

Table 9. Final social scores for all alternatives

\begin{tabular}{|c|c|c|c|c|}
\hline \multirow{2}{*}{ Population group } & \multicolumn{4}{|c|}{ Alternative } \\
\cline { 2 - 5 } & A & B & C & D \\
\hline I & 0 & 0 & 0 & 0 \\
\hline 2 & 1.12 & 0 & 0 & 0 \\
\hline 3 & 1.89 & 3 & 6 & 3.9 \\
\hline 4 & 0.4 & 0.8 & 0 & 0.56 \\
\hline 5 & 0.075 & 0 & 0 & 0 \\
\hline Total social scores & $\mathbf{3 . 4 9}$ & $\mathbf{3 . 8 0}$ & $\mathbf{6}$ & $\mathbf{4 . 4 6}$ \\
\hline
\end{tabular}


(3) Environmental $\left(C_{3}\right)$

The original environmental assessment in this project covered eight important issues in two phases of the project: the construction phase (short-term impacts) and the implementation phase (long-term impacts). The existing assessment was in a descriptive format but conclusions were presented for each issue, indicating either high, medium or low positive or negative impacts. These assessments were transformed into a measurable format using the qualitative rating scale proposed in Table 4. The assessments of the various alternative projects based on the IDM are shown in Table 10.

Table I0. Environmental assessment based on the qualitative scale

\begin{tabular}{|c|c|c|c|c|c|c|c|c|}
\hline Alternative & \multicolumn{2}{|c|}{$\mathbf{A}$} & \multicolumn{2}{|c|}{ B } & \multicolumn{2}{|c|}{ C } & \multicolumn{2}{|c|}{ D } \\
\hline $\begin{array}{l}\text { Environmental } \\
\text { Issue }\end{array}$ & $\begin{array}{l}\text { Short- } \\
\text { term }\end{array}$ & $\begin{array}{l}\text { Long- } \\
\text { term }\end{array}$ & $\begin{array}{c}\text { Short- } \\
\text { term }\end{array}$ & $\begin{array}{l}\text { Long- } \\
\text { term }\end{array}$ & $\begin{array}{l}\text { Short- } \\
\text { term }\end{array}$ & $\begin{array}{l}\text { Long- } \\
\text { term }\end{array}$ & $\begin{array}{c}\text { Short- } \\
\text { term }\end{array}$ & $\begin{array}{l}\text { Long- } \\
\text { term }\end{array}$ \\
\hline E I & 2 & - & 2 & - & 2 & - & 2 & - \\
\hline E2 & 2 & 3 & 2 & 4 & 2 & 4 & 2 & 4 \\
\hline E3 & 2 & 2 & 2 & 2 & 2 & 2 & 2 & 2 \\
\hline E4 & - & 3* & - & 3 & - & 3 & - & 3 \\
\hline E5 & 2 & 2 & 2 & 2 & 2 & 2 & 2 & 2 \\
\hline E6 & 2 & I & 2 & 2 & 2 & I & 2 & I \\
\hline E7 & 2 & - & 2 & - & 2 & - & 2 & - \\
\hline E8 & - & 4 & - & 4 & - & 4 & - & 4 \\
\hline Total score & 12 & 15 & 12 & 17 & 12 & 16 & 12 & 16 \\
\hline \multicolumn{5}{|c|}{$\begin{array}{l}\text { Environmental impacts on: } \\
\text { EI = Topographical change } \\
\text { E2 = Ground water hydrology quality } \\
\text { E3 = Ground water quality } \\
\text { E4 = Underground water quality }\end{array}$} & \multicolumn{4}{|c|}{$\begin{array}{l}\text { E5 }=\text { Soil quality } \\
\text { E6 }=\text { Water ecology } \\
\text { E7 }=\text { Woodland } \\
\text { E8 }=\text { Wild animals }\end{array}$} \\
\hline
\end{tabular}

As Table 10 shows, all the alternative projects have the same short-term score (12), implying that there are no preferred alternatives in terms of their short-term environmental impacts. However, there are differences related to their long-term environmental impacts, on the basis of which a selection decision can be made.

(4) Project Support $\left(C_{4}\right)$

Available information based on the IEE report was used to assess the IDM's project support aspect. The information available showed that all the alternatives had been through a shared public participation exercise controlled by government officials which included attitude surveys based on gathering residents' opinions about the project. In general, the outcomes of such 
participation exercises are rarely used in the decision-making process because of their descriptive nature. They tend to be more of a rubber-stamping procedure to demonstrate a semblance of public participation, and their feedback and opinions are not meaningfully considered (Choguill 1996).

For the purpose of evaluating this attribute for application in the IDM, the available information was considered and, as it appeared that all the alternatives had a fair level of public support, they were therefore all assigned a score of 2 .

\section{Project selection}

Both the initial and the normalised scores in the decision-making matrix produced for this project using the IDM are shown in Table II.

Table II. MADM matrix and the normalized scores (NS) of all alternatives

\begin{tabular}{|c|c|c|c|c|c|c|c|c|}
\hline \multirow{2}{*}{ Alt } & \multicolumn{2}{|c|}{$\boldsymbol{C}_{\mathbf{1}}$} & \multicolumn{2}{c|}{$\boldsymbol{C}_{\mathbf{2}}$} & \multicolumn{2}{c|}{$\boldsymbol{C}_{\mathbf{3}}$} & \multicolumn{2}{c|}{$\boldsymbol{C}_{\mathbf{4}}$} \\
\cline { 2 - 10 } & NPV* & NS** & $\begin{array}{c}\text { Social } \\
\text { score }\end{array}$ & NS** & $\begin{array}{c}\text { Environmental } \\
\text { impact }\end{array}$ & NS** & $\begin{array}{c}\text { Support } \\
\text { degree }\end{array}$ & NS** \\
\hline A & 134.32 & 100 & 3.49 & 58.08 & 15 & 88 & 2 & 100 \\
\hline B & 20.54 & 15.29 & 3.80 & 63.33 & 17 & 100 & 2 & 100 \\
\hline C & 87.25 & 64.96 & 6 & 100 & 16 & 94 & 2 & 100 \\
\hline D & 18.82 & 14.01 & 4.46 & 74.33 & 16 & 94 & 2 & 100 \\
\hline
\end{tabular}

$*$ Unit $=$ Million THB

**NS $=$ Normalised score

Importance weights were assigned to the economic, social, environmental and project support attributes by a decision-maker from the RID based on the overarching project objective which is to improve the local people's water situation and environment, and are presented in the following weight vector:

$$
W=[0.2,0.3,0.3,0.2]=1
$$

The final weighted scores are calculated using formula (5) as shown in Table 12. The alternatives are ranked from highest to lowest based on the final weighted scores as indicated in the right-hand column of Table 12 .

Table 12. Evaluation scores for all alternatives

\begin{tabular}{|c|c|c|c|c|c|c|}
\hline Alternative & $\boldsymbol{C}_{\boldsymbol{I}}$ & $\boldsymbol{C}_{\mathbf{2}}$ & $\boldsymbol{C}_{\boldsymbol{3}}$ & $\boldsymbol{C}_{\boldsymbol{4}}$ & $\begin{array}{c}\text { Weighted } \\
\text { scores }\end{array}$ & Rank \\
\hline A & 20 & 17.42 & 26.40 & 20 & 83.82 & 2 \\
\hline B & 3.06 & 19 & 30 & 20 & 72.06 & 4 \\
\hline C & 12.99 & 30 & 28.20 & 20 & 91.19 & $\mathrm{I}$ \\
\hline D & 2.8 & 22.30 & 28.20 & 20 & 73.30 & 3 \\
\hline
\end{tabular}


The results show that alternative $C$ has the highest score (91.19), indicating that it comes closest to satisfying all the criteria. Alternative $A$ comes in second place with a slightly lower score (83.82), followed by alternatives $D$ (73.30) and $B$ (72.06).

\section{Assessment of the IDM for practical use}

To assess the proposed conceptual IDM methodology, it was presented along with its initial application to several expert panels at relevant local and central agencies in Thailand. The aim was to assess the proposed IDM in terms of three aspects: I) Ease of use, 2) Appropriateness of factors used and 3) Adaptability and flexibility. In total, 30 experts provided their opinions on the methodology by answering questions using a four-point scale ranging from 'disagree' to 'strongly agree'. The overall results from this assessment by the experts are shown in Figure 4.

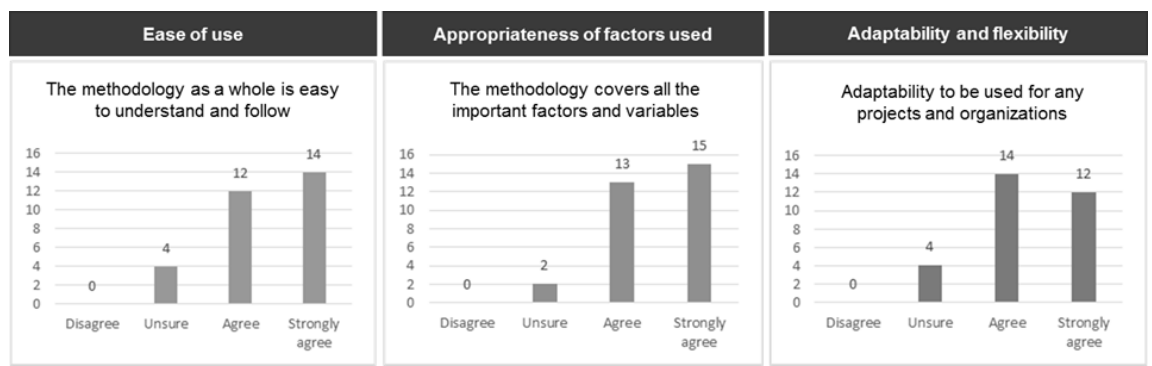

Figure 4: The assessment results of the conceptual methodology and the decision model

The results from this overall assessment indicate that the majority of the experts were positive about most of the aspects of the IDM. Although the assessment implies that the IDM is useful and practical for use in the evaluation and selection of public investment projects in Thailand, there were additional comments and suggestions for further improvement that should be considered. The overall comments were largely related to the calculations used in the IDM, such as the NPV calculation, which were unfamiliar to some of them. They also recommended demonstrating the methodology with a range of real project cases to ensure that the factors used are appropriate in all project contexts. 


\section{Discussion}

The integrated decision model (IDM) proposed in this paper is aimed at improving the current project evaluation and selection process by integrating various approaches that address aspects relevant when evaluating a public investment project. The IDM methodology was tested by applying it to a structural irrigation development project in Thailand and was assessed by experts from various organisations. The application and the experts' assessment indicate the effectiveness of the developed methodology in terms of ease of use, adaptability and flexibility, as well as an improvement over the current evaluation and selection process.

The application and experts' assessment have also indicated the usefulness of the IDM by offering a substantial improvement on the current procedure by providing greater insight into how the alternatives impact on social and environmental issues. Hence the IDM approach can provide better information in a useable form to ease a more informed decision when seeking to select the most effective solution. The original assessment in the project studied simply used IRR to compare alternatives on an economic basis. However, as Table 6 shows, an economic assessment based on NPV (as in the IDM) can provide a different optimum solution to one based on the IRR. Hence, even a simple economic evaluation can produce different outcomes (IRR: alternative C - NPV alternative A). Using NPV provides a clearer result that reflects the size of investment capital in monetary unit to be compared.

The application has also highlighted that the area affected by the Yom River Basin, that encroaches several provinces, is very large. The size of the project explains the complexity of the communities affected by the proposed project's alternatives. The use of population compositions based on income levels in the social model helps to manage such complexity and provides a clearer picture of the possible interaction between each alternative and the community groups affected by it. This interaction is represented in the final social scores. Alternative $C$ produces the highest social score due to the fact that this alternative positively affects the largest of the poorer communities which leads to it being assigned a higher priority weight in the model.

The methodology's use of a rating scale can also enhance the usual environmental assessment and public participation in an IEE report. The current IEE approach is primarily descriptive and this makes it difficult to use in a 
decision-making process. In our case study, various issues in the environmental assessment were summarised and transformed using the proposed scale into a single matrix. The extent of stakeholder and local community participation in the project is determined by measuring their support level. This has made it simpler and easier to complete the analysis and compare alternative projects.

The final decision on the best alternative to select is then made using the SAW model. Currently in Thailand, project evaluation and selection is mainly carried out by evaluators or an organisation's project analysts, with executive decisionmakers scarcely involved. The IDM case has demonstrated the model's suitability as an approach that can allow decision-makers to become involved in the later stages with their preferences influencing the attributes' weights to be applied in the SAW model.

Comparing the outcomes from the original assessment with the results produced by the IDM, one will observe that both conclude that alternative $C$ is the best option. In the original assessment this was seen as the best based solely on an economic (IRR) calculation. In the IDM approach, alterative $C$ came second in the economic (NPV) assessment, but its high social and environmental scores meant it came top overall. As such, the fact that alternative $C$ came top in both appraisals is simply coincidence. The project support attribute had no effect on the final score since all the alternatives were given the same performance score for this attribute. This weakness in the approach is discussed in more detail below.

Even if the developed IDM results in the same preferred choice as a simple economic appraisal, the new approach nevertheless provides the decisionmaker with additional information that they can use to make the investment decision transparent. While the IDM uses existing evaluation and selection techniques (e.g. NPV, SAW, qualitative measurements), its added value is that it integrates these into a single decision model that a decision-maker can use to see the effect on the final decision of making changes in one attribute. Further, the methodology does not attempt to convert all the attribute values into financial equivalents but leaves them in their own units and then converts the values into unitless scores for the final comparison. Perhaps the most useful novel approach in the methodology is the way social aspects are evaluated. The paper describes how the IDM approach models the social variables and the impacts on the local community, thereby allowing the decision-makers to 
examine the interactions between the project and the conditions faced by the community.

Furthermore, the IDM can enhance the descriptive nature of a previous EIA/IEE to provide a clearer, more meaningful result. If a formal EIA/IEE is carried out after a choice is made based on the IDM, it can then be used to recheck the IDM results using more reliable information for each evaluation aspect.

Although incorporating information from an EIA/IEE in the evaluation process is suggested and indeed demonstrated in this paper, the ranking of impacts could prove problematic since very significant social and environmental impacts on critical species and habitats would be diluted by attributing values to all the factors. Here we would suggest that the experts tasked with carrying out the EIA/IEE process should take serious note of the investment objectives and work closely with project evaluators in order to examine how these critical issues can be adequately addressed.

In our example study, the project support attribute had no influence because all the possible projects were given the same score. Consequently, thought needs to be given to how to improve the existing way of involving stakeholders and communities. This could result in both more meaningful participation as well as a more nuanced assessment of the extent of community support. There are various participatory approaches that could be applied to address this issue. For example, one could use participatory MCDA in which values for different parties are constructed and included in a decision (see, for example, Scott 2005; Salgado et al. 2009); or apply the Social License to Operate (SLO) in participatory activities in order to ensure the acceptance or approval of the indigenous people in a certain area (see, for example, Demuijnck and Fasterling 2016; Wilburn and Wilburn 20II).

\section{Conclusion}

Current evaluation and selection procedures for public investment projects in developing countries are primarily focused on economic benefits and thus ignore other important aspects. In this paper, an integrated decision model (IDM) and a stepwise approach are proposed to improve the current process by integrating various techniques that address not only economic attributes but also social, environmental and project support attributes into one decision 
model. The application of the IDM on an irrigation development project for the Yom River Basin in Thailand has demonstrated its effectiveness in improving the project selection process through a more systematic and transparent approach. The importance of societal and of environmental impacts have been incorporated within the decision-making model and thus it considers the possible interactions between each alternative and the community groups affected by it. Moreover, the IDM has been supported by several experts who evaluated it as easy to use and adaptable. It provides decision-makers with insights into all the relevant impacts of a proposed project.

Nevertheless, to date, the IDM has only been tested on a single case in the construction field in Thailand. As such, further applications of the IDM to other important sectors, such as energy, education and healthcare, and other countries would be useful in validating its applicability.

Further, if necessary, possible extensions to the social model, especially where it concerns QoL could be considered to identify other social impacts, such as cultural and traditional environment impacts, that might occur and should then be carefully assessed in the model. A sensitivity analysis is also recommended to further test the robustness of the results produced by the IDM. The weights subjectively assigned by decision-makers could be tested in a sensitivity analysis to boost the confidence in and credibility of the chosen project. 
212 | 


\section{Bibliography}

Abdullah, N., \& Nordin, S. (2008). The theory-practice gap of project appraisals. Journal Pengurusan (UKM Journal of Management), 27, 85- 104.

Adams, M., \& Ghaly, A. (2007). The foundations of a multi-criteria evaluation methodology for assessing sustainability. International Journal of Sustainable Development \& World Ecology, 14, 437-449.

Adler, M. D. (2016). Benefit-cost analysis and distributional weights: An overview. Review of Environmental Economics and Policy, 264-285.

Adriyendi, A. (20I5). Multi-attribute decision making using simple additive weighting and weighted product in food choice. International Journal of Information Engineering and Electronic Business, 6, 8-14.

Afshari, A., Mojahed, M., \& Yusuff, R. M. (2010). Simple Additive Weighting approach to personnel selection problem. International Journal of Innovation, Management and Technology, I, No.5, 5II-5I5.

Aksorn, P., \& Charoenngam, C. (2015). Sustainability factors affecting local infrastructure project: The case of water resource, water supply, and local market projects in Thai communities. Facilities, 33, II9-143.

Al-Harbi, K. M.-S. (200I). Application of the AHP in project management. International Journal of Project Management, 19, 19-27.

Ali, G. S. (2017). Post Completion Sustainability of Ethiopian Railway Project: The Case of Addis Ababa Light Rail Transit Project (AALRTP). Management, 7(I), 7-28.

Alkaraan, F., \& Northcott, D. (2006). Strategic capital investment decision-making: A role for emergent analysis tools? A study of practice in large UK manufacturing companies. The British Accounting Review, 38, I49-173.

Alkire, S., \& Santos, M. E. (20I I). Acute Multidimensional Poverty: A New Index for Developing Countries. Proceedings of the German Development Economics Conference, No.3. Berlin.

Arnstein, S. R. (1969). A Ladder of Citizen Participation. Journal of the American Institute of Planners, 216-224.

Au, T., \& Au, T. (1992). Engineering Economics for Capital Investment Analysis (2nd ed.). New Jersey, USA: Prentice Hall.

Baber, W. F., \& Bartlett, R. V. (2005). Deliberative Environmental Politics: Democracy and Ecological Rationality. Cambridge: MA: MIT Press.

Baer, W. (2008). The Brazilian economy: Growth and development (6th ed.). USA: Lynne Rienner.

Bartlett, R. V. (1990). Ecological reason in administration: Environmental impact assessment and administrative theory. Managing Leviathan: Environmental politics and the administrative state, 81-96. 
Bauer, R. (1966). Social indicators. Cambridge: The M.I.T.

Bawole, J. N. (20I3). Public hearing or 'hearing public'? An evaluation of the participation of local stakeholders in environmental impact assessment of Ghana's Jubilee oil fields. Environmental Management, 52, 385-397.

Belton, V., \& Stewart, T. J. (2002). Multiple Criteria Decision Analysis: An Integrated Approach. Boston, Dordrecht, London: Kluwer Academic Publisher.

Bennet, A., \& Bennet, D. (2008). Foundations of Decision Support Systems. In Burstein, F. \& Holsapple, C. W. (Eds), Handbook on Decision Support Systems I: Basic Themes (pp. 3-20). Berlin Heidelberg: Springer-Verlag.

Besley, T., \& Coate, S. (2003). Centralized versus decentralized provision of local public goods: a political economy approach. Journal of Public Economics, 87, 26I I2637.

Biezma, M., \& San Cristobal, J. (2006). Investment criteria for the selection of cogeneration plants-a state of the art review. Applied Thermal Engineering, 26, 583-588.

Blanchard, B. S., \& Fabrycky, W. J. (20I I). Systems Engineering and Analysis (5th ed.). New Jersy, USA: Prentice Hall.

Boardman, A. E., Greenberg, D. H., Vining, A., \& Weimer, D. L. (2017). Cost-Benefit Analysis: Concepts and Practice. Cambridge University Press.

Bond, A., Morrison-Saunders, A., \& Pope, J. (20I2). Sustainability assessment: the state of the art. Impact Assessment and Project Appraisal, 30, 53-62.

Bouyssou, D. (1990). Building criteria: A prerequisite for MCDA. In Costa, C. A. (Ed), Readings in multiple criteria decision aid (pp. 58-80). Berlin Heidelberg: Springer.

Bragg, S. (2018, December 03). Payback method: Payback period formula. Retrieved from Accounting Tools: https://www.accountingtools.com/articles/2017/5/I7/payback-method-paybackperiod-formula

Brock, K. (1999). It's not only wealth that matters - It's peace of mind too: A review of participatory work on poverty and ill-being. Washington, DC: World Bank.

Brzozowska, K. (2007). Cost-Benefit Analysis in Public Project Appraisal. Engineering Economics, 3(53), 78-83.

Bunn, D. (1984). Applied Decision Analysis. USA: McGraw Hill Inc.

Cabanac, M. (1992). Pleasure: the common currency. Journal of Theoretical Biology, I55, 173-200.

Cadena, P. C., \& Magro, J. M. (20I5). Setting the weights of sustainability criteria for the appraisal of transport projects. Transport, 30(3), 298-306.

Camfield, L. (20I2). Quality of life in developing countries. In Land, K. C., Michalos, A. C. \& Sirgy, M. (Eds), Handbook of Social Indicators and Quality of Life Research (pp. 399-432). Springer Science+Business Media B.V. 
Casas, F. (20I I). Subjective social indicators and child and adolescent well-being. Child Indicators Research, 4(4), 555-575.

Chakraborty, S., \& Yeh, C.-H. (2009). A simulation comparison of normalization procedures for TOPSIS. 2009 International Conference on Computers and Industrial Engineering. Troyes, France: IEEE.

Charuvichaipong, C., \& Sajor, E. (2006). Promoting waste separation for recycling and local governance in Thailand. Habitat International, 30(3), 579-594.

Cho, W., \& Shaw, M. J. (2013, November). Portfolio Selection Model for Enhancing Information Technology Synergy. IEEE Transactions on Engineering Management, 60(4), 739-749.

Choguill, M. B. (1996). A Ladder of Community Participation for Underdeveloped Countries. Habitat International, 20(3), $431-444$.

Costanza, R., Kubiszewski, I., Giovannini, E., Lovins, H., McGlade, J., Pickett, K., Ragnarsdottir, K. V., Roberts, D., Vogli, R. \& Wilkinson, R. (20I4). Time to leave GDP behind. Nature, 505, 283-285.

Cowell, F. A., \& Gardiner, K. (2000). Welfare Weights. London: Office of Fair Trading.

Dabla-Norris, E., Brumby, J., Kyobe, A., Mills, Z., \& Papageorgiou, C. (20I2). Investing in public investment: an index of public investment efficiency. Journal of Economic Growth, I7(3), 235-266.

Dawson, G. F. (2008). Economic Analysis. In Easy Interpretation of Biostatistics (pp. I59162). United State of America: SAUNDERS Elsevier.

Deng, H., Yeh, C.-H., \& Willis, R. (2000). Inter-company comparison using modified TOPSIS with objective weights. Computers \& Operations Research, 27(10), 963973.

Deolalikar, A.B. (2002). Poverty, growth, and inequality in Thailand. Manila: Asian Development Bank.

Dey, P. K. (2006). Integrated project evaluation and selection using multiple-attribute decision-making technique. International Journal of Production Economics, 103, 90-103.

Diduck, A., \& Sinclair, A. (2002). Public involvement in environmental assessment: the case of the nonparticipant. Environmental Management, 29, 578-588.

Ding, G. K. (2008). Sustainable construction - The role of environmental assessment tools. Journal of Environmental Management, 45 I-464.

Dobes, L., Leung, J., \& Argyrous, G. (2016). Social discount rates. In Social Cost-Benefit Analysis in Australia and New Zealand: The State of Current Practice and What needs to be Done (Pp. I77-184). ANU Press.

Doya, K., \& Shadlen, M. N. (20I2). Decision making: Editorial overview. Current Opinion in Neurobiology, 22, 9। I-9। 3. 
Einhorn, H. J., \& Hogarth, R. M. (1988). Behavioral Decision Theory: Processes of Judgment and Choice. In Bell D. E., Raiffa H., \& Tversky A. (Eds), Decision Making: Descriptive, Normative, and Prescriptive Interactions (pp. I I3-I46). Cambridge: Cambridge University Press.

Elbing, A. O. (1978). Behavioral Decisions in Organizations (2nd ed.). USA: Scott Foresman \& Co.

European Commission. (2015). Guide to cost-benefit analysis of investment projects: Econominc appraisal tool for Cohesion Policy 20 I 4-2020. Luxembourg: European Union.

Fan, S., Jitsuchon, S., \& Methakunnavut, N. (2004). The importance of public investment for reducing rural poverty in middle-income countries: The case of Thailand.

Development Strategy and Governance Devision. USA: International Food Policy Research Institute.

Fang, Z., \& Sakellariou, C. (20I3). Evolution of Urban-rural Living Standards Inequality in Thailand: 1990-2006. Asian Economic Journal, 27(3), 285-306.

Figueria, J., Greco, S., \& Ehrgott, M. (2005). Multiple Criteria Decision Analysis: State of The Art Surveys. USA: Springer Science+Business Media, Inc.

Fishburn, P. (1988). Normative Theories of Decision Making under Risk and under Uncertainty. In Bell D. E., Raiffa H., \& Tversky A. (Eds), Decision Making: Descriptive, Normative, and Prescriptive Interactions (p. 78). Cambridge: Cambridge University Press.

Fleurbaey, M., Luchini, S., Muller, C., \& Schokkaert, E. (2013). Equivalent income and the economic evaluation of health care. Health Economics, 22(6), 7I I-729.

Folds, D. J., \& Thompson, V. M. (2013). Engineering Human Capital: A System of Systems Modeling Approach. Proceeding of the 8th International Conference on System of Systems Engineering, (Pp. 285-290). Maui, Hawaii, USA.

Foley, K., \& Hamilton, B. (2006). Using the value measuring methodology to evaluate government initiatives. Proceedings of the 2006 Crystal Ball User Conference, 16.

Fosu, A.K. (2017). Growth, inequality, and poverty reduction in developing countries: Recent global evidence. Research in Economics. 7I(2), 306-336.

Foxon, T., Mcilkenny, G., Gilmour, D., Oltean-Dumbrava, C., Souter, N., Ashley, R., Butler, P., Pearson, P., Jowitt, P. \& Moir, J. (2002). Sustainability Criteria for Decision Support in the UK Water Industry. Journal of Environmental Planning and Management, 45:2, 285-30I.

Franken, I. H., van Strien, J. W., Nijs, I., \& Muris, P. (2008). Impulsivity is associated with behavioral decision-making deficits. Psychiatry Research, I58(2), I55-163.

French, N., \& Gabrielli, L. (2005). Discounted cash flow: accounting for uncertainty. Journal of Property Investment \& Finance, 23(I), 75-89.

Gair, C. (2002). A Report From the Good Ship SROI: The Roberts Enterprise Development Fund. The Roberts Foundation. 
Gamboa, G., \& Munda, G. (2007). The problem of windfarm location: A social multicriteria evaluation framework. Energy Policy, 35, I 564-I 583.

Garmendia, E., Gamboa, G., Franco, J., Garmendia, J. M., Liria, P., \& Olazabal, M. (2010). Social multi-criteria evaluation as a decision support tool for integrated coastal zone management. Ocean \& Coastal Management, 53, 385-403.

Ghasemzadeh, F., \& Archer, N. P. (2000). Project portfolio selection through decision support. Decision Support Systems, 73-88.

Goldstein, W. M., \& Busemeyer, J. R. (1992). The effect of "irrelevant" variables on decision making: Criterion shifts in preferential choice? Organizational Behavior and Human Decision Process, 52(3), 425-454.

Grindle, M.S. (2004). Good enough governance: poverty reduction and reform in developing countries. Governance. 17(4), 525-548.

Handley, D. M., \& Howell-Moroney, M. (2010). Ordering stakeholder relationships and citizen participation: Evidence from the community development block grant program. Public Administrations Review(July/August ), 60I-609.

Harberger, A. C., Jenkins, G. P., \& Kuo, C.-Y. (1997). The economic opportunity cost of capital. In Jenkins G. P. \& Harberger A. C. (Eds), Cost-Benefit Analysis for Investment Decisions. Boston (MA) : Harvard Institute for International Development.

Harrison, E. F. (1995). The managerial decision-making process. Boston, MA: Houghton Mifflin.

Harrison, M. (2010). Valuing the Future: the social discount rate in cost-benefit analysis. Commonwealth of Australia.

Haughton, A. J., Bond, A. J., Lovett, A. A., Dockerty, T., Sünnenberg, G., Clark, S. J., Bohan, D. A., Sage, R. B., Mallott, M. D., Mallott, V. E., Cunningham, M. D., Riche, A. B., Shield, I. F, Finch, J. W., Turner, M. M. \& Karp, A. (2009). A novel, integrated approach to assessing social, economic and environmental implications of changing rural land-use: a case study of perennial biomass crops. Journal of Applied Ecology, 46, 315-322.

Herrera, F., Herrera-Viedma, E., \& Verdegay, J. (1996). A model of consensus in group decision making under linguistic assessments. Fuzzy Sets and Systems, 78, 73-87.

Hogarth, R. M. (1987). Judgment and Choice: The Psychology of Decision. New York: John Wiley \& Sons Inc.

Holloway, C. A. ( 1979). Decision Making under Uncertainty: Models and Choices. New Jersey, USA: Prentice Hall.

Holsapple, C. W. (2008). Decisions and Knowledge. In Burstein F. \& Holsapple C. W. (Eds), Handbook on Decision Support Systems I: Basic Themes. Springer-Verlag Berlin Heidelberg. 
Huang, C-C., Chu, P-Y., \& Chiang, Y-H. (2008). A fuzzy AHP application in government-sponsored R\&D project selection. International Journal of Management Science. OMEGA. 36, I038-1052.

Huang, I. B., Keisler, J., \& Linkov, I. (20I I). Multi-criteria decision analysis in environmental sciences: Ten years of applications and trends. Science of The Total Environment, 409(19), 3578-3594.

Janis, I., \& Mann, L. (1977). Decision Making. New York: The Free Press.

Janssen, R. (200I). On the use of multi-criteria analysis in environmental impact assessment in the Netherlands. Journal of Multi-Criteria Decision Analysis, 10, 101-109.

Jenkins, G. P., Kuo, C.-Y., \& Harberger, A. C. (20II). Discounting and alternative investment criteria. In Jenkins, G. P. \& Harberger, A. C. (Eds), Cost-Benefit Analysis for Investment Decisions.

Jennings, D., \& Wattam, S. (1998). Decision Making: An Integrated Approach. London, UK: Financial Times Pitman Publishing.

Jó, P. A., \& Barry, M.-L. (2008). The Most Important Success Factors for Implementation of Government Projects in Developing Countries. PICMET 2008 Proceedings, 27-3I July, (pp. I400-1409). Cape Town, South Africa.

Kabassi, K., \& Virvou, M. (2004). Personalised adult e-training on computer use based on multiple attribute decision making. Interacting with Computers, 16, II5-132.

Kabli, M. R. (2009). A Multi-Attribute Decision Making Methodology for Selecting New R\&D Projects Portfolio with A Case Study of Saudi Oil Refining Industry. Thesis of the University of Nottingham.

Kahneman, D., \& Tversky, A. (1972). Subjective probability: A judgment of representativeness. Cognitive Psychology, 3, 430-454.

Kahneman, D., \& Tversky, A. (1973). On the psychology of prediction. Psychological Review, 80(4), 237-25I.

Kassouf, S. T. (1970). Normative Decision Making. USA: Prentice Hall.

Keeney, R. L. (1992). Value-focused thinking: A path to creative decisionmaking. Cambridge (MA): Harvard University Press.

Keeney, R. L. (1996). Value-focused thinking: Identifying decision opportunities and creating alternatives. European Journal of Operational Research, 92, 537-549.

Klakegg, O. J. (2009). Pursuing relevance and sustainability: Improvement strategies for major public projects. International Journal of Managing Projects in Business, 2(4), 499-5I8.

Krueathep, W. (2004). Local Government Initiatives in Thailand: Cases and Lessons Learned. Asia Pacific Journal of Public Administration, 26, 21 7-239. 
Krueathep, W. (2008). Collaborative Network Activities of Thai Subnational Governments: Current Practices and Future Challenges. International Public Management Review, 9(2), 15-38.

Lateef-Ur-Rehman, A.-U.-R. (20I3). Manufacturing configuration selection using multicriteria decision tool. The International Journal of Advanced Manufacturing Technology, 65, 625-639.

Lech, K., \& Sussman, D. (20I I). Investment project design: a guide to financial and economic analysis with constraints (Vol. 632). John Wiley \& Sons.

Lee Jr., D. (2000). Methods for evaluation of transportation projects in the USA. Transport Policy, 7, 4I-50.

Levy, H., \& Sarnat, M. (1995). Capital Investment \& Financial Decision (5th ed.). Englewood Cliffs (NJ): Prentice-Hall.

Little, I., \& Mirrlees, J. (1974). Project appraisal and planning for developing countries. London, UK: Heinemann Educational Books.

Liu, J., Derzsi, Z., Raus, M., \& Kipp, A. (2008). eGovernment Project Evaluation: An Integrated Framework. In Wimmer, M., Scholl, H. \& Ferro, E. (Eds), Electronic Government (pp. 85-97). Berlin Heidelberg: Springer-Verlag.

Lopez, H. (2008). The Social Discount Rate: Estimates for Nine Latin American Countries. The World Bank.

Lorsuwannarat, T., \& Buracom, P. (20I I). Performance Management Reforms in Thailand. In Berman, E. M. (Ed), Public Administration in Southeast Asia: Thailand, Philippines, Malaysia, Hong Kong, and Macao (pp. 95-I I 2). the United States of America: Taylor and Francis Group, LLC.

Lumby, S. (199I). Investment Appraisal and Financing Decisions (4th ed.). London, UK: Chapman and Hall.

Lyons, M. (2009). Building Back Better: The Large-Scale Impact of Small-Scale Approaches to Reconstruction. World Development, 37(2), 385-398.

Mahmoodzadeh, S., Shahrabi, J., Pariazar, M., \& Zaeri, M. (2007). Project selection by using fuzzy AHP and TOPSIS technique. International Journal of Industrial and Manufacturing Engineering, I, no.6, 270-275.

Maneepong, C., \& Webster, D. (2008). Governance responses to emerging periurbanisation issues at the global-local nexus: The case of Ayutthaya, Thailand. International Development Planning Review, 30(2), I33-I54.

Massam, B. H. (1999). The classification of quality of life using multi-criteria analysis. Journal of Geographic Information and Decision Analysis, 3, I-8.

Mawdesley, M., Hernandez, O., \& Al-jibouri, S. (2005). A decision making model for infrastructure projects selections in developing countries. Journal of Financial Management of Property and Construction, 10, I35-I 46. 
Medaglia, A. L., Hueth, D., Mendieta, J. C., \& Sefair, J. A. (2008). A multiobjective model for the selection and timing of public enterprise projects. Socio-Economic Planning Sciences, 42, 31-45.

Memariani, A., Amini, A., \& Alinezhad, A. (2009). Sensitivity Analysis of Simple Additive Weighting Method (SAW): The Results of Change in the Weight of One Attribute on the Final Ranking of Alternatives. Journal of Industrial Engineering, 4, 13-18.

Mendoza, G., \& Martins, H. (2006). Multi-criteria decision analysis in natural resource management: A critical review of methods and new modelling paradigms. Forest Ecology and Management, 230, I-22.

Meredith, J. R., \& Mantel, S. J. (2010). Project Management: A Managerial Approach (7th ed.). NewYork: Wiley.

Millar, A. (1988). Selecting capital investment projects for local governments. Public Budgeting \& Finance, 8(3), 63-77.

Mintzberg, H., Raisinghani, D., \& Theoret, A. (1976). The structure of unstructured decision processes. Administrative Science Quarterly, 2 I (2), 246-275.

Mishan, E. (1982). Introduction to Political Economy. London, UK: Hutchinson \& Co.

Mishan, E., \& Quah, E. (2007). Cost-benefit analysis (5th ed.). USA: Routledge.

Miyao, R. (2000). The role of monetary policy in Japan: A break in the 1990s? Journal of the Japanese and International Economies, 14, 366-384.

Montgomery, H. (1983). Decision rules and the search for a dominance structure: Towards a process model of decision making. Advance in Psychology, 14, 343369.

Montis, A. d., Toro, P. D., Droste-Franke, B., Omann, I., \& Stagl, S. (2005). Assessing the quality of different MCDA methods. In M. Getzner, C. L. Spash, \& S. Stagl (Eds.), Alternatives for Environmental Evaluation. Routledge.

Mulder, K. (Ed.). (2006). Sustainable development for engineers: A handbook and resource guide. Sheffield, UK: Greenleaf.

Munda, G. (2004). Social multi-criteria evaluation: Methodological foundations and operation consequences. European Journal of Operational Research, 158, 662677.

Munda, G. (2008). Social Multi-Criteria Evaluation for a Sustainable Economy. SpringerVerlag Berlin Heidelberg.

Nadeem, O., \& Fischer, T. B. (20II). An evaluation framework for effective public participation in EIA in Pakistan. Environmental Impact Assessment Review, 31 , 3647.

Narayan, D. (1996). Learning from the poor : poverty, participation and the environment. Environment matters : at the World Bank, Summer, 16-19. 
National Statistical Office Thailand. (2006). http://www.nso.go.th/sites/20 /4/Pages/e-Book. Retrieved from http://www.nso.go.th/

Ness, B., Urbel-Piirsalu, E., Anderberg, S., \& Olsson, L. (2007). Categorising tools for sustainability assessment. Ecological Economics. 60, 498-508.

OECD. (20I0). DAC Guidelines and Reference Series: Quality Standards for Development Evaluation. Development Assistance Committee. OECD.

O'Faircheallaigh, C. (2010). Public participation and environmental impact assessment: Purposes, implications, and lessons for public policy making. Environmental Impact Assessment Review, 30, 19-27.

Ogola, P. F. (2007). Environmental impact assessment general procedures. Presented at Short Course II on Surface Exploration for Geothermal Resources. at Lake Naivasha, Kenya, 2-I7 November: UNU-GTP and KenGen.

Oishi, S., Diener, E. F., Lucas, R. E., \& Suh, E. M. (1999). Cross-cultural variations in predictors of life satisfaction: Perspectives from needs and values. Personality and Social Psychology Bulletin, 25(8), 980-990.

Olson, D. L. (2008). Multi-Criteria Decision Support. In Burstein, F. \& Holsapple, C. W. (Eds.), Handbook on Decision Support Systems I: Basic Themes, Berlin Heidelberg: Springer-Verlag.

ONEP. (2004a). Public hearing document on the improvement of national EIA system. Thailand: Office of natural resources and environmental policy and planning.

Osborne, M. J. (20I0). A resolution to the NPV-IRR debate? The Quarterly Review of Economics and Finance, 50, 234-239.

Park, H. K., Han, S. H., \& Russell, J. S. (2005). Cash flow forecasting model for general contractors using moving weights of cost categories. Journal of Management in Engineering, 164-172.

Pavličić, D. M. (200I). Normalisation affects the results of MADM methods. Yugoslav Journal of Operations Research, II, 254-265.

Payne, J. W., Bettman, J., \& Johnson, E. (1993). The adaptive decision maker. Cambridge University Press.

Pearce, D., Atkinson, G., \& Mourato, S. (2006). Cost-Benefit Analysis and the Environment: Recent Development. OECD.

Peffers, K., Tuunanen, T., Rothenberger, M. A., \& Chatterjee, S. (2008). A design science research methodology for information systems research. Journal of Management Information Systems, 24(3), 45-78.

Pike, R., \& Neale, B. (2006). Corporate Finance and Investment: Decision \& Strategies. Pearson Education.

Polatidis, H., Haralambopoulos, D. A., Munda, G., \& Vreeker, R. (2006). Selecting an appropriate multi-criteria decision analysis technique for renewable energy planning. Energy Sources, Part B: Economics, Planning, and Policy, I (2), I8I-I93. 
Raftery, J. (1998). From Ptolemy to Heisenberg: quantitative models and reality. Construction Management \& Economics, I6(3), 295-302.

Rajaram, A., Le, T. M., Biletska, N., \& Brumby, J. (20 I0). A Diagnostic Framework for Assessing Public Investment Management. Policy Research working paper ; no. WPS 5397. World Bank.

Ramanathan, R. (200I). A note on the use of the analytic hierarchy process for environmental impact assessment. Journal of Environmental Management, 63, 27 35 .

Ravlin, E. C., \& Meglino, B. M. (1987). Effect of values on perception and decision making: A study of alternative work values measures. Journal of Applied Psychology, 72, 666-673.

Raymond, C. M., Bryan, B. A., MacDonald, D. H., Cast, A., Strathearn, S., Grandgirard, A., \& Kalivas, T. (2009). Mapping community values for natural capital and ecosystem services. Ecological Economics, 68, I30I-1315.

Reardon, T., \& Vosti, S. A. (1995). Links Between Rural Poverty and the Environment in Developing Countries: Asset Categories and Investment Poverty. World Development, 23(9), I495-I506.

Reed, M. S. (2008). Stakeholder participation for environmental management: A literature review. Biological Conservation, I4I(10), 24I7-243I.

Reed, M. S., Fraser, E. D., \& Dougill, A. J. (2006). An adaptive learning process for developing and applying sustainability indicators with local communities. Ecological Economics, 59, 406-4I8.

Reiter, S. (1963). Choosing an investment program among interdependent projects. The Review of Economic Studies, 30(I), 32-36.

Remer, D., \& Nieto, A. (1995). A compendium and comparison of 25 project evaluation techniques. Part I: Net present value and rate of return methods. International journal of production economics, 42(I), 79-96.

Saaty, T.L. (1990). How to make a decision: The Analytic Hierarchy Process. European Journal of Operational Research. 48, 9-26.

Salgado, P. P., Quintana, S. C., Pereira, Â. G., Ituarte, L. d., \& Mateos, B. P. (2009). Participative multi-criteria analysis for the evaluation of water governance alternatives. A case in the Costa del Sol (Málaga). Ecological Economics, 68, 9901005.

Sanders, G. D., Neumann, P. J., Basu, A., Brock, D. W., Feeny, D., Krahn, M., Kuntz, K. M., Meltzer, D. O., Owens, D. O., Prosser, L. A., Salomon, J. A., Sculpher, M. J., Trikalinos, T. A., Russel, L. B., Siegel, J. E. \& Ganiats, T. G. (2016). Recommendations for conduct, methodological practices, and reporting of cost-effectiveness analyses: Second panel on cost-effectiveness in health and medicine. Clinical Review \& Education, 3 / 6, I093-I 103.

Scarborough, H., \& Bennett, J. (2008). Estimation intergenerational distribution preferences. Ecological Economics, 66(4), 575-583. 
Schniederjans, M. J., Hamaker, J. L., \& Schniederjans, A. M. (2004). Information Technology Investment: Decision-Making Methodology. World Scientific Publishing Company.

Scott, L. (2005). Participatory multi-criteria decision analysis: a new tool for integrated development planning. Development Southern Africa. 22(5), 695-7I6.

Shaner, W. (1979). Project planning for developing economies. New York: Praeger Publishers.

Shiferaw, A. T., Klakegg, O. J., \& Haavaldsen, T. (2012). Governance of Public Investment Projects in Ethiopia. Porject Management Journal, 43, No. 4, 52-69.

Silva, V. B., Morais, D. C., \& Almeida, A. T. (2010). A Multicriteria Group Decision Model to Support Watershed Committees in Brazil. Water Resource Management, 24(14), 4075-409l.

Simon, H. (1960). The new science of management decision. New York: Harper and Row.

Simon, H. A. (1955). A behavioral model of rational choice. The Quarterly Journal of Economics, 69(I), 99-II8.

Srithongrung, A. (2009). The Effects of Results-Oriented Budgeting on Government Spending Patterns in Thailand. International Public Management Review, IO(I), 59-89.

Tang, J.C, \& Phataralaoha, Y. (1987). Project appraisal for developing countries: A systematic approach. Socio-Economic Planning Sciences. 2 I (6), 377-387.

Tanzi, V., \& Davoodi, H. (200I). Corruption, growth, and public finances. In Jain, A. K. (Ed), The Political Economy of Corruption (pp. 89-100). London and New York: Routledge.

TEl. (2005). Thailand's state of environmental governance report 2005 (2nd assessment). Thailand: Thailand Environment Institute.

The Bureau of the Budget. (20II). Monitoring Manual. Bangkok.

The WHOQOL Group. (1995). The World Health Organization quality of life assessment (WHOQOL): Position paper from the World Health Organization. Social Science \& Medicine, 4I (10), I 403-I409.

The World Bank. (1994). Operational Manual - Operational Policies. Washington DC, USA: The World Bank.

Todaro, M. P., \& Smith, S. C. (20I5). Economic Development (I 2th ed.). USA: Pearson.

Topal, E. (2008). Evaluation of a mining project using Discounted Cash Flow analysis, Decision Tree analysis, Monte Carlo Simulation and Real Options using an example. Internation Journal of Mining and Mineral Engineering, I, 62-76.

Tsamboulas, D. A. (2007). A tool for prioritizing multinational transport infrastructure investments. Transport Policy, I4, I I-26.

Tversky, A. (1972). Elimination by aspects: A theory of choice. Psychological Review, 79(4), 28I-299. 
Tversky, A. (2003). Elimination by aspects: A theory of choice. Preference, Belief, and Similarity: selected writings, 463-492.

United Nations Development Programme. (2000). Human Development Report. New York: Oxford University Press.

Veenhoven, R. (199I). Is happiness relative? Social Indicators Research, 24, I-34.

Velnampy, T. (2005). A study on investment appraisal and profitability. Journal of Business Studies, 2(I), 23-35.

Vichit-Vadakan, J. (20I I). Public ethics and corruption in Thailand. In Berman, E. M. (Ed), Public administration in Southeast Asia: Thailand, Philippines, Malaysia, Hong Kong, and Macao (pp. 79-94). London, New York: CRC Press.

Walshe, G., \& Daffern, P. (1990). Managing Cost Benefit Analysis. London: Macmillan.

Wang, Y., \& Wang Y. (2004). Cognitive formatics models of the brain. IEEE Transactions on Systems, Man, and Cybernetics, 36(2), 203-207.

Wang, Y.-J. (20I5). A fuzzy multi-criteria decision-making model based on simple additive weighting method and relative preference relation. Applied Soft Computing, 30, 4I 2-420.

Wetekamp, W. (20II). Net present value (NPV) as a tool supporting effective project management. The 6th IEEE International Conference on Intelligent Data Acquisition and Advanced Computing Systems: Technology and Applications, I5-I 7 September, (pp. 898-900). Prague, Czech Republic.

Widianta, M. M., Rizaldi, T., Setyohadi, D. P., \& Riskiawan, H. Y. (20 I8). Comparison of multi-criteria decision support methods (AHP, TOPSIS, SAW \&

PROMENTHEE) for employee placement. Journal of Physics: Conference Series, 953.

Wieringa, R. J. (20I4). Design Science Methodology for Information Systems and Software Engineering. Springer-Verlag Berlin Heidelberg.

Wilburn, K.M. \& Wilburn, R. (20II). Achieving social license to operate using stakeholder theory. Journal of International Business Ethics. 4, 3-16.

Wirutskulshai, U., Sajor, E., \& Coowanitwong, N. (20I I). Importance of context in adoption and progress in application of strategic environmental assessment: Experience of Thailand. Environmental Impact Assessment Review, 3I, 352-359.

Witte, E., Joost, N., \& Thimm, A. L. (1972). Field research on complex decision-making processes-the phase theorem. International Studies of Management \& Organization, 2.2, 156-182.

World Bank. (20I2). Identifying the constraints to budget execution in the infrastructure sector: DIPA tracking study. Washington, DC: World Bank.

Yard, S. (2000). Developments of the payback method. International Journal of Production Economics, 67, I55-167. 
Yoe, C. (2002). Trade-off analysis planning and procedures guidebook. Alexandria (VA):

U.S. Army Corps of Engineers Institute for Water Resources.

Yoon, K., \& Hwang, C.-L. (1995). Multiple Attribute Decision Making: An Introduction. Sage Publications.

Zeelenberg, M. (1999). Anticipated regret, expected feedback and behavioral decision making. Journal of Behavioral Decision Making, 12, 93-106.

Zimmermann, H. (20I2). Fuzzy sets, decision making, and expert systems (Vol. 10). Springer Science \& Business Media.

Zuhair, M. H., \& Kurian, P. A. (2016). Socio-economic and political barriers to public participation in EIA: implications for sustainable development in the Maldives. Impact Assessment and Project Appraisal, 34(2), I29-I 42. 
$226 \mid$ 


\section{Acknowledgement}

Before coming to the Netherlands, someone once told me that achieving a doctorate degree does not mean that you are smarter. It just proves that you are a person who is very tolerant of stress and challenges. I couldn't agree more. My research had undergone various levels of joy, friendships, tests and trials, tears and disappointments. But I was lucky that I had the support of good friends and family around me.

There are countless individuals to thank, but the first goes to Joop for replying to my email from Thailand and giving me an opportunity to start my journey at the University of Twente. We had a short interview on Skype showing me around the aquarium (the previous office), which was empty and quiet on a Saturday. Since the first day we talked until the last stage of my work, I can sincerely say that Joop exemplifies the true definition of a teacher. He has a kind heart who has always been advocate to his students. I have learned a lot from Joop in the scope of academia. Joop is a worker bee whose thirst for knowledge continues to inspire his students, even on the weekends. I often wake up in the morning and see his emails come through on a Saturday or Sunday.

Next comes to Saad, my daily supervisor. Without him, I could not finish my work in time and would not have my degree. Saad, is like my second dad. He trained me patiently on how to be a researcher and taught me the importance of technical details. With my zero level of research skills, I almost gave up many times, but Saad always reinforced in me why I started this journey in the first place. Saad never gave up on me. He helped me with everything and gave me his moral support even during his retirement.

Years of working would be tedious without the company of good friends and colleagues. A million thanks goes out to previous and current colleagues at the Department of Construction Management and Engineering (CME) for their warm welcome and for sharing good and bad stories of their lives and work. A special thanks to Ruth, Marc, Denis, Camilo and Michiel for being my first friends at CME. We had several nice trips and many fun talks together, showcasing our support to each other. I also would like to give my gratitude to my big sister, Ria. She was the first landlord I stayed with and was the first Dutch person I have personally met. She provided plenty of tips about being Dutch, like cooking stamppot, eating cheese with cold bread, making perfect tea, washing dishes in 
a Dutch way. Ria and I still keep in touch like family. I cherish all these precious and unforgettable moments in the Netherlands

More importantly, I would like to thank Michael for his support, for taking care of me and still being with me during the most difficult time in my life. He is only one person that I can truly share my happiness or distress with. Without him, I could not be happier. I also want to thank his family for their warm support and kindness. Our family time keeps on growing.

This research is fully supported by the Royal Thai Government Scholarship, Hydro-Informatics Institute and Ministry of Science and Technology in Thailand. I would like to give my big gratitude to all the people supporting my work and funding, as well as their helpful suggestions throughout the entire period of pursuing my Ph.D.

To this end, a big thanks goes to Wikkie Kruasophon from New York and her friends, Brian Simpson and Joanna de la Rosa, for correcting English in this section and the royal speech in the preface. Thanks to Marc van den Berg for the summary in Dutch (Samenvatting).

ขอขอบพระคุณ อ.รอยล สำหรับโอกาสและทุนการศึกษา รวมถึงประสบการณ์การทำงานที่ หลากหลายท้าทายที่มีประโยชน์อย่างมากต่องานวิจัยฉบับนี้ และขอขอบพระคุณผู้บริหารสถาบัน สารสนเทศทรัพยากรน้ำ (สสน.) ทุกท่าน ที่สนับสนุนการศึกษามาโดยตลอดโดยเฉพาะ อ.สุทัศน์, ดร.รอยบุญ, ดร.สุรเจตน์ และขอขอบคุณเป็นพิเศษสำหรับพี่แป๋ม (คุณจารุมน) สำหรับความเป็น ครูภาษาอังกฤษโดยจำเป็นในช่วงเตรียมตัว และกำลังใจ (พร้อมแรงกดดัน) ตลอดการศึกษา

ขอขอบพระคุณผู้บริหารและเจ้าหน้าที่หน่วยงานราชการต่าง ๆ ที่ให้ความร่วมมือในการอนุเคราะห์ ความคิดเห็น โดยเฉพาะอย่างยิ่ง กรมชลประทาน และ กรมทางหลวง ที่อนุเคราะห์ข้อมูลโครงการ เพื่อนำมาใช้ทดสอบแบบจำลอง

ความสำเร็จนี้ จะไม่สามารถเกิดขึ้นได้หากปราศจากพื้นฐานที่ดี ขอขอบพระคุณครูบาอาจารย์ทุก ๆ ท่าน ในทุกระดับการศึกษาสำหรับความรู้ต่าง ๆ ที่เคยคิดว่าอาจจะไม่ได้ใช้แล้ว แต่สุดท้ายกลับมี ประโยชน์อย่างมากในงานวิจัย และที่สำคัญนี้ อยากขอขอบพระคุณ อ.โชติชัย (AIT) สำหรับวิชา Project management ในระดับปริญญาโท ที่สร้างแรงบันดาลใจในการก้าวเข้ามาสูสายงานนี้ รวมถึงคอนเนคชั่นที่ได้ระหว่างงานวิจัย และความช่วยเหลือต่าง ๆ จนกระทั่งจบการศึกษา

ขอบคุณเพื่อนๆ เตรียมอุดมฯ เล้ง หมวย แบงค์ โน้ต ปุ๊กกี้ เอ็ม ในพื้นที่กรุ๊บไลน์เล็กๆ ที่ได้แชร์ ความเศร้า ความดีใจ และกำลังใจต่างๆ โดยเฉพาะ เจ๊กัล ที่คอยสงข้าวปลาอาหารมาให้ยังชีพ 
อย่างไม่ขาดสาย ซึ้งน้ำใจเพื่อนจริงๆ และขอบคุณชาวนักเรียนไทยเอ็นซะเคเด้ เอ็ม เหมียว สุท เตย พลอย วา สแตน ชัย นัด เมย์ กอล์ฟ สิตี สำหรับความช่วยเหลือเกื้อกูล เม้ามอย และความ สนุกสนานอิ่มท้อง ขอบคุณต๋อม เพื่อนไทยวาเกน สำหรับมิตรภาพ การเดินทาง เพื่อนช้อป และ ความเป็นนางฟ้าของเธอตลอดมา ขอให้ผลบุญสงให้เพื่อนเรียนจบโดยเร็วเช่นกัน ขอบคุณพี่ รถยนต์ สำหรับการเป็นพี่ชายที่แสนดี ที่ช่วยเหลือตั้งแต่เริ่มสมัครเรียน จนจบการศึกษา ขอบคุณเพื่อนๆที่รัก และพี่น้องเพื่อนร่วมงานทุกคนที่ไทย สำหรับความคิดถึง กำลังใจ และ ข้อความถามไถ่สารทุกข์สุกดิบให้หายเหงา

สุดท้ายนี้ ที่สำคัญที่สุดคือ ขอขอบคุณครอบครัว พ่อ แม่ เพชร สำหรับแรงใจที่สำคัญ โดยเฉพาะ -แม่ - ที่ไม่เคยขาดความเชื่อมั่นในตัวลูกสาวเลย กำลังใจและคำชื่นชมจากครอบครัว มี ความสำคัญมากจริง ๆ ต่อความสำเร็จในครั้งนี้

ขอบพระคุณมาก ๆ ค่ะ

พิณทิพย์ วัชโรทัย

มิถุนายน 2562 
230 


\section{About the author}

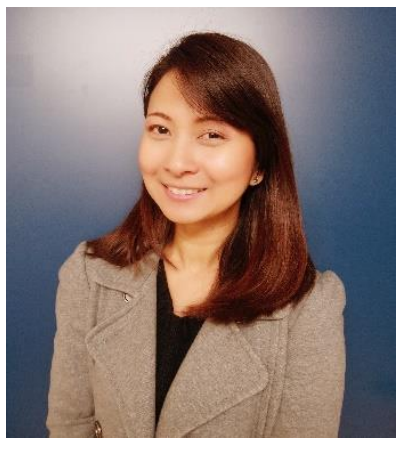

Pintip Vajarothai was born on $22^{\text {nd }}$ of August in Bangkok, Thailand. In her hometown, Pintip studied Visual Communication Arts at Silpakorn University. After her graduation, she had the opportunity to start her first career as a UI/UX designer for various government projects where she learned how a public project is arranged and proceed to the implementation. In 2008, she received her M.Sc. in Technology Management at Thammasat University and she found her most interest lie in the fields of project management and evaluation, and resource and budget planning. Project management has become her profession at Hydro-Informatics Institute (HII), Ministry of Science and Technology, where she built up experience in managing and dealing with many major and local public projects concerning research and development, publicprivate partnership and cooperation with local communities. After eight years at HII, she got a scholarship from the Royal Thai Government to pursue a doctorate program at University of Twente in the Netherlands (2015-2019). Her research was about exploring theory and practice to improve the evaluation and selection process for public investment projects. She used Thailand as a case study and developed an integrated decision model in order to assist decision makers to select the most suitable alternative project. With this achievement, her current intentions are aimed to share her knowledge and to encourage relevant government authorities in Thailand to practically implement her decision model for their investment selection. 